\title{
Exploring the climate change refugia potential of equatorial Pacific coral reefs
}

\author{
by \\ Elizabeth Joan Drenkard \\ B.A., Cornell University, 2009 \\ Submitted in partial fulfillment of the requirements for the degree of \\ Doctor of Philosophy \\ at the \\ MASSACHUSETTS INSTITUTE OF TECHNOLOGY \\ and the \\ WOODS HOLE OCEANOGRAPHIC INSTITUTION
}

February 2015

(C) Elizabeth Joan Drenkard, 2015. All rights reserved.

The author hereby grants to MIT and to WHOI permission to reproduce and distribute publicly paper and electronic copies of this thesis document in whole or in part in any medium now known or hereafter created.

Author

Joint Program in Oceanography/ Applied Ocean Science and Engineering

Massachusetts Institute of Technology and Woods Hole Oceanographic Institution

October 3, 2014

Certified by

Anne L. Cohen

Associate Scientist, Department of Geology and Geophysics, WHOI

Thesis Co-Supervisor

Certified by

Daniel C. McCorkle

Senior Scientist, Department of Geology and Geophysics, WHOI

Thesis Co-Supervisor

Certified by

Kristopher B. Karnauskas

Associate Scientist, Department of Geology and Geophysics, WHOI

Thesis Co-Supervisor

Accepted by

Timothy L. Grove

Professor of Earth, Atmospheric, and Planetary Sciences, MIT Chairman, Joint Committee for Marine Geology and Geophysics 


\title{
Exploring the climate change refugia potential of equatorial Pacific coral reefs
}

\author{
by \\ Elizabeth Joan Drenkard
}

Submitted to the Joint Program in Oceanography/Applied Ocean Science and Engineering Massachusetts Institute of Technology/Woods Hole Oceanographic Institution on October 3, 2014, in partial fulfillment of the requirements for the degree of Doctor of Philosophy

\begin{abstract}
Global climate models project a 21st century strengthening of the Pacific Equatorial Undercurrent (EUC). The consequent increase in topographic upwelling of cool waters onto equatorial coral reef islands would mitigate warming locally and modulate the intensity of coral bleaching. However, EUC water is potentially more acidic and richer in dissolved inorganic nutrients (DIN), both widely considered detrimental to coral reef health.

My analysis of the Simple Ocean Data Assimilation product indicates that the EUC has indeed strengthened over the past 130 years. This result provides an historical baseline and dynamical reference for future intensification. Additionally, I reared corals in laboratory experiments, co-manipulating food, light and $\mathrm{CO}_{2}$ (acidity) to test the role of nutrition in coral response to elevate $\mathrm{CO}_{2}$ conditions. Heterotrophy yields larger corals but $\mathrm{CO}_{2}$ sensitivity is independent of feeding. Conversely, factors that enhance zooxanthellate photosynthesis (light and DIN) reduce $\mathrm{CO}_{2}$ sensitivity. Corals under higher light also store more lipid but these reserves are not utilized to maintain calcification under elevated $\mathrm{CO}_{2}$. My results suggest that while mitigation of $\mathrm{CO}_{2}$ effects on calcification is not linked to energetic reserve, EUC fueled increases in DIN and productivity could reduce effects of elevated $\mathrm{CO}_{2}$ on coral calcification.
\end{abstract}

Thesis Co-Supervisor: Anne L. Cohen

Title: Associate Scientist, Department of Geology and Geophysics, WHOI

Thesis Co-Supervisor: Daniel C. McCorkle

Title: Senior Scientist, Department of Geology and Geophysics, WHOI

Thesis Co-Supervisor: Kristopher B. Karnauskas

Title: Associate Scientist, Department of Geology and Geophysics, WHOI 


\section{Acknowledgments}

I thank my advisors Drs. Anne Cohen, Daniel McCorkle, and Kristopher Karnauskas for their support and guidance throughout my graduate studies and for the opportunity to pursue such an interdisciplinary and fascinating research topic. Their mentorship, tutelage, and passion for oceanography have molded and inspired the direction of my scientific career.

I am also grateful to my thesis committee members, Drs. Janelle Thompson, Russell Brainard, committee chair, Dr. Delia Oppo and Generals advisor Dr. Sarah Cooley for their time and insights; their diverse perspectives and backgrounds have enriched my dissertation research. The contributions of my coauthors and collaborators Drs. Samantha dePutron, Vicke Starczak, Dan Repeta, and Ms. Alice Zicht have been essential to my experimental studies

The scientific and technical assistance of Ed O'Brien, Rebecca Belastock, Elizabeth Bonk, Paul Henderson, Dave Wellwood and Julie Arruda have been invaluable to my fieldwork preparations, and data generation and analyses. I greatly appreciated the WHOI Academic Programs Office and the MIT Academics Office for their endless help and support. Thanks also to the Geology and Geophysics department administrators, WHOI facilities staff, and the staff and interns at the Bermuda Institute of Ocean Sciences, especially Kascia White, who helped make my ocean acidification experiments a success.

Many thanks to the crew of the Sea Dragon, Captain Dale Selvam, Emily Penn, Ryan McInerney, and Alec Nordschow for a safe and successful expedition through the central Pacific and to Chip Young and Kelsie Ernsberger for sharing their knowledge of and respect for the exquisite ecosystems found on remote equatorial Pacific islands.

To the Cohen Lab family: Pat Lohmann, Kathryn Rose Pietro, Neal Cantin, Katie and One Shamberger, Michael Holcomb, Casey Saenger, Sara Bosshart, Hannah Barkley, Alice Alpert, Tom DeCarlo, Hanny Rivera, and Angela Helbling. Thank you for the scientific (and non-scientific) discussions, research assistance and camaraderie; it has always been an adventure.

I am grateful to my friends and fellow JP students for being at the core of my life on the Cape, especially Britta for enduring my antics and idiosyncrasies over the past four years. Also, many thanks to Alec, Elise, Mary, Kalina and Meagan for being amazing friends, especially during these last few months. Thanks also to Captain John Cartner for teaching me how to catch a lobster and the Friends of Falmouth Dogs for being a regular source of humanity; both have helped me maintain perspective and a positive attitude.

My family has been a perpetual source of encouragement and inspiration, in particular my grandmothers, Joan and Margot - two of the strongest, most stubborn and courageous women I have even known and from whom I have clearly inherited a passion for the ocean, music and chocolate. Finally, my parents, Hans and Diane, have been my rock these past five years and beyond. Their moral support, good humor, and sound advice have helped me navigate even the most difficult times and it is to them I dedicate this thesis.

Funding for this research was provided by NSF grants OCE-1220529, OCE-1041106, OCE-1031971, OCE-1233282, and OCE-1041052; the MIT Bermuda Biological Research Station Fund, the WHOI Oceans Venture Fund, and the EAPS Student Research Fund. Travel to meetings and conferences to present these results, was supported by grants from WHOI, MIT, and the MIT Graduate Student Council. 


\section{Contents}

1 Introduction $\quad 9$

2 Strengthening of the Pacific Equatorial Undercurrent in the SODA Reanalysis: Mechanisms, Ocean Dynamics, and Implications

3 Calcification by juvenile corals under heterotrophy and elevated $\mathrm{CO}_{2}$

4 Calcification by juvenile corals under varied light and elevated $\mathrm{CO}_{2}$

5 Conclusions

Appendix A Data for Chapter 3

Appendix B Data for Chapter 4

Appendix C Data for Chapter 5 


\section{Chapter 1}

\section{Introduction}

\subsection{Climate Change Overview}

Anthropogenic climate change and associated ocean impacts jeopardize marine species and ecosystems, including important living marine resources. Of these resources, coral reefs, which provide billions of dollars in ecosystem services annually to hundreds of millions of people worldwide (Moberg \& Folke 1999, Cesar et al. 2003), are often considered the proverbial "canary in the coal mine" for climate change, due to their sensitivity to $\mathrm{CO}_{2}$ driven changes in ocean temperature and $\mathrm{pH}$ (acidification; Hughes et al. 2003). The goal of my research is to investigate how these changes affect oceanic and environmental conditions on specific reef ecosystems, and explore the response of reef-building corals to resultant co-varying factors in order to better anticipate their viability under projected climate and ocean change.

Since the industrial revolution (mid- $18^{\text {th }}$ century), human combustion of fossil fuels (i.e., coal, oil, and natural gas) and deforestation have accelerated the flux of carbon dioxide $\left(\mathrm{CO}_{2}\right)$ to the atmosphere (Keeling 1973, van der Werf et al. 2009). This shift in global carbon cycling has caused a dramatic and measurable increase in atmospheric $\mathrm{CO}_{2}$ concentration ( $>43 \%$ as of August 2014, relative to $\sim 278$ ppm in 1750; e.g., Keeling et al. 1976, Neftel et al. 1985, Friedli et al. 1986, Etheridge et al. 1996, Tans \& Keeling 2014).

Anthropogenic $\mathrm{CO}_{2}$ emissions and the warming of Earth's surface are linked. Earth's surface absorbs incoming shortwave radiation from the sun and reemits it as outgoing longwave radiation toward space. Greenhouse gases (GHGs), including $\mathrm{CO}_{2}$, are not transparent to longwave radiation and absorb and reemit a large proportion (approximately 90\%) of the energy radiated from Earth's surface in approximate proportion to their temperature (i.e., Stefan-Boltzmann law; Trenberth et al. 2009). Since the temperature of the atmosphere is lower than at the surface, the energy reemitted by $\mathrm{CO}_{2}$ is less than the energy absorbed

and, by conservation of energy, leads to an increase in atmospheric temperature. As the concentration of GHGs in the atmosphere increases, the overall emission temperature (and 
thus the amount of energy emitted to space) decreases. This net radiative imbalance determines the rate at which the temperature of the surface and atmosphere rise. The transfer of heat between the atmosphere and ocean is determined in part by the thermal gradient across the air-sea interface. Warming of the lower atmosphere results in an increased heat flux into the surface ocean and thus contributes to ocean warming.

Global warming is expected to influence the circulation of the atmosphere and the ocean, the water cycle, and to stimulate complex feedbacks (e.g., reduced ice cover and planetary albedo, increased release of GHG due to permafrost thawing; Collins et al. 2013). In order to understand and anticipate such repercussions, considerable effort has been dedicated to the development of global coupled general circulation models (GCMs) and Earth System Models (ESMs). Such models numerically simulate the thermodynamics, fluid dynamics and in some cases the interactive chemical and biogeochemical processes occurring within and across all realms of the Earth system under prescribed scenarios of atmospheric GHG concentrations. The Climate Model Intercomparison Project (CMIP) was established in 1995 to evaluate and compare results from similarly-forced simulations from models that were developed by different international organizations, and to facilitate data availability to the scientific community (Covey et al. 2003). CMIP is currently in its fifth phase (CMIP5) and uses "representative concentration pathway" (RCPs) that describe specific $\mathrm{CO}_{2}$ forcing trajectories that are numerically identified by end-of-century level of radiative forcing (e.g., under the high emission scenario RPC 8.5, radiative forcing in 2100 reaches $8.5 \mathrm{~W} \mathrm{~m}^{-2}$; Taylor et al. 2012). CMIP5 models predict an increase of as much $4.8^{\circ} \mathrm{C}$ in global average temperature by the end of this century (upper RCP 8.5 projections for 2081-2100 relative to 1986-2005 mean; synthesized in Collins et al. 2013).

Thermal and chemical $\mathrm{CO}_{2}$-forcing also impact ocean biogeochemistry. Increased water column stratification (as a result of higher sea surface temperatures; SST) and consequently, reduced upwelling of dissolved inorganic nutrients (DIN) from depth, is expected to impact surface ocean phytoplankton productivity (Behrenfeld et al. 2006). Additionally, ocean absorption of $\mathrm{CO}_{2}$ has increased proportionally with atmospheric concentration (summarized in Doney et al. 2009, Fig. 1). Upon entering the ocean, $\mathrm{CO}_{2}$ reacts with water to form carbonic acid, which in turn dissociates to bicarbonate and hydrogen ions, resulting in an overall reduction in ocean $\mathrm{pH}$ or ocean acidification $(\mathrm{OA})$. This process shifts the balance 
of dissolved inorganic carbon (DIC) species, thus reducing the concentration of carbonate ions. These carbonate ions are a fundamental component of the calcium carbonate $\left(\mathrm{CaCO}_{3}\right)$ structures of marine calcifying organisms. Already, average ocean $\mathrm{pH}$ has declined $\sim 0.1 \mathrm{pH}$ units (relative to preindustrial conditions, The Royal Society 2005) and is anticipated to drop up an additional $\sim 0.3 \mathrm{pH}$ units by the end of this century (RPC 8.5; Collins et al. 2013).

\subsection{Impacts of $\mathrm{CO}_{2}$-driven Ocean Change on Coral Reef Ecosystems}

Coral reef communities can be acutely sensitive to environmental perturbations outside of the range to which they are accustomed. For example, reef-building corals bleach when SSTs exceed their thermal-tolerance thresholds. Coral bleaching often occurs when SST rises approximately $1^{\circ} \mathrm{C}$ above average summer maximum temperature (Hoegh-Guldberg 1999) although thresholds vary widely amongst species and reefs. Bleaching is a stress response whereby corals expel their algal endosymbionts (zooxanthellae) and, in doing so, lose most of their tissue pigmentation. The coral's white calcium carbonate skeleton is then clearly visible through its tissue, giving the coral a "bleached" appearance (HoeghGuldberg \& Smith 1989, Hoegh-Guldberg 1999). Loss of zooxanthellae also means loss of a major source of coral nutrition. If corals do not recover their symbionts, they starve and eventually die. When corals die from bleaching, irreparable damage to reef systems can occur (Pandolfi et al. 2003, Donner et al. 2005). Large-scale bleaching events are expected to occur more frequently in the future as more corals and reef systems reach their thermal thresholds.

Corals also rely on heterotrophic feeding as a source of nutrition (e.g., reviewed in Ferrier-Pagès et al. 2011) and projected reductions in surface ocean nutrient concentrations and ocean productivity will affect coral food resources and as a consequence, coral growth and resilience to stress. Additionally, reduced carbonate ion availability due to OA impedes calcification by reef-building species (Kleypas et al. 1999). Numerous studies demonstrate that coral calcification declines under elevated $\mathrm{CO}_{2}$ conditions (reviewed in Doney et al. 2009, Kroeker et al. 2010, Pandolfi et al. 2011) with one even predicting that coral reefs globally will transition from net accreting to net-eroding structures when atmospheric $\mathrm{CO}_{2}$ concentrations double relative to pre-industrial levels (Silverman et al. 2009). 
Ocean warming, acidification and loss of nutrients and productivity that occur on a global scale are considered global stressors. Today, and over the course of the $21^{\text {st }}$ century, these global stressors will interact with acute, more localized pressures (e.g. overfishing, destructive fishing practices, coastal development and pollution), and together pose serious threats to the future existence of coral reefs ecosystems. Critically however, some reef systems may be naturally more resistant or resilient than others to these stressors (e.g., Glynn 1996, Riegl \& Piller 2003). Recently, it has been proposed that coral reef islands and atolls in the equatorial Pacific Ocean may act as climate change refugia for coral communities. This is due to a projected strengthening of the Pacific Equatorial Undercurrent (EUC), caused by relaxation of the trade winds in response to global warming. Such a strengthening would increase the amount of cool water that is topographically upwelled onto equatorial islands, creating a localized cooling that would reduce the large-scale, radiatively-driven warming for a subset of Pacific reef systems (Karnauskas \& Cohen 2012).

However, this specific refugia hypothesis does not yet account for the biogeochemical effects of upwelled EUC water, which is rich in dissolved inorganic nutrients (DIN) and $\mathrm{CO}_{2}$ (e.g., Knauss 1960). Although increased nutrient delivery may counter declining productivity in the vicinity of the islands, high DIN concentrations are generally considered detrimental to coral (e.g., Fabricius 2005). Further, elevated $\mathrm{CO}_{2}$ conditions generally reduce coral calcification rates and, may therefore, impact larval recruitment and shift the calcium carbonate budget of the reef system.

\subsection{Thesis Objectives}

My thesis adopts a two-pronged approach to investigate the potential for, and impacts of EUC strengthening on coral reef health through:

1. Analysis of an ocean circulation dataset for historical changes in EUC intensity. Given the ongoing increase in atmospheric $\mathrm{CO}_{2}$ and global temperatures, it is hypothesized here that EUC intensification is already occurring. GCMs generally do a poor job of capturing EUC strength (Karnauskas et al. 2012) and additional evidence for EUC intensification would further support the viability of hypothesized refugia. These analyses assess the presence and robustness of EUC strengthening in the past with an 
emphasis on physical mechanisms.

2. Experimental investigation of the coral calcification response to the combination of nutritional enhancement (via light and feeding) and elevated $\mathrm{CO}_{2}$ conditions. $\mathrm{CO}_{2}$-rich water normally reduces coral calcification, but it is possible that nutritional enhancement could mitigate, compound or have no effect on this response.

Chapter 2 assesses changes in equatorial Pacific circulation since the mid-19th century using the Simple Ocean Data Assimilation (SODA) reanalysis. This reanalysis product is an ocean circulation model that is constrained by atmospheric and ocean observations. In this data set, the EUC has strengthened significantly since the mid-1800s. Fig. 1-1 shows a relative comparison of historical and future (Karnauskas \& Cohen 2012) percent change in EUC velocity. Although Fig. 1-1a describes change in maximum EUC velocity regardless of location, while Fig. 1-1b shows the future change at a single mid-Pacific location, both indicate similar and significant increases in EUC strength. Calculation of the momentum budget of the EUC indicates that the strengthening in SODA appears to be due to two distinct seasonal mechanisms

Chapters 3 and 4 describe laboratory manipulation experiments designed to investigate the impact of heterotrophic feeding and light, on the coral calcification response to ocean acidification. Light enhances nutritional status indirectly, by stimulating symbiont photosynthesis and increasing the production of photosynthate that is transferred to the coral. These experiments quantify the coral calcification response to the nutritionally replete but relatively acidic (elevated $\mathrm{CO}_{2}$ ) conditions projected for the equatorial Pacific islands as the EUC strengthens over this century.

Several factors led us to use recently settled juveniles of the Bermudan Atlantic golf ball coral, Favia fragum as our test organism in these experiments. F. fragum are hermatypic, zooxanthellate, brooding scleractinians. Gamete fertilization and larval development occur within the mother coral polyp prior to their lunar-synchronized release as metamorphically competent larvae (Goodbody-Gringley \& de Putron 2009). The timing of larval release on Bermuda is fairly well constrained, which assists in the planning of the experiments. Newly settled juvenile corals accrete their entire $\mathrm{CaCO}_{3}$ skeleton under known experimental conditions, which facilitates interpretation of cross-treatment differences in skeletal and 
organic parameters (Cohen et al. 2009). These larvae also exhibit high percent recruitment success and survival under laboratory conditions thus ensuring sufficient sample size for experimentation. Like many scleractinians (i.e., reef-building corals), F. fragum contribute to the $\mathrm{CaCO}_{3}$ structure of the reef system and are zooxanthellate (i.e., harbor algal symbionts within their tissue). Although $F$. fragum are primarily found in the Atlantic, members of the Favia taxonomic family are also found throughout the Pacific (Veron 2000). We note that Bermudan Favia may be adapted to a relatively broad seasonal range of environmental conditions (e.g., temperature), that F. fragum tend to have smaller colony size relative to massive coral species, and that responses observed in juvenile corals, as studied here, might not be identical to those exhibited by adult colonies. For these reasons (i.e., variability among coral species, and the presence of confounding factors such as adaptation to environmental conditions and life history stage), caution is needed when extrapolating experimental results to broader reef systems. At the same time, controlled experimental studies with single model species provide a powerful tool for understanding coral calcification and its response to single and multiple stressors.

In Chapter 3, juvenile $F$. fragum were reared in either high or ambient $\mathrm{CO}_{2}$ conditions for three weeks; half of these corals were regularly fed Artemia brine shrimp. Using skeletal size (i.e., septa diameter), weight and corallite (septal cycle) development to assess coral response, we found that fed corals were significantly larger and more developmentally advanced than their unfed counterparts, regardless of $\mathrm{CO}_{2}$ level. Critically, fed corals reared under high $\mathrm{CO}_{2}$ conditions produced as much $\mathrm{CaCO}_{3}$ as unfed corals under ambient $\mathrm{CO}_{2}$ conditions. This suggests that corals in nutritionally replete systems will continue to calcify at higher rates than corals in oligotrophic, low productivity habitats as $\mathrm{CO}_{2}$ levels increase (Drenkard et al. 2013). Nevertheless, fed corals maintained the same degree of sensitivity to elevated $\mathrm{CO}_{2}$ conditions, exhibiting a similar decline in bulk calcium carbonate production with declines in saturation state as unfed corals. This suggests that, while feeding increases coral tissue biomass and the area over which $\mathrm{CaCO}_{3}$ is accreted (resulting in higher net $\mathrm{CaCO}_{3}$ production) it does not eliminate the effect of OA. Thus, feeding does not appear to the coral calcification mechanism (i.e., the effort per calcifying epithelial cell is not increased). 
In Chapter 4, juvenile $F$. fragum were again subjected to high and ambient $\mathrm{CO}_{2}$ conditions (this time for two weeks and without feeding) under either elevated or low light conditions. Unlike the effect due to feeding in Chapter 3, corals under elevated light conditions did not exhibit a significant increase in total $\mathrm{CaCO}_{3}$ production relative to corals under low light conditions, and in these experiments, we did not observe a significant effect of $\mathrm{CO}_{2}$ on coral skeletal weight. However, in a broader multi-year comparison including unfed treatment data from all three experiments, we observe a significant effect of $\mathrm{CO}_{2}$ under low light but not high light conditions. Unlike nutritional enhancement by heterotrophic feeding (which did not reduce coral calcification sensitivity to OA), elevated light conditions (which stimulate photosynthesis of the corals' algal endosymbionts) did reduce coral calcification sensitivity to OA. The mechanism for this reduced sensitivity is unclear. Calcification is an energetically costly process, suggesting that this mitigation could be due to the additional photosynthate (i.e., food) provided to the coral by the symbionts. However, while analysis of the coral tissue lipid content shows that corals grown under high light have significantly higher lipid contents than low-light light corals, there is no significant effect of $\mathrm{CO}_{2}$ on lipid content at a given light level. This implies that corals reared under high light are preferentially storing excess nutrition from their endosymbionts regardless of $\mathrm{CO}_{2}$ stress, and that a different mechanism must account for the lack of calcification sensitivity to OA.

These studies further our understanding of both the climate dynamics that may dictate EUC strengthening as well as the biological response of the coral organism to multiple stressors associated with increased EUC upwelling on equatorial Pacific reefs. Together, these results assist our efforts to quantitatively assess the climate change refugia potential of these ecosystems. 


\subsection{References}

Behrenfeld MJ, O/'Malley RT, Siegel DA, McClain CR, Sarmiento JL, Feldman GC, Milligan AJ, Falkowski PG, Letelier RM, Boss ES (2006) Climate-driven trends in contemporary ocean productivity. Nature 444: $752-755$

Cesar H, Burke L, Pet-Soede L (2003) The Economics of Worldwide Coral Reef Degradation. Cesar Environmental Economics Consulting, Arnhem, and WWF-Netherlands, Zeist, The Netherland

Cohen AL, McCorkle DC, de Putron S, Gaetani GA, Rose KA (2009) Morphological and compositional changes in the skeletons of new coral recruits reared in acidified seawater: Insights into the biomineralization response to ocean acidification. Geochemistry, Geophysics, Geosystems 10: Q07005

Collins M, Knutti R, Arblaster J, Dufresne JL, Fichefet T, Friedlingstein P, Gao X, Gutowski W, Johns T, Krinner G, Shongwe M, Tebaldi C, Weaver A, Wehner M (2013) Long-term Climate Change: Projections, Commitments and Irreversibility. In: Stocker T, Qin D, Plattner GK, Tignor M, Allen S, Boschung J, Nauels A, Xia Y, Bex V, Midgley P (eds.) Climate Change 2013: The Physical Science Basis. Contribution of Working Group I to the Fifth Assessment Report of the Intergovernmental Panel on Climate Change, Cambridge University Press, Cambridge, United Kingdom and New York, NY, USA.

Covey C, AchutaRao KM, Cubasch U, Jones P, Lambert SJ, Mann ME, Phillips TJ, Taylor KE (2003) An overview of results from the Coupled Model Intercomparison Project. Global and Planetary Change 37: 103-133

Doney SC, Fabry VJ, Feely RA, Kleypas JA (2009) Ocean Acidification: The Other $\mathrm{CO}_{2}$ Problem. Annual Review of Marine Science 1: 169-192, pMID: 21141034

Donner SD, Skirving WJ, , Little CM, Oppenheimer M, Hoegh-Guldberg O (2005) Global assessment of coral bleaching and required rates of adaptation under climate change. Global Change Biology 11: 2251-2265

Drenkard E, Cohen A, McCorkle D, de Putron S, Starczak V, Zicht A (2013) Calcification by juvenile corals under heterotrophy and elevated $\mathrm{CO}_{2}$. Coral Reefs 32: 727-735

Etheridge DM, Steele LP, Langenfelds RL, Francey RJ, Barnola JM, Morgan VI (1996) Natural and anthropogenic changes in atmospheric CO2 over the last 1000 years from air in Antarctic ice and firn. Journal of Geophysical Research: Atmospheres 101: 4115-4128

Fabricius KE (2005) Effects of terrestrial runoff on the ecology of corals and coral reefs: review and synthesis. Marine Pollution Bulletin 50: 125-146

Ferrier-Pagès C, Hoogenboom M, Houlbrèque F (2011) The Role of Plankton in Coral Trophodynamics. In: Dubinsky Z, Stambler N (eds.) Coral Reefs: An Ecosystem in Transition, 215-229, Springer Netherlands 
Friedli H, Lotscher H, Oeschger H, Siegenthaler U, Stauffer B (1986) Ice core record of the $13 \mathrm{C} / 12 \mathrm{C}$ ratio of atmospheric $\mathrm{CO}_{2}$ in the past two centuries. Nature 324: 237-238

Glynn PW (1996) Coral reef bleaching: facts, hypotheses and implications. Global Change Biology 2: 495-509

Goodbody-Gringley G, de Putron SJ (2009) Planulation patterns of the brooding coral Favia fragum (Esper) in Bermuda. Coral Reefs 28: 959-963

Hoegh-Guldberg O (1999) Climate change, coral bleaching and the future of the world's coral reefs. Marine and Freshwater Research 50: 839-866

Hoegh-Guldberg O, Smith G (1989) The effect of sudden changes in temperature, light and salinity on the population density and export of zooxanthellae from the reef corals Stylophora pistillata Esper and Seriatopora hystrix Dana. Journal of Experimental Marine Biology and Ecology 129: 279-303

Hughes TP, Baird AH, Bellwood DR, Card M, Connolly SR, Folke C, Grosberg R, HoeghGuldberg O, Jackson JBC, Kleypas J, Lough JM, Marshall P, Nyström M, Palumbi SR, Pandolfi JM, Rosen B, Roughgarden J (2003) Climate Change, Human Impacts, and the Resilience of Coral Reefs. Science 301: 929-933

Karnauskas KB, Cohen AL (2012) Equatorial refuge amid tropical warming. Nature Climate Change 2: 530-534

Karnauskas KB, Johnson GC, Murtugudde R (2012) An Equatorial Ocean Bottleneck in Global Climate Models. Journal of Climate 25: 343-349

Keeling CD (1973) Industrial production of carbon dioxide from fossil fuels and limestone. Tellus 25: 174-198

Keeling CD, Bacastow RB, Bainbridge AE, Ekdahl CA, Guenther PR, Waterman LS, Chin JFS (1976) Atmospheric carbon dioxide variations at Mauna Loa Observatory, Hawaii. Tellus 28: 538-551

Kleypas JA, Buddemeier RW, Archer D, Gattuso JP, Langdon C, Opdyke BN (1999) Geochemical Consequences of Increased Atmospheric Carbon Dioxide on Coral Reefs. Science 284: $118-120$

Knauss A John (1960) Measurements of the Cromwell current. Deep Sea Research 6: 256286

Kroeker KJ, Kordas RL, Crim RN, Singh GG (2010) Meta-analysis reveals negative yet variable effects of ocean acidification on marine organisms. Ecology Letters 13: 14191434

Moberg F, Folke C (1999) Ecological Goods and Services of Coral Reef Ecosystems. Ecological Economics 29: 215-233

Neftel A, Moor E, Oeschger H, Stauffer B (1985) Evidence from polar ice cores for the increase in atmospheric $\mathrm{CO}_{2}$ in the past two centuries. Nature 315: 45-47 
Pandolfi JM, Bradbury RH, Sala E, Hughes TP, Bjorndal KA, Cooke RG, McArdle D, McClenachan L, Newman MJH, Paredes G, Warner RR, Jackson JBC (2003) Global Trajectories of the Long-Term Decline of Coral Reef Ecosystems. Science 301: 955-958

Pandolfi JM, Connolly SR, Marshall DJ, Cohen AL (2011) Projecting Coral Reef Futures Under Global Warming and Ocean Acidification. Science 333: 418-422

Riegl B, Piller W (2003) Possible refugia for reefs in times of environmental stress. International Journal of Earth Sciences 92: 520-531

Silverman J, Lazar B, Cao L, Caldeira K, Erez J (2009) Coral reefs may start dissolving when atmospheric $\mathrm{CO}_{2}$ doubles. Geophysical Research Letters 36: L05 606

Tans P, Keeling R (2014) NOAA Earth System Reasearch Laboratory, Global Monitoring Division: Trends in Atmospheric Carbon Dioxide. http://www.esrl.noaa.gov/gmd/ccgg/trends/index.html

Taylor KE, Stouffer RJ, Meehl GA (2012) An Overview of CMIP5 and the Experiment Design. Bulletin of the American Meteorological Society 93: 485-498

The Royal Society (2005) Ocean acidification due to increasing atmospheric carbon dioxide. The Royal Society, London

Trenberth KE, Fasullo JT, Kiehl J (2009) Earth's Global Energy Budget. Bulletin of the American Meteorological Society 90: 311-323

Veron J (2000) Corals of the World, vol. 1-3. Australian Institute of Marine Science, Townsville, Australia

van der Werf GR, Morton DC, DeFries RS, Olivier JGJ, Kasibhatla PS, Jackson RB, Collatz GJ, Randerson JT (2009) $\mathrm{CO}_{2}$ emissions from forest loss. Nature Geoscience 2: 737-738 

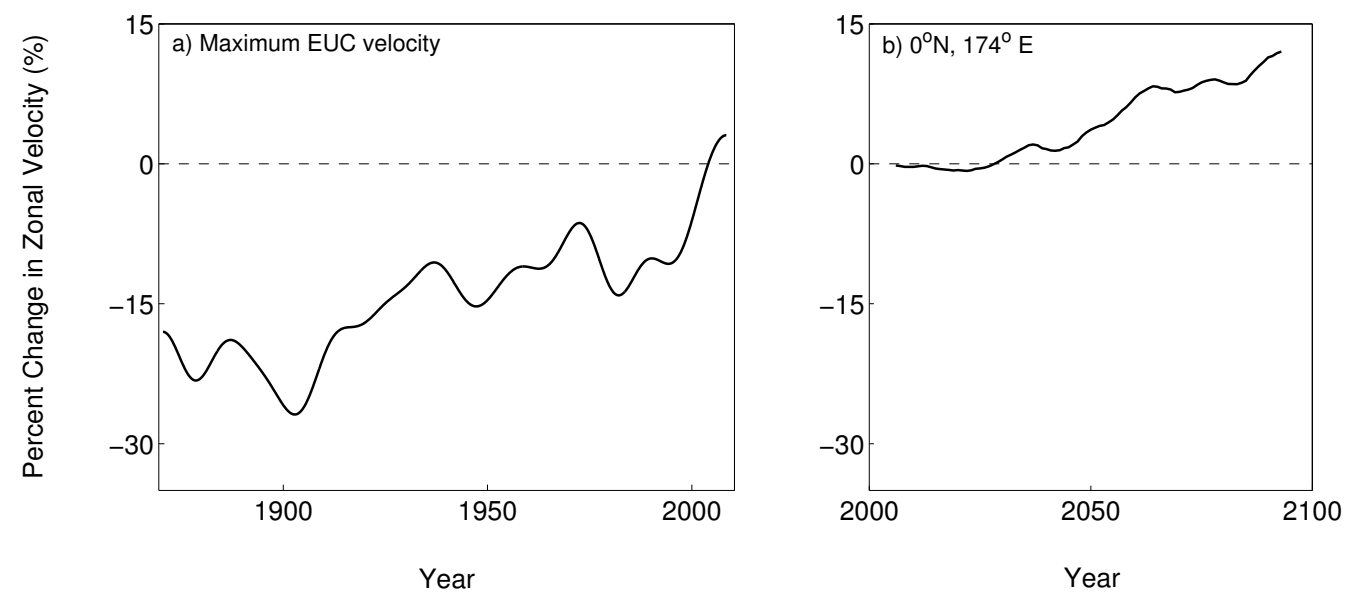

Figure 1-1: Comparison of a) historical and b) projected percent changes in EUC strength. a) is a time series of percent change in maximum zonal velocity from the SODA reanalysis that has been smoothed with a low-pass fllter (adapted from Chapter 2) while b) shows percent change in zonal velocity projected by CMIP3 models at $0^{\circ} \mathrm{N}, 174^{\circ} \mathrm{E}$ (i.e., near the Gilbert Islands; adapted from Karnauskas \& Cohen 2012) 


\section{Chapter 2}

\section{Strengthening of the Pacific Equatorial Undercurrent in the SODA Reanalysis: Mechanisms, Ocean Dynamics, and Impli- cations}

\subsection{Abstract}

Several recent studies utilizing global climate models predict that the Pacific Equatorial Undercurrent (EUC) will strengthen over the twenty-first century. Here, historical changes in the tropical Pacific are investigated using the Simple Ocean Data Assimilation (SODA) reanalysis toward understanding the dynamics and mechanisms that may dictate such a change. Although SODA does not assimilate velocity observations, the seasonalto-interannual variability of the EUC estimated by SODA corresponds well with moored observations over a $\sim 20$-yr common period. Long-term trends in SODA indicate that the EUC core velocity has increased by $16 \%$ century $^{-1}$ and as much as $47 \%$ century $^{-1}$ at fixed locations since the mid-1800s. Diagnosis of the zonal momentum budget in the equatorial Pacific reveals two distinct seasonal mechanisms that explain the EUC strengthening. The first is characterized by strengthening of the western Pacific trade winds and hence oceanic zonal pressure gradient during boreal spring. The second entails weakening of eastern Pacific trade winds during boreal summer, which weakens the surface current and reduces EUC deceleration through vertical friction. EUC strengthening has important ecological implications as upwelling affects the thermal and biogeochemical environment. Furthermore, given the potential large-scale influence of EUC strength and depth on the heat budget in the eastern Pacific, the seasonal strengthening of the EUC may help reconcile paradoxical observations of Walker circulation slowdown and zonal SST gradient strengthening. Such a process would represent a new dynamical "thermostat" on $\mathrm{CO}_{2}$-forced warming of the tropical Pacific Ocean, emphasizing the importance of ocean dynamics and seasonality in understanding climate change projections.

Drenkard EJ, Karnauskas KB (2014) Strengthening of the Pacific equatorial undercurrent in the SODA reanalysis: Mechanisms, ocean dynamics, and implications. Journal of Climate 27: 2405-2416 (C) 2014 American Meteorological Society 


\subsection{Introduction}

The Equatorial Undercurrent (EUC) is the swiftest, most coherent eastward-moving flow in the tropical Pacific Ocean (e.g., Philander 1973; Wyrtki \& Kilonsky 1984; Philander et al. 1987). The EUC slopes upward from $200 \pm 100 \mathrm{~m}$ at $156^{\circ} \mathrm{E}$ to $100 \pm 100 \mathrm{~m}$ at $95^{\circ} \mathrm{W}$ and is confined to within $\sim 2^{\circ}$ latitude of the equator (summarized in Arthur 1960; Johnson et al. 2002). The zonal pressure gradient force, related to the zonal sea level slope, is maintained by the easterly trade winds and the westward surface current and constitutes a dominant acceleration term in the momentum budget of the EUC (Knauss 1960, Knauss 1966). The balance between the eastward zonal pressure gradient force and westward surface stress determines the strength as well as zonal and vertical structure of the EUC (philander1973; McPhaden \& Taft 1988).

The EUC plays a crucial role in Pacific and global climate processes and biogeochemical cycles; it delivers cold, $\mathrm{CO}_{2}$ - and nutrient-rich water to the eastern Pacific, where it feeds the cold tongue. Here, EUC water contributes to the largest oceanic source of atmospheric $\mathrm{CO}_{2}$ (e.g., Feely et al. 2006) and to maintaining the zonal sea surface temperature (SST) gradient across the Pacific (Bjerknes 1966). This thermal gradient is one of the primary controls on tropical Pacific atmospheric circulation, which affects weather patterns and climate worldwide (e.g., Bjerknes 1969; Julian \& Chervin 1978). Additionally, upwelling of EUC water provides thermal balance and nutrients to valuable fisheries (e.g., Ganachaud et al. 2013) and equatorial island ecosystems (e.g., Houvenaghel 1978; Gove et al. 2006; Karnauskas \& Cohen 2012). Therefore, changes in EUC intensity will likely have important climatic and ecological repercussions.

Studies predicting future EUC strengthening (e.g., Luo et al. 2009; Karnauskas \& Cohen 2012; Sen Gupta et al. 2012) have attributed this change to rising concentrations of atmospheric $\mathrm{CO}_{2}$. Anthropogenic $\mathrm{CO}_{2}$ emissions have unequivocally affected atmospheric composition over the past century (Mann et al. 1999; Keeling et al. 1976). Thus it begs the question: Has the EUC already responded to historical $\mathrm{CO}_{2}$ forcing? If so, is it consistent with the future change predicted by global coupled models, is it significant, and can it be explained in a robust dynamical framework? In this study, we used the most recent version of a widely accepted ocean data assimilation product to analyze past trends in EUC 
strength and to diagnose the oceanic and atmospheric mechanisms driving these changes. The following sections describe the reanalysis dataset we analyzed and methods we followed to determine the historical trends and evaluate the equatorial Pacific zonal momentum budget. The results of these analyses are reported in section 4 and discussed within the context of their potential climatological and ecological significance in section 5 .

\section{$2.3 \quad$ Data}

We analyzed the most recent version of the Simple Ocean Data Assimilation (SODA) reanalysis (version 2.2.6; Yang \& Giese 2013) to characterize and understand historical changes in EUC strength. This version of SODA and its predecessors (Carton \& Giese 2008) are data assimilation products: ocean general circulation models constrained by quality-controlled observations. Monthly SODA fields extend from 1871 to 2008 and are the ensemble mean of eight model runs, each driven by a different realization of wind stress and variables needed for the calculation of heat and freshwater fluxes from the National Oceanic and Atmospheric Administration (NOAA) twentieth-century atmospheric reanalysis (Compo et al. 2011; Yang \& Giese 2013), thus ensuring that the statistics of weather noise do not change over time. Furthermore, version 2.2.6 assimilates observations of SST only, which prevents the appearance of spurious trends and shifts due to the rise of hydrographic measurements starting in the late 1960s. The spatial and temporal completeness of SODA allows for rigorous assessment of EUC structure and dynamics over long periods of time; such assessments are not typically possible with in situ observations alone. Throughout this paper, we frequently refer to "observed" phenomena; it should be understood that we are referring to results derived from the SODA reanalysis.

The sources of observational data assimilated vary by reanalysis product and even by version within families of reanalyses, but in no case are in situ ocean subsurface velocities assimilated. Figure 2-1 compares acoustic Doppler current profiler (ADCP) measurements of the EUC from equatorial Tropical Atmosphere Ocean (TAO; McPhaden et al. 1998) moorings with coinciding SODA estimates. We include comparison of both monthly (Figs. 2-1a,c,e,g) and normalized filtered (13-month running mean) time series (Figs. 2-1b,d,f,h) to assess correspondence between reanalysis and TAO variability at both annual and lower than annual frequencies. With the exception of $0^{\circ}, 170^{\circ} \mathrm{W}$, where there is not a significant 
difference between SODA and TAO records (Table 2.1), the SODA reanalysis tends to underestimate the EUC's maximum zonal velocity by $10 \mathrm{~cm} \mathrm{~s}^{-1}$; this may be related to the reanalysis's relatively coarse spatial resolution (Karnauskas et al. 2012). However, as evidenced by the correlation coefficients for each comparison (reported in Table 2.1) and similar comparisons in the literature (Seidel \& Giese 1999), SODA captures the seasonalto-interannual variability of the EUC quite well.

\subsection{Results}

\subsubsection{Observed trends in the EUC and other basin-scale fields}

The linear trends in the short, coinciding SODA and TAO time series are also reported in Table 2.1. With the exception of the filtered time series at $165^{\circ} \mathrm{E}$ (where proximity to land/basin edge may complicate modeled ocean dynamics), none of the SODA trends at a given longitude and smoothing regime differ significantly from their TAO counterparts. Additionally, the majority of these trends are positive and, particularly among the filtered time series, significantly greater than zero.

We first investigated the trends in annual-mean zonal velocity at a fixed point within the mean-state core of the EUC $\left(0^{\circ}, 146^{\circ} \mathrm{W}, 112 \mathrm{~m}\right.$ depth; Fig. 2-2). Here we observe a trend of $0.43 \pm 0.10 \mathrm{~m} \mathrm{~s}^{-1}$ per century (equivalent to $47 \%$ century $^{-1}$ of the annual mean) increase in zonal velocity since 1871. However, the position and structure of the EUC are not fixed in time (e.g., Philander 1973; Johnson et al. 2002) and, therefore, evaluating temporal trends in zonal velocity at a single depth and geographic location could potentially exaggerate or underrepresent comprehensive changes in the undercurrent. To account for this, we compiled and evaluated a monthly time series (Fig. 2-2) of the maximum zonal velocity found in the spatial domain: $2^{\circ} \mathrm{N}-2^{\circ} \mathrm{S}, 150^{\circ}-90^{\circ} \mathrm{W}$ and $10-300 \mathrm{~m}$ depth. This time series effectively tracks the velocity at the center of the EUC core over the course of the SODA record. The $0.17 \pm 0.03 \mathrm{~m} \mathrm{~s}^{-1}$ century $^{-1}$ trend in maximum zonal velocity indicates that the core of the EUC has sped up significantly over 1871-2008 (Fig. 2-2). This observed trend, equivalent to roughly $16 \%$ of the twentieth-century mean, is in excellent agreement with the $14.4 \%$ EUC strengthening that phase 3 of the Coupled Model Intercomparison Project (CMIP3)/ International Panel on Climate Change Fourth Assessment Report (IPCC AR4) global climate 
models predict for the twenty-first century in response to increasing atmospheric greenhouse gases (Karnauskas \& Cohen 2012).

To analyze large-scale trends in EUC velocity including their spatial variation, we repeated the analysis for Fig. $2-2$ at $0^{\circ}, 146^{\circ} \mathrm{W}$, and $112 \mathrm{~m}$ depth for all depths and longitudes along the equator. With this, we produced a depth-longitude cross section showing the long-term trends in zonal velocity (colored contours in Fig. 2-3a) set in the context of the mean-state zonal velocity (black contours in Fig. 2-3a). Because the EUC flows along the pycnocline and is sensitive to stratification (Philander 1973), we also include a complementary depth profile (Fig. 2-3b) of the vertical density gradient in order to provide additional context for the structural changes we observe in the EUC.

The longitude versus depth section of the observed trends in zonal velocity (Fig. 2-3a) illustrates the structure and nature of the observed strengthening which entails a westward translation and shoaling of the time-mean EUC core and weakening of the South Equatorial Current (SEC). The observation that the region below the EUC core also exhibits a significant trend toward a stronger, eastward velocity confirms that this is not simply a longterm translation but a significant intensification of the EUC. In the density gradient profile, the stratification increase and reduction that occurs above and below the thermocline, respectively, indicates a shoaling of the mean-state thermocline, west of $130^{\circ} \mathrm{W}$ (Fig. 2-3b). However, the regions of maximum gradient intensification and weakening do not occur at the same longitude. East of $150^{\circ} \mathrm{W}$, the shallower increase in stratification exceeds the magnitude of the deeper decrease in stratification, which suggests a sharpening of the thermocline similar to the findings of DiNezio et al. (2009). The opposite is found between $170^{\circ} \mathrm{E}$ and $150^{\circ} \mathrm{W}$, indicating a diffusing of the thermocline that spatially corresponds with the region of maximum EUC strengthening (Fig. 2-3a).

We turn now toward potential dynamical mechanisms for the observed EUC intensification. Here, we consider the long-term trends in maximum EUC velocity in relation to potential drivers for these trends. We compared, by longitude, the trends in zonal wind stress, surface zonal velocity, and maximum zonal velocity (depth range: $10-300 \mathrm{~m}$ ) on the equator (Figs. 2-4a-c, respectively). Maximum zonal velocity trends (Fig. 2-4c) indicate a significant, nearly basinwide strengthening of the EUC in excess of $0.25 \mathrm{~m} \mathrm{~s}^{-1}$ century $^{-1}$ at $150^{\circ} \mathrm{W}$. The majority of EUC strengthening (i.e., above $0.1 \mathrm{~m} \mathrm{~s}^{-1}$ century ${ }^{-1}$ ) is accompanied 
by significant slowing of the westward surface current between longitudes $180^{\circ}$ and $115^{\circ} \mathrm{W}$ (Fig. 2-4b). This speaks to the mechanism speculated upon by Karnauskas \& Cohen (2012) wherein a reduction in the friction or downward mixing of westward momentum imposed by the surface current would cause the EUC to locally accelerate. However, the long-term trend in zonal wind stress as a function of longitude (Fig. 2-4a) is at apparent odds with this mechanism: maximum EUC strengthening at $150^{\circ} \mathrm{W}$ does not coincide with the point of maximum wind stress weakening $\left(\sim 105^{\circ} \mathrm{W}\right)$. Two observations in particular prompted the remainder of our efforts to diagnose EUC intensification: The nonuniformity in zonal wind stress trends across the basin (i.e., weakening in the east versus strengthening in the west) likely affects the longitudinal gradient in sea surface height, which suggests that forces such as the zonal pressure gradient may also influence the observed trends in EUC strength. Additionally, the trends shown in Fig. 2-4 are annual mean perspectives; if the dynamics driving EUC acceleration are seasonally dependent, averaging over the annual cycle may obscure specific mechanisms.

Therefore, we also considered seasonal trends in zonal wind stress, surface ocean velocity, sea surface height, zonal transport, and maximum zonal velocity (colored contours in Figs. 2-5a-e, respectively). Each field is shown in the context of its climatology (black contours in Figs. 2-5a-e). We used a depth range of 0-640m (first 20 depth layers in SODA reanalysis) to calculate zonal transport, a depth range of $10-300 \mathrm{~m}$ to determine maximum zonal velocity, and a horizontal dimension of $110.6 \mathrm{~km}$ between latitudes for calculating transport between $0.5^{\circ} \mathrm{N}$ and $0.5^{\circ} \mathrm{S}$. Climatological Hövmoller diagrams (longitude versus time; Fig. 2-5) highlight two seasons within the annual cycle that clearly dominate the observed EUC intensification. These periods are March - May (MAM) and June - August (JJA); they are characterized by the largest positive trends in eastward volume transport (Fig. 2-5d) and maximum zonal velocity (Fig. 2-5e). The MAM intensification occurs approximately one month after maximum strengthening of the easterly trades and westward surface velocity in the western Pacific (Figs. 2-5a,b) and is concurrent with an increase in the zonal gradient of sea surface height (SSH; Fig. 2-5c). This suggests that the long-term acceleration of the EUC during MAM is related to the zonal pressure gradient rather than a reduction of vertical friction. In contrast, EUC core strengthening during JJA occurs when the weakening trend in both the eastern Pacific zonal wind stress (Fig. 2-5a) and, to a greater extent, the 
westward surface current (Fig. 2-5b) is prominent. Therefore, it appears that the dynamical mechanisms driving the observed EUC intensification are caused by a seasonally dependent combination of both local (i.e., friction) and nonlocal (i.e., basin-scale pressure gradient) factors. Investigation into long-term changes in ocean kinematics from the view of the zonal momentum budget during both MAM and JJA is the subject of the following section.

\subsubsection{Diagnosis of the zonal momentum equation}

To formally elucidate the mechanism and drivers of historical changes in the EUC we performed a thorough analysis of the zonal momentum budget, which is similar to the approach of Brown et al. (2007) and Qiao \& Weisberg (1997). We use the following rearrangement of the zonal momentum equation (ZME):

$$
\frac{\partial u}{\partial t}=-u \frac{\partial u}{\partial x}-v \frac{\partial u}{\partial z}-w \frac{\partial u}{\partial z}-\frac{1}{\rho} \frac{\partial P}{\partial x}+2 \Omega v \sin \vartheta+A_{H} \nabla^{2} u+\frac{\partial}{\partial z}\left[A_{v}\left(\frac{\partial u}{\partial z}\right)\right]
$$

where $\partial u / \partial t$ is the time rate of change in zonal velocity; $u \partial u / \partial x, v \partial u / \partial y$, and $w \partial u / \partial z$ represent the nonlinear advective terms; $-(1 / \rho)(\partial P / \partial x)$ is the zonal pressure gradient force; and $2 \Omega v \sin \vartheta$ is the Coriolis force where $\Omega$ is the rotation of Earth and $\vartheta$ is the latitude at which the ZME $(2.1)$ is evaluated. Finally, $A_{H} \nabla^{2} u$, or $(\partial / \partial x)\left[A_{H}(\partial u / \partial x)\right]+$ $(\partial / \partial y)\left[A_{H}(\partial u / \partial y)\right]$, are the horizontal friction terms while $(\partial / \partial z)\left[A_{V}(\partial u / \partial z)\right]$ is the vertical friction term. All SODA fields were interpolated from their original depth divisions to regular, 5m intervals; partial derivatives were calculated via central finite differencing. Density was calculated based on the equation of state using salinity, temperature and depth (Fofonoff \& Millard 1983); $A_{H}$ and $A_{V}$ are the horizontal and vertical coefficients of eddy viscosity, respectively. Because these coefficients were not retained following each model run of the SODA reanalysis (B. Giese 2013, personal communication), we estimated or calculated them in the following way: We assigned $A_{H}$ a constant value of $1.5 \times 10^{-3} \mathrm{~m}^{2} \mathrm{~s}^{-1}$ (Wallcraft et al. 2005), while we varied the value of $A_{V}$ with depth: $4.5 \times 10^{-3} \mathrm{~m}^{2} \mathrm{~s}^{-1}$ above the thermocline, $0.3 \times 10^{-3} \mathrm{~m}^{2} \mathrm{~s}^{-1}$ within the thermocline, $1.5 \times 10^{-3} \mathrm{~m}^{2} \mathrm{~s}^{-1}$ below the thermocline, and a smooth spline interpolation in between (Qiao \& Weisberg 1997). These values are not well known and are, consequently, a primary source of uncertainty in our 
calculations that leads to a nontrivial mean residual. However, we only invoke the temporal change in these terms to explain seasonal EUC intensification mechanisms (i.e., Fig. 2-7, described in greater detail below), which is not influenced by methodological uncertainties to the same extent. Friction terms were calculated on isopycnal layers and thus all terms are displayed in an isopycnic coordinate system.

For reference, shown in Fig. 2-6 are the SODA record mean longitudinal profiles of zonal wind stress $\tau_{x}$ and SSH (Fig.2-6a), vertical sections of zonal velocity $u$ (Fig. 2-6b), and individual terms of the zonal momentum equation (Figs. 2-6c-h). Note that, because of the central differencing approach used for calculating the vertical friction term, we are unable to resolve the upper and lower two isopycnal layers. The zonal pressure gradient force, nonlinear vertical advection, and vertical friction terms are the most dominant terms balancing the time-mean state and play the largest role in distinguishing the two seasonal mechanisms of EUC strengthening.

We then evaluated the change in each of the ZME components in the equatorial Pacific by differencing terms that were calculated using the seasonal, time-mean fields for the fourth versus first quarters (i.e., each $35 \mathrm{yr}$ ) of the SODA reanalysis (Fig. 2-7). Other methods were checked to confirm the insensitivity of the salient results to such temporal choices. During MAM, the EUC strengthens at its core and in the western Pacific while a stronger surface current weakens the undercurrent and depresses the EUC core depth in the eastern Pacific (Fig. 2-7c). Stronger easterly trade winds coincide with stronger zonal SSH and pressure gradients (cf. Figs. 2-7a,g). The vertical nonlinear advective term $(w \partial u / \partial z$; Fig. 2-7e) exhibits a strong eastward acceleration within the upper layers of the EUC, while the vertical friction term $\left\{(\partial / \partial z)\left[A_{V}(\partial u / \partial z)\right]\right.$; Fig. 2-7i $\}$ shows a westward surface acceleration, which is in opposition to the flow of the EUC.

Conversely, EUC intensification during JJA is concentrated at and near the surface of the eastern equatorial Pacific (Fig. 2-7d); this is zonally aligned with a pronounced weakening of the easterly trade winds (Fig. 2-7b) and the zonal pressure gradient force (Fig. 2-7h). Additionally, both the vertical nonlinear advective and friction terms (Figs. 2-7f \& j, respectively) exhibit eastward acceleration within this region of maximum EUC strengthening (i.e., east of $160^{\circ} \mathrm{W}$ ). EUC intensification in the west is associated with a less pronounced strengthening of the trade winds (Fig. 2-7b) and the zonal pressure gradient 
force (Fig. 2-7h) between $170^{\circ} \mathrm{E}$ and $160^{\circ} \mathrm{W}$.

\subsection{Summary and Discussion}

We have shown that the EUC has strengthened significantly in the SODA reanalysis since the mid nineteenth century, a signal that is even apparent in the short-term TAO in situ record (Table 2.1 and Fig. 2-1). Analyses of long-term trends in zonal velocity indicate that this intensification entails a shoaling, vertical broadening, and westward migration of the EUC core. These structural changes in the undercurrent are tightly coupled with stratification trends and, despite different mechanisms, are similar to those projected by Luo et al. (2009; cf. Fig. 3) and Sen Gupta et al. (2012; cf. Fig. 1b).

Further investigation into equatorial Pacific climatological trends and zonal momentum budget indicates that the majority of observed, historical EUC strengthening is explained by two seasonally and dynamically different mechanisms. The intensification observed during boreal spring locally appears to be caused by a strengthening of the easterly trade winds in the west. This increases the zonal SSH gradient and, consequently, the zonal pressure gradient, which accelerates the core of the EUC in the western Pacific. The shallow, eastward acceleration in the vertical nonlinear advective term is tightly linked to this process. This advective term is influenced by intensified equatorial upwelling (i.e., larger $w$ ) because of the faster westward surface current and by zonal momentum advected upward from the accelerated EUC core, which crosses a larger vertical gradient in zonal velocity (i.e., larger $\partial u / \partial z)$. However, the westward wind stress, as well as subsequent vertical transmission of friction, resists this intensification and slows and depresses the core depth of the EUC in the east. This mechanism strongly resembles the mean state of the equatorial Pacific and thus operates within the canonical dynamics governing the mean EUC (e.g., Fofonoff \& Montgomery 1955; Knauss 1960).

In light of historical observations of EUC weakening or even disappearance during strong

El Niño events (e.g., Firing et al. 1983), it is at first counterintuitive to also observe a strengthening of the EUC during JJA when the weakening trend in both the easterly trade winds and the westward surface current is so prominent. In the SODA reanalysis, the longterm weakening of the eastern Pacific trade winds causes a local flattening of the zonal SSH and pressure gradients. If relying strictly on ENSO correlations, one might expect the EUC 
to weaken. Instead, we observe a strong and shallow intensification of the EUC in close synchrony with the seasonal weakening of the easterly trades. This appears to be largely apparent in the eastward acceleration in the vertical friction term $(\partial / \partial z)\left[A_{V}(\partial u / \partial z)\right]$, which is influenced by both the change in the vertical gradient of zonal velocity $(\partial u / \partial z$; primarily determined here by zonal wind stress) as well as the increase in stratification (Fig. 23b). Finally, the nonlinear vertical advection term $(w \partial u / \partial z)$ also contributes to shallow strengthening of the EUC. Apparently the magnitude of the change in the vertical gradient in zonal velocity $(\partial u / \partial z)$ exceeds the reduction in upwelling (i.e., smaller $w$ ) that also is caused by slowing of the trades and surface current and increased stratification.

The underlying mechanism and EUC strengthening during boreal summer may be analogous to that projected by climate models, which exhibit a weakening Walker circulation (Vecchi \& Soden 2007; Karnauskas \& Cohen 2012). Additionally, it may be a key to reconciling historical observations of weakened Walker circulation with strengthening Pacific zonal SST gradient. Vecchi et al. (2006) report a 3.5\% slowdown of Pacific Walker circulation since 1860 (and project a 10\% decrease by 2100) based on CMIP3 simulations. As they point out, such a reduction in zonal wind stress would weaken equatorial upwelling and effectively reduce the amount of cold water brought up from depth, resulting in a warming of the eastern Pacific cold tongue. However, this is fundamentally at odds with the long line of studies reporting observations of a historical cooling trend in the eastern equatorial Pacific Ocean (Cane et al. 1997; Karnauskas et al. 2009; Compo \& Sardeshmukh 2010; Kumar et al. 2010; Zhang et al. 2010; Solomon \& Newman 2012; L'Heureux et al. 2013). The mechanism dominant in JJA exhibits both a weakening of the easterly trade winds, which would appear to be consistent with a weakening of the Walker circulation, and a means of increasing the zonal SST gradient: namely, a shoaling and robust strengthening of the thermocline and EUC. However, bulk measures of the Walker circulation such as SLP differences and basin-mean zonal winds, especially in an annual-mean-only basis, likely do not encapsulate the dynamics and time scales that the ocean actually responds to.

Both increased stratification and EUC intensification can be invoked as possible contributors to seasonal surface cooling. DiNezio et al. (2009) demonstrate that, despite reductions in upwelling, increased stratification (e.g., Fig. 2-3b) can lead to a net cooling in the eastern Pacific. Additionally, Moum et al. (2013) highlight the critical role of ocean mixing driving 
sea surface cooling during boreal summer. Changing subsurface zonal velocity and vertical shear may further stimulate turbulent mixing and enhance this seasonal cooling. Certainly the efficacy of the coupling mechanism we propose here depends upon a number of factors: not least of which is the impact of climate change on the temperature of the water masses that feed the EUC (Cane et al. 1997). Further work focusing on the mixed-layer heat budget is necessary to confirm this speculation but may yield a mechanism parallel to that described by Sun \& Liu (1996), Clement et al. (1996), and Seager \& Murtugudde (1997) as an ocean dynamical thermostat.

It should be noted that this study does not directly address off-equatorial mechanisms for EUC trends, and recent studies such as those addressing the western boundary currents that feed the EUC as prominent drivers of intensification (Luo et al. 2009; Sen Gupta et al. 2012) are possibly complementary rather than mutually exclusive. Indeed, our momentum budget analyses focus on the two seasons that exhibit the largest increase in maximum zonal velocity and transport. However, these fields, particularly maximum velocity (Fig. 2-5e), show strengthening throughout most of the annual cycle. This may be driven by an increase in the zonal sea surface height gradient (and thus, pressure gradient force), which is characterized in part by a persistent, year-long elevation in the western Pacific (Fig. 23c). This signal is highly suggestive of off-equatorial drivers such as strengthening western boundary currents, for both their dynamical influence and the absence of a clear causative signal in seasonal wind stress (Fig. 2-5a), and further illustrates the potential for multiple oceanic-atmospheric drivers contributing to changing tropical circulation.

A strengthening of the EUC has important implications for affected equatorial Pacific island and oceanic ecosystems. Topographic upwelling of the EUC delivers cold, nutrientand $\mathrm{CO}_{2}$-rich water to the surface and plays a fundamental role in dictating the structure and evolution of exposed ecosystems (Houvenaghel 1978). Such regions have been proposed as potential priorities for enhanced conservation efforts because they may locally mitigate and are thus resilient to the rapidity of ocean surface warming that poses a serious threat to tropical coral reef ecosystems (West \& Salm 2003). Karnauskas \& Cohen (2012) specifically highlight the refugia potential of equatorial Pacific islands because of the modeled cooling influence of predicted EUC intensification. However, enhanced upwelling could also adversely impact exposed coral reefs because $\mathrm{CO}_{2}$-rich EUC water may deter calcium car- 
bonate and thus essential framework production on these ecosystems (Feely et al. 2008; Manzello et al. 2008). An historical precedence for EUC intensification is valuable because investigation into past reef response to EUC strengthening may enable fishery managers and marine conservation planners to better anticipate and plan for the inevitable ecological consequences of future changes in ocean temperatures, circulation, and nutrient supply.

\subsection{Acknowledgments}

The authors gratefully acknowledge Benjamin Giese for his tireless efforts to improve the SODA reanalysis product, for his assistance in procuring the version 2.2.6 fields, and for his insightful feedback on this manuscript. The authors also thank the three anonymous reviewers for their constructive suggestions. EJD is supported by NSF Grants OCE-1031971 and OCE-1233282. KBK is supported by NSF Grant OCE-1233282. 


\section{$2.7 \quad$ References}

Arthur RS (1960) A review of the calculation of ocean currents at the equator. Deep Sea Research 6: 287-297

Bjerknes J (1966) A possible response of the atmospheric Hadley circulation to equatorial anomalies of ocean temperature. Tellus 18: 820-829

Bjerknes J (1969) Atomspheric teleconnections from the Equatorial Pacific. Monthly Weather Review 97: 163-172

Brown JN, Godfrey JS, Fiedler R (2007) A Zonal Momentum Balance on Density Layers for the Central and Eastern Equatorial Pacific. Journal of Physical Oceanography 37: $1939-1955$

Cane MA, Clement AC, Kaplan A, Kushnir Y, Pozdnyakov D, Seager R, Zebiak SE, Murtugudde R (1997) Twentieth-Century Sea Surface Temperature Trends. Science 275: 957960

Carton JA, Giese BS (2008) A Reanalysis of Ocean Climate Using Simple Ocean Data Assimilation (SODA). Monthly Weather Review 136: 2999-3017

Clement AC, Seager R, Cane MA, Zebiak SE (1996) An Ocean Dynamical Thermostat. Journal of Climate 9: 2190-2196

Compo GP, Sardeshmukh PD (2010) Removing ENSO-Related Variations from the Climate Record. Journal of Climate 23: 1957-1978

Compo GP, Whitaker JS, Sardeshmukh PD, Matsui N, Allan RJ, Yin X, Gleason BE, Vose RS, Rutledge G, Bessemoulin P, Brönnimann S, Brunet M, Crouthamel RI, Grant AN, Groisman PY, Jones PD, Kruk MC, Kruger AC, Marshall GJ, Maugeri M, Mok HY, Nordli Ø, Ross TF, Trigo RM, Wang XL, Woodruff SD, Worley SJ (2011) The Twentieth Century Reanalysis Project. Quarterly Journal of the Royal Meteorological Society 137: $1-28$

DiNezio PN, Clement AC, Vecchi GA, Soden BJ, Kirtman BP, Lee SK (2009) Climate Response of the Equatorial Pacific to Global Warming. Journal of Climate 22: 48734892

Feely RA, Takahashi T, Wanninkhof R, McPhaden MJ, Cosca CE, Sutherland SC, Carr ME (2006) Decadal variability of the air-sea CO2 fluxes in the equatorial Pacific Ocean. Journal of Geophysical Research: Oceans 111: C08S90

Feely RA, Sabine CL, Hernandez-Ayon JM, Ianson D, Hales B (2008) Evidence for Upwelling of Corrosive "Acidified" Water onto the Continental Shelf. Science 320: 14901492

Firing E, Lukas R, Sadler J, Wyrtki K (1983) Equatorial Undercurrent Disappears During 1982-1983 El Niño. Science 222: 1121-1123 
Fofonoff NP, Millard RC (1983) Algorithms for computation of fundamental properties of seawater. UNESCO Technical Papers in Marine Science 44: $53 \mathrm{pp}$

Fofonoff NP, Montgomery RB (1955) The Equatorial Undercurrent in the Light of the Vorticity Equation1. Tellus 7: 518-521

Ganachaud A, Sen Gupta A, Brown J, Evans K, Maes C, Muir L, Graham F (2013) Projected changes in the tropical Pacific Ocean of importance to tuna fisheries. Climatic Change 119: 163-179

Gove JM, Merrifield MA, Brainard RE (2006) Temporal variability of current-driven upwelling at Jarvis Island. Journal of Geophysical Research: Oceans 111: C12 011

Houvenaghel G (1978) Oceanographic conditions in the Galapagos Archipelago and their telationships with life on the islands. In: Boje R, Tomczak M (eds.) Upwelling Ecosystems, 181-200, Springer Berlin Heidelberg

Johnson GC, Sloyan BM, Kessler WS, McTaggart KE (2002) Direct measurements of upper ocean currents and water properties across the tropical Pacific during the 1990s. Progress in Oceanography 52: 31-61

Julian PR, Chervin RM (1978) A Study of the Southern Oscillation and Walker Circulation Phenomenon. Monthly Weather Review 106: 1433-1451

Karnauskas KB, Cohen AL (2012) Equatorial refuge amid tropical warming. Nature Climate Change 2: $530-534$

Karnauskas KB, Seager R, Kaplan A, Kushnir Y, Cane MA (2009) Observed Strengthening of the Zonal Sea Surface Temperature Gradient across the Equatorial Pacific Ocean. Journal of Climate 22: 4316-4321

Karnauskas KB, Johnson GC, Murtugudde R (2012) An Equatorial Ocean Bottleneck in Global Climate Models. Journal of Climate 25: 343-349

Keeling CD, Bacastow RB, Bainbridge AE, Ekdahl CA, Guenther PR, Waterman LS, Chin JFS (1976) Atmospheric carbon dioxide variations at Mauna Loa Observatory, Hawaii. Tellus 28: 538-551

Knauss A John (1960) Measurements of the Cromwell current. Deep Sea Research 6: 256286

Knauss A John (1966) Further measurements and observations on the Cromwell Current. Journal of Marine Research 24: 205-240

Kumar A, Jha B, L'Heureux M (2010) Are tropical SST trends changing the global teleconnection during La Niña? Geophysical Research Letters 37: L12 702

L'Heureux ML, Lee S, Lyon B (2013) Recent multidecadal strengthening of the Walker circulation across the tropical Pacific. Nature Climate Change 3: 571-576

Luo Y, Rothstein LM, Zhang RH (2009) Response of Pacific subtropical-tropical thermocline water pathways and transports to global warming. Geophysical Research Letters 36: L04 601 
Mann ME, Bradley RS, Hughes MK (1999) Northern hemisphere temperatures during the past millennium: Inferences, uncertainties, and limitations. Geophysical Research Letters 26: $759-762$

Manzello DP, Kleypas JA, Budd DA, Eakin CM, Glynn PW, Langdon C (2008) Poorly cemented coral reefs of the eastern tropical Pacific: Possible insights into reef development in a high-CO2 world. Proceedings of the National Academy of Sciences 105: 10 450-10 455

McPhaden MJ, Taft BA (1988) Dynamics of Seasonal and Intraseasonal Variability in the Eastern Equatorial Pacific. Journal of Physical Oceanography 18: 1713-1732

McPhaden MJ, Busalacchi AJ, Cheney R, Donguy JR, Gage KS, Halpern D, Ji M, Julian P, Meyers G, Mitchum GT, Niiler PP, Picaut J, Reynolds RW, Smith N, Takeuchi K (1998) The Tropical Ocean-Global Atmosphere observing system: A decade of progress. Journal of Geophysical Research: Oceans 103: 14169-14240

Moum JN, Perlin A, Nash JD, McPhaden MJ (2013) Seasonal sea surface cooling in the equatorial Pacific cold tongue controlled by ocean mixing. Nature 500: 64-67

Philander SGH (1973) equatorial undercurrent: Measurements and theories. Reviews of Geophysics 11: 513-570

Philander SGH, Hurlin WJ, Seigel AD (1987) Simulation of the Seasonal Cycle of the Tropical Pacific Ocean. Journal of Physical Oceanography 17: 1986-2002

Qiao L, Weisberg RH (1997) The Zonal Momentum Balance of the Equatorial Undercurrent in the Central Pacific. Journal of Physical Oceanography 27: 1094-1119

Seager R, Murtugudde R (1997) Ocean Dynamics, Thermocline Adjustment, and Regulation of Tropical SST. Journal of Climate 10: 521-534

Seidel HF, Giese BS (1999) Equatorial currents in the Pacific Ocean 1992-1997. Journal of Geophysical Research: Oceans 104: 7849-7863

Sen Gupta A, Ganachaud A, McGregor S, Brown JN, Muir L (2012) Drivers of the projected changes to the Pacific Ocean equatorial circulation. Geophysical Research Letters 39: L09 605

Solomon A, Newman M (2012) Reconciling disparate twentieth-century Indo-Pacific ocean temperature trends in the instrumental record. Nature Clim Change 2: 691-699

Sun DZ, Liu Z (1996) Dynamic Ocean-Atmosphere Coupling: A Thermostat for the Tropics. Science 272: 1148-1150

Vecchi GA, Soden BJ (2007) Global Warming and the Weakening of the Tropical Circulation. Journal of Climate 20: 4316-4340

Vecchi GA, Soden BJ, Wittenberg AT, Held IM, Leetmaa A, Harrison MJ (2006) Weakening of tropical Pacific atmospheric circulation due to anthropogenic forcing. Nature 441: 7376 
Wallcraft AJ, Kara AB, Hurlburt HE (2005) Convergence of Laplacian diffusion versus resolution of an ocean model. Geophysical Research Letters 32: L07 604

West JM, Salm RV (2003) Resistance and Resilience to Coral Bleaching: Implications for Coral Reef Conservation and Management. Conservation Biology 17: 956-967

Wyrtki K, Kilonsky B (1984) Mean Water and Current Structure during the Hawaii-toTahiti Shuttle Experiment. Journal of Physical Oceanography 14: 242-254

Yang C, Giese BS (2013) El Niño Southern Oscillation in an ensemble ocean reanalysis and coupled climate models. Journal of Geophysical Research: Oceans 118: 4052-4071

Zhang W, Li J, Zhao X (2010) Sea surface temperature cooling mode in the Pacific cold tongue. Journal of Geophysical Research: Oceans 115: C12 042 


\begin{tabular}{|c|c|c|c|c|c|}
\hline & & \multicolumn{4}{|c|}{ Equatorial TAO locations (lon) } \\
\hline & & $165^{\circ} \mathrm{E}$ & $170^{\circ} \mathrm{W}$ & $140^{\circ} \mathrm{W}$ & $110^{\circ} \mathrm{W}$ \\
\hline \multirow[t]{4}{*}{ Monthly time Series } & $R$ & 0.53 & 0.75 & 0.82 & 0.75 \\
\hline & $\operatorname{Bias}\left(\mathrm{ms}^{-1}\right)$ & -0.08 & 0.01 & -0.14 & -0.10 \\
\hline & $\begin{array}{l}\text { ADCP trend } \\
\left(\mathrm{ms}^{-1} \text { century }{ }^{-1}\right)\end{array}$ & $0.61 \pm 0.63$ & $0.44 \pm 0.71$ & $1.15 \pm 0.94^{*}$ & $0.61 \pm 1.18$ \\
\hline & $\begin{array}{l}\text { SODA trend } \\
\left(\mathrm{ms}^{-1} \text { century }^{-1}\right)\end{array}$ & $-0.16 \pm 0.58$ & $0.71 \pm 0.62^{*}$ & $2.10 \pm 0.83^{*}$ & $0.82 \pm 1.01$ \\
\hline \multirow{4}{*}{$\begin{array}{l}\text { Monthly time Series } \\
\text { (13-month smoothing filter) }\end{array}$} & $R$ & 0.60 & 0.84 & 0.91 & 0.93 \\
\hline & $\operatorname{Bias}\left(\mathrm{ms}^{-1}\right)$ & -0.09 & 0.01 & -0.14 & -0.10 \\
\hline & $\begin{array}{l}\text { ADCP trend } \\
\left(\mathrm{ms}^{-1} \text { century }^{-1}\right)\end{array}$ & $0.70 \pm 0.44^{*}$ & $0.64 \pm 0.47^{*}$ & $1.31 \pm 0.43^{*}$ & $0.70 \pm 0.39^{*}$ \\
\hline & $\begin{array}{l}\text { SODA trend } \\
\left(\mathrm{ms}^{-1} \text { century }^{-1}\right)\end{array}$ & $-0.17 \pm 0.31$ & $0.73 \pm 0.40^{*}$ & $2.20 \pm 0.44^{*}$ & $0.91 \pm 0.51^{*}$ \\
\hline
\end{tabular}

*Statistically significant trend $(\alpha=0.01)$.

Table 2.1: Correlation coefficients R, average SODA-ADCP bias, and linear trends for both monthly and filtered time series. All correlation and bias values (with the exception of biases reported at $\left.170^{\circ} \mathrm{W}\right)$ are significant $(\alpha=0.01 ; \mathrm{p}<0.001)$. 


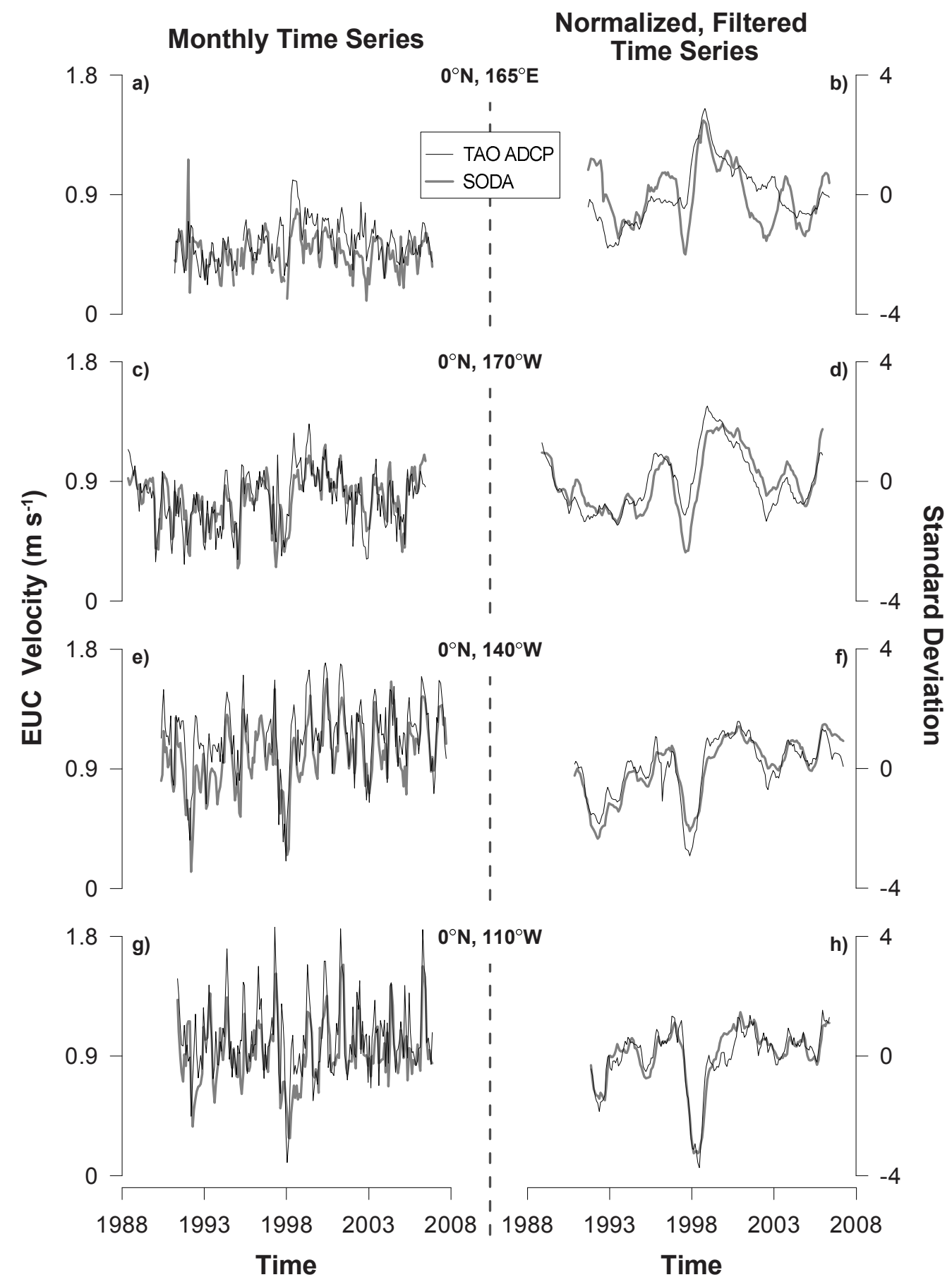

Figure 2-1: Comparison of maximum EUC zonal velocity estimated by SODA (grey) and Acoustic Doppler Current Profiler (ADCP) measurements by equatorial TAO moorings (black) at $0^{\circ} \mathrm{N}$ and $(\mathrm{a}, \mathrm{b}) 165^{\circ} \mathrm{E}(\mathrm{c}, \mathrm{d}) 170^{\circ} \mathrm{W}(\mathrm{e}, \mathrm{f}) 140^{\circ} \mathrm{W}$ and $(\mathrm{g}, \mathrm{h}) 110^{\circ} \mathrm{W}$. The ADCP data were regridded via linear interpolation to depth intervals that match the vertical resolution of SODA; maximum velocities located below 300 meters were masked out. The plots on the left (a, c, e, g) compare the monthly time series of maximum zonal velocity while the plots on the right $(b, d, f, h)$ compare these time series after filtering (13-month running mean) and normalization. 


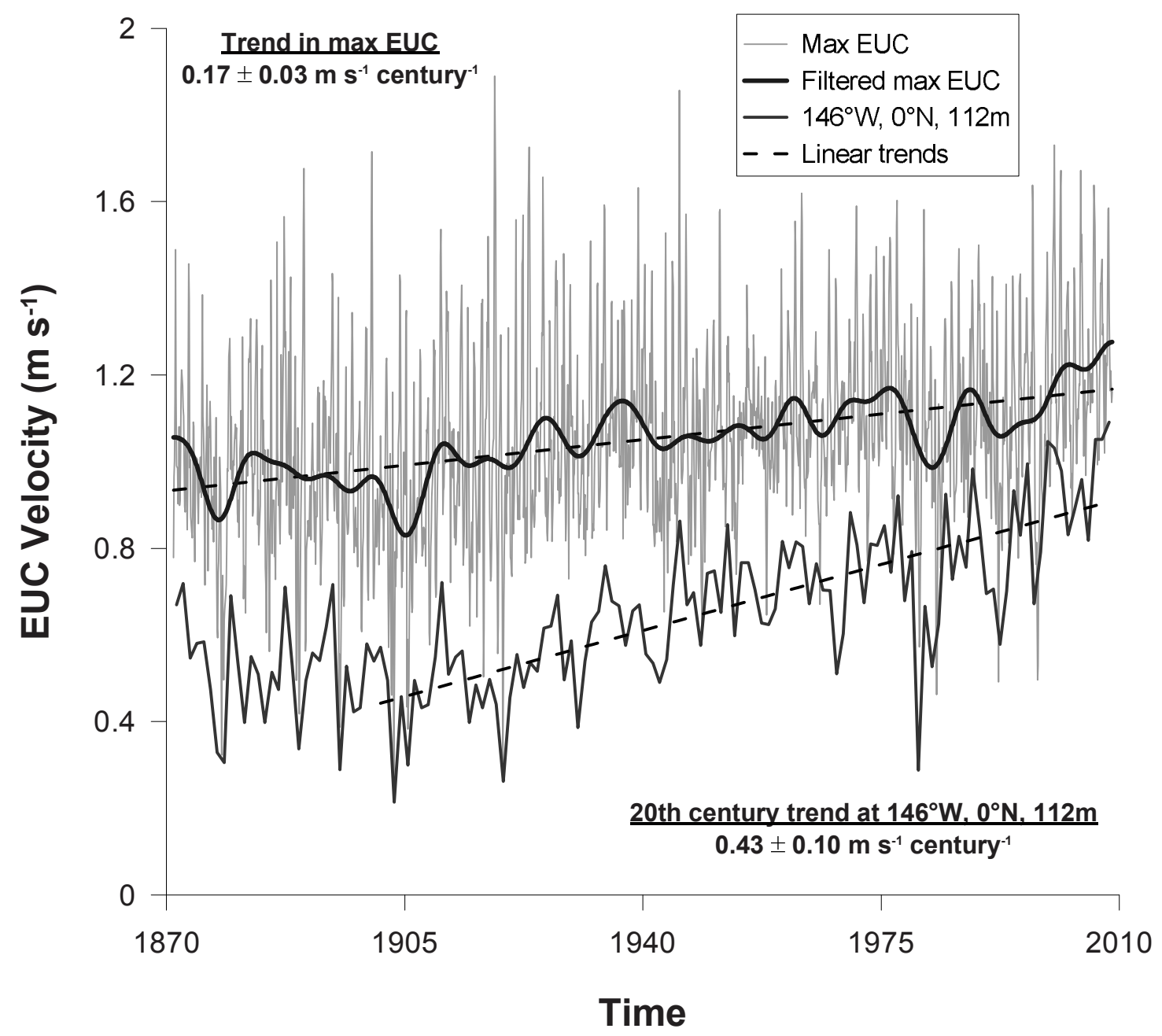

Figure 2-2: Time series of maximum EUC strength and zonal velocity at $146^{\circ} \mathrm{W}, 0^{\circ} \mathrm{N}$, $112 \mathrm{~m}$. The solid, pale grey line depicts the monthly maximum velocity from SODA within the domain of the EUC core (i.e. latitude: $2^{\circ} \mathrm{N}-2^{\circ} \mathrm{S}$; longitude: $150^{\circ} \mathrm{W}-90^{\circ} \mathrm{W}$; depth: $10-300$ meters), while the thick black line is a 7-year filtering of this time series. The solid, dark grey line indicates the annual mean zonal velocity at the fixed location: $146^{\circ} \mathrm{W}, 0^{\circ} \mathrm{N}, 112 \mathrm{~m}$. Lastly, we report two linear trends (i.e. regression slopes; dashed lines) for the annual and monthly time series, both of which are significant at the $99 \%$ confidence interval. 
a) Zonal velocity $\left(\mathrm{m} \mathrm{s}^{-1}\right)$

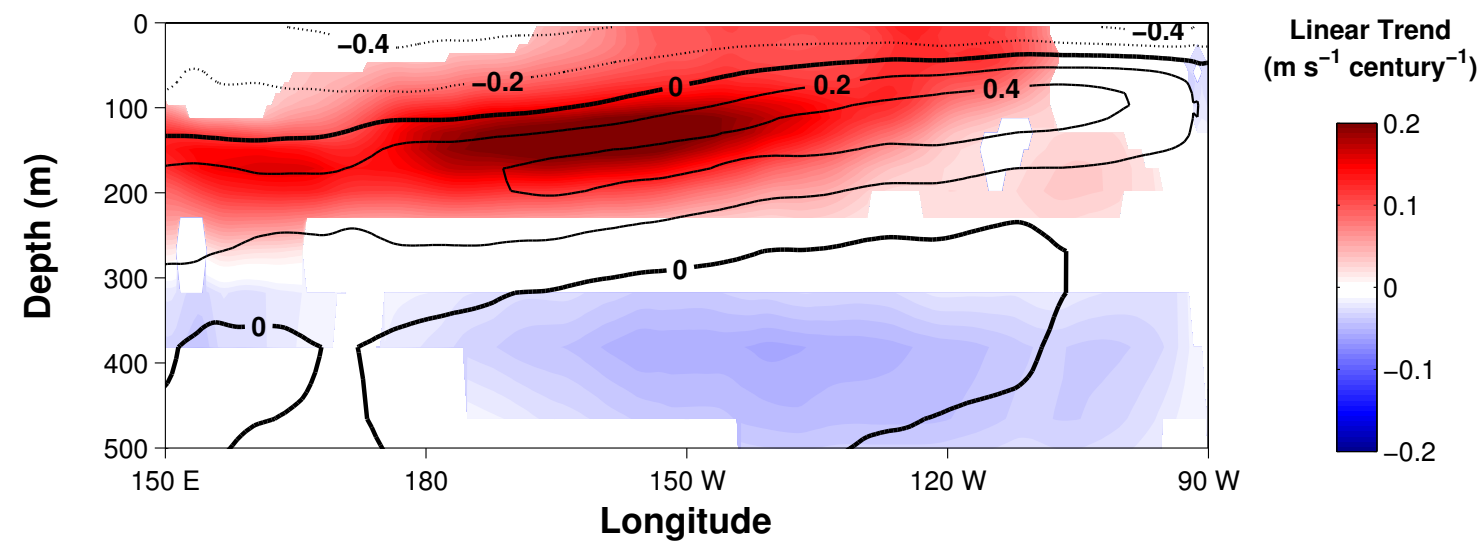

b) Vertical density gradient $\left(\times 10^{-3} \mathrm{~kg} \mathrm{~m}^{-4}\right)$

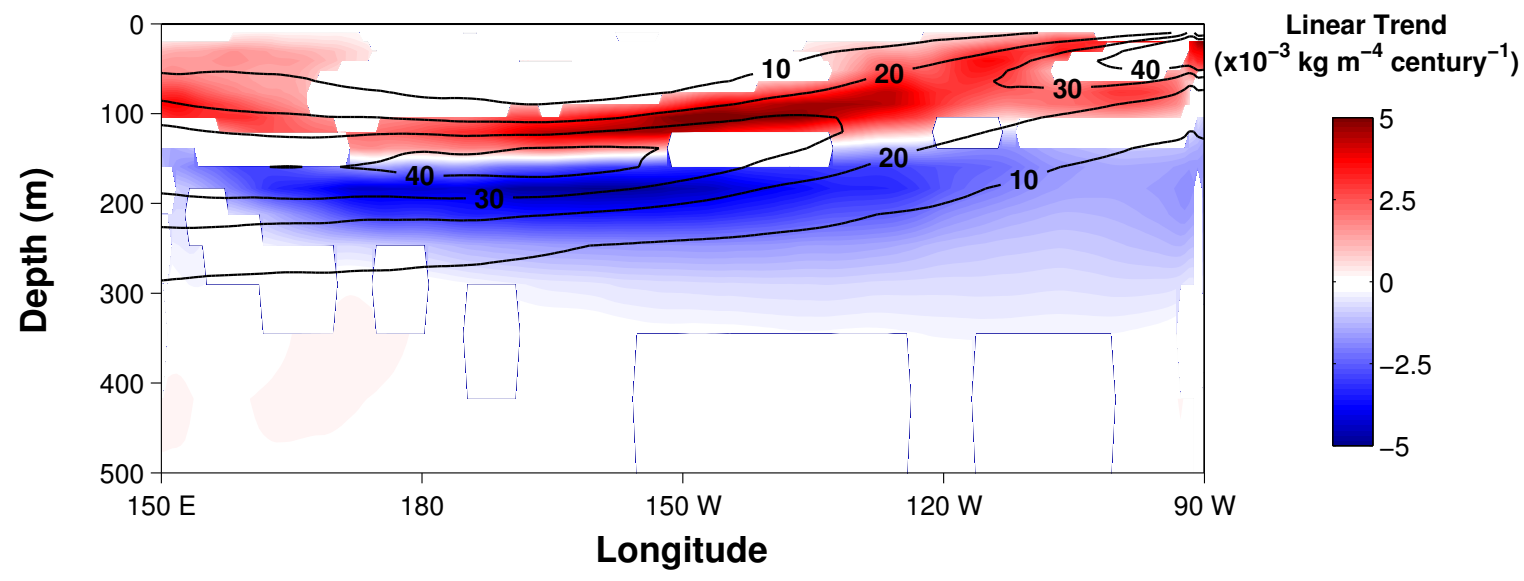

Figure 2-3: Depth-longitude profiles of both average, and long-term trends in a) zonal velocity and b) density gradient along the equatorial Pacific. In a) the solid and dashed black contours indicate the mean state of the EUC and overlying SEC, respectively: zonal velocity (in units: $\mathrm{m} \mathrm{s}^{-1}$ ). Note the sign convention: positive (negative) contours indicate eastward (westward) average or trending movement. In b) the solid black contours indicate the mean state of the vertical density gradient with positive (negative) contours indicating strengthening (weakening) stratification. Velocity and density values were averaged from $2^{\circ} \mathrm{N}-2^{\circ} \mathrm{S}$ prior to calculating trends and the means state over the time span of the SODA record. Regions where the long-term trends were not significant at the $99 \%$ confidence interval were masked out. 

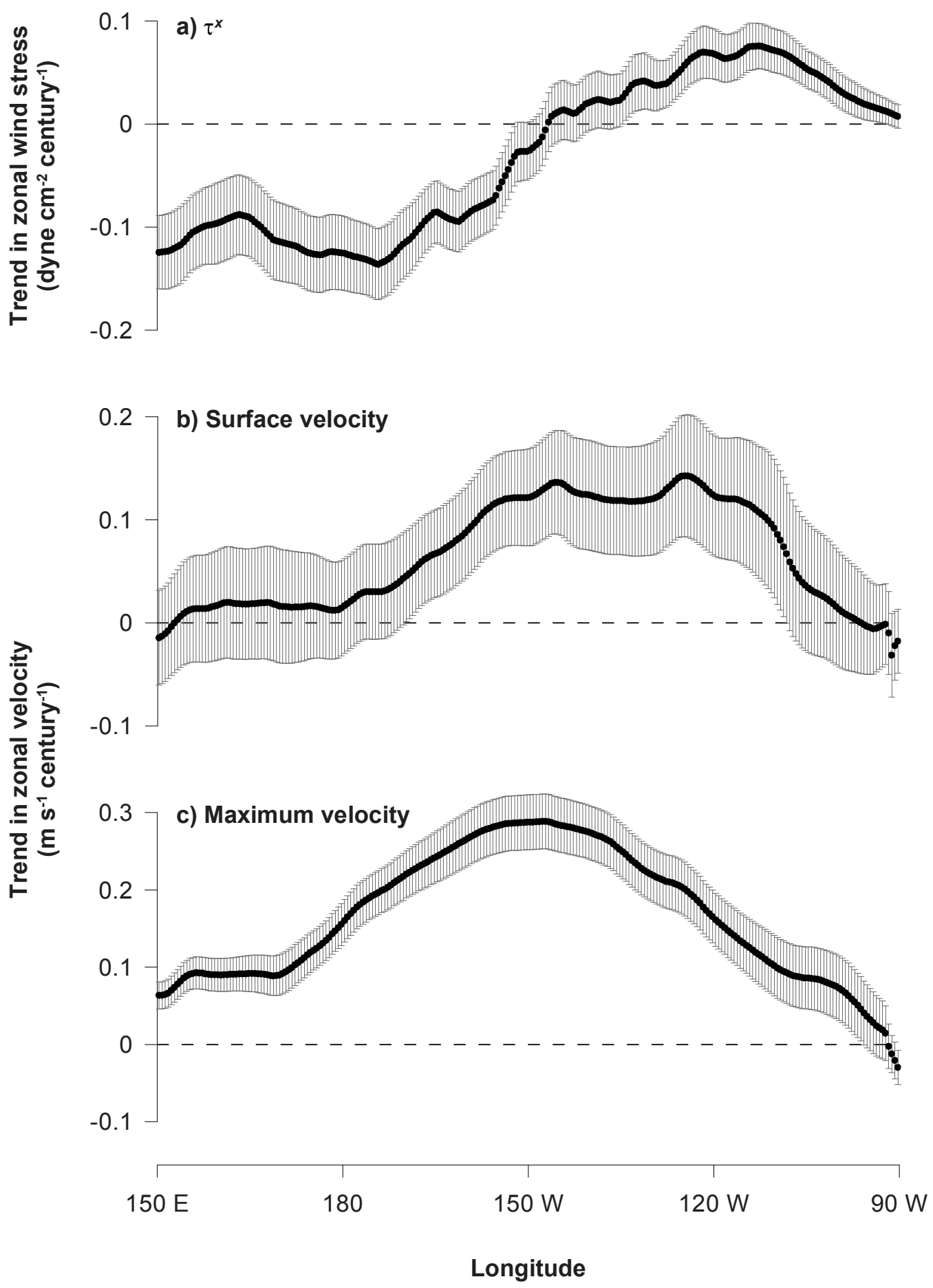

Figure 2-4: Long-term trends by longitude along the equator in a) zonal wind stress, and b) surface and c) maximum (i.e. EUC) zonal velocity. Error bars indicate the $99 \%$ confidence interval of the reported trend. The surface b) is defined as SODA's top depth layer $(\sim 10$ meter), while the EUC domain c) extends through SODA's first 15 sub-surface depth layers ( 10-300 meters). Note the sign convention: positive (i.e. above the ' 0 ' line) values indicate eastward trending movement. 
a) $\tau^{\mathrm{x}}$ (dynes $\mathrm{cm}^{-2}$ )

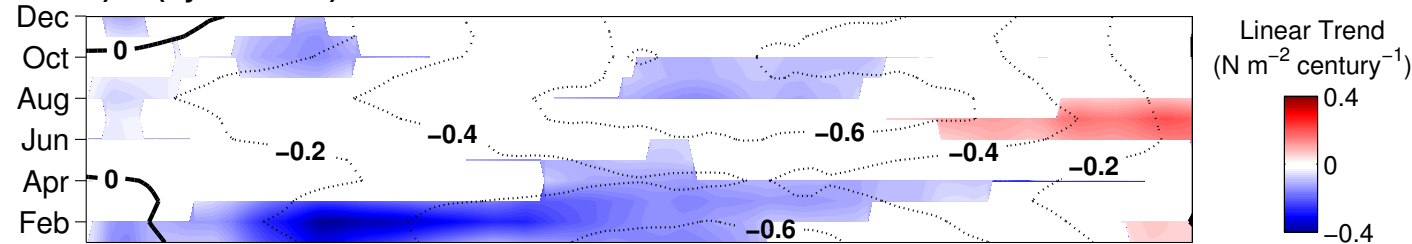

b) Surface velocity $\left(\mathrm{m} \mathrm{s}^{-1}\right)$

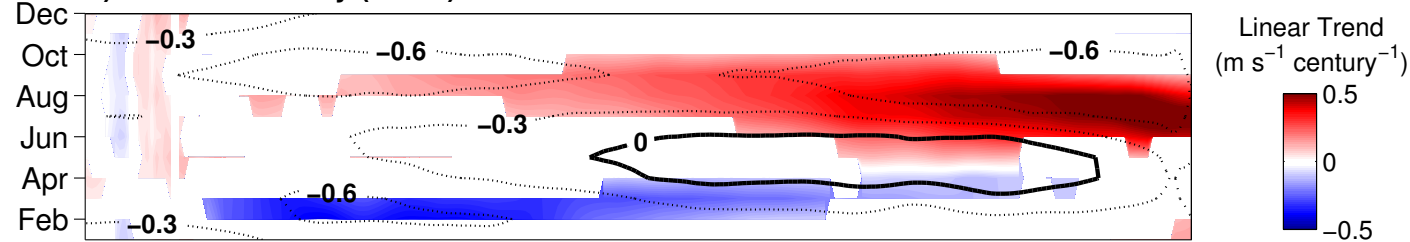

c) $\mathrm{SSH}(\mathrm{m})$

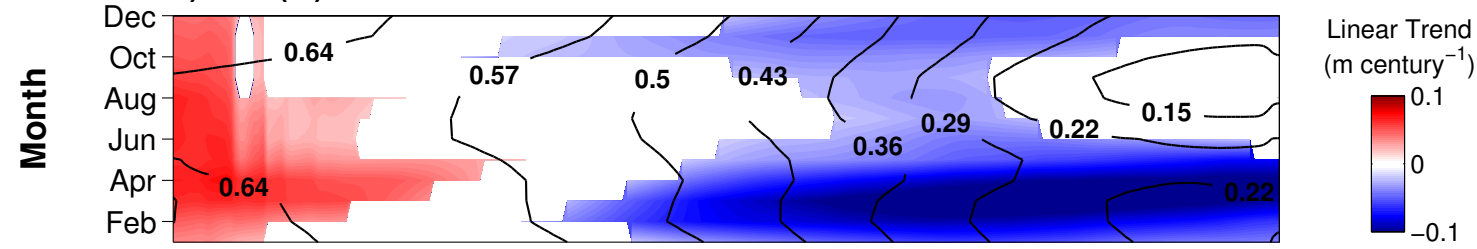

d) Zonal transport (Sv)

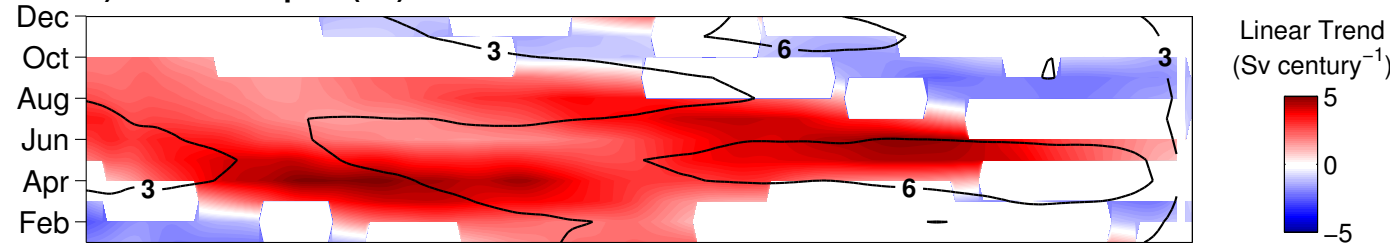

e) Maximum zonal velocity $\left(\mathrm{m} \mathrm{s}^{-1}\right)$

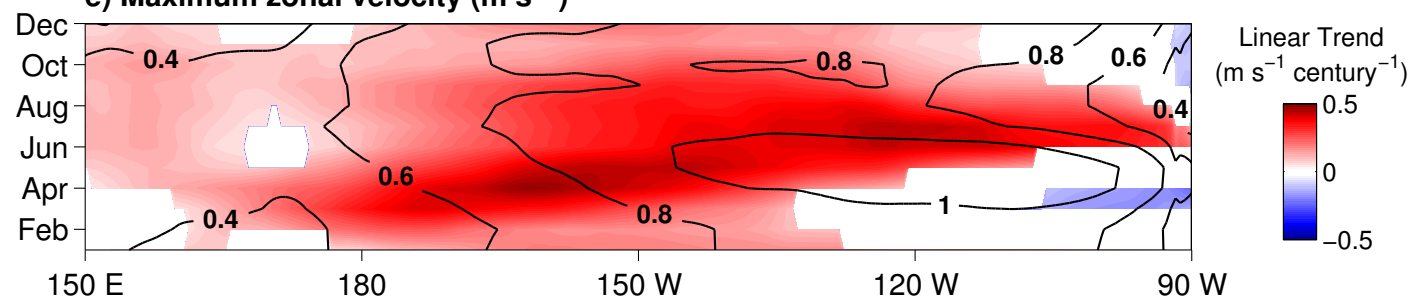

\section{Longitude}

Figure 2-5: Hovmöller diagrams of significant (95\% confidence interval) long-term trends (filled contours) and climatologies (black contours) for a) zonal wind stress, b) surface velocity, c) sea surface height, d) zonal transport and e) maximum zonal (i.e. EUC) velocity on the equator. The surface b) is defined as the top depth layer ( 10 meter), while the transport c) domain extends through the top 20 depth layers in the SODA record (surface to 640 meters) and maximum velocity e) is evaluated between 10 and 300 meters depth. Note the sign convention: positive (negative) contours indicate eastward/upward (westward/downward) average or trending movement. All long-term trends were calculated via linear regression with significance determined at the $95 \%$ confidence interval; regions where the long-term trends were not significant were masked out. 

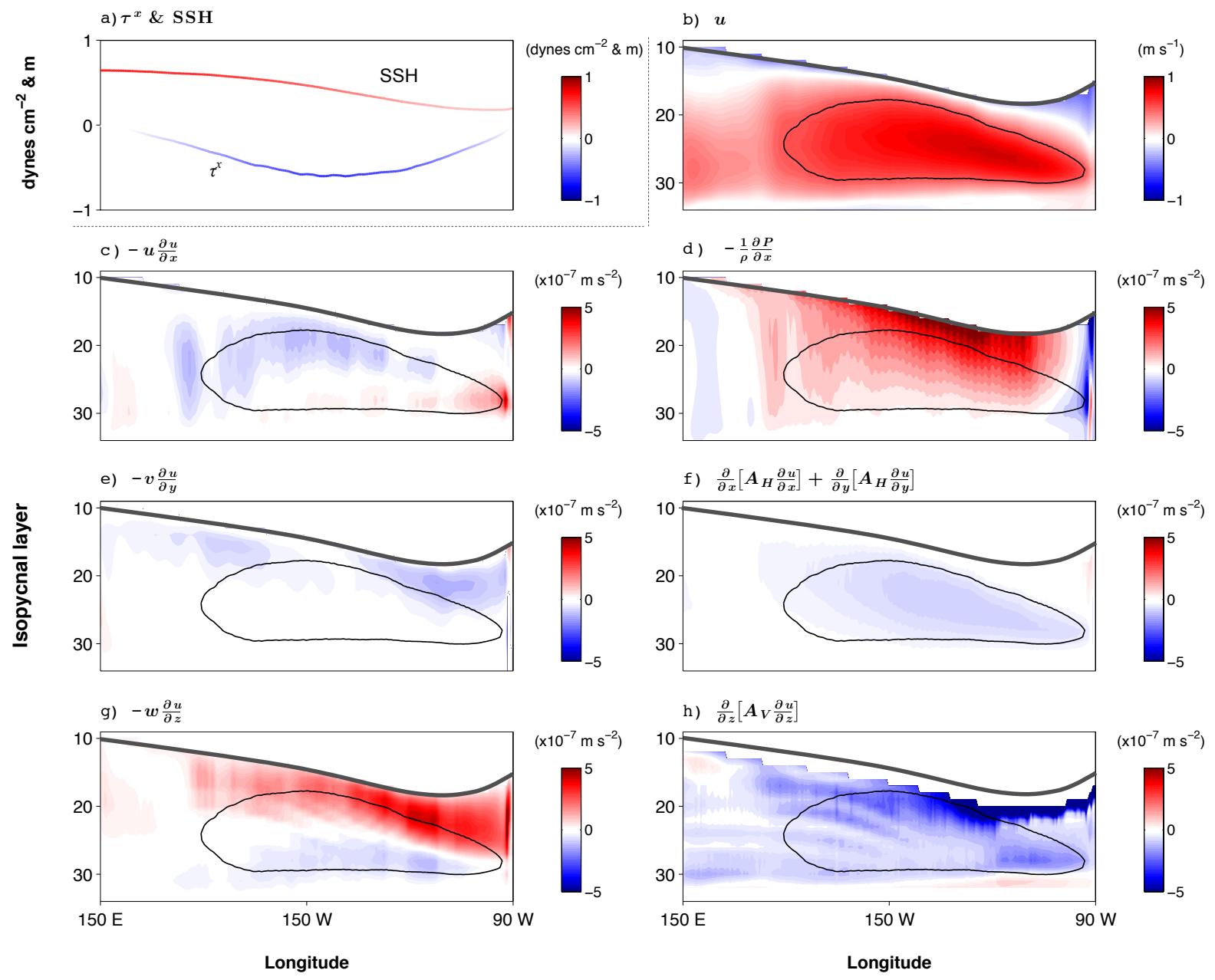

Figure 2-6: Diagrams of the equatorial mean state of a) zonal wind stress and sea surface height, b) zonal velocity and c-h) momentum budget terms. The line color in a) reiterates the $\mathrm{y}$-axis and reflects the magnitude of the wind stress or sea surface height at a given longitude. b-h) are plotted on isopycnals where the solid gray line indicates the surface. The solid black contours are for spatial reference and indicate the region of $.5 \mathrm{~m} \mathrm{~s}^{-1}$ zonal velocity in the SODA time-mean. Note the sign convention: positive (negative) contours indicate eastward (westward) movement or acceleration. 

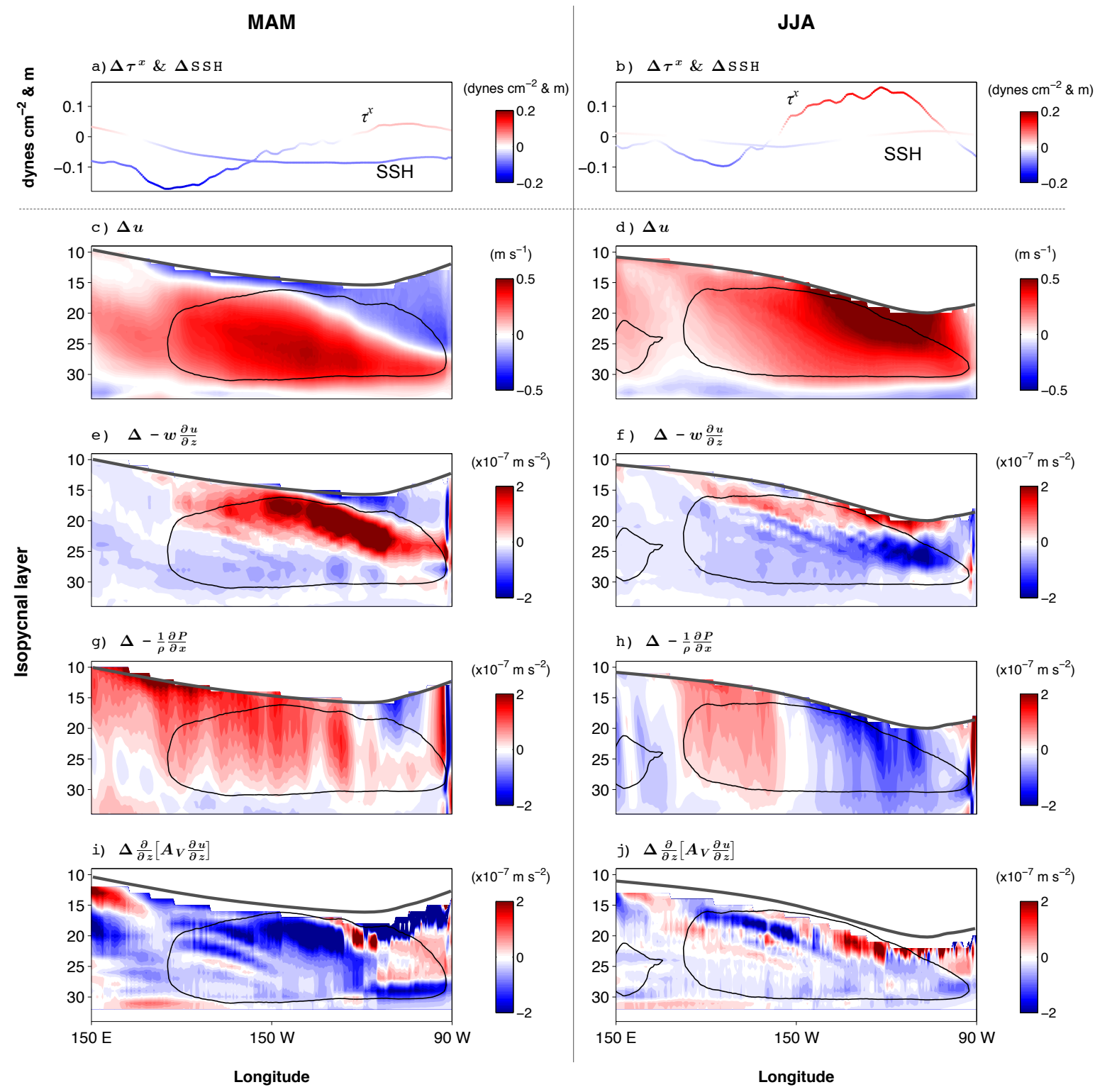

Figure 2-7: Differences between the $4^{\text {th }}$ and $1^{\text {st }}$ quarter of the SODA reanalysis, by season, for: a \& b) zonal wind stress and sea surface height, c \& d) zonal velocity and c-h) select momentum budget terms. The line color in a \& b reflects the magnitude of the wind stress or sea surface height at a given longitude. c-h are plotted on isopycnals where the solid gray line indicates the surface. The solid black contours spatially reference the 4 th quarter, time-mean region of $0.5 \mathrm{~m} \mathrm{~s}^{-1}$ zonal velocity during the respective seasonal subset (i.e. MAM or JJA). Note the sign convention: positive (negative) contours indicate eastward (westward) movement or acceleration. 


\section{Chapter 3}

\section{Calcification by juvenile corals under heterotrophy and ele- vated $\mathrm{CO}_{2}$}

\subsection{Abstract}

Ocean acidification (OA) threatens the existence of coral reefs by slowing the rate of calcium carbonate $\left(\mathrm{CaCO}_{3}\right)$ production of framework-building corals thus reducing the amount of $\mathrm{CaCO}_{3}$ the reef can produce to counteract natural dissolution. Some evidence exists to suggest that elevated levels of dissolved inorganic nutrients can reduce the impact of OA on coral calcification. Here, we investigated the potential for enhanced energetic status of juvenile corals, achieved via heterotrophic feeding, to modulate the negative impact of OA on calcification. Larvae of the common Atlantic golf ball coral, Favia fragum, were collected and reared for 3 weeks under ambient (421 $\mu \mathrm{atm})$ or significantly elevated (1,311 $\mu \mathrm{atm})$ $\mathrm{CO}_{2}$ conditions. The metamorphosed, zooxanthellate spat were either fed brine shrimp (i.e., received nutrition from photosynthesis plus heterotrophy) or not fed (i.e., primarily autotrophic). Regardless of $\mathrm{CO}_{2}$ condition, the skeletons of fed corals exhibited accelerated development of septal cycles and were larger than those of unfed corals. At each $\mathrm{CO}_{2}$ level, fed corals accreted more $\mathrm{CaCO}_{3}$ than unfed corals, and fed corals reared under 1,311 $\mu$ atm $\mathrm{CO}_{2}$ accreted as much $\mathrm{CaCO}_{3}$ as unfed corals reared under ambient $\mathrm{CO}_{2}$. However, feeding did not alter the sensitivity of calcification to increased $\mathrm{CO}_{2} ; \Delta$ calcification $/ \Delta \Omega$ was comparable for fed and unfed corals. Our results suggest that calcification rates of nutritionally replete juvenile corals will decline as OA intensifies over the course of this century. Critically, however, such corals could maintain higher rates of skeletal growth and $\mathrm{CaCO}_{3}$ production under $\mathrm{OA}$ than those in nutritionally limited environments.

Drenkard EJ, Cohen AL, McCorkle DC, de Putron SJ, Starczak VR, Zicht AE. Calcification by juvenile corals under heterotrophy and elevated $\mathrm{CO}_{2}$. Coral Reefs 32: 727-735 (C) 2013 Springer; Permissions License: 3475791406564 


\subsection{Introduction}

The ocean has absorbed $25-30 \%$ of the $\mathrm{CO}_{2}$ emitted by human activities, driving a 0.1 unit decline in surface ocean $\mathrm{pH}$ and a $30 \%$ decrease in carbonate ion concentration $\left(\left[\mathrm{CO}_{3}{ }^{2-}\right]\right)$, a process known as ocean acidification (OA) (Caldeira \& Wickett 2003; Feely et al. 2004). Scleractinian corals build skeletons of aragonite, a polymorph of calcium carbonate $\left(\mathrm{CaCO}_{3}\right)$, and rely on carbonate ions for calcification (Marubini \& Atkinson 1999; Silverman et al. 2007; dePutron2011). The aragonite saturation state ( $\Omega$ ar, $\left.\left[\mathrm{Ca}^{2+}\right]\left[\mathrm{CO}_{3}{ }^{2-}\right] / \mathrm{K}_{\mathrm{sp}(\text { arag })}\right)$ of seawater reflects the thermodynamic tendency for $\mathrm{CaCO}_{3}$ to form $(\Omega>1)$ or dissolve $(\Omega<1)$. Although the tropical oceans where most coral reefs are located are not likely to become under saturated with respect to aragonite $(\Omega a r<1)$ during this century, most experimental studies show that skeletal growth and $\mathrm{CaCO}_{3}$ production by corals are negatively impacted by OA long before aragonite under saturation is reached. On the ecosystem scale, the relative rates of $\mathrm{CaCO}_{3}$ production versus dissolution are critical for coral reefs. If rates of production fall below natural rates of erosion and dissolution, reefs will shift from net accreting to net dissolving structures (Orr et al. 2005; Silverman et al. 2009), diminishing their capacity to provide habitats for marine organisms and to function as effective barriers against waves and tsunamis. Using coral reef community calcification data from the Gulf of Aqaba, Silverman et al. (2009) predicted a global-scale shift from net accreting to net dissolving reefs within the next 60 yrs.

The impact of $\Omega$ ar on calcification by reef organisms has been explored largely in laboratory manipulation experiments, although a handful of in situ datasets provide key insights into the sensitivity of ecosystem-scale calcification to rising $\mathrm{CO}_{2}$ levels (e.g., silverman2007; Shamberger et al. 2011). In general, these studies have shown that both coral and coral reef calcification decline with decreasing $\Omega$ ar (reviewed in Langdon et al. 2000; Hoegh-Guldberg et al. 2007; Fabry et al. 2008; Doney et al. 2009; Pandolfi et al. 2011), but there is considerable variability among populations, species, and studies in the calcification response or sensitivity at a given $\Omega$ ar (summarized in Pandolfi et al. 2011). There is also variability in the absolute rates of calcification among different corals and coral reefs at the same $\Omega$ ar (Shamberger et al. 2011). For example, flume incubations of Hawaiian Porites compressa and Montipora verucosa show a positive, linear relationship between $\Omega$ ar and calcification 
rate (mmol $\mathrm{CaCO}_{3} \mathrm{~m}^{-2} \mathrm{~h}^{-1}$ ) (Langdon and Atkinson 2005). However, de Putron et al. (2011) reported a nonlinear relationship between $\Omega$ ar and calcification by Bermudan Favia fragum and Porites asteroides over a similar range of $\Omega$ ar while Ries et al. (2010) found that Oculina sp. responded only at a treatment $\mathrm{pCO}_{2}$ of $2,800 \mathrm{ppm}(\Omega \mathrm{ar}<1)$ and not at values of $900 \mathrm{ppm}$ and below. On the scale of coral reef communities, different reef ecosystems at the same $\Omega$ ar exhibit significant differences in the rate of net reef calcification. For example, the average net calcification rate of a Red Sea reef was reported as $54.5 \mathrm{mmol}$ $\mathrm{CaCO}_{3} \mathrm{~m}^{-2} \mathrm{~h}^{-1}$ at an average $\Omega$ ar of 3.9 (Silverman et al. 2007), whereas average net calcification rate of the Kaneohe Bay barrier reef on Hawaii was significantly higher (264.2 mmol $\mathrm{CaCO}_{3} \mathrm{~m}^{-2} \mathrm{~h}^{-1}$ ) despite a significantly lower average $\Omega$ ar (2.9) (Shamberger et al. 2011). Multiple environmental and biological factors that influence biogenic calcification on a coral reef could be invoked to explain the variability, but few have been directly tested.

Here, we conducted an experiment in which the nutritional status of zooxanthellate (photosynthesizing) juvenile corals, that were reared under very high and ambient $\mathrm{pCO}_{2}$ was enhanced via heterotrophic feeding. A number of experimental and field studies have demonstrated (Langdon \& Atkinson 2005; Holcomb et al. 2010) or suggested (Atkinson et al. 1995; (Atkinson \& Cuet 2008; Cohen et al. 2009; Shamberger et al. 2011; Edmunds 2011) that elevated dissolved inorganic nutrients (DIN) and/or nutrition via heterotrophic feeding could reduce the impact of elevated $\mathrm{CO}_{2}$ on calcification. We chose to manipulate heterotrophic feeding conditions because the addition of DIN to coral cultures under ambient $\mathrm{CO}_{2}$ can lead to decreased calcification due to a proposed disruption in the coralzooxanthellae symbiosis (Muscatine et al. 1989; Falkowski et al. 1993; Marubini \& Davies 1996), whereas heterotrophic feeding tends to enhance calcification under ambient $\mathrm{CO}_{2}$ conditions (Houlbrèque \& Ferrier-Pagès 2009).

\subsection{Materials and Methods}

\subsubsection{Experimental setup and conditions}

This experiment was conducted at the Bermuda Institute of Ocean Sciences (BIOS) in St. George's, Bermuda. The experimental treatments were two $\mathrm{CO}_{2}$ levels (high and ambient) and two feeding conditions (fed and unfed). The two $\mathrm{pCO}_{2}$ levels were established 
in static 5.5 gallon aquaria filled with serially filtered $(50,5 \mu \mathrm{m})$ seawater prior to the addition of metamorphosed larvae. These conditions were achieved and maintained by directly bubbling air (in the ambient condition) or $\mathrm{CO}_{2}$-enriched air (high $\mathrm{CO}_{2}$ treatment) through micropore bubble "wands" fixed horizontally approximately $5 \mathrm{~cm}$ from the base of each aquarium. A pair of Aalborg mass flow controllers maintained the $\mathrm{CO}_{2}$ concentration of the enriched treatment. The resultant average calculated $\mathrm{pCO}_{2}$ for ambient and high $\mathrm{CO}_{2}$ conditions were $421 \pm 35$ and $1,311 \pm 76 \mu$ atm (mean $\pm \mathrm{SD}$ ), respectively, with corresponding average $\Omega$ ar of $3.66 \pm 0.15$ and $1.63 \pm 0.08$ (mean $\pm \mathrm{SD}$ ), respectively (Table 1). aar of our high $\mathrm{CO}_{2}$ treatments is within range of average global surface ocean Sar predicted by global climate models for the end of this century under the IPCC SRES A2 (Steinacher et al. 2009). Corals in fed treatments were isolated (every night for 2 weeks, every other night for the third week) for $3 \mathrm{~h}$ in $12.5 \mathrm{~cm} \times 12.5 \mathrm{~cm} \times 3 \mathrm{~cm}$ plastic containers filled with seawater from their respective treatment tanks and provided with 24h-old Artemia nauplii (brine shrimp). Feeding took place at night, shortly after lights were switched off to mimic crepuscular feeding and temporal zooplankton abundance observed in local coral reef environments (Lewis \& Price 1975). Unfed corals were not provided nauplii during the 3-week experiment and were not isolated in empty feeding containers.

Each $\mathrm{CO}_{2}$-feeding treatment was conducted in triplicate for a total of twelve aquaria, and all treatments were kept on a 12/12 h light-dark cycle. Fluorescent aquarium lamps maintained maximum light levels of $62 \pm 8 \mu \mathrm{mol}$ quanta $\mathrm{m}^{-2} \mathrm{~s}^{-1}$ (mean $\pm \mathrm{SD}$ ), which were monitored using a LI-COR probe/meter assemblage. The compensation range for $F$. fragum spat on Bermuda is not yet known. We used the low end of known compensation ranges for corals (e.g. 3-233 $\mu \mathrm{mol}$ quanta $\mathrm{m}^{-2} \mathrm{~s}^{-1}$ as reported by Mass et al. 2007) for two reasons. The first was to ensure that corals under elevated $\mathrm{CO}_{2}$ did not bleach (as experienced by Anthony et al. 2009, and the second was to minimize the potential for enhanced photosynthesis to overwhelm or inhibit the feeding-modulated calcification response to elevated $\mathrm{CO}_{2}$. Aquarium temperatures were maintained by in-line chiller/heater systems and monitored every $15 \mathrm{~min}$ (Hobo temperature loggers, Onset Corp.). Average temperature for all treatments over the course of the experiment was $27.6 \pm 0.1{ }^{\circ} \mathrm{C}( \pm \mathrm{SD})$.

Aquarium water was replaced with filtered seawater every week to prevent the build-up of dissolved inorganic nitrogen and other wastes. Prior to removing water from the aquaria, 
we collected discrete water samples for salinity, alkalinity (Alk), and dissolved inorganic carbon (DIC) from every aquarium. Salinity was measured at BIOS with an Autosal salinometer. The Alk/DIC samples were poisoned with mercuric chloride immediately after collection and analyzed using a Marianda VINDTA-3C analysis system at WHOI. Alkalinity was determined by nonlinear curve fitting of data obtained by open-cell titrations, and DIC concentrations were determined by coulometric analysis. Both measurements were standardized using certified reference materials obtained from Dr. A. Dickson (Scripps IO). The $\mathrm{pH}$ (NBS) of each tank was measured every 3-4 d (Orion pH meter and temperaturecompensated electrode) to provide a real-time assessment of tank chemistry. Short-term variations in NBS pH were also assessed on a higher-resolution time scale: for one, 24-h period, by measuring $\mathrm{pH}$ in each aquarium at 3 -h time intervals. The $\mathrm{pH}$ within each tank was maintained within a few hundredths of a $\mathrm{pH}$ unit on both sub-weekly and sub-daily time scales. The carbonate system parameters used to compare treatments $\left(\mathrm{pCO}_{2},\left[\mathrm{HCO}_{3}^{-}\right]\right.$, $\left[\mathrm{CO}_{3}{ }^{2-}\right]$, and $\Omega$ ar) were calculated from the average temperature and discretely sampled salinity, Alk, and DIC data using the CO2SYS program (Lewis \& Wallace 1998; Pelletier et al. 2007) with the constants of Mehrbach et al. (1973) as refit by Dickson \& Millero (1987) (Table 1).

\subsubsection{Coral collection, spawning, and larval settlement}

In July 2010, approximately 1 week prior to anticipated peak larval release date (GoodbodyGringley \& de Putron 2009), we collected 30 mature colonies of the brooding coral, F. fragum, from the Bailey's Bay patch reefs off the northwest Bermudan coast at approximately three to seven meters water depth. Adult colonies were maintained in outdoor flow-through seawater aquaria at BIOS under ambient light and temperature conditions. Parent colonies were kept isolated in glass jars during planula release, which occurred over the course of 6 nights. The live zooxanthellate planulae were collected from all parents and pooled together. Ceramic tiles, approximately $9 \mathrm{~cm}^{2}$, were left out on the reef for 2 months prior to the start of the experiment and further conditioned for larval settlement by scattering bits of freshly collected crustose coralline algae on the tiles. Immediately after collection, actively swimming larvae were transferred to small plastic tubs each containing ceramic tiles and filled with seawater preset to targeted $\mathrm{CO}_{2}$ levels. The tubs had mesh 
lids, allowing for water exchange, while they are submerged in the treatment aquaria. After $48 \mathrm{~h}$, larvae had settled and metamorphosed into primary polyps (at this stage, larvae are "spat"). Spat on tiles were quickly counted, and tiles were pseudo-randomly distributed among the experimental aquaria so that each aquarium had approximately the same number of juvenile corals. Calcification was visible approximately $3 \mathrm{~d}$ after settlement. At the end of 3 weeks $( \pm 1 \mathrm{~d}), 20-50$ primary polyps (including their primary corallite) per treatment were removed from the tiles and frozen at $-80{ }^{\circ} \mathrm{C}$ for analysis of total lipid. Tiles were then removed from treatments and submerged in a $10 \%$ bleach solution for $1 \mathrm{~h}$, which removed the polyp tissue from all of the remaining juvenile corals and exposed the calcified skeleton or primary corallite.

\subsubsection{Quantification of skeletal development, size, and weight}

Each bleached skeleton was digitally photographed, removed from the tile, and weighed using a Metro-Toledo micro-balance (Cohen et al. 2009; de Putron et al. 2011). Images of the spat were examined for skeletal development and size using Spot Imaging software. Length of the primary septa (present in all samples) was used to estimate corallite diameter (i.e., size). The septa are lateral $\mathrm{CaCO}_{3}$ plates that corals accrete in cycles (Fig. 3-1). In our experiment, most spat accreted both primary and secondary septa; the tertiary septa were the last septal cycle accreted by any of the juvenile corals. Rate of skeletal development was defined as percent spat exhibiting tertiary septa, and a two-way ANOVA was used to test for differences in the mean proportion of spat with tertiary septa between the treatments. Feeding treatment and $\mathrm{CO}_{2}$ level were fixed effects (Table A.5.1). Data were arc sin square root transformed to homogenize variances prior to analyses.

To test for differences in mean spat weight and diameter among treatments, a two-way, nested multivariate analysis of variance (MANOVA) was performed on natural log transformed weight data and square root transformed diameter data. Feeding treatment and $\mathrm{CO}_{2}$ levels were fixed main effects, while tank effect was the random factor nested within feeding and $\mathrm{CO}_{2}$ levels (Table A.5.2). Eight univariate $\mathrm{F}$ tests were conducted to test each of the dependent variables. A Bonferonni corrected alpha value of 0.0062 was used to declare significance of F statistics (Table A.5.3). It should be noted that the MANOVA only considers corals that have data for both diameter and weight. If part of a corallite is lost during 
weighing or was attached to coralline algae, both coral size and weight were excluded from the MANOVA analyses. Likewise, if the skeleton was irregularly shaped (i.e., primary septa did not lie in a straight line), the data for those corals were not included. In order to account for any bias that may have resulted from corallite exclusion in the MANOVA, ANOVAs for the dependent variables, weight, and diameter were conducted. These tests considered all data for a given dependent variable to compare with the MANOVA's univariate results.

\subsubsection{Quantification of total lipid and symbiont density}

Ten individual spat from each aquarium were pooled per tissue lipid sample for quantification of total lipid by gravimetric analysis. Pooling was necessary due to the small size of the spat at 3 weeks. Extraction methods follow that of Folch et al. (1957) and Cantin et al. (2007).

Five individual spat from each aquarium were pooled per sample for quantification of symbiont density. Spat were homogenized, centrifuged and the resultant pellet was resuspended in $250 \mu \mathrm{L}$ filtered seawater. Symbionts from multiple (6-9) aliquot sub-samples of the slurry were counted on a known volume hemocytometer grid. Both total tissue lipid and symbiont counts were normalized to the circular area described by the average primary septa length (diameter) for a respective tank and then divided by the number of corals pooled in the sample (i.e., 10 or 5).

Both area-normalized lipid content and symbiont density were compared among levels of $\mathrm{CO}_{2}$ and feeding conditions using two-way ANOVAs with tank as a random factor nested within the $\mathrm{CO}_{2}$ and feeding combinations. Total lipid concentration was transformed to $-1 / \mathrm{x}$ in order to homogenize the variances. All statistical analyses were conducted on SYSTAT.

\subsection{Results}

\subsubsection{Skeletal development}

A significantly higher mean percentage of fed spat accreted tertiary septa (i.e., exhibited a faster rate of development) than did unfed spat (two-way ANOVA p < 0.001; Table A.5.1), but the percentage with tertiary septa did not differ between ambient and high $\mathrm{CO}_{2}$ nor was there a significant interaction between $\mathrm{CO}_{2}$ and feeding (Fig. 3-2a; Table A.5.1). 


\subsubsection{Skeletal size and weight}

Multivariate analysis (MANOVA) of both skeletal weight and diameter indicated that the effect due to $\mathrm{CO}_{2}$ (ambient vs. high) and feeding treatments (fed vs. unfed) were both significant $\left(\mathrm{p}<0.001\right.$; Table A.5.2), but the interaction between feeding and $\mathrm{CO}_{2}$ was not significant. Univariate analyses of the effect of feeding indicate a significant impact on both corallite diameter and weight $(\mathrm{p}<0.001$; Table A.5.3): fed spat accreted larger and heavier skeletons. Likewise, $\mathrm{CO}_{2}$ level significantly impacted corallite weight $(\mathrm{p}<0.001$; Table A.5.3): Skeletons accreted at ambient $\mathrm{CO}_{2}$ were heavier than those raised under high $\mathrm{CO}_{2}$ conditions for a given feeding regime. In contrast, the impact of $\mathrm{CO}_{2}$ on skeletal diameter was not significant (Table A.5.3). The follow-up, independent ANOVAs for weight and diameter, conducted to account for potential bias due to corallite exclusion from the MANOVA, were consistent with the MANOVA's univariate results: Elevated $\mathrm{CO}_{2}$ did not significantly impact the diameter (size) of the skeletons (Figs. 3-2a, 3-3a) but did impact skeletal weight (Figs. 3-2b, 3-3b).

\subsubsection{Lipid and symbiont density}

We did not detect statistically significant differences in area-normalized zooxanthellae density and total tissue lipid content between fed and unfed spat or between $\mathrm{CO}_{2}$ treatments (Fig. 3-4a, b; Table A.5.4). There was significant variability among tanks, which reduced the power to detect differences between $\mathrm{CO}_{2}$ and feeding treatments.

\subsection{Discussion}

Skeletal size and development, rate of $\mathrm{CaCO}_{3}$ production, and energetic status (e.g., total lipid stores and metabolic performance) are key physiological indices of coral health and fitness. High growth rate contributes to juvenile coral survival and successful reef recruitment (Rylaarsdam 1983; Hughes \& Jackson 1985; Vermeij \& Sandin 2008). Linear extension affects a colony's ability to compete for space with algae and reduced skeletal density may affect the structural integrity of the coral holobiont (Hoegh-Guldberg et al. 2007). Further, energetic reserves have been used to model and predict coral colony mortality risk (Anthony et al. 2009). These parameters are sensitive to a number of environmental 
stressors. For example, skeletal growth and calcification tend to decline in corals stressed by elevated temperatures (e.g., Rodrigues \& Grottoli 2006; Cooper et al. 2008; Cantin et al. 2010) or eutrophication (Marubini \& Atkinson 1999), and bleaching can result in rapid depletion of energetic reserves (e.g., Grottoli et al. 2004; Rodrigues \& Grottoli 2007). Given anticipated (Kleypas et al. 1999) and experimentally observed (e.g., Langdon \& Atkinson 2005) declines in coral calcification due to acidification, it has been suggested that OA may increase the energetic demands of $\mathrm{CaCO}_{3}$ production (Cohen et al. 2009; Holcomb et al. 2010; Ries 2011).

In this study, OA induced by significantly elevated levels of $\mathrm{CO}_{2}$ had no effect on the rate of development of septal cycles and skeletal diameter (size) nor could we detect a significant effect on area-normalized total tissue lipid content and symbiont density of juvenile corals reared from planulae larvae (Figs. 3-2, 3-4). Conversely, fed juveniles reared under elevated $\mathrm{CO}_{2}$ conditions $(\sim 5$ times preindustrial) exhibited faster tertiary septa development and had larger skeletons than unfed juveniles reared under ambient $\mathrm{CO}_{2}$ levels $(\sim 1.5$ times preindustrial). Thus, for newly settled corals of this species, OA may have little, if any, impact on lateral size and septal development, whereas factors that impact food availability or a coral's ability to acquire food could affect these aspects of postsettlement growth.

Heterotrophic feeding also significantly impacted the rate of $\mathrm{CaCO}_{3}$ production (as measured by total corallite weight). Under both ambient and elevated $\mathrm{CO}_{2}$ conditions, fed corals produced significantly more $\mathrm{CaCO}_{3}$ over the 3 -week experimental period than unfed corals (Fig. 3-2c). At $421 \mu \mathrm{atm} \mathrm{CO}_{2}$ fed corals produced $55 \%$ more $\mathrm{CaCO}_{3}$ than unfed corals; at $1,311 \mu$ atm $\mathrm{CO}_{2}$ the difference was $68 \%$. Thus, under significantly elevated $\mathrm{CO}_{2}$ conditions, fed spat develop faster, grow bigger, and weigh more than unfed spat. This suggests that, to the extent that young corals affect the reef $\mathrm{CaCO}_{3}$ budget, nutritionally enhanced juveniles contribute more $\mathrm{CaCO}_{3}$ than those that are nutritionally restricted and subjected to the same $\mathrm{CO}_{2}$ conditions. Remarkably, fed juveniles subjected to significantly elevated $\mathrm{CO}_{2}$ also develop faster and grow larger than unfed corals reared under ambient $\mathrm{CO}_{2}$ conditions, and their rate of $\mathrm{CaCO}_{3}$ production are comparable. Therefore, by implication, nutritionally replete corals could perform better under OA than corals that are nutritionally restricted.

Nevertheless, our results indicate that feeding does not mitigate the impact of OA on 
calcification by juvenile corals. In both fed and unfed groups, skeletal weight decreased, by $23.0 \pm 2.9$ and $28.9 \pm 0.1 \%$, respectively ( $\sim 8-14 \%$ per unit drop in omega), under elevated $\mathrm{CO}_{2}$. This change is equivalent to that observed by dePutron2011 for both acid addition and $\mathrm{CO}_{2}$ manipulation experiments with the same Favia species, although it is significantly less than the $80 \%$ drop predicted by the Langdon and Atkinson model (2005).

A number of studies report increased calcification by corals under heterotrophic feeding (e.g., Houlbrèque \& Ferrier-Pagès 2009), which is consistent with the observations in this study. However, our data show that the negative effect of OA on calcification persists under conditions of heterotrophic feeding. In our study, feeding did not change the sensitivity of calcification to OA. This suggests that nutritional enhancement via heterotrophic feeding did not change the mechanics of the calcification response to OA in our corals. Although Edmunds (2011) concluded that heterotrophic feeding does mitigate the impact of elevated $\mathrm{CO}_{2}$ on juvenile Porites calcification, both the fed and unfed Porites corals in his experiment exhibited reduced biomass-corrected calcification under elevated $\mathrm{CO}_{2}$, which is consistent with our result for Favia. Indeed, Edmunds' (2011) result lends support to our observation that the sensitivity of calcification response to elevated $\mathrm{CO}_{2}$ is consistent between fed and unfed corals. In other words, heterotrophic feeding does not mitigate the effect of OA on coral calcification.

That heterotrophic feeding does not mitigate the impact of OA on juvenile coral differs from the results of Langdon \& Atkinson (2005) and Holcomb et al. (2010) who reported significant modulation of the $\mathrm{CO}_{2}$ effect with inorganic nutrient enrichment. In these studies, addition of ammonium, and of nitrates, phosphates, and iron, respectively, did reduce calcification sensitivity to OA. In the experiments of Langdon \& Atkinson (2005), nutrient addition enhanced symbiont photosynthesis (photosynthesis was not measured in Holcomb et al. (2010). We were not able to detect a significant impact on area-normalized symbiont densities due to feeding in our experiments (Fig. 3-4b). This observation is different from that reported by a number of previous studies (Muscatine et al. 1989; Titlyanov et al. 2000a; Titlyanov et al. 2000b; Titlyanov et al. 2001; Houlbrèque et al. 2003; Houlbrèque et al. 2004) and may be due to our lack of statistical power to detect a significant feeding effect. Alternatively, although our corals were fully zooxanthellate at the time of settlement, the impact of feeding on symbiont densities might differ between young corals and 
the mature colonies used in other experiments. Endosymbiont density is only one component of the coral holobiont's photosynthetic capacity and is not a substitute for direct measurements of photosynthesis (e.g., Langdon \& Atkinson 2005) because the performance of individual symbionts is still unknown. Therefore, we can only speculate that the difference between our result (i.e., no significant difference detected in symbiont density or reduction in sensitivity to $\mathrm{CO}_{2}$ due to feeding) and that of Langdon \& Atkinson (2005), that is, DIN enrichment resulting in enhanced photosynthesis and reduced sensitivity to $\mathrm{CO}_{2}$, suggest a role for symbiont photosynthesis in the coral calcification response to OA. From our data, it does not appear that simply enhancing coral energetic status (in this case, via feeding) alters calcification sensitivity to OA. However, photosynthesis and heterotrophy may impact coral calcification via different mechanisms. If this is the case, then the impact of OA on calcification when photosynthesis is enhanced might differ from the impact of OA on calcification when feeding is enhanced. Incidentally, it should be noted that the degree to which feeding impacted calcification rates in this study may be specific to our relatively low-light regime and test species and could therefore differ among organisms subjected to higher light environments.

Additionally, fast-growing, prereproductive juvenile corals might respond to feeding differently from adults, which were used in both the Langdon \& Atkinson (2005) and Holcomb et al. (2010) experiments. Adult corals may allocate the extra energy from heterotrophic feeding differently from juveniles. To investigate whether our juvenile corals were storing the extra energy from heterotrophic feeding as lipid reserve, or using it to build new tissue or skeleton, we averaged total tissue lipid content over circular surface area (Fig. 3-4b). We could not detect a significant difference in the amount of lipid accumulated by the corals in the different feeding regimes. This suggests that, in this particular experiment, the fed coral spat did not store the extra energy acquired from feeding but rather used it for growth. Whether or not mature colonies in experimental conditions and on actual reefs respond to food availability the same way, that is, by investing in tissue growth rather than lipid storage, is yet to be tested.

Our results show that healthy, nutritionally replete spat of the Atlantic coral, F. fragum, can sustain high rates of calcification under significantly elevated $\mathrm{CO}_{2}$. However, enhanced nutritional status does not render these corals immune to OA. This has important impli- 
cations for the ability of corals and coral reefs to maintain levels of growth and $\mathrm{CaCO}_{3}$ production required to sustain reef ecosystems through increasingly hostile conditions over the twentyfirst century.

\subsection{Acknowledgements}

The authors are grateful to Rebecca Belastock (WHOI) for DIC/Alk analyses. We also thank Ms. Hannah Barkley (WHOI), Ms. Kascia White (BIOS) and Mr. Mark Dowar (BIOS) for assistance with fieldwork and experiment maintenance, and Dr Neal Cantin (WHOI) for assistance with laboratory procedures. This project was funded by NSF OCE-1041106 and NSF OCE-1041052, a WHOI winter intern fellowship to A. Zicht made possible by the A. V. Davis Foundation and support from the MIT/WHOI Bermuda Biological Station for Research Fund. We thank the three anonymous reviewers and the editor for suggestions that greatly improved the manuscript. 


\subsection{References}

Anthony KRN, Hoogenboom MO, Maynard JA, Grottoli AG, Middlebrook R (2009) Energetics approach to predicting mortality risk from environmental stress: a case study of coral bleaching. Functional Ecology 23: 539-550

Atkinson M, Carlson B, Crow G (1995) Coral growth in high-nutrient, low-pH seawater: a case study of corals cultured at the Waikiki Aquarium, Honolulu, Hawaii. Coral Reefs 14: $215-223$

Atkinson MJ, Cuet P (2008) Possible effects of ocean acidification on coral reef biogeochemistry: topics for research. Marine Ecology Progress Series 373: 249-256

Caldeira K, Wickett ME (2003) Oceanography: Anthropogenic carbon and ocean pH. Nature 425: $365-365$

Cantin NE, Negri AP, Willis BL (2007) Photoinhibition from chronic herbicide exposure reduces reproductive output of reef-building corals. Marine Ecology Progress Series 344: $81-93$

Cantin NE, Cohen AL, Karnauskas KB, Tarrant AM, McCorkle DC (2010) Ocean Warming Slows Coral Growth in the Central Red Sea. Science 329: 322-325

Cohen AL, McCorkle DC, de Putron S, Gaetani GA, Rose KA (2009) Morphological and compositional changes in the skeletons of new coral recruits reared in acidified seawater: Insights into the biomineralization response to ocean acidification. Geochemistry, Geophysics, Geosystems 10: Q07005

Cooper TF, De'ath G, Fabricius KE, Lough JM (2008) Declining coral calcification in massive Porites in two nearshore regions of the northern Great Barrier Reef. Global Change Biology 14: 529-538

Dickson A, Millero F (1987) A comparison of the equilibrium constants for the dissociation of carbonic acid in seawater media. Deep Sea Research Part A Oceanographic Research Papers 34: 1733 - 1743

Doney SC, Fabry VJ, Feely RA, Kleypas JA (2009) Ocean Acidification: The Other $\mathrm{CO}_{2}$ Problem. Annual Review of Marine Science 1: 169-192, pMID: 21141034

Edmunds J Peter (2011) Zooplanktivory ameliorates the effects of ocean acidification on the reef coral Porites spp. Limnology and Oceanography 56: 2402-2410

Fabry VJ, Seibel BA, Feely RA, Orr JC (2008) Impacts of ocean acidification on marine fauna and ecosystem processes. ICES Journal of Marine Science: Journal du Conseil 65: $414-432$

Falkowski PG, Dubinsky Z, Muscatine L, McCloskey L (1993) Population Control in Symbiotic Corals: Ammonium ions and organic materials maintain the density of zooxanthellae. BioScience 43: 606-611 
Feely RA, Sabine CL, Lee K, Berelson W, Kleypas J, Fabry VJ, Millero FJ (2004) Impact of Anthropogenic $\mathrm{CO}_{2}$ on the $\mathrm{CaCO}_{3}$ System in the Oceans. Science 305: 362-366

Folch J, Lees M, Sloane Stanley GH (1957) A simple method for the isolation and purification of total lipides from animal tissues. Journal of Biological Chemistry 226: 497-509

Goodbody-Gringley G, de Putron SJ (2009) Planulation patterns of the brooding coral Favia fragum (Esper) in Bermuda. Coral Reefs 28: 959-963

Grottoli A, Rodrigues L, Juarez C (2004) Lipids and stable carbon isotopes in two species of Hawaiian corals, Porites compressa and Montipora verrucosa, following a bleaching event. Marine Biology 145: 621-631

Hoegh-Guldberg O, Mumby PJ, Hooten AJ, Steneck RS, Greenfield P, Gomez E, Harvell CD, Sale PF, Edwards AJ, Caldeira K, Knowlton N, Eakin CM, Iglesias-Prieto R, Muthiga N, Bradbury RH, Dubi A, Hatziolos ME (2007) Coral Reefs Under Rapid Climate Change and Ocean Acidification. Science 318: 1737-1742

Holcomb M, McCorkle DC, Cohen AL (2010) Long-term effects of nutrient and $\mathrm{CO}_{2}$ enrichment on the temperate coral Astrangia poculata (Ellis and Solander, 1786). Journal of Experimental Marine Biology and Ecology 386: 27-33

Houlbrèque F, Ferrier-Pagès C (2009) Heterotrophy in Tropical Scleractinian Corals. Biological Reviews 84: 1-17

Houlbrèque F, Tambutté E, Ferrier-Pagès C (2003) Effect of zooplankton availability on the rates of photosynthesis, and tissue and skeletal growth in the scleractinian coral Stylophora pistillata. Journal of Experimental Marine Biology and Ecology 145-166

Houlbrèque F, Tambutté E, Allemand D, Ferrier-Pagès C (2004) Interactions between zooplankton feeding, photosynthesis and skeletal growth in the scleractinian coral Stylophora pistillata. Journal of Experimental Biology 207: 1461-1469

Hughes TP, Jackson JBC (1985) Population Dynamics and Life Histories of Foliaceous Corals. Ecological Monographs 55: 141-166

Kleypas JA, Buddemeier RW, Archer D, Gattuso JP, Langdon C, Opdyke BN (1999) Geochemical Consequences of Increased Atmospheric Carbon Dioxide on Coral Reefs. Science 284: $118-120$

Langdon C, Atkinson MJ (2005) Effect of elevated $\mathrm{pCO}_{2}$ on photosynthesis and calcification of corals and interactions with seasonal change in temperature/irradiance and nutrient enrichment. Journal of Geophysical Research: Oceans 110: C09S07

Langdon C, Takahashi T, Sweeney C, Chipman D, Goddard J, Marubini F, Aceves H, Barnett H, Atkinson MJ (2000) Effect of calcium carbonate saturation state on the calcification rate of an experimental coral reef. Global Biogeochemical Cycles 14: 639-654

Lewis E, Wallace DWR (1998) Program Developed for $\mathrm{CO}_{2}$ System Calculations. ORNL/CDIAC-105, Carbon Dioxide Information Analysis Center Oak Ridge Natl Lab, US Dept of Energy, Oak Ridge, TN 
Lewis JB, Price WS (1975) Feeding mechanisms and feeding strategies of Atlantic reef corals. Journal of Zoology 176: 527-544

Marubini F, Atkinson MJ (1999) Effects of lowered pH and elevated nitrate on coral calcification. Marine Ecology Progress Series 188: 117-121

Marubini F, Davies P (1996) Nitrate increases zooxanthellae population density and reduces skeletogenesis in corals. Marine Biology 127: 319-328

Mass T, Einbinder S, Brokovich E, Shashar N, Vago R, Erez J, Dubinsky Z (2007) Photoacclimation of Stylophora pistillata to light extremes: metabolism and calcification. Marine Ecology Progress Series 334: 93-102

Mehrbach C, Culberson CH, Haeley JE, Pytkowicz RM (1973) Measurement of apparent dissociation constants of carbonic acid in seawater at atmospheric pressure. Limnology and Oceanography 18: 897-907

Mucci A (1983) The solubility of calcite and aragonite in seawater at various salinities, temperatures, and one atmosphere total pressure. American Journal of Science 283: 780799

Muscatine L, Falkowski PG, Dubinsky Z, Cook PA, McCloskey LR (1989) The Effect of External Nutrient Resources on the Population Dynamics of Zooxanthellae in a Reef Coral. Proceedings of the Royal Society of London B Biological Sciences 236: 311-324

Orr JC, Fabry VJ, Aumont O, Bopp L, Doney SC, Feely RA, Gnanadesikan A, Gruber N, Ishida A, Joos F, Key RM, Lindsay K, Maier-Reimer E, Matear R, Monfray P, Mouchet A, Najjar RG, Plattner GK, Rodgers KB, Sabine CL, Sarmiento JL, Schlitzer R, Slater RD, Totterdell IJ, Weirig MF, Yamanaka Y, Yool A (2005) Anthropogenic ocean acidification over the twenty-first century and its impact on calcifying organisms. Nature 437: 681-686

Pandolfi JM, Connolly SR, Marshall DJ, Cohen AL (2011) Projecting Coral Reef Futures Under Global Warming and Ocean Acidification. Science 333: 418-422

Pelletier G, Lewis E, Wallace DWR (2007) CO2sys.xls: A Calculator for the $\mathrm{CO}_{2}$ System in Seawater for Microsoft Excel/VBA. Washington State Department of Ecology, Olympia, WA/ Brookhaven National Laboratory, Upton, NY, USA

de Putron S, McCorkle D, Cohen A, Dillon A (2011) The impact of seawater saturation state and bicarbonate ion concentration on calcification by new recruits of two Atlantic corals. Coral Reefs 30: 321-328

Ries J, Cohen A, McCorkle D (2010) A nonlinear calcification response to $\mathrm{CO}_{2}$-induced ocean acidification by the coral Oculina arbuscula. Coral Reefs 29: 661-674

Ries JB (2011) A physicochemical framework for interpreting the biological calcification response to $\mathrm{CO}_{2}$-induced ocean acidification. Geochimica et Cosmochimica Acta 75: 4053 $-4064$

Rodrigues LJ, Grottoli A (2007) Energy reserves and metabolism as indicators of coral recovery from bleaching. Limnology and Oceanography 52: 1874-1882 
Rodrigues LJ, Grottoli AG (2006) Calcification rate and the stable carbon, oxygen, and nitrogen isotopes in the skeleton, host tissue, and zooxanthellae of bleached and recovering Hawaiian corals. Geochimica et Cosmochimica Acta 70: 2781-2789

Rylaarsdam KW (1983) Life histories and abundance patterns of colonial corals on Jamaican reefs. Marine Ecology Progress Series 13: 249-260

Shamberger K, Feely R, Sabine C, Atkinson M, DeCarlo E, Mackenzie F, Drupp P, Butterfield D (2011) Calcification and organic production on a Hawaiian coral reef. Marine Chemistry 127: 64-75

Silverman J, Lazar B, Erez J (2007) Community metabolism of a coral reef exposed to naturally varying dissolved inorganic nutrient loads. Biogeochemistry 84: 67-82

Silverman J, Lazar B, Cao L, Caldeira K, Erez J (2009) Coral reefs may start dissolving when atmospheric $\mathrm{CO}_{2}$ doubles. Geophysical Research Letters 36: L05 606

Steinacher M, Joos F, Frölicher TL, Plattner GK, Doney SC (2009) Imminent ocean acidification in the Arctic projected with the NCAR global coupled carbon cycle-climate model. Biogeosciences 6: 515-533

Titlyanov EA, Bil' K, Fomina I, Titlyanova TV, Leletkin VA, Eden N, Malkin A, Dubinsky Z (2000a) Effects of dissolved ammonium addition and host feeding with Artemia salina on photoacclimation of the hermatypic coral Stylophora pistillata. Marine Biology 137: $463-472$

Titlyanov EA, Tsukahara J, Titlyanova TV, Leletkin VA, van Woesik R, Yamazato K (2000b) Zooxanthellae population density and physiological state of the coral Stylophora pistillata during starvation and osmotic shock. Symbiosis 303-322

Titlyanov EA, Titlyanova TV, Yamazato K, van Woesik R (2001) Photo-acclimation of the hermatypic coral Stylophora pistillata while subjected to either starvation or food provisioning. Journal of Experimental Marine Biology and Ecology 257: 163-181

Vermeij MJA, Sandin SA (2008) Density-dependent settlement and mortality structure the earliest life phases of a coral population. Ecology 89: 1994-2004 


\begin{tabular}{|c|c|c|c|c|c|c|c|c|}
\hline Treatment & $\begin{array}{c}\text { Salinity } \\
(\mathrm{psu} \pm \mathrm{SD})\end{array}$ & $\begin{array}{c}\text { Alkalinity } \\
\left(\mu \text { eq } \mathrm{kg}^{-1} \pm \mathrm{SD}\right)\end{array}$ & $\begin{array}{c}\mathrm{DIC} \\
\left(\mu \mathrm{mol} \mathrm{kg}{ }^{-1} \pm \mathrm{SD}\right)\end{array}$ & $\begin{array}{c}\mathrm{pCO}_{2} \\
(\mu \mathrm{atm} \pm \mathrm{SD})\end{array}$ & $\begin{array}{c}\mathrm{pH} \\
(\text { total } \pm \mathrm{SD})\end{array}$ & $\begin{array}{c}{\left[\mathrm{HCO}_{3}^{-}\right]} \\
\left(\mu \mathrm{mol} \mathrm{kg}{ }^{-1} \pm \mathrm{SD}\right)\end{array}$ & $\begin{array}{c}{\left[\mathrm{CO}_{3}{ }^{2-}\right]} \\
\left(\mu \mathrm{mol} \mathrm{kg}{ }^{-1} \pm \mathrm{SD}\right)\end{array}$ & $\begin{array}{c}\Omega \mathrm{ar} \\
( \pm \mathrm{SD})\end{array}$ \\
\hline $\begin{array}{c}\text { Ambient } \mathrm{CO}_{2}, \\
\text { Fed }\end{array}$ & $37.6 \pm 0.3$ & $2,332 \pm 22$ & $2,012 \pm 33$ & $443 \pm 40$ & $8.00 \pm 0.03$ & $1,775 \pm 40$ & $225 \pm 9$ & $3.55 \pm 0.16$ \\
\hline $\begin{array}{c}\text { Ambient } \mathrm{CO}_{2}, \\
\text { Unfed }\end{array}$ & $37.4 \pm 0.3$ & $2,325 \pm 20$ & $1,984 \pm 16$ & $398 \pm 4$ & $8.04 \pm 0.00$ & $1,735 \pm 13$ & $239 \pm 3$ & $3.77 \pm 0.03$ \\
\hline $\begin{array}{l}\text { High } \mathrm{CO}_{2}, \\
\quad \text { Fed }\end{array}$ & $37.0 \pm 0.2$ & $2,324 \pm 9$ & $2,213 \pm 16$ & $1,344 \pm 78$ & $7.59 \pm 0.02$ & $2,077 \pm 17$ & $100 \pm 4$ & $1.59 \pm 0.06$ \\
\hline $\begin{array}{l}\text { High } \mathrm{CO}_{2}, \\
\text { Unfed }\end{array}$ & $37.0 \pm 0.2$ & $2,326 \pm 23$ & $2,207 \pm 21$ & $1,278 \pm 70$ & $7.61 \pm 0.02$ & $2,069 \pm 20$ & $105 \pm 5$ & $1.66 \pm 0.08$ \\
\hline
\end{tabular}

Table 3.1: Average $( \pm \mathrm{SD})$ seawater chemistry for given experimental treatment conditions. Average temperature $\left(27.6{ }^{\circ} \mathrm{C}\right)$ and measured salinity, alkalinity, and DIC were used to calculate $\mathrm{pCO}_{2}, \mathrm{pH},\left[\mathrm{HCO}_{3}{ }^{-}\right],\left[\mathrm{CO}_{3}{ }^{2-}\right]$, and aragonite saturation state $(\Omega$ ar) for each aquarium using CO2SYS (Lewis \& Wallace 1998). We used Dickson \& Millero (1987)'s dissociation constants from the refit of Mehrbach et al. (1973) and the aragonite solubility of Mucci (1983). We computed mean treatment condition from the average values of each treatment's three replicate tanks. One anomalous pair of alkalinity/DIC values from one aquarium was omitted from the calculations for the ambient, fed aquaria 


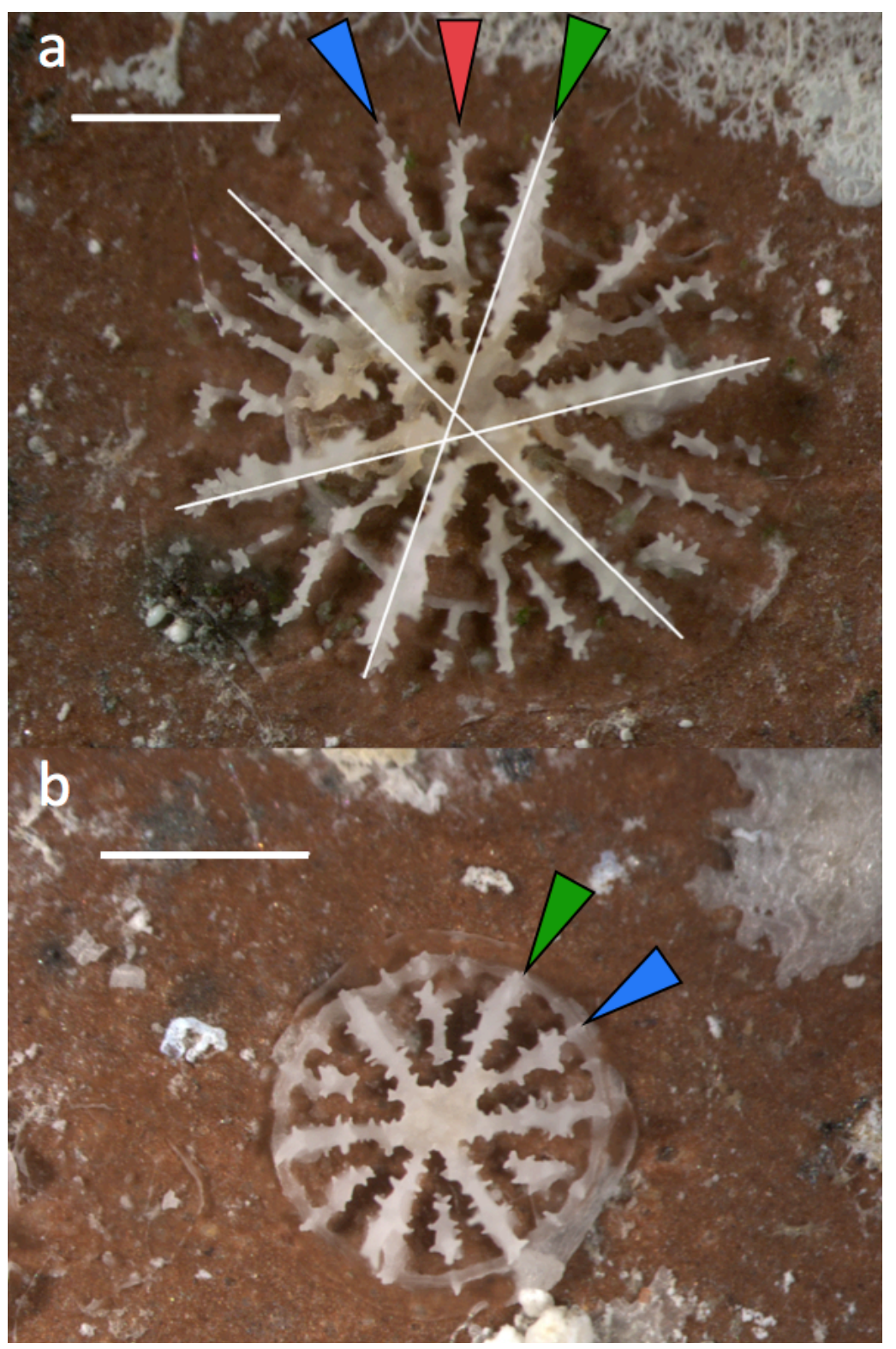

Figure 3-1: Three-week-old F. fragum corallites from (a) fed corals and (b) unfed corals in this study. In both images, the different septal stages are identified. Primary septa are indicated with green arrows, secondary with blue, and tertiary with red. White lines along the primary septa in (a) indicate corallite diameter used to determine lateral size. Scale bars are $1 \mathrm{~mm}$ 

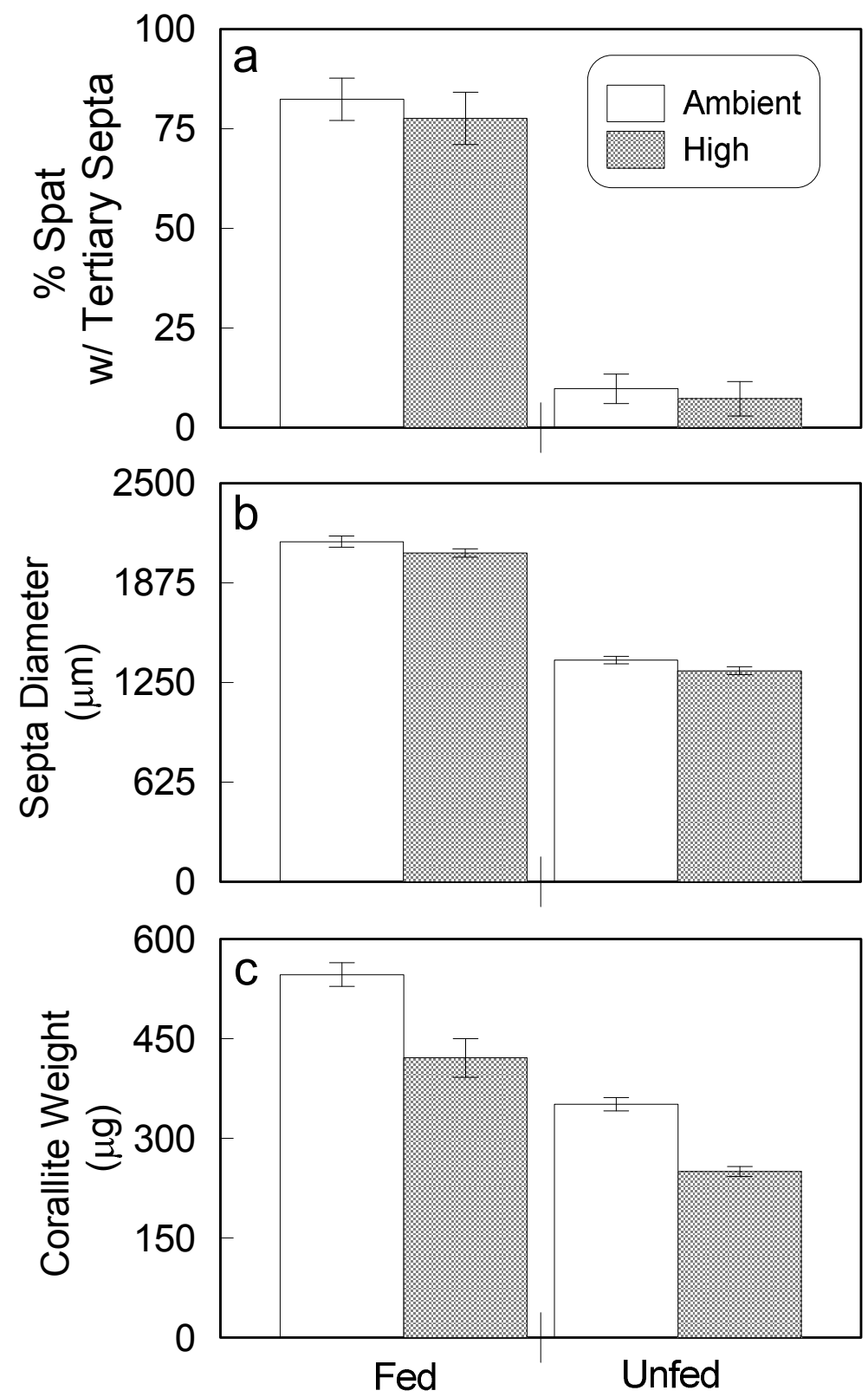

Feeding Treatment

Figure 3-2: The percent of spat in a given treatment exhibiting tertiary septa (a), the diameter of primary septa (b), and the corallite weight (c) of fed and unfed spat. Bars indicate the average across three replicate tanks, which are themselves averaged across the number of samples for a given tank. Gray bars indicate high $\mathrm{CO}_{2}$ and white bars indicate ambient $\mathrm{CO}_{2}$ conditions. Error bars represent \pm one standard error among replicate tanks 

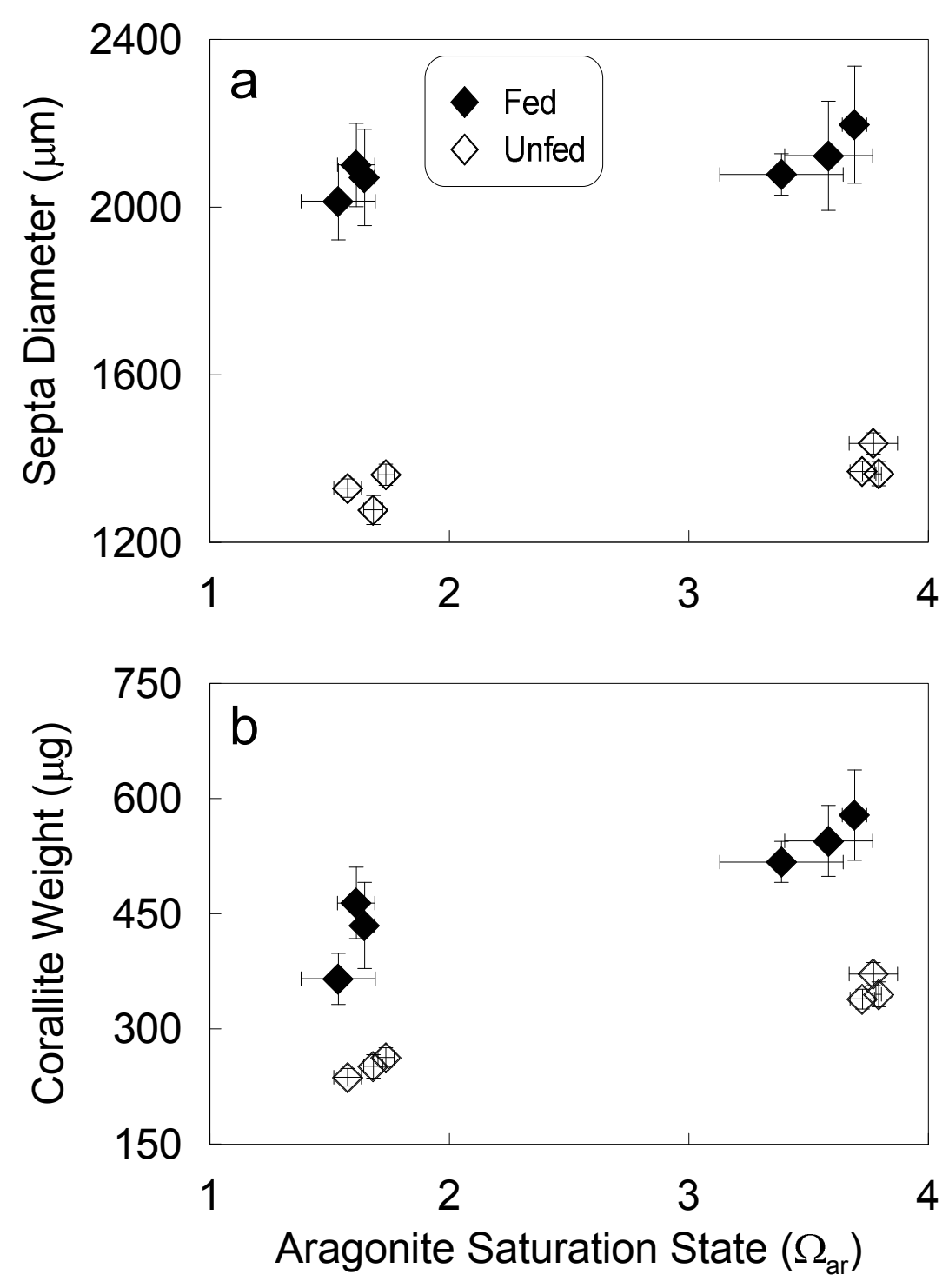

Figure 3-3: Corallite diameter (a) and total corallite weight (b) versus $\Omega$ ar observed in fed (filled diamonds) and unfed (empty diamonds) corals. Error bars represent \pm one standard error for replicate analyses of each tank 

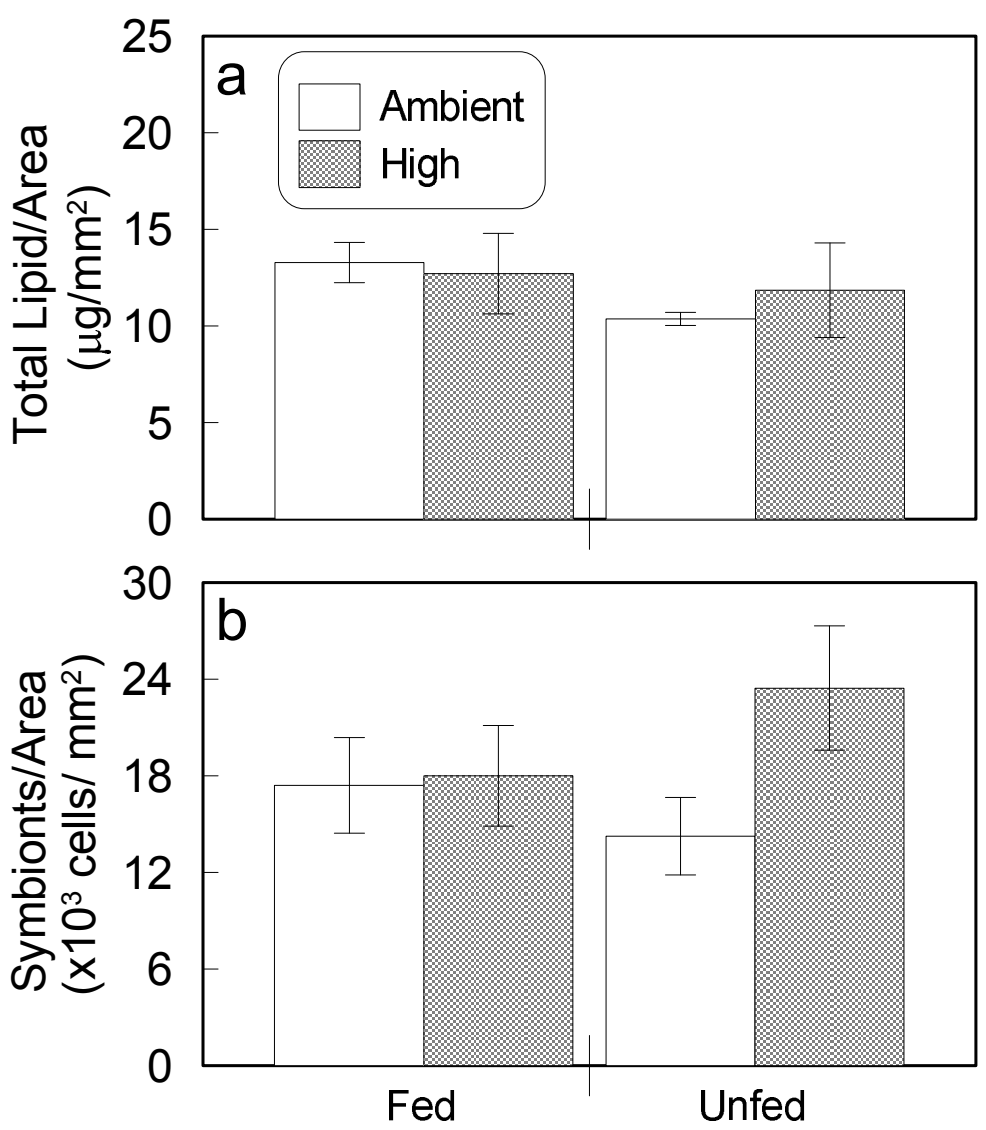

Feeding Treatment

Figure 3-4: Area-normalized total tissue lipid weight per spat in fed and unfed corals. Bars indicate the average across three replicate tanks, which are themselves averaged across the number of samples for a given tank. Gray bars indicate high $\mathrm{CO}_{2}$ and white bars indicate ambient $\mathrm{CO}_{2}$ conditions. Error bars represent \pm one standard error among replicate tanks. Although these plots depict the raw data from the experiment, the ANOVA was performed on the transformed data, which met the criteria for homogeneity of variance 


\section{Chapter 4}

\section{Calcification by juvenile corals under varied light and elevated $\mathrm{CO}_{2}$}

\subsection{Abstract}

Ocean acidification $(\mathrm{OA})$ caused by rising levels of atmospheric carbon dioxide $\left(\mathrm{CO}_{2}\right)$ reduces the concentration of carbonate ions $\left(\left[\mathrm{CO}_{3}{ }^{2-}\right]\right)$ in seawater. Multiple laboratory and field studies have shown that rates of calcification by reef-building corals decline when seawater $\left[\mathrm{CO}_{3}{ }^{2-}\right]$ decreases, raising concerns about the impact of OA on the future survival of coral reef ecosystems. Nevertheless, other studies show that the sensitivity of coral calcification to OA can be modulated by other factors. Specifically, elevated concentrations of dissolved inorganic nutrients (DIN) have been shown to reduce (Holcomb et al. 2010) or eliminate entirely (Langdon \& Atkinson 2005) the impact of OA on calcification. Further, zooxanthellate corals receiving additional nourishment via heterotrophy can grow larger and produce as much $\mathrm{CaCO}_{3}$ under significantly elevated $\mathrm{CO}_{2}$ as conspecifics relying solely on autotrophy and reared under ambient $\mathrm{CO}_{2}$ conditions (Drenkard et al. 2013).

Building on these results, we investigated the impact of light on coral calcification under OA conditions. In two separate experiments conducted over two consecutive years, we quantified total calcification, lipid content, zooxanthellate densities and photosynthetic pigments in juveniles of the Atlantic golf ball coral Favia fragum, reared under a range of $\mathrm{CO}_{2}$ and light levels.

Experiment 1 was conducted in 2011 under higher light conditions $(220 \mu$ mol quanta $\mathrm{m}^{-2} \mathrm{~s}^{-1}$ ) across four levels of $\mathrm{CO}_{2}$ : ambient (420 ppm) and 1060, 1720, and $2660 \mathrm{ppm}$ corresponding to Rarvalues of $3.5,2,1.5$ and 1.1 respectively. Corals were reared for 3 weeks post-recruitment and either fed with Artemia brine shrimp, or unfed. We found no statistically significant effect of $\mathrm{CO}_{2}$ on calcification. Conversely, feeding had a significant effect on calcification with fed corals producing significantly more $\mathrm{CaCO}_{3}$ than unfed corals regardless of $\mathrm{CO}_{2}$ treatment.

Experiment 2 was conducted in 2012 under higher $\left(220 \mu \mathrm{mol}\right.$ quanta $\left.\mathrm{m}^{-2} \mathrm{~s}^{-1}\right)$ and 
lower $\left(60 \mu \mathrm{mol}\right.$ quanta $\left.\mathrm{m}^{-2} \mathrm{~s}^{-1}\right)$ light conditions and two $\mathrm{CO}_{2}$ levels: ambient (430 ppm) and $1920 \mathrm{ppm}$, corresponding to $\Omega$ ar values of 3.7 and 1.5 respectively. Corals were reared for two weeks postrecruitment and not fed. We found no effect of $\mathrm{CO}_{2}$ or light level on calcification.

We combined these data with those generated in our previous (2010) experiment (Drenkard et al. 2013, Chapter 2) to compare daily calcification rates, total lipid content, zooxanthellate densities and photosynthetic pigments (chlorophyll $a$ density) of unfed juveniles only, reared under ambient versus elevated $\mathrm{CO}_{2}$ and light. This cross-year comparison revealed that corals reared under higher light levels had consistently lower chlorophyll a densities, higher total lipid content and reduced calcification sensitivity to elevated $\mathrm{CO}_{2}$ compared with corals raised under lower light levels. That corals in higher light conditions have higher total lipid content is consistent with higher rates of zooxanthellate photosynthesis, and implies that the reduction in $\mathrm{CO}_{2}$ sensitivity of corals under higher light conditions is linked to photosynthesis.

Our interpretation is consistent with previous studies that show enhancement of photosynthesis by elevated DIN reduces sensitivity of coral calcification to OA. Lack of sensitivity of total lipid to elevated $\mathrm{CO}_{2}$ argues against a simple energetics explanation. Conversely, heterotrophic feeding produces larger, heavier corallites (this study), but does not reduce sensitivity to OA (Drenkard et al. 2013). That fed corals are as sensitive to OA as unfed corals also argues against a simple energetics explanation. While the mechanism(s) by which enhanced heterotrophy and enhanced autotrophy modulate the impact of OA on coral calcification remain unclear, our results indicate that corals in nutritionally replete and/or optimal light environments will likely fare better under $21^{\text {st }}$ century ocean acidification than those in oligotrophic and/or low light environments. 


\subsection{Introduction}

Ocean acidification (OA), caused by ocean absorption of atmospheric $\mathrm{CO}_{2}$, shifts the balance of dissolved inorganic carbon (DIC) species in seawater, resulting in a reduction in the concentration of carbonate ions. Scleractinian corals utilize carbonate ions to produce aragonite (a polymorph of calcium carbonate; $\mathrm{CaCO}_{3}$ ) skeletons that serve as both the structural scaffolding and an important source of $\mathrm{CaCO}_{3}$ for coral reef ecosystems. The thermodynamic tendency for spontaneous nucleation and growth of aragonite is described by the saturation state $\left(\Omega\right.$ ar, $\left.\left[\mathrm{Ca}^{2+}\right]\left[\mathrm{CO}_{3}{ }^{2-}\right] / \mathrm{K}_{\mathrm{sp}(\text { arag })}\right)$, with net $\mathrm{CaCO}_{3}$ dissolution occurring when seawater is under saturated (i.e., $\Omega<1$ ). However, overwhelming experimental and field evidence indicate that coral calcification is adversely affected by declining $\Omega$ ar well before seawater conditions reach undersaturation (e.g., Gattuso et al. 1998, reviewed in Langdon et al. 2000, Hoegh-Guldberg et al. 2007, Fabry et al. 2008, Doney et al. 2009, Pandolfi et al. 2011). Nevertheless, there is considerable variability among experiments regarding the level of $\mathrm{CO}_{2}$ at which $\Omega$ ar begins to affect calcification (summarized in Pandolfi et al. 2011), the degree of calcification sensitivity to OA (e.g., Langdon \& Atkinson 2005), and, among field studies, differences in calcification rates among organisms and ecosystems under similar $\Omega$ ar conditions as well as differences in the extrapolated/ projected $\Omega$ ar at which these systems will transition to states of net $\mathrm{CaCO}_{3}$ dissolution (e.g., Silverman et al. 2007 vs. Shamberger et al. 2011; Fabricius et al. 2011 vs. Shamberger et al. 2014).

Recent studies suggest that coral nutrition and energetic status may contribute to these inconsistencies in coral calcification response to OA (e.g., Cohen \& Holcomb 2009, Ries et al. 2009, Holcomb et al. 2010, Edmunds 2011, Rodolfo-Metalpa et al. 2011, Holcomb et al. 2012, Drenkard et al. 2013). Calcification is generally considered a metabolically costly process, although the cost of calcification as a percent of the coral's energy budget remains unknown. For instance, molecular evidence, which demonstrates the presence of ATPase $\mathrm{Ca}^{2+}-\mathrm{H}^{+}$pumps within the tissue layer that interfaces with the calcifying space (Zoccola et al. 2004), supports the hypothesis that corals actively invest energetic resources to remove protons from the calcifying fluid, effectively raising the $\mathrm{pH}, \Omega$ ar, and increasing aragonite precipitation (McConnaughey \& Whelan 1997, Cohen \& McConnaughey 2003). Corals obtain the nutrition they would need to fuel this process both by consuming the 
photosynthate produced by, and transferred from their algal endosymbionts (i.e., zooxanthellae), and through heterotrophic feeding. Other active mechanisms have also been invoked to explain corals' accelerated $\mathrm{CaCO}_{3}$ precipitation (e.g., discussed in Chalker \& Taylor 1975) and numerous studies show that corals can produce more $\mathrm{CaCO}_{3}$ when maintained under elevate nutritional conditions such as sufficient levels of photosynthetically available radiation (PAR) and heterotrophic feeding (e.g., reviewed in Gattuso et al. 1999, Ferrier-Pagès et al. 2011).

Thus it has been proposed that the elevated nutritional or energetic status of the coral host may mitigate the calcification response to OA (e.g., Atkinson et al. 1995; Atkinson \& Cuet 2008; Cohen \& Holcomb 2009). Several studies employing different forms of nutritional

enhancement have been conducted. In general, corals reared under elevated $\mathrm{CO}_{2}$ combined with elevated levels of inorganic nutrients (Langdon \& Atkinson 2005, Holcomb et al. 2010) and PAR (Suggett et al. 2013, Chan \& Connolly 2013) exhibited reduced sensitivity to $\mathrm{CO}_{2}$. Conversely, in feeding experiments, fed corals produce more $\mathrm{CaCO}_{3}$ than unfed corals but exhibit similar sensitivity to $\mathrm{CO}_{2}$ (Edmunds 2011, Drenkard et al. 2013).

Here we present our results from two experiments in which we manipulated the nutritional status of juvenile zooxanthellate corals reared under ambient and elevated $\mathrm{CO}_{2}$ conditions. The goal of these experiments was to investigate further the role of nutrition in modulating the calcification response to OA. In these experiments, the nutritional or energetic status of the coral host was manipulated in two ways, by heterotrophic feeding and by elevating light levels in order to stimulate photosynthesis. First, we describe the results of the two experiments conducted in two different years $(2011,2012)$. We also present new chlorophyll $a$ data from the 2010 experiment (Chapter 1) We then combine the results of both experiments with those of the 2010 experiment to investigate the role of light in the coral calcification response to OA.

\subsection{Materials and Methods}

\subsubsection{Experimental setup and conditions}

We conducted two experiments at the Bermuda Institute of Ocean Sciences (BIOS) in St. George's, Bermuda during the summers of 2011 and 2012 in which juvenile corals 
were reared from settlement ( $\sim 24$ hrs post-release) over a range of $\mathrm{CO}_{2}$ and light levels. Aquarium maintenance and the methods used to achieve desired $\mathrm{CO}_{2}$ levels are identical to those reported in Drenkard et al. (2013). We regularly monitored the $\mathrm{CO}_{2}$ concentration of the ambient and $\mathrm{CO}_{2}$-enriched air that was bubbled into the tanks using a Qubit infrared $\mathrm{CO}_{2}$ analyzer.

All tanks were maintained on a 12/12 h light-dark cycle using the same low/high output fluorescent aquarium lamps for all three experiments; PAR was measured with a LI-COR probe/meter. In order to maintain consistent aquarium temperatures, all tanks were placed in water baths, which were thermally regulated by in-line chiller/heater systems and individual aquarium temperatures were recorded at 15-minute intervals using $\mathrm{HOBO}$ temperature loggers (Onset Corp.); average treatment temperatures are reported in Table 4.1.

Prior to weekly water replacements (performed to prevent excessive accumulation of nitrogenous and other waste products), we collected discrete samples for salinity, alkalinity (Alk), dissolved inorganic carbon (DIC), and dissolved inorganic nitrogen and phosphorous from each aquarium. Salinity samples were analyzed at BIOS (Autosal salinometer) and Alk/DIC samples, which were poisoned with mercuric chloride during collection, were analyzed at WHOI (Marianda VINDTA-3C system); the specific analytical methods to determine these values and calculations for carbonate system parameters $\left(\left[\mathrm{HCO}_{3}{ }^{-}\right],\left[\mathrm{CO}_{3}{ }^{2-}\right]\right.$, and Sar; reported in Table 4.1) are the same as in Drenkard et al. (2013). The nutrient samples for these two experiments and the previous 2010 experiment were analyzed at the WHOI Nutrient Analytical Facility and the results are reported in Table 4.2.

\section{Conditions Specific to 2011 Experiment}

The partial pressure (mean $\pm \mathrm{SD}$ ) of the four $\mathrm{CO}_{2}$ levels bubbled into the experimental tanks were $420 \pm 10 \mathrm{ppm}, 1060 \pm 10 \mathrm{ppm}, 1720 \pm 90 \mathrm{ppm}$, and $2660 \pm 30 \mathrm{ppm}$ (Table 4.1). Each $\mathrm{CO}_{2}$-feeding treatment was conducted in triplicate, for a total of 24 aquaria. Crepuscular feeding schedule follows that outlined for our 2010 experiment (Drenkard et al. 2013). Average PAR was $215 \pm 21 \mu \mathrm{mol}$ quanta $\mathrm{m}^{-2} \mathrm{~s}^{-1}$ (mean $\pm \mathrm{SD}$ ); the experiment was conducted for three weeks. 


\section{Conditions Specific to 2012 Experiment}

The two $\mathrm{pCO}_{2}$ conditions were $430 \pm 20 \mathrm{ppm}$ and $1920 \pm 20 \mathrm{ppm}$ for the ambient and high $\mathrm{CO}_{2}$ treatments respectively (Table 4.1). It is important to note that although the Qubit measurements differed considerably between experiments, these values indicate approximate $\mathrm{CO}_{2}$ concentration of the gas bubbled through the tanks and often higher than the equilibrated value achieved in treatment tanks. Indeed, the saturation state levels achieved for high and ambient $\mathrm{CO}_{2}$ tanks were generally comparable across experimental year (Table 4.1). The averaged PAR for the low and higher light conditions were $38 \pm 5$ and $227 \pm 19 \mu \mathrm{mol}$ quanta $\mathrm{m}^{-2} \mathrm{~s}^{-1}$ (mean $\pm \mathrm{SD}$ ) respectively and there were four replicates for each $\mathrm{CO}_{2}$-light treatment for a total of 16 aquaria. The experiment was conducted for two weeks.

\subsubsection{Coral collection, spawning and larval settlement}

Each year, we collected mature colonies of the Atlantic brooding coral, F. fragum from the Bailey's Bay patch reefs off the northwest Bermudan coast in early July, approximately one week prior to anticipated peak larval release date (Goodbody-Gringley \& de Putron 2009). These colonies were kept in outdoor flow-through seawater aquaria where they were exposed to ambient light and temperature conditions. During larval release, parent colonies were isolated in glass jars in order to keep released planulae contained; all zooxanthellate planulae spawned on a given day where pooled together for settlement.

For both experiments, we followed the settlement and sampling procedures explicitly outlined in Drenkard et al. (2013): collected larvae were settled on reef-conditioned terracotta tiles in seawater that was at pre-established $\mathrm{CO}_{2}$ treatment levels. Following a 48-hour settlement period, tiles with metamorphosed larvae (referred to as "spat") were allocated to experimental tanks such that each aquarium contained approximately the same number of juvenile corals.

At the experiments' conclusions, we collected (i.e. removed from the tiles) primary polyps for various soft tissue analyses, including total lipid (10 spat per sample), symbiont density (1 spat per sample), and pigment (5 spat per sample). Samples collected for total lipid and symbiont densities were frozen at $-80{ }^{\circ} \mathrm{C}$ and $-20^{\circ} \mathrm{C}$ respectively. The samples used 
for pigment (specifically chlorophyll) analysis were originally intended for genetic studies and thus frozen at $-20{ }^{\circ} \mathrm{C}$ in RNAlater (QIAGEN). Although this is not the preferred method for storing pigment samples, samples from all years were subjected to the same storage conditions. Therefore, while the exact value for pigment densities may be underestimates, the relative comparisons among treatment conditions are informative. Tiles with corals remaining were placed in $10 \%$ bleach/ seawater solution in order to remove the tissue, thus exposing the primary corallite for skeletal analyses.

\subsubsection{Quantification and analysis of skeletal size and weight}

Skeletal parameters were measured following the methods in Drenkard et al. (2013), with corallite size defined as the primary septa (i.e., $\mathrm{CaCO}_{3}$ plates extending radial from the coral) diameter, and skeletal weight being the total corallite $\mathrm{CaCO}_{3}$ mass. All statistical analyses were performed using MYSTATß) (Systat Software, Inc. Chicago, IL, USA). A t-test was conducted in order to test for the effect due experimental year (i.e., differences in experimental duration; 2wks vs. 3wks) between unfed 2011 and 2012 corals.

In order to compare skeletal weight data within and across experiments, each coral was age-normalized by the number of days it was subjected to experimental conditions. Additionally, given the strong correlation between corallite size and weight $\left(\mathrm{R}^{2}=0.89\right.$; Fig.1), average age-normalized skeletal weight for a given tank was normalized by the average septal diameter for that tank (treatment tank is the lowest common denominator for these data because we were not able to obtain skeletal weight data for every corallite for which we had

a size measurement and vice versa). Bonferonni corrected alpha values of 0.0071 and 0.0014 were used to declare $\mathrm{F}$ statistic significance with $95 \%$ and $99 \%$ confidence, respectively (Appendix B.9).

\section{Skeletal Analyses}

We conducted two, two-way ANOVAs to test for the effect of $\mathrm{CO}_{2}$ and feeding on 1) skeletal size and 2) age- and size-normalized skeletal weight. 


\section{Skeletal Analyses}

We conducted two, two-way ANOVAs to test for the effect of $\mathrm{CO}_{2}$ and light on 1) skeletal size and 2) age- and size-normalized skeletal weight.

\section{Inter-year Skeletal Analyses}

In order to compare experimental results from different experimental years but under similar light regimes, we conducted two, two-way ANOVAs testing for the effect of $\mathrm{CO}_{2}$ and experimental year on age- and size-normalized skeletal weight. These comparisons considered only unfed corals corals reared under HL (2011/2012) or LL (2010/2012) conditions (Fig. 4-5).

\subsubsection{Quantification and analysis of total lipid, symbiont, and chlorophyll density}

We use coral total tissue lipid as an indicator of stored energetic reserves available to the organism to withstanding environmental stressors (i.e., OA), and symbiont and chlorophyll density as a measure of the coral host's potential to utilize light as a form of nutrition. As in Drenkard et al. (2013), we followed the extraction methods outlined by Folch et al. (1957) and Cantin et al. (2007) for gravimetric quantification of total lipid content, and extracted coral symbionts via homogenization, centrifugation and re-suspension in order to conduct counts on a known-volume hemocytometer grid. Samples for chlorophyll analysis were homogenized and sonicated in 100\% Methanol in order to release pigments. These samples were spiked with canthaxanthin standard in order to track and adjust for pigment decay/loss. These samples were analyzed using HPLC techniques outlined in Wright et al. (1991) with results in units of ng of chlorophyll $a$. We assumed that chlorophyll $a$ degradation products resulted from the preservation process. This is based on the fact that a set of coral samples from the 2010 experiment were flash frozen and exhibited no detectable amount of pheophytin or chlorophyll $a$ degradation products (data not shown). Therefore, we corrected and included these degradation product concentrations in the total reported amount of chlorophyll $a$.

Data for tissue lipid, symbiont counts, and chlorophyll mass were age-adjusted based on 
the average number of days each coral in the pooled sample was subjected to experimental conditions, and then normalized to the circular area defined by the average primary septa length (diameter) for a respective tank. It should be noted that tissue date, unlike skeletal weight data, were area-normalized because, unlike the $\mathrm{CaCO}_{3}$ in these juvenile corals' skeletons, which is concentrated in the septa, the coral's tissue is distributed over the entire area of the corallite. Only the 2012 samples were analyzed in the full complement of treatment conditions; a subset of the 2010 and 2011 samples (unfed corals) are presented for comparison to 2012 results.

\section{Tissue Analyses}

We conducted three, two-way ANOVAs to test for the effect due to $\mathrm{CO}_{2}$ and light on area and age-normalized tissue lipid content, zooxanthellae densities and chlorophyll $a$ concentrations. Age- and area- normalizes total lipid was transformed to $-1 / \mathrm{x}$ to homogenize variances.

\section{Inter-year Tissue Analyses}

We conducted two, two-way ANOVAs to test for the effect of $\mathrm{CO}_{2}$ and experimental year on each tissue parameter: Age- and area- normalized tissue lipid, symbiont density and chlorophyll content. Bonferonni corrected alpha values of 0.0083 and 0.0017 were used to declare significance of F-statistics with the $95 \%$ and $99 \%$ confidence, respectively (Appendix B.9).

To further investigate the role of light-stimulated photosynthesis on the organic hostsymbiont holobiont, we conducted inter-year comparisons, similar to those for skeletal weight, for total tissue lipid, and symbiont and chlorophyll densities.

\subsection{Results}

\subsubsection{Skeletal Size and Weight}

\section{Results}

Fed corals were significantly $(\mathrm{p}<0.01)$ larger and produced significantly $(\mathrm{p}<0.05)$ more $\mathrm{CaCO}_{3}$ than their unfed counterparts; there was no detectable effect due to $\mathrm{CO}_{2}$ or 
the interaction between $\mathrm{CO}_{2}$ and feeding on skeletal size or weight (Fig 4-2a \& 4-3a).

\section{Results}

Among 2012 samples, there was no significant effect due to $\mathrm{CO}_{2}$ light, or the interaction between these two factors on either skeletal size or weight (Figs.4-2b \& 4-3b). Unfed corals from the 2 -wk experiment were significantly $(\mathrm{p}<0.01)$ smaller in size than unfed corals from the 3-wk experiment conducted in 2011 (Fig. 4-1a \& 4-1b).

\section{Inter-year Comparison Results}

Age-and size-normalized skeletal weight show a significant effect due to $\mathrm{CO}_{2}$ (p < 0.05)and experimental year $(\mathrm{p}<0.05)$ under LL conditions (2010/ 2012 comparison) but not under HL conditions (2011/2012 comparison; Fig. 4-5b \& 4-5d).

\subsubsection{Lipid, symbiont and pigment density}

\section{Results}

Corals reared under HL conditions exhibited significantly higher $(\mathrm{p}<0.01$; Fig. 44a) age-normalized total tissue lipid densities and significantly less ( $p<0.05$; Fig. 4-4c) chlorophyll $a$ than corals under LL conditions, regardless of $\mathrm{CO}_{2}$ level; We did not detect a significant effect due to light on age-normalized symbiont densities (Fig. 4-4b), nor were there significant effects due to $\mathrm{CO}_{2}$ or the interaction between light and $\mathrm{CO}_{2}$ on lipid, symbiont or pigment density (Fig. 4-4).

\section{Inter-year Comparison Results}

We did not detect significant effects due to $\mathrm{CO}_{2}$ or experimental year on age and sizenormalized total lipid content, symbiont density or chlorophyll $a$ content under LL (2010/ 2012 comparison) or HL (2011/2012 comparison) conditions (Figs. 4-6, 4-7, 4-8).

\subsection{Discussion}

In this study, we assessed the calcification, stored energetic reserves and the capacity to acquire nutrition via symbiont photosynthesis of recently settled $F$. fragum corals, which we 
subjected to various levels of $\mathrm{CO}_{2}$ and nutritional enhancement via heterotrophic feeding and light. These results, in comparison with those reported in studies such as Langdon \& Atkinson (2005), Holcomb et al. (2010), and Drenkard et al. (2013) help us better understand the mechanism(s) by which nutrition may impact coral calcification response to OA:

Comparable to the septa diameter data reported by Drenkard et al. (2013), heterotrophic feeding appears to be the dominant driver of corallite size among 2011 corals, with no significant effect due to $\mathrm{CO}_{2}$ in either 2011 or 2012 experiments (Fig. 4-3). Therefore, we similarly surmise that OA may have little impact on coral tissue extent, which we assume drives lateral corallite size (i.e., the larger the area covered by calcifying tissue, the larger the diameter of the accreted corallite; Davies 1984. However, unfed HL corals in the 2012 experiment were not significantly larger than LL corals, indicating that nutritional enhancement via light differs metabolically from heterotrophic feeding. This conclusion is consistent with Davies (1984) hypothesis that, although symbiont photosynthesis may provide the coral with considerable metabolic fuel, this carbon-rich "junk food" (Falkowski et al. 1984) may not provide sufficient structural materials (i.e., fixed nitrogen) for significantly increasing coral biomass.

With regards to total skeletal weight, Drenkard et al. (2013) propose that fed corals produce more $\mathrm{CaCO}_{3}$ due to their larger biomass and larger area over which $\mathrm{CaCO}_{3}$ is accreted. Despite being normalized for lateral size, 2011 fed corals are still significantly heavier than unfed corals, which may indicate a feeding effect on the actual calcification mechanism. However, given the somewhat consistent offset between fed and unfed corals (Fig. 4-2a), it may reflect the discrepancy in vertical size between feeding groups. Unlike fed corals in Drenkard et al. (2013), we were not able to detect a significant effect due to $\mathrm{CO}_{2}$ among corals in the 2011, HL experiment, which suggests that light availability may influence coral response to OA. However, we were also not able to detect a statistically significant effect due to light or $\mathrm{CO}_{2}$ in the 2012 LL skeletal weight data (Fig. 4-3b), which contradicts the results in Drenkard et al. (2013) and may be due to the shorter experimental duration (i.e., only 2 weeks in 2012 instead of 3 weeks in 2010).

That corals reared under LL conditions (2010/ 2012 comparison, Fig. 4-5a \& 4-5c) but not under HL conditions (2011/2012 comparison, Fig 4-5b \& 4-5d) exhibit a significant 
effect due to $\mathrm{CO}_{2}$ supports the hypothesis that light can reduce calcification sensitivity to OA. This is similar to the findings presented by Suggett et al. (2013) and is consistent with results from Holcomb et al. (2010) and Langdon \& Atkinson (2005) wherein nutritional enhancement via inorganic nutrients reduces the difference in calcification rate between corals under ambient and high $\mathrm{CO}_{2}$ conditions. However, as in the nutrient enrichment studies, the reduction in $\mathrm{CO}_{2}$ sensitivity among 2011 relative to 2010 corals (Fig. 4-5a vs. 4-5b) appears to be due more to a decrease in coral calcification under ambient $\mathrm{CO}_{2}$ rather than an increase under high $\mathrm{CO}_{2}$ relative to their LL counterparts. These results may be explained largely by the role of light and its ability to stimulate symbiont photosynthesis: Marubini \& Davies (1996) hypothesize that observed reductions in calcification under ambient $\mathrm{CO}_{2}$ and elevated nutrients may be due to endogenous DIC limitation, wherein nutrientenhanced photosynthesis consumes intercellular/respiratory $\mathrm{CO}_{2}$ reducing the amount of carbon available for calcification. OA would thus mitigate this DIC limitation because there would be sufficient carbon available to support both processes (Holcomb et al. 2010). Also, Falkowski et al. (1993) propose that the addition of inorganic nitrogen disrupts the nutrient limitation imposed by the coral host on its algal symbionts, effectively allowing the zooxanthellae to retain their photosynthate for growth and division and reducing the amount transferred to the host coral that it could metabolize to maintain proton pumping (Muscatine et al. 1989).

Smith \& Muscatine (1986) and Muscatine et al. (1989) demonstrated that ammonium additions significantly increase symbiont densities in Stylophora pistillata both in situ and in experimental settings, with an increase in the fixed nitrogen content of symbiont tissue. Additionally, studies assessing the effect due to depth/ light availability generally show coral photoadaptation with higher chlorophyll concentrations (Falkowski \& Dubinsky 1981, Porter et al. 1984) under low light conditions. Our study is consistent with these latter findings: although we did not observe a significant difference in symbiont densities for different light conditions during the 2012 light experiment (Fig. 4-4b \& Fig. 4-7), chlorophyll $a$ concentrations were considerably higher under low light conditions (Fig. 4-4c \& Fig. 4-8). However, it is difficult to say whether this result, and that LL corals from 2010 appear to exhibit higher symbiont densities than HL 2011 corals (Fig. 4-7a vs. 4-7b), are due to a light-compensation response or to greater DIN availability: In both HL experiments 
(2011/2012), there was an apparent drawdown of DIN: nitrate and nitrite concentrations were reduced by an order of magnitude relative to the original fill water conditions, and the lack of ammonium buildup observed in LL tanks did not occur ( 4.2). This was likely due to considerable algal growth observed in HL tanks, whereas nutritional competition and ammonium recycling by external algal species was probably lower under LL conditions.

Regardless, even with lower photosynthetic capacity (i.e., chlorophyll $a$ densities), HL corals still exhibited significantly greater total tissue lipid content (Fig. 4-4a \& Fig. 4-6), demonstrating the contrast in holobiont response to different forms of nutritional enhancement. This is likely due to the nature of the nutritional enhancement: elevating light does not increase the availability of photosynthesis substrate (i.e., $\mathrm{CO}_{2}$ ) or symbiont structural materials (i.e., DIN), but, until saturating light levels are reached, it does provide additional energy to drive the photosynthesis process. Under continued host-imposed nutrient limitation, symbionts would be unable to utilize and retain this excess, carbon-rich photosynthate for growth and division, thus increasing the transfer to the coral host. Our tissue lipid results (Fig 4-6) are consistent with this hypothesis, suggesting that HL corals are receiving additional carbohydrate resources. However, the fact that these corals are not significantly (2012 comparison) or only marginally (2011/2012 inter-year comparison; Fig. 4-1) larger than corals raised under low light conditions, suggests that this lipid material is not contributing to expanding tissue extent, but rather is being stored by the coral as a metabolic fuel reserve. This is consistent with several previous studies which have found elevated concentration of storage lipid content in corals maintained under elevated light conditions (e.g., Stimson 1987, Oku et al. 2003). Further analysis of the lipid composition, specifically quantify structural vs. storage lipid content, would be instrumental in furthering this hypothesis.

Interestingly, though, we do not observe a reduction in lipid reserves under elevated $\mathrm{CO}_{2}$ conditions (Fig. 4-6) as we might expect if the corals were actively investing metabolic energy to offset OA-driven impacts on calcification (e.g., Ries 2011). Unfed corals, raised under LL conditions may not be able to invest energy in an OA-compensation response because these corals may already posses the minimal tissue lipid content necessary to survive, leaving insufficient excess to spare for countering $\mathrm{CO}_{2}$-induced reductions in calcification via proton pumping or other active calcification accelerants. However, it is not clear whether 
HL corals expend energetic resources to reduced OA sensitivity under high light, as there is no apparent consumption of lipid reserves under either $\mathrm{CO}_{2}$ condition (Fig. 4-4a \& 4-6). It is possible that OA-sensitivity reduction is due instead to $\mathrm{CO}_{2}$ removal by the symbionts and not increased proton removal by the coral: The high lipid stores (Fig. 4-4 b \& 4-4d) suggest that a considerable amount of carbon is being fixed by photosynthesis and with that, DIC limitation may be reducing calcification under ambient $\mathrm{CO}_{2}$ conditions (Marubini \& Davies 1996).

The importance of coral energetic reserves has been emphasized in the literature: corals with higher lipid content and that are metabolically flexible generally have lower mortality risk and are better able to survive stress events such as bleaching (e.g., Anthony et al. 2007, Rodrigues \& Grottoli 2007, Anthony et al. 2009). However, pervious studies have also observed that fed corals do not appear to utilize their stored energetic reserves to offset the impacts of $\mathrm{CO}_{2}$ on calcification (Drenkard et al. 2013, Schoepf et al. 2013), suggetsing that maintaining calcification rates may not be a metabolic priority for these scleractinian coral species.

\subsection{Conclusions}

To the extent that these findings can be extrapolated to larger scale reef ecosystems, our results suggest that coral organisms in regions with higher levels of inorganic nutrients and/or consistent and sufficient light availability will be less adversely affected by OA than corals in regions that are highly oligotrophic and/or prone to extensive cloud cover. However, the mechanism by which this resilience occurs is not clear as the corals do not appear to actively invest metabolic energy reserves in maintaining calcification rates. Furthermore, reductions in sea surface nutrient availability and productivity, projected as a result of $\mathrm{CO}_{2}$-induced SST rise and increased water column stratification (e.g. Behrenfeld et al. 2006, Steinacher et al. 2010, Stock et al. in press), may compound the detrimental impacts of elevated $\mathrm{CO}_{2}$ conditions, thus rendering affected coral systems more vulnerable to OA. 


\subsection{Acknowledgements}

The authors are grateful to Thomas DeCarlo (MIT/WHOI), Claire Ghallager, Kathrine Rose, Ms. Kascia White (BIOS) for assistance with fieldwork and experiment maintenance. This project was funded by NSF OCE-1041106 and NSF OCE-1041052 along with support from the MIT/WHOI Bermuda Biological Station for Research Fund. 


\subsection{References}

Anthony KRN, Connolly SR, Hoegh-Guldberg O (2007) Bleaching, energetics, and coral mortality risk: Effects of temperature, light, and sediment regime. Limnology and Oceanography 52

Anthony KRN, Hoogenboom MO, Maynard JA, Grottoli AG, Middlebrook R (2009) Energetics approach to predicting mortality risk from environmental stress: a case study of coral bleaching. Functional Ecology 23: 539-550

Atkinson M, Carlson B, Crow G (1995) Coral growth in high-nutrient, low-pH seawater: a case study of corals cultured at the Waikiki Aquarium, Honolulu, Hawaii. Coral Reefs 14: $215-223$

Atkinson MJ, Cuet P (2008) Possible effects of ocean acidification on coral reef biogeochemistry: topics for research. Marine Ecology Progress Series 373: 249-256

Behrenfeld MJ, O/'Malley RT, Siegel DA, McClain CR, Sarmiento JL, Feldman GC, Milligan AJ, Falkowski PG, Letelier RM, Boss ES (2006) Climate-driven trends in contemporary ocean productivity. Nature 444: $752-755$

Cantin NE, Negri AP, Willis BL (2007) Photoinhibition from chronic herbicide exposure reduces reproductive output of reef-building corals. Marine Ecology Progress Series 344: $81-93$

Chalker BE, Taylor DL (1975) Light-Enhanced Calcification, and the Role of Oxidative Phosphorylation in Calcification of the Coral Acropora cervicornis. Proceedings of the Royal Society of London Series B Biological Sciences 190: 323-331

Chan NCS, Connolly SR (2013) Sensitivity of coral calcification to ocean acidification: a meta-analysis. Global Change Biology 19: 282-290

Cohen A, Holcomb M (2009) Why corals care about ocean acidification: Uncovering the mechanism. Oceanography 22: 118-127

Cohen AL, McConnaughey TA (2003) Geochemical Perspectives on Coral Mineralization. Reviews in Mineralogy and Geochemistry 54: 151-187

Davies PS (1984) The role of zooxanthellae in the nutritional energy requirements of Pocillopora eydouxi. Coral Reefs 2: 181-186

Doney SC, Fabry VJ, Feely RA, Kleypas JA (2009) Ocean Acidification: The Other $\mathrm{CO}_{2}$ Problem. Annual Review of Marine Science 1: 169-192, pMID: 21141034

Drenkard E, Cohen A, McCorkle D, de Putron S, Starczak V, Zicht A (2013) Calcification by juvenile corals under heterotrophy and elevated $\mathrm{CO}_{2}$. Coral Reefs 32: 727-735

Edmunds J Peter (2011) Zooplanktivory ameliorates the effects of ocean acidification on the reef coral Porites spp. Limnology and Oceanography 56: 2402-2410 
Fabricius KE, Langdon C, Uthicke S, Humphrey C, Noonan S, De/'ath G, Okazaki R, Muehllehner N, Glas MS, Lough JM (2011) Losers and winners in coral reefs acclimatized to elevated carbon dioxide concentrations. Nature Climate Change 1: 165-169

Fabry VJ, Seibel BA, Feely RA, Orr JC (2008) Impacts of ocean acidification on marine fauna and ecosystem processes. ICES Journal of Marine Science: Journal du Conseil 65: $414-432$

Falkowski PG, Dubinsky Z (1981) Light-shade adaptation of Stylophora pistillata, a hermatypic coral from the Gulf of Eilat. Nature 289: 172-174

Falkowski PG, Dubinsky Z, Muscatine L, Porter JW (1984) Light and the Bioenergetics of a Symbiotic Coral. BioScience 34: 705-709

Falkowski PG, Dubinsky Z, Muscatine L, McCloskey L (1993) Population Control in Symbiotic Corals: Ammonium ions and organic materials maintain the density of zooxanthellae. BioScience 43: 606-611

Ferrier-Pagès C, Hoogenboom M, Houlbrèque F (2011) The Role of Plankton in Coral Trophodynamics. In: Dubinsky Z, Stambler N (eds.) Coral Reefs: An Ecosystem in Transition, 215-229, Springer Netherlands

Folch J, Lees M, Sloane Stanley GH (1957) A simple method for the isolation and purification of total lipides from animal tissues. Journal of Biological Chemistry 226: 497-509

Gattuso JP, Frankignoulle M, Bourge I, Romaine S, Buddemeier R (1998) Effect of calcium carbonate saturation of seawater on coral calcification. Global and Planetary Change 18: $37-46$

Gattuso JP, Allemand D, Frankignoulle M (1999) Photosynthesis and Calcification at Cellular, Organismal and Community Levels in Coral Reefs: A Review on Interactions and Control by Carbonate Chemistry. American Zoologist 39: 160-183

Goodbody-Gringley G, de Putron SJ (2009) Planulation patterns of the brooding coral Favia fragum (Esper) in Bermuda. Coral Reefs 28: 959-963

Hoegh-Guldberg O, Mumby PJ, Hooten AJ, Steneck RS, Greenfield P, Gomez E, Harvell CD, Sale PF, Edwards AJ, Caldeira K, Knowlton N, Eakin CM, Iglesias-Prieto R, Muthiga N, Bradbury RH, Dubi A, Hatziolos ME (2007) Coral Reefs Under Rapid Climate Change and Ocean Acidification. Science 318: 1737-1742

Holcomb M, McCorkle DC, Cohen AL (2010) Long-term effects of nutrient and $\mathrm{CO}_{2}$ enrichment on the temperate coral Astrangia poculata (Ellis and Solander, 1786). Journal of Experimental Marine Biology and Ecology 386: 27-33

Holcomb M, Cohen AL, McCorkle DC (2012) An investigation of the calcification response of the scleractinian coral Astrangia poculata to elevated $\mathrm{pCO}_{2}$ and the effects of nutrients, zooxanthellae and gender. Biogeosciences 9: 29-39

Langdon C, Atkinson MJ (2005) Effect of elevated $\mathrm{pCO}_{2}$ on photosynthesis and calcification of corals and interactions with seasonal change in temperature/irradiance and nutrient enrichment. Journal of Geophysical Research: Oceans 110: C09S07 
Langdon C, Takahashi T, Sweeney C, Chipman D, Goddard J, Marubini F, Aceves H, Barnett H, Atkinson MJ (2000) Effect of calcium carbonate saturation state on the calcification rate of an experimental coral reef. Global Biogeochemical Cycles 14: 639-654

Marubini F, Davies P (1996) Nitrate increases zooxanthellae population density and reduces skeletogenesis in corals. Marine Biology 127: 319-328

McConnaughey T, Whelan J (1997) Calcification generates protons for nutrient and bicarbonate uptake. Earth-Science Reviews 42: 95-117

Muscatine L, Falkowski PG, Dubinsky Z, Cook PA, McCloskey LR (1989) The Effect of External Nutrient Resources on the Population Dynamics of Zooxanthellae in a Reef Coral. Proceedings of the Royal Society of London B Biological Sciences 236: 311-324

Oku H, Yamashiro H, Onaga K, Sakai K, Iwasaki H (2003) Seasonal changes in the content and composition of lipids in the coral Goniastrea aspera. Coral Reefs 22: 83-85

Pandolfi JM, Connolly SR, Marshall DJ, Cohen AL (2011) Projecting Coral Reef Futures Under Global Warming and Ocean Acidification. Science 333: 418-422

Porter JW, Muscatine L, Dubinsky Z, Falkowski PG (1984) Primary Production and Photoadaptation in Light- and Shade-Adapted Colonies of the Symbiotic Coral, Stylophora pistillata. Proceedings of the Royal Society of London Series B Biological Sciences 222: $161-180$

Ries JB (2011) A physicochemical framework for interpreting the biological calcification response to $\mathrm{CO}_{2}$-induced ocean acidification. Geochimica et Cosmochimica Acta 75: 4053 $-4064$

Ries JB, Cohen AL, McCorkle DC (2009) Marine calcifiers exhibit mixed responses to CO2-induced ocean acidification. Geology 37: 1131-1134

Rodolfo-Metalpa R, Houlbreque F, Tambutte E, Boisson F, Baggini C, Patti FP, Jeffree R, Fine M, Foggo A, Gattuso JP, Hall-Spencer JM (2011) Coral and mollusc resistance to ocean acidification adversely affected by warming. Nature Climate Change 1: 308-312

Rodrigues LJ, Grottoli A (2007) Energy reserves and metabolism as indicators of coral recovery from bleaching. Limnology and Oceanography 52: 1874-1882

Schoepf V, Grottoli A, Warner ME, Cai WJ, Melman TF, Hoadley KD, Pettay DT, Hu X, Li Q, Xu H, Wang Y, Matsui Y, Baumann JH (2013) Coral Energy Reserves and Calcification in a High-CO2 World at Two Temperatures. PLoS ONE 9: e108082

Shamberger K, Feely R, Sabine C, Atkinson M, DeCarlo E, Mackenzie F, Drupp P, Butterfield D (2011) Calcification and organic production on a Hawaiian coral reef. Marine Chemistry 127: 64-75

Shamberger KEF, Cohen AL, Golbuu Y, McCorkle DC, Lentz SJ, Barkley HC (2014) Diverse coral communities in naturally acidified waters of a Western Pacific reef. Geophysical Research Letters 41: 499-504 
Silverman J, Lazar B, Erez J (2007) Community metabolism of a coral reef exposed to naturally varying dissolved inorganic nutrient loads. Biogeochemistry 84: 67-82

Smith G, Muscatine LL (1986) Carbon budget and regulation of the population-density of symbiotic algae. Endocytobiosis and Cell Research 3: 213-238

Steinacher M, Joos F, Fröolicher TL, Bopp L, Cadule P, Cocco V, Doney SC, Gehlen M, Lindsay K, Moore JK, Schneider B, Segschneider J (2010) Projected 21st century decrease in marine productivity: a multi-model analysis. Biogeosciences 7: 979-1005

Stimson J (1987) Location, quantity and rate of change in quantity of lipids in tissues of Hawaiian hermatypie corals. Bulletin of Marine Science 41: 889-904

Suggett D, Dong L, Lawson T, Lawrenz E, Torres L, Smith D (2013) Light availability determines susceptibility of reef building corals to ocean acidification. Coral Reefs 32: $327-337$

Wright SW, Jeffrey SW, Mantoura RFC, Llewellyn CA, Bjornland T, Repeta D, Welschmeyer N (1991) Improved HPLC method for the analysis of chlorophylls and carotenoids from marine phytoplankton. Marine Ecology Progress Series 77: 183-196

Zoccola D, Tambutté E, Kulhanek E, Puverel S, Scimeca JC, Allemand D, Tambutté S (2004) Molecular cloning and localization of a $\{$ PMCA $\}$ P-type calcium \{ATPase from the coral Stylophora pistillata. Biochimica et Biophysica Acta (BBA) - Biomembranes 1663: $117-126$ 


\begin{tabular}{|c|c|c|c|c|c|c|c|c|c|}
\hline $\begin{array}{c}\text { Year \& Light } \\
\text { Condition }\end{array}$ & $\begin{array}{c}\text { Feeding } \\
\text { Treatment }\end{array}$ & $\begin{array}{l}\mathrm{CO}_{2} \text { Treatment } \\
\left(\mathrm{ppm} \mathrm{CO}_{2} \pm \mathrm{SD}\right)\end{array}$ & $\begin{array}{l}\text { Temperature } \\
\left({ }^{\circ} \mathrm{C} \pm \mathrm{SD}\right)\end{array}$ & $\begin{array}{c}\text { Salinity } \\
(\mathrm{psu} \pm \mathrm{SD})\end{array}$ & $\begin{array}{c}\text { Alkalinity } \\
\left(\mu \mathrm{eq} \mathrm{kg}^{-1} \pm\right. \\
\mathrm{SD})\end{array}$ & $\begin{array}{c}\mathrm{DIC} \\
\left(\mu \mathrm{mol} \mathrm{kg}^{-1}\right. \\
\pm \mathrm{SD})\end{array}$ & $\begin{array}{c}{\left[\mathrm{HCO}_{3}^{-}\right]} \\
\left(\mu \mathrm{mol} \mathrm{kg}{ }^{-1}\right. \\
\pm \mathrm{SD})\end{array}$ & $\begin{array}{c}{\left[\mathrm{CO}_{3}{ }^{2-}\right]} \\
\left(\mu \mathrm{mol} \mathrm{kg}{ }^{-1}\right. \\
\pm \mathrm{SD}) \\
\end{array}$ & $\begin{aligned} & \Omega a r \\
&( \pm \mathrm{SD})\end{aligned}$ \\
\hline \multirow{8}{*}{$\begin{array}{c}2011 \\
\text { High Light }\end{array}$} & \multirow{4}{*}{ Fed } & $420 \pm 10$ & $27.4 \pm 0.6$ & $36.5 \pm 0.9$ & $2,154 \pm 110$ & $1,853 \pm 70$ & $1,635 \pm 68$ & $207 \pm 46$ & $3.28 \pm 0.71$ \\
\hline & & $1,060 \pm 10$ & $27.3 \pm 0.5$ & $36.6 \pm 1.4$ & $2,200 \pm 82$ & $2,054 \pm 42$ & $1,907 \pm 44$ & $121 \pm 33$ & $1.92 \pm 0.51$ \\
\hline & & $1,720 \pm 90$ & $27.6 \pm 0.4$ & $36.1 \pm 0.6$ & $2,251 \pm 67$ & $2,148 \pm 72$ & $2,016 \pm 74$ & $95 \pm 20$ & $1.52 \pm 0.32$ \\
\hline & & $2,660 \pm 10$ & $27.2 \pm 0.4$ & $36.3 \pm 0.9$ & $2,406 \pm 45$ & $2,350 \pm 53$ & $2,220 \pm 52$ & $76 \pm 12$ & $1.21 \pm 0.19$ \\
\hline & \multirow{4}{*}{ Unfed } & $420 \pm 10$ & $27.2 \pm 0.4$ & $36.2 \pm 0.9$ & $2,160 \pm 109$ & $1,852 \pm 83$ & $1,629 \pm 74$ & $212 \pm 31$ & $3.38 \pm 0.48$ \\
\hline & & $1,060 \pm 10$ & $27.5 \pm 0.5$ & $36.3 \pm 1.0$ & $2,162 \pm 86$ & $2,003 \pm 64$ & $1,857 \pm 53$ & $123 \pm 20$ & $1.95 \pm 0.31$ \\
\hline & & $1,720 \pm 90$ & $27.3 \pm 0.6$ & $36.8 \pm 1.4$ & $2,315 \pm 123$ & $2,222 \pm 72$ & $2,084 \pm 62$ & $94 \pm 31$ & $1.48 \pm 0.47$ \\
\hline & & $2,660 \pm 10$ & $27.5 \pm 0.5$ & $36.4 \pm 1.0$ & $2,370 \pm 69$ & $2,314 \pm 69$ & $2,186 \pm 66$ & $75 \pm 13$ & $1.20 \pm 0.21$ \\
\hline 2012 & \multirow{2}{*}{ Unfed } & $430 \pm 20$ & $27.6 \pm 0.3$ & $36.8 \pm 0.5$ & $2,352 \pm 33$ & $2,018 \pm 28$ & $1,772 \pm 40$ & $236 \pm 11$ & $3.72 \pm 0.19$ \\
\hline Low Light & & $1,920 \pm 20$ & $27.7 \pm 0.3$ & $36.8 \pm 0.5$ & $2,392 \pm 69$ & $2,281 \pm 63$ & $2,141 \pm 58$ & $103 \pm 11$ & $1.62 \pm 0.17$ \\
\hline 2012 & \multirow{2}{*}{ Unfed } & $430 \pm 20$ & $27.6 \pm 0.4$ & $36.6 \pm 0.2$ & $2,335 \pm 27$ & $2,003 \pm 17$ & $1,757 \pm 11$ & $234 \pm 8$ & $3.72 \pm 0.12$ \\
\hline High Light & & $1,920 \pm 20$ & $27.7 \pm 0.4$ & $36.7 \pm 0.4$ & $2,357 \pm 24$ & $2,254 \pm 24$ & $2,119 \pm 23$ & $97 \pm 8$ & $1.54 \pm 0.12$ \\
\hline
\end{tabular}

Table 4.1: Measured and calculated carbonate chemistry parameters. Average ( \pm SD) among replicate tanks of a given treatment. 


\begin{tabular}{|c|c|c|c|c|}
\hline Year & $\begin{array}{c}\mathrm{CO}_{2} \\
\text { Treatment }\end{array}$ & $\begin{array}{c}\text { Ammonium } \\
\left(\mu \mathrm{M} \mathrm{NH}{ }^{+} \pm \mathrm{SD}\right)\end{array}$ & $\begin{array}{c}\text { Phosphate } \\
\left(\mu \mathrm{M} \mathrm{PO}_{4}{ }^{3-} \pm \mathrm{SD}\right)\end{array}$ & $\begin{array}{c}\text { Nitrite \& Nitrate } \\
\left(\mu \mathrm{M} \mathrm{N0} 0_{2}+\mathrm{NO}_{3}^{-} \pm \mathrm{SD}\right)\end{array}$ \\
\hline 2010 & Fill Water & $0.94 \pm 0.53$ & $0.11 \pm 0.04$ & $0.46 \pm 0.23$ \\
\hline \multirow{2}{*}{ Low Light } & Ambient $\mathrm{CO}_{2}$ & $6.31 \pm 1.46$ & $0.15 \pm 0.10$ & $0.46 \pm 0.40$ \\
\hline & $\mathrm{High} \mathrm{CO}_{2}$ & $3.26 \pm 2.34$ & $0.10 \pm 0.03$ & $0.29 \pm 0.28$ \\
\hline 2011 & Fill Water & $0.56 \pm 0.35$ & $0.09 \pm 0.05$ & $0.85 \pm 0.20$ \\
\hline \multirow{2}{*}{ High Light } & Ambient $\mathrm{CO}_{2}$ & $0.44 \pm 0.13$ & $0.09 \pm 0.02$ & $0.08 \pm 0.03$ \\
\hline & High $\mathrm{CO}_{2}$ & $0.33 \pm 0.18$ & $0.07 \pm 0.01$ & $0.06 \pm 0.01$ \\
\hline 2012 & Fill Water & $<0.05$ & $<0.05$ & $0.71 \pm 0.33$ \\
\hline \multirow{2}{*}{ Low Light } & Ambient $\mathrm{CO}_{2}$ & $4.14 \pm 0.38$ & $<0.05$ & $0.45 \pm 0.16$ \\
\hline & $\mathrm{High} \mathrm{CO}_{2}$ & $4.81 \pm 0.32$ & $<0.05$ & $0.44 \pm 0.15$ \\
\hline \multirow{2}{*}{ High Light } & Ambient $\mathrm{CO}_{2}$ & $0.42 \pm 0.54$ & $<0.05$ & $<0.05$ \\
\hline & High $\mathrm{CO}_{2}$ & $0.09 \pm 0.09$ & $<0.05$ & $<0.05$ \\
\hline
\end{tabular}

Table 4.2: Nutrient measurements. Average ( \pm SD) seawater chemistry of replicate aquaria for a given experimental conditions (treatment). Tanks sampled after one week. These values are somewhat approximate; where values were indicated as "ower than a detection limit" the value was replaced with the next $0.005 \mu \mathrm{M}$ lower for calculation purposes (e.g. ¡0.05 uM became $0.045 \mu \mathrm{M})$. 


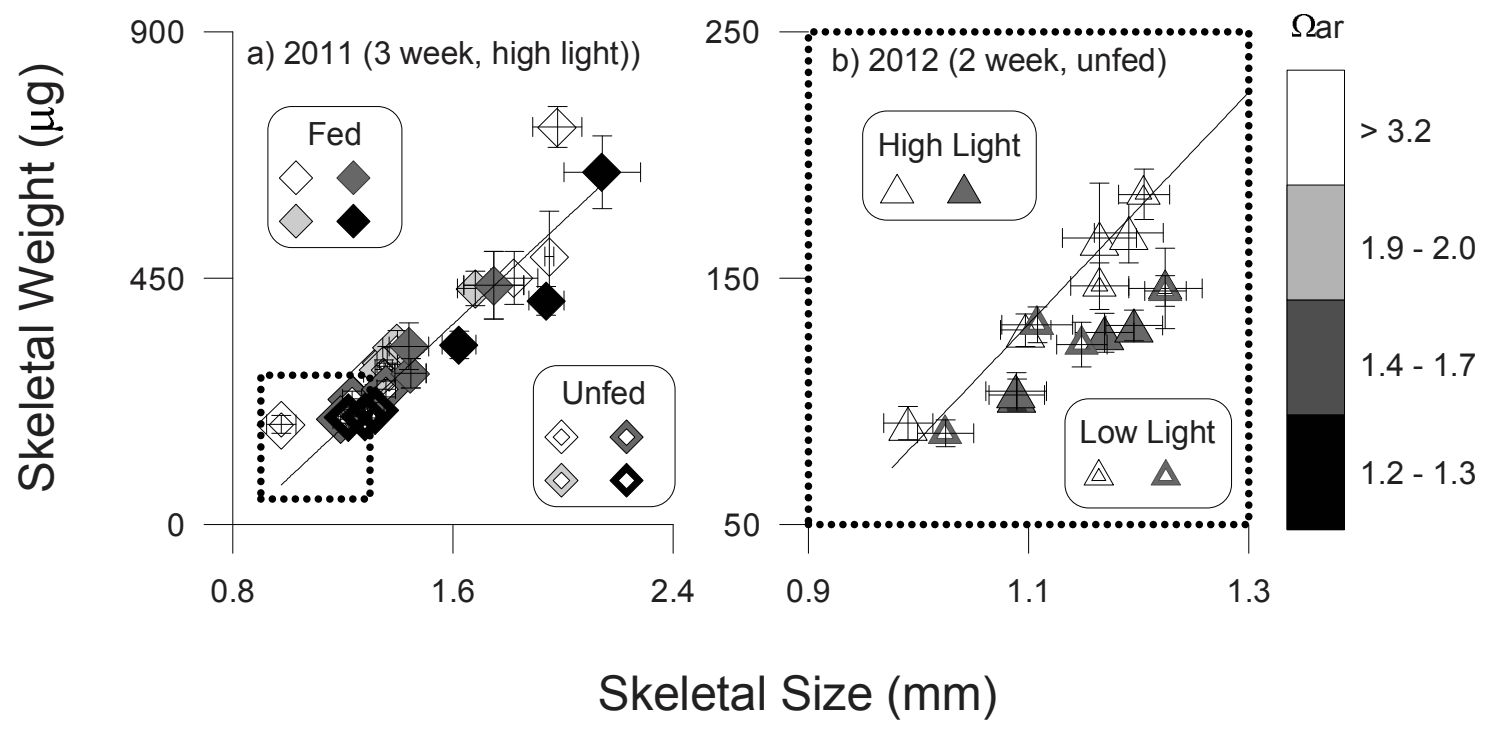

Figure 4-1: Juvenile coral skeletal weight vs. diameter (i.e., size) from a) 2011 and b) 2012. The correlation $\left(\mathrm{R}^{2}=0.89\right)$ between skeletal size and weight is illustrated by the plotted linear regression. Note: the regression was computed using data from both experiments but are separated by year to improve data readability, Each symbol represents the average weight and size for a given treatment tank. Filled symbols indicate elevated nutrition (i.e., fed or high light conditions), hollow symbols indicate limited nutrition (i.e., unfed or low light conditions) and symbol shading represents the saturation state range. Error bars indicate \pm 1 standard error. 


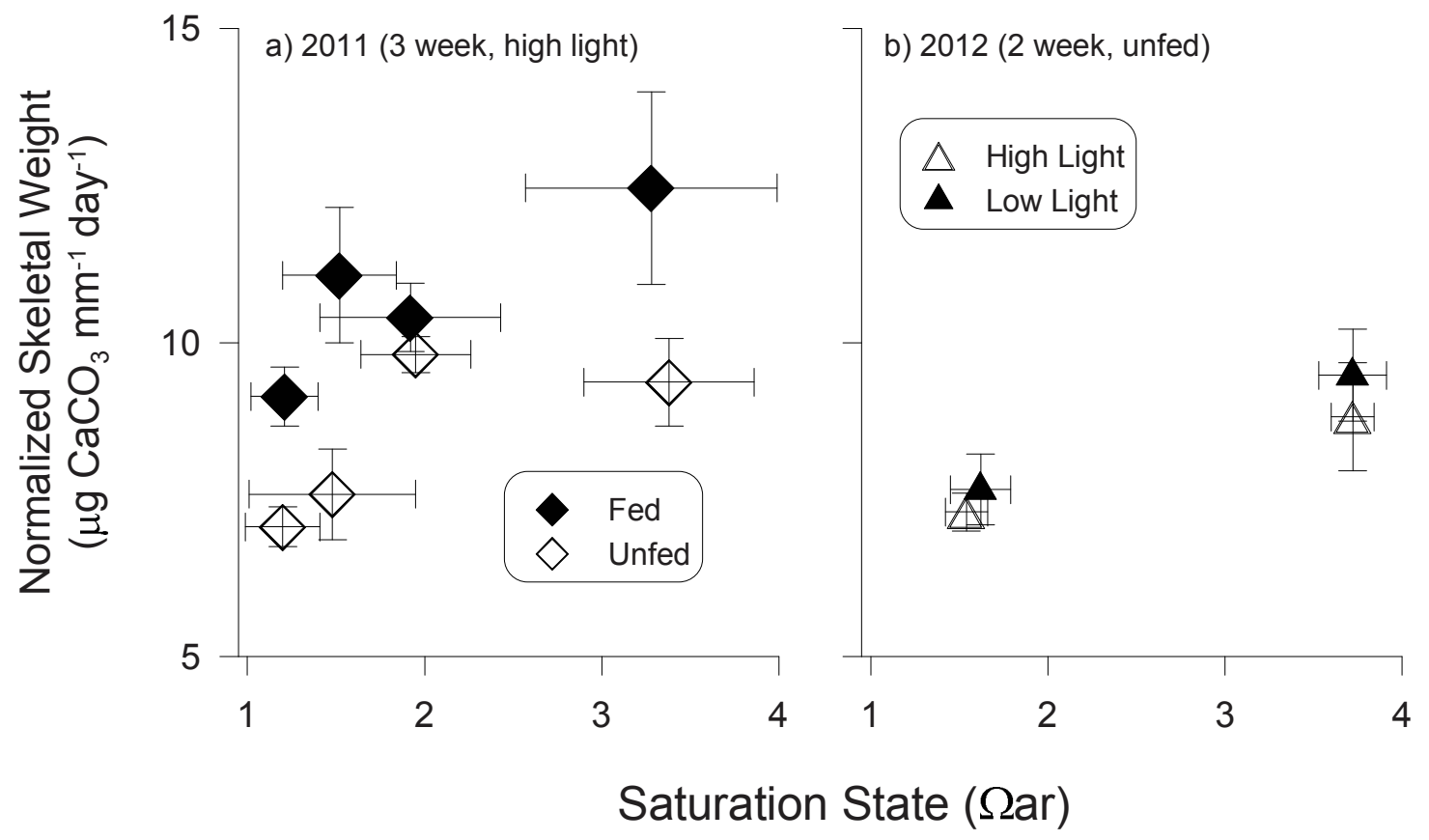

Figure 4-2: Juvenile coral age- and size-normalized skeletal weight from a) 2011 and b) 2012 experiments plotted against the average aragonite saturation state of their respective treatment conditions. Vertical error bars indicate \pm 1 standard error and horizontal error bars indicate \pm the average standard deviation among treatment tanks. 


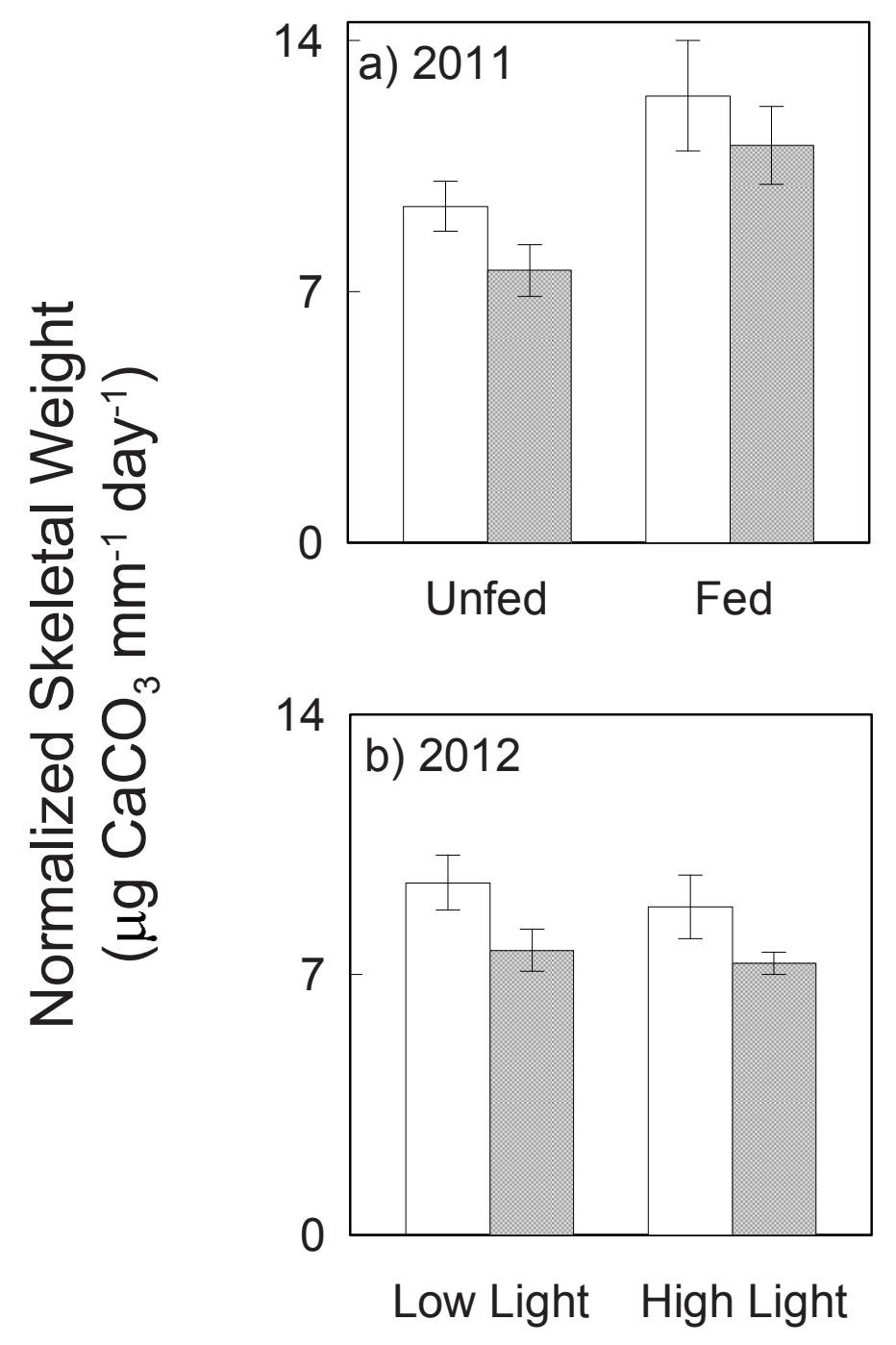

Figure 4-3: Juvenile coral age- and size-normalized skeletal weight from the a) 2011 and b) 2012 experiments. White (shaded) bars represent ambient (elevated) $\mathrm{CO}_{2}$ conditions; Error bars indicate \pm 1 standard error 

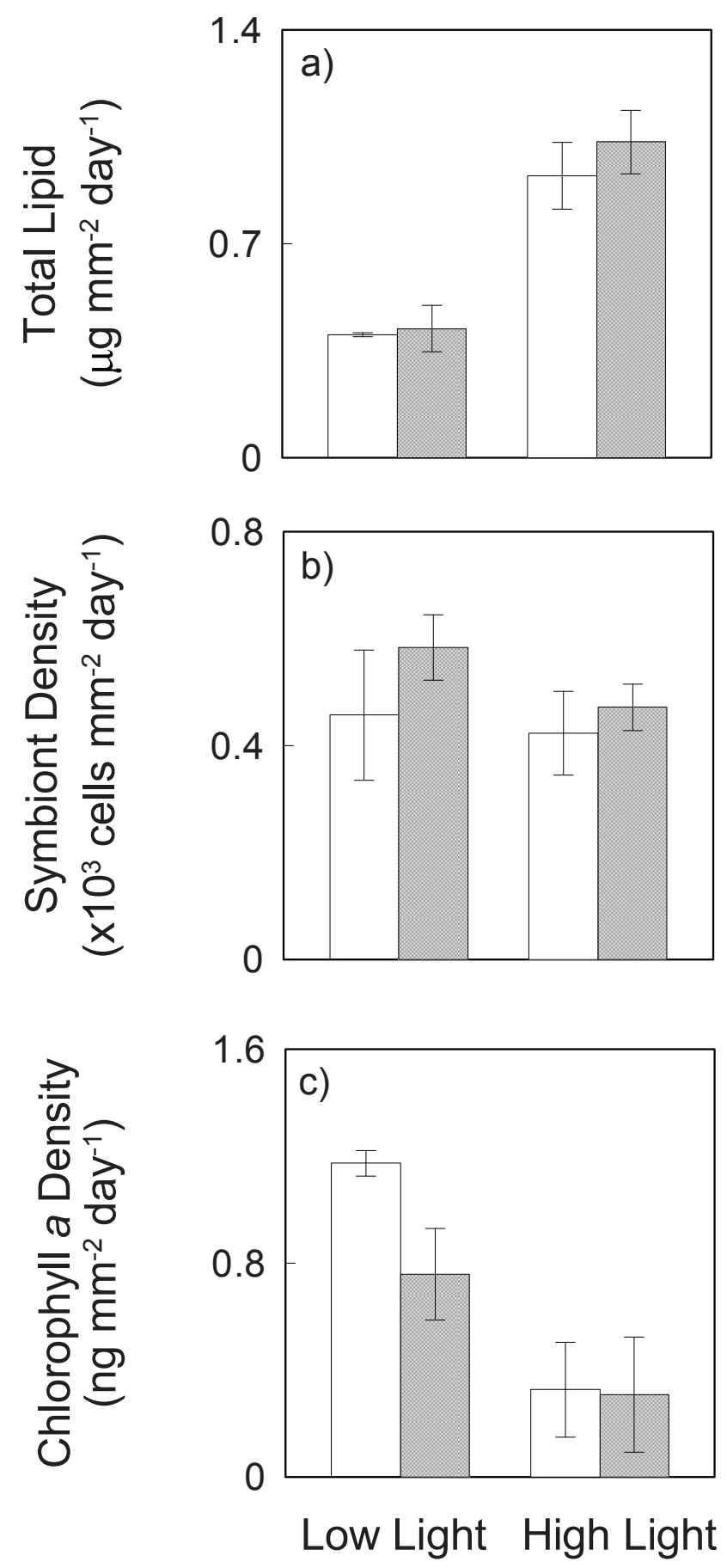

Figure 4-4: Age-and area- normalized a) total tissue lipid content, b) symbiont density, and c) chlorophyll $a$ density from the 2012, light and $\mathrm{CO}_{2}$ experiment. White (shaded) bars represent ambient (elevated) $\mathrm{CO}_{2}$ conditions; Error bars indicate \pm 1 standard error 


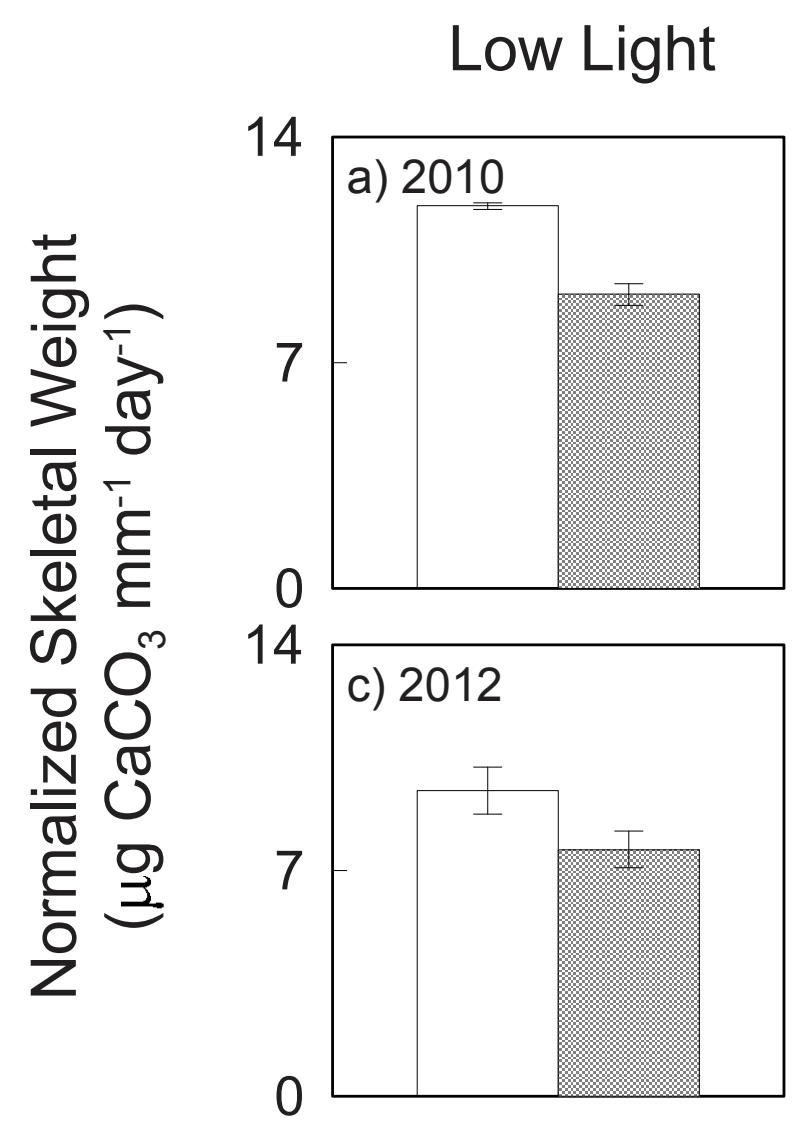

High Light
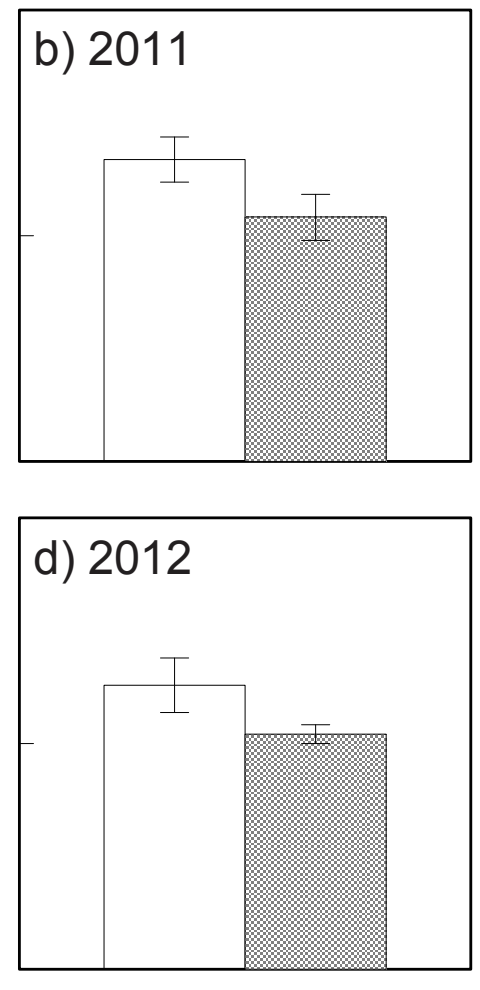

Figure 4-5: Juvenile coral age- and area-normalized skeletal weight from the a) 2010, b) 2011, c \& d) 2012 experiments. White (shaded) bars represent ambient (elevated) $\mathrm{CO}_{2}$ conditions; Error bars indicate \pm 1 standard error 


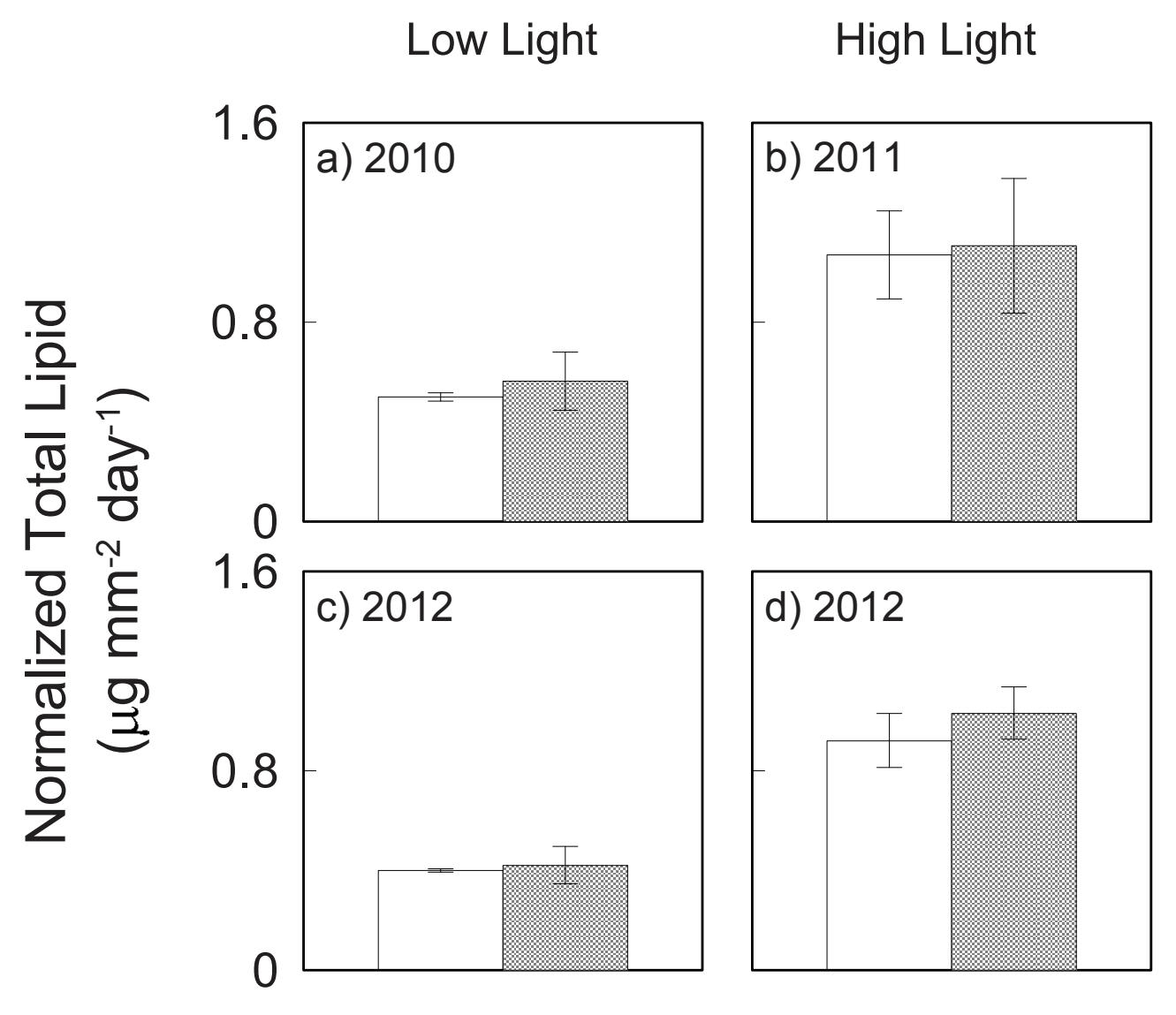

Figure 4-6: Juvenile coral age- and area-normalized total lipid content from the a) 2010, b) 2011, c \& d) 2012 experiments. White (shaded) bars represent ambient (elevated) $\mathrm{CO}_{2}$ conditions; Error bars indicate \pm 1 standard error 


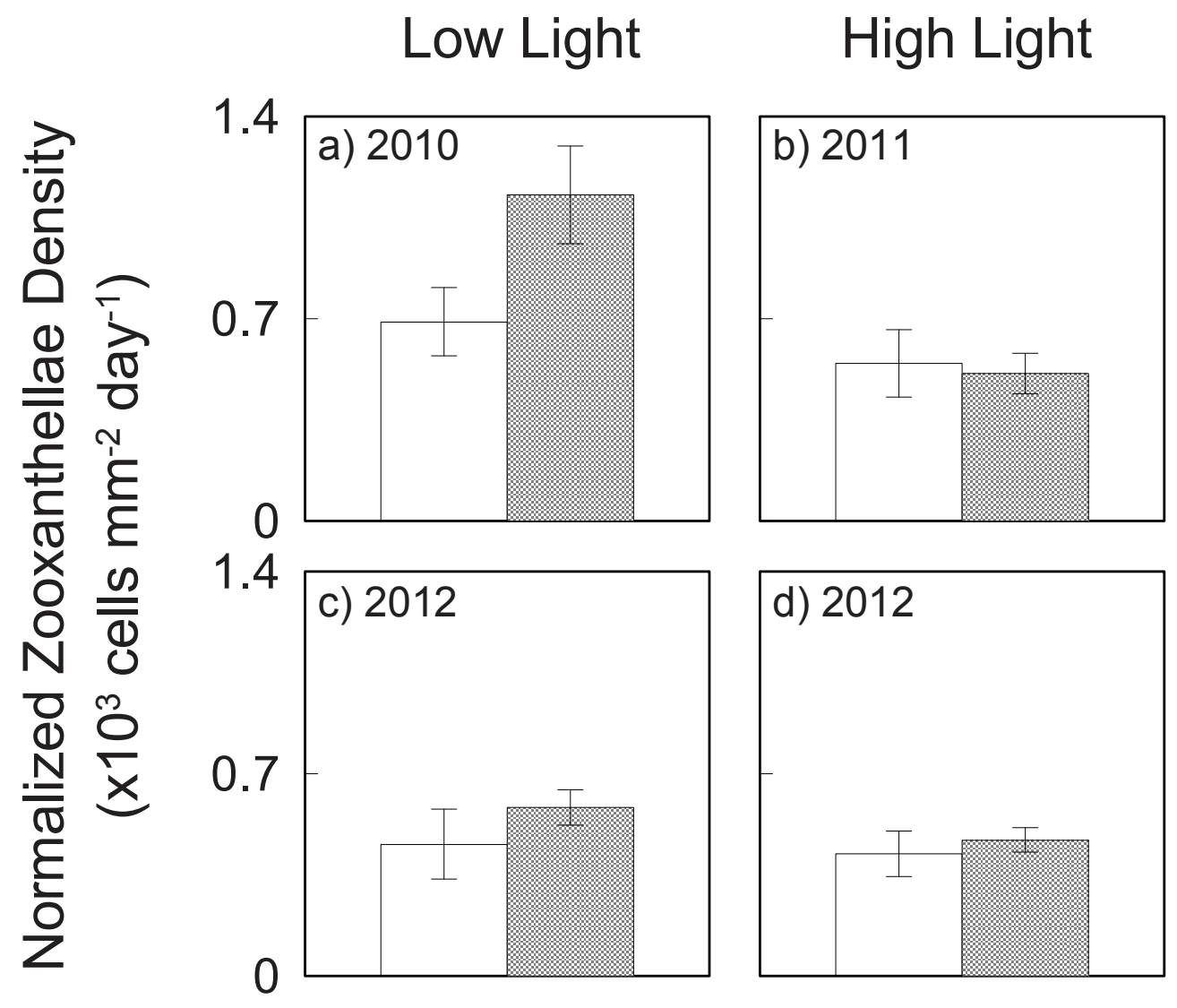

Figure 4-7: Juvenile coral age- and area-normalized symbiont densities from the a) 2010, b) 2011, c \& d) 2012 experiments. White (shaded) bars represent ambient (elevated) $\mathrm{CO}_{2}$ conditions; Error bars indicate \pm 1 standard error 
Low Light

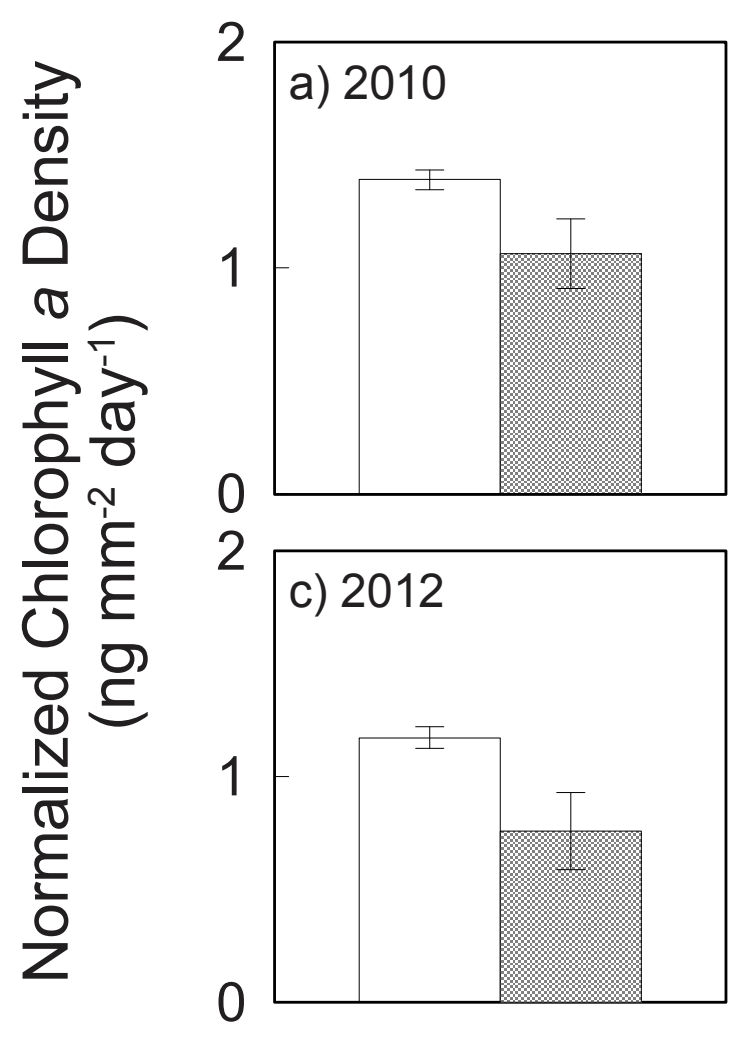

High Light

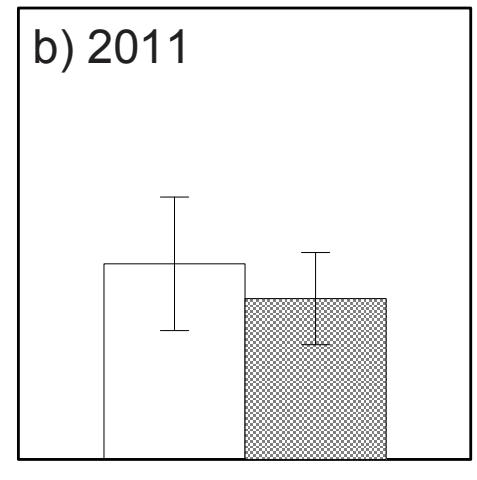

d) 2012

Figure 4-8: Juvenile coral age- and area-normalized chlorophyll $a$ concentrations from the a) 2010, b) 2011, c \& d) 2012 experiments. White (shaded) bars represent ambient (elevated) $\mathrm{CO}_{2}$ conditions; Error bars indicate \pm 1 standard error 


\section{Chapter 5}

\section{Conclusions}

If anthropogenic $\mathrm{CO}_{2}$ emissions continue unabated, it is likely that once pristine and diverse coral reef ecosystems will degrade beyond the point of recovery (Veron et al. 2009) Focusing conservation efforts on environmental refugia where oceanographic conditions naturally mitigate $\mathrm{CO}_{2}$-driven stressors may increase the probability of conservation success (West \& Salm 2003; Riegl \& Piller 2003). However, rising levels of atmospheric $\mathrm{CO}_{2}$ drive changes in multiple ocean properties (e.g., temperature, $\mathrm{pH}$ ) and these in turn drive other changes that also affect coral reef ecosystems (e.g., stratification and productivity). Understanding and predicting the nature, magnitude, and interaction of these changes for specific coral reef ecosystems and the potential range of responses of coral reef organisms is necessary for the development of appropriate and effective conservation strategies.

For coral reef islands in the central equatorial Pacific, my research has shown that: 1) the EUC has intensified over the last 140 years. This finding bolsters the hypothesis that future EUC intensification may strengthen upwelling around equatorial Pacific islands, thus reducing the impact of rising SST on these reefs (Karnauskas \& Cohen 2012); and 2) although corals on these reef systems will be exposed to elevated levels of $\mathrm{CO}_{2}$, which can be detrimental to skeletal growth, this response may be offset, at least partially, by the nutritional enhancement conferred by nutrient-rich EUC water. We observe two distinct patterns of OA-nutrition interactions: i) heterotrophic feeding results in larger corals that produce more calcium carbonate but remain sensitive to elevated $\mathrm{CO}_{2}$ levels and ii) elevated light levels does not affect corallite size but reduce coral calcification sensitivity to $\mathrm{CO}_{2}$.

Our assessment of the Simple Ocean Data Assimilation (SODA) reanalysis suggests that there is robust evidence of EUC intensification since the late 1800s (Chapter 2). This historical precedent lends indirect support to model projections of future EUC intensification (e.g., Luo et al. 2009, Sen Gupta et al. 2012, Karnauskas \& Cohen 2012). If the projected EUC intensification occurs, increased topographic upwelling of EUC waters on equatorial Pacific islands will reduce projected warming of the sea surface around these islands (Karnauskas \& Cohen 2012). The historical intensification signal is dominated by two dynamically distinct 
seasonal mechanisms, which we have characterized through decomposition and diagnosis of equatorial Pacific zonal momentum budget. The first mechanism entails strengthening of the pressure gradient force, which occurs due to strengthening of the trade winds and sea surface height gradient in the western Pacific during boreal spring. The second, which occurs in boreal summer, is characterized by a reduction in vertical shear stress caused by weakening of the eastern Pacific trade winds and surface current, resulting in local shoaling and acceleration of the EUC.

Interannual variability of EUC intensity, especially as it relates to the El Niño Southern Oscillation (ENSO), may limit the ability of equatorial Pacific islands to act as refugia. Although we demonstrate historical strengthening of the EUC throughout the annual cycle (Fig. 2-5e), the EUC will weaken during strong El Niño events (e.g., Firing et al. 1983), causing warming that could render equatorial Pacific islands vulnerable (e.g., D'Croz et al. 2001). However, to counter this concern, one study of the response of Gilbert Islands corals to thermal stress suggests that corals naturally exposed to higher amplitude thermal variability, as are the equatorial communities, are less susceptible to heat stress which may enable them to withstand temporary reductions in EUC intensity (Carilli et al. 2012).

The nutritional benefit to corals conferred by nutrients and productivity associated with EUC upwelling may further mitigate thermal stress from El Niño events. Energetic (e.g., lipid) reserves and biomass accumulated by corals prior to thermal stress events are likely crucial to their survival (e.g., Rodrigues \& Grottoli 2007, Anthony et al. 2007, Anthony et al. 2009, Thornhill et al. 2011). In Chapter 3, we demonstrate that fed corals have greater total lipid content and biomass. Also, massive Porites sp. from equatorial Pacific islands exhibit a longitudinal gradient in tissue thickness that correlates with EUC (and upwelling) strength (Fig. 5-1). Since coral tissue thickness is often used as a bio-indicator of coral resilience to stress (e.g., Thornhill et al. 2011), such observations imply that stronger upwelling is beneficial to Porites health and that corals on these highly productive reef systems may be able to withstand the stress of strong El Niño events.

Additionally, our experiments demonstrate that fed corals produce $\mathrm{CaCO}_{3}$ more rapidly than unfed corals even under elevated $\mathrm{CO}_{2}$ conditions (Chapter 3) and that elevated light appears to reduce calcification sensitivity to $\mathrm{CO}_{2}$ (Chapter 4). Holcomb et al. (2010) showed that even modest nutrient enrichments, similar in magnitude to that caused by EUC up- 
welling (Gove, unpublished data) are also capable of reducing calcification sensitivity to elevated $\mathrm{CO}_{2}$ conditions. In both cases (under elevated light or nutrients), the mechanism for $\mathrm{CO}_{2}$-sensitivity reduction appears to be closely linked, and likely attributable to enhanced symbiont photosynthesis (Langdon \& Atkinson 2005, Chapter 4). Yet the question remains, how will these different forms of nutrition interact and which will dominate in determining coral calcification response to changes in EUC upwelling? Enhanced symbiont photosynthesis due to the availability of inorganic nutrition may reduce the decline in calcification caused by $\mathrm{CO}_{2}$-rich water by as much as $100 \%$ (i.e., Langdon \& Atkinson 2005, Holcomb et al. 2010). Also, increased productivity and availability of planktonic food for coral heterotrophy could increase the baseline calcification that is otherwise lower due to high levels of inorganic nutrients. In our experiments, fed corals produced approximately $40 \%$ more $\mathrm{CaCO}_{3}$ than unfed corals under elevated $\mathrm{CO}_{2}$ conditions. Of course the balance of these contributing factors may be highly variable. For instance, if corals were to bleach, then the mechanism of reduced $\mathrm{CO}_{2}$-sensitivity conferred by symbiont photosynthesis would be lost.

This thesis presents new evidence for the historical, mechanistic drivers of EUC intensification and for the role of coral nutrition in determining calcification response under elevated $\mathrm{CO}_{2}$ conditions. My results support the overarching hypothesis that the EUC's impact on equatorial Pacific island SST and biogeochemistry will play an important role in determining the potential of these islands as climate change refugia for coral reef communities. 


\section{$5.1 \quad$ References}

Anthony KRN, Connolly SR, Hoegh-Guldberg O (2007) Bleaching, energetics, and coral mortality risk: Effects of temperature, light, and sediment regime. Limnology and Oceanography 52

Anthony KRN, Hoogenboom MO, Maynard JA, Grottoli AG, Middlebrook R (2009) Energetics approach to predicting mortality risk from environmental stress: a case study of coral bleaching. Functional Ecology 23: 539-550

Carilli J, Donner SD, Hatmann AC (2012) Historical Temperature Variability Affects Coral Response to Heat Stress. PLoS ONE 7: e34418

D'Croz L, Mate J, Oke J (2001) Responses to elevated sea water temperature and UV radiation in the coral Porites lobata from upwelling and non-upwelling environments on the Pacific coast of Panama. Bulletin of Marine Science 69: 203-214

Firing E, Lukas R, Sadler J, Wyrtki K (1983) Equatorial Undercurrent Disappears During 1982-1983 El Niño. Science 222: 1121-1123

Holcomb M, McCorkle DC, Cohen AL (2010) Long-term effects of nutrient and $\mathrm{CO}_{2}$ enrichment on the temperate coral Astrangia poculata (Ellis and Solander, 1786). Journal of Experimental Marine Biology and Ecology 386: 27-33

Karnauskas KB, Cohen AL (2012) Equatorial refuge amid tropical warming. Nature Climate Change 2: 530-534

Langdon C, Atkinson MJ (2005) Effect of elevated $\mathrm{pCO}_{2}$ on photosynthesis and calcification of corals and interactions with seasonal change in temperature/irradiance and nutrient enrichment. Journal of Geophysical Research: Oceans 110: C09S07

Luo Y, Rothstein LM, Zhang RH (2009) Response of Pacific subtropical-tropical thermocline water pathways and transports to global warming. Geophysical Research Letters 36: L04 601

Riegl B, Piller W (2003) Possible refugia for reefs in times of environmental stress. International Journal of Earth Sciences 92: 520-531

Rodrigues LJ, Grottoli A (2007) Energy reserves and metabolism as indicators of coral recovery from bleaching. Limnology and Oceanography 52: 1874-1882

Sen Gupta A, Ganachaud A, McGregor S, Brown JN, Muir L (2012) Drivers of the projected changes to the Pacific Ocean equatorial circulation. Geophysical Research Letters 39: L09 605

Thornhill D, Rotjan RD, Todd BD, Chilcoat GC, Iglesias-Prieto R, Kemp D, LaJeunesse T, McCabe Reynolds J, Schmidt G, Shannon T, Warner ME, Fitt WK (2011) A Connection between Colony Biomass and Death in Caribbean Reef-Building Corals. PLoS ONE 6: e29 535 
Veron J, Hoegh-Guldberg O, Lenton T, Lough J, Obura D, Pearce-Kelly P, Sheppard C, Spalding M, Stafford-Smith M, Rogers A (2009) The coral reef crisis: The critical importance of $<350 \mathrm{ppm} \mathrm{CO}_{2}$. Marine Pollution Bulletin 58: 1428-1436

West JM, Salm RV (2003) Resistance and Resilience to Coral Bleaching: Implications for Coral Reef Conservation and Management. Conservation Biology 17: 956-967 


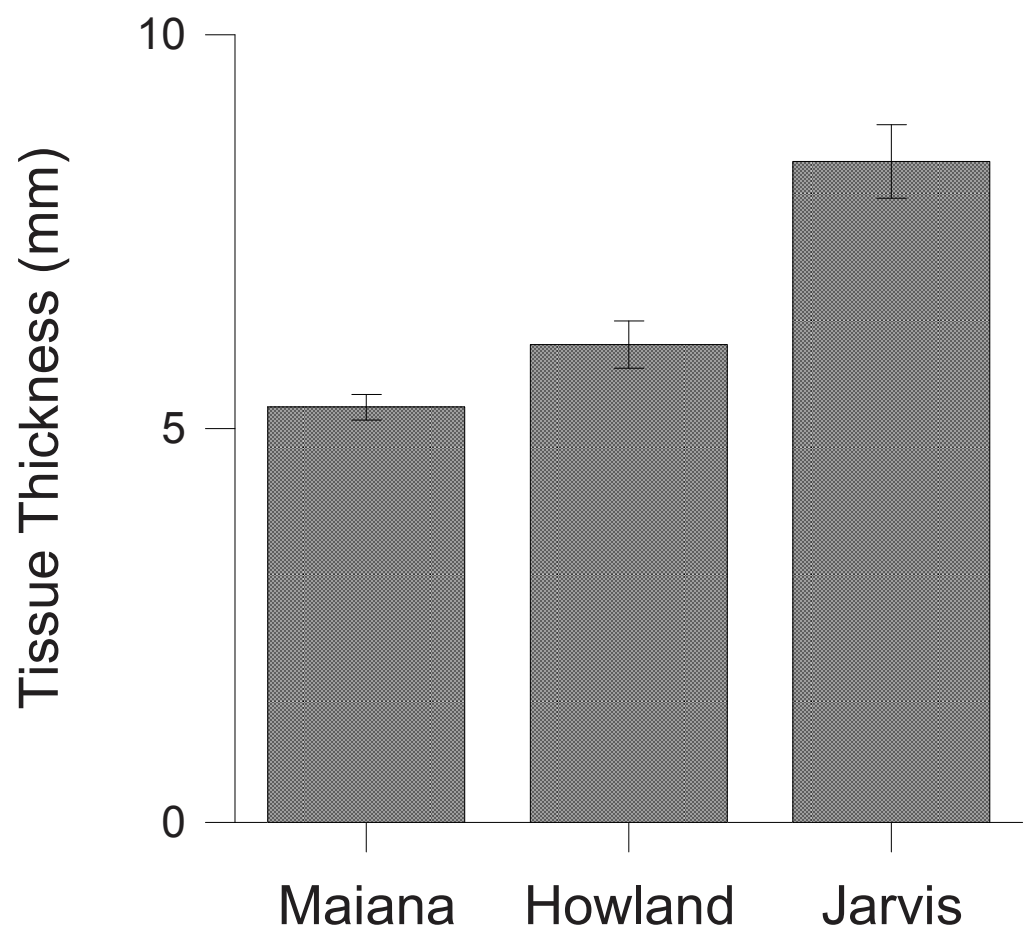

Figure 5-1: Average tissue thickness of Porites sp. collected from the equatorial Pacific islands: Maiana (Republic of Kiribati), Howland and Jarvis (both U.S. National Wildlife Refuges). All three islands are located within $2^{\circ}$ latitude of the equator and are situated along a longitudinal gradient of increasing mean-state EUC intensity: $173^{\circ} \mathrm{E}, 176.5^{\circ} \mathrm{W}$, and $160^{\circ} \mathrm{W}$ respectively. Coral samples were pneumatically cored and collected from both east and west sides of these islands (except for the eastern side of Howland where there were no Porites available for sampling). Cross-sections perpendicular to the core tops were made in order to expose the full tissue extent. These cross-sections were digitally photographed and analyzed using $\mathrm{SPOT}^{\mathrm{TM}}$ software to measure the tissue thickness. All coral samples were collected during September 2012 when EUC intensity is at a seasonal low (Johnson et al. 2012) and therefore the contrast in environmental conditions between west (i.e., upwelling) and east (i.e., non-upwelling) sides of islands due to topographic upwelling would be weakest, with both sides likely reflecting the influence of wind-driven equatorial upwelling. 


\section{Appendix A}

\section{Data for Chapter 3}

\section{A.1 2010 Skeletal Size and Weight Data}

\begin{tabular}{|c|c|c|c|c|c|c|}
\hline $\begin{array}{c}\text { Tank } \\
\text { Treatment }\end{array}$ & Tile ID & $\begin{array}{c}\text { Tile Age } \\
\text { (days) }\end{array}$ & Coralite ID & $\begin{array}{l}\text { Size } \\
(\mu \mathbf{m})\end{array}$ & $\begin{array}{c}\text { Weight } \\
(\mu \mathrm{g})\end{array}$ & $\begin{array}{c}\text { ASN Weight } \\
\left(\mu \mathrm{g} \mathrm{mm}^{-1} \text { day }^{-1}\right)\end{array}$ \\
\hline 1 & 4 & 20 & $\mathrm{~N}$ & 1274 & & \\
\hline $1670 \mathrm{ppm} \mathrm{CO}_{2}$ & & & $\mathrm{O}$ & 1708 & 437 & 16.05 \\
\hline \multirow{33}{*}{ Unfed } & & & $\mathrm{T}$ & 1253 & 159 & 5.84 \\
\hline & & & $\mathrm{W}$ & 1321 & 169 & 6.21 \\
\hline & & & $\mathrm{Y}$ & 1714 & 422 & 15.50 \\
\hline & 5 & 20 & $\mathrm{~A}$ & 1316 & 216 & 7.93 \\
\hline & & & B & 1440 & 296 & 10.87 \\
\hline & & & $\mathrm{C}$ & 1224 & 187 & 6.87 \\
\hline & & & $\mathrm{D}$ & 1094 & 146 & 5.36 \\
\hline & & & $\mathrm{E}$ & 1493 & 329 & 12.08 \\
\hline & & & $\mathrm{F}$ & 1150 & 161 & 5.91 \\
\hline & & & $\mathrm{H}$ & 1357 & 226 & 8.30 \\
\hline & & & $\mathrm{J}$ & 1474 & 308 & 11.31 \\
\hline & & & $\mathrm{K}$ & 1340 & 259 & 9.51 \\
\hline & & & $\mathrm{L}$ & 1322 & 187 & 6.87 \\
\hline & & & M & 1533 & 301 & 11.05 \\
\hline & & & $\mathrm{N}$ & 1331 & 189 & 6.94 \\
\hline & & & $\mathrm{O}$ & 1545 & 280 & 10.28 \\
\hline & & & $\mathrm{P}$ & 1340 & 245 & 9.00 \\
\hline & & & Q & 1699 & 451 & 16.56 \\
\hline & & & $\mathrm{R}$ & 1254 & 198 & 7.27 \\
\hline & $6 \mathrm{~B}$ & 21 & $\mathrm{~A}$ & 1337 & 298 & 10.42 \\
\hline & & & B & 1118 & 158 & 5.53 \\
\hline & & & $\mathrm{C}$ & 1345 & 276 & 9.65 \\
\hline & & & $\mathrm{F}$ & 1073 & 306 & 10.70 \\
\hline & & & I & 1278 & & \\
\hline & & & $\mathrm{J}$ & & 201 & 7.03 \\
\hline & & & $\mathrm{K}$ & 1374 & 267 & 9.34 \\
\hline & & & $\mathrm{L}$ & 1447 & 319 & 11.16 \\
\hline & 7 & 21 & $\mathrm{~A}$ & 1401 & 262 & 9.16 \\
\hline & & & B & & 261 & 9.13 \\
\hline & & & $\mathrm{C}$ & 1452 & 330 & 11.54 \\
\hline & & & $\mathrm{D}$ & 1171 & & \\
\hline & & & $\mathrm{E}$ & 1496 & & \\
\hline & & & G & 1349 & 264 & 9.23 \\
\hline
\end{tabular}


2010 skeletal size and weight data, continued

\begin{tabular}{|c|c|c|c|c|c|c|}
\hline $\begin{array}{c}\text { Tank } \\
\text { Treatment }\end{array}$ & Tile ID & $\begin{array}{c}\text { Tile Age } \\
\text { (days) }\end{array}$ & Coralite ID & $\begin{array}{l}\text { Size } \\
(\mu \mathrm{m})\end{array}$ & $\begin{array}{c}\text { Weight } \\
(\mu \mathrm{g})\end{array}$ & $\begin{array}{c}\text { ASN Weight } \\
\left(\mu \mathrm{g} \mathrm{mm}^{-1} \text { day }^{-1}\right)\end{array}$ \\
\hline & & & $\mathrm{H}$ & 1424 & 376 & 13.15 \\
\hline & & & I & 1210 & 192 & 6.72 \\
\hline & & & $\mathrm{J}$ & 1591 & 337 & 11.79 \\
\hline & & & $\mathrm{K}$ & 1256 & 238 & 8.32 \\
\hline & & & $\mathrm{L}$ & 1385 & 257 & 8.99 \\
\hline & & & M & 1207 & 212 & 7.42 \\
\hline Tank 1 Average & & & & 1361 & 263 & 9.43 \\
\hline 2 & 4 & 21 & $\mathrm{H}$ & 2351 & 614 & 14.07 \\
\hline $420 \mathrm{ppm} \mathrm{CO}_{2}$ & & & $\mathrm{P}$ & 1491 & 256 & 5.87 \\
\hline \multirow[t]{31}{*}{ Fed } & & & $\mathrm{Q} / \mathrm{U}$ & 2116 & 546 & 12.51 \\
\hline & & & $\mathrm{R}$ & 2070 & 498 & 11.41 \\
\hline & & & $\mathrm{S}$ & 2070 & 475 & 10.88 \\
\hline & & & V & 2050 & 565 & 12.94 \\
\hline & 5 & 22 & $\mathrm{~B}$ & 2275 & 632 & 13.82 \\
\hline & & & $\mathrm{C}$ & 2070 & 474 & 10.37 \\
\hline & & & $\mathrm{D}$ & 2487 & 642 & 14.04 \\
\hline & & & $\mathrm{E}$ & 2502 & 730 & 15.96 \\
\hline & & & $\mathrm{F}$ & 2153 & 647 & 14.15 \\
\hline & & & $\mathrm{H}$ & 2218 & 665 & 14.54 \\
\hline & & & I & 2281 & 631 & 13.80 \\
\hline & & & M & 1945 & 503 & 11.00 \\
\hline & & & $\mathrm{N}$ & 2676 & 762 & 16.66 \\
\hline & & & $\mathrm{O}$ & 2424 & 738 & 16.14 \\
\hline & & & $\mathrm{P}$ & 1989 & 490 & 10.72 \\
\hline & & & $\mathrm{Y}$ & 2392 & 771 & 16.86 \\
\hline & & & $\mathrm{AB}$ & 2253 & 696 & 15.22 \\
\hline & & & $\mathrm{AE}$ & 2375 & 732 & 16.01 \\
\hline & & & $\mathrm{AL}$ & & 387 & 8.46 \\
\hline & & & $\mathrm{AM}$ & 2323 & 702 & 15.35 \\
\hline & & & $\mathrm{AN}$ & 1745 & 344 & 7.52 \\
\hline & & & $\mathrm{AQ}$ & 2398 & 718 & 15.70 \\
\hline & & & $\mathrm{AU}$ & 2183 & 627 & 13.71 \\
\hline & & & $\mathrm{AV}$ & 1729 & 394 & 8.62 \\
\hline & & & AW & 2469 & & \\
\hline & & & $\mathrm{AX}$ & 2040 & 538 & 11.77 \\
\hline & & & $\mathrm{AZ}$ & 2314 & 655 & 14.32 \\
\hline & & & BA & 2254 & 506 & 11.07 \\
\hline & 7 & 21 & $\mathrm{~A}$ & 1786 & 340 & 7.79 \\
\hline & & & B & 1543 & 222 & 5.09 \\
\hline & & & I & 1962 & 356 & 8.16 \\
\hline
\end{tabular}


2010 skeletal size and weight data, continued

\begin{tabular}{|c|c|c|c|c|c|c|}
\hline $\begin{array}{c}\text { Tank } \\
\text { Treatment }\end{array}$ & Tile ID & $\begin{array}{c}\text { Tile Age } \\
\text { (days) }\end{array}$ & Coralite ID & $\begin{array}{l}\text { Size } \\
(\mu \mathrm{m})\end{array}$ & $\begin{array}{c}\text { Weight } \\
(\mu \mathrm{g})\end{array}$ & $\begin{array}{c}\text { ASN Weight } \\
\left(\mu \mathrm{g} \mathrm{mm}^{-1} \text { day }^{-1}\right)\end{array}$ \\
\hline & & & $\mathrm{K}$ & 1742 & & \\
\hline & & & $\mathrm{L}$ & 1978 & 213 & 4.88 \\
\hline & & & M & 2503 & 665 & 15.24 \\
\hline & & & $\mathrm{N}$ & 1762 & & \\
\hline & & & $\mathrm{O}$ & 2150 & 499 & 11.43 \\
\hline & & & $\mathrm{P}$ & 1866 & 448 & 10.26 \\
\hline & & & $\mathrm{Q}$ & 2331 & 636 & 14.57 \\
\hline & & & $\mathrm{R}$ & 2088 & 409 & 9.37 \\
\hline & & & $\mathrm{S}$ & 1869 & 185 & 4.24 \\
\hline & & & $\mathrm{T}$ & 1600 & 336 & 7.70 \\
\hline & & & $\mathrm{U}$ & 1144 & 178 & 4.08 \\
\hline & & & $\mathrm{V}$ & 1487 & 299 & 6.85 \\
\hline Tank 2 Average & & & & 2078 & 517 & 11.50 \\
\hline 3 & 4 & 20 & $\mathrm{~A}$ & 1442 & 384 & 13.37 \\
\hline $420 \mathrm{ppm} \mathrm{CO}_{2}$ & & & I & 1377 & 368 & 12.81 \\
\hline \multirow[t]{25}{*}{ Unfed } & & & $\mathrm{K}$ & 1387 & 431 & 15.00 \\
\hline & 5 & 22 & $\mathrm{E}$ & 1118 & 221 & 6.99 \\
\hline & & & $\mathrm{F}$ & 1595 & 449 & 14.21 \\
\hline & & & G & 1018 & 184 & 5.82 \\
\hline & & & $\mathrm{H}$ & 1641 & & \\
\hline & & & $\mathrm{P}$ & 1592 & 503 & 15.92 \\
\hline & & & $\mathrm{Q}$ & 1568 & 477 & 15.09 \\
\hline & & & $\mathrm{R}$ & 1426 & 318 & 10.06 \\
\hline & & & $\mathrm{X}$ & 1416 & 358 & 11.33 \\
\hline & & & $\mathrm{AB}$ & 1455 & 337 & 10.66 \\
\hline & & & $\mathrm{AD}$ & & 244 & 7.72 \\
\hline & & & $\mathrm{AF}$ & 1494 & 405 & 12.82 \\
\hline & & & $\mathrm{AH}$ & & 270 & 8.54 \\
\hline & & & AI & 1571 & 473 & 14.97 \\
\hline & & & $\mathrm{AA}$ & 1631 & 509 & 16.11 \\
\hline & & & $\mathrm{U}$ & 1504 & 395 & 12.50 \\
\hline & & & $\mathrm{W}$ & 1759 & 552 & 17.47 \\
\hline & & & AJ & 1712 & 604 & 19.11 \\
\hline & & & $\mathrm{AM}$ & 1823 & 630 & 19.94 \\
\hline & & & $\mathrm{AK}$ & 1309 & 312 & 9.87 \\
\hline & & & $\mathrm{AP}$ & 1385 & 306 & 9.68 \\
\hline & & & $\mathrm{AQ}$ & 1663 & 514 & 16.27 \\
\hline & & & $\mathrm{AR}$ & 1246 & 311 & 9.84 \\
\hline & & & $\mathrm{AS}$ & 1133 & 226 & 7.15 \\
\hline & & & $\mathrm{AU}$ & 1334 & 322 & 10.19 \\
\hline
\end{tabular}


2010 skeletal size and weight data, continued

\begin{tabular}{|c|c|c|c|c|c|c|}
\hline $\begin{array}{c}\text { Tank } \\
\text { Treatment }\end{array}$ & Tile ID & $\begin{array}{c}\text { Tile Age } \\
\text { (days) }\end{array}$ & Coralite ID & $\begin{array}{l}\text { Size } \\
(\mu \mathbf{m})\end{array}$ & $\begin{array}{c}\text { Weight } \\
(\mu \mathrm{g})\end{array}$ & $\begin{array}{c}\text { ASN Weight } \\
\left(\mu \mathrm{g} \mathrm{mm}^{-1} \text { day }^{-1}\right)\end{array}$ \\
\hline & & & AW & 1498 & 432 & 13.67 \\
\hline & & & AY & 1411 & 387 & 12.25 \\
\hline & & & BA & 1565 & 419 & 13.26 \\
\hline & & & $\mathrm{BC}$ & 1537 & 446 & 14.11 \\
\hline & & & $\mathrm{BB}$ & 1541 & 440 & 13.92 \\
\hline & & & $\mathrm{BD}$ & 1476 & 324 & 10.25 \\
\hline & 8 & 21 & $\mathrm{~A}$ & 1406 & 362 & 12.00 \\
\hline & & & B & 999 & 173 & 5.74 \\
\hline & & & $\mathrm{D}$ & 1602 & 474 & 15.71 \\
\hline & & & $\mathrm{H}$ & 1370 & & \\
\hline & & & I & 1555 & & \\
\hline & & & $\mathrm{J}$ & 1334 & & \\
\hline & & & $\mathrm{K}$ & & 283 & 9.38 \\
\hline & & & $\mathrm{L}$ & 1153 & 214 & 7.09 \\
\hline & & & M & 1453 & 365 & 12.10 \\
\hline & & & $\mathrm{N}$ & 1458 & 379 & 12.56 \\
\hline & & & $\mathrm{O}$ & 1508 & 418 & 13.86 \\
\hline & & & $\mathrm{P}$ & 1860 & 545 & 18.07 \\
\hline & & & $\mathrm{Q}$ & 1525 & 464 & 15.38 \\
\hline & & & $\mathrm{R}$ & 1524 & & \\
\hline & & & $\mathrm{S}$ & 1458 & 317 & 10.51 \\
\hline & & & $\mathrm{T}$ & & 318 & 10.54 \\
\hline & & & V & 1286 & 336 & 11.14 \\
\hline & & & $\mathrm{W}$ & 1462 & 395 & 13.10 \\
\hline & & & $\mathrm{X}$ & 1569 & & \\
\hline & & & $\mathrm{Y}$ & 1392 & 373 & 12.37 \\
\hline & & & $\mathrm{Z}$ & 1430 & & \\
\hline & & & $\mathrm{AA}$ & 978 & 138 & 4.58 \\
\hline & & & $\mathrm{AB}$ & 1543 & & \\
\hline & & & $\mathrm{AC}$ & 1427 & & \\
\hline & & & $\mathrm{AD}$ & 1509 & 477 & 15.81 \\
\hline & & & $\mathrm{AE}$ & 1425 & 363 & 12.03 \\
\hline & & & $\mathrm{AF}$ & 1249 & 250 & 8.29 \\
\hline & & & $\mathrm{AG}$ & 1427 & 372 & 12.33 \\
\hline & & & $\mathrm{AH}$ & 1314 & 325 & 10.77 \\
\hline & & & $\mathrm{AI}$ & 1523 & 424 & 14.06 \\
\hline & & & AJ & 819 & 111 & 3.68 \\
\hline Tank 3 Average & & & & 1436 & 371 & 12.04 \\
\hline 4 & 3 & 21 & $\mathrm{~B}$ & 1280 & & \\
\hline $1670 \mathrm{ppm} \mathrm{CO}_{2}$ & & & $\mathrm{C}$ & 1263 & & \\
\hline
\end{tabular}


2010 skeletal size and weight data, continued

\begin{tabular}{|c|c|c|c|c|c|c|}
\hline $\begin{array}{c}\text { Tank } \\
\text { Treatment }\end{array}$ & Tile ID & $\begin{array}{c}\text { Tile Age } \\
\text { (days) }\end{array}$ & Coralite ID & $\begin{array}{l}\text { Size } \\
(\mu \mathrm{m})\end{array}$ & $\begin{array}{c}\text { Weight } \\
(\mu \mathrm{g})\end{array}$ & $\begin{array}{c}\text { ASN Weight } \\
\left(\mu \mathbf{g ~ m m}^{-1} \text { day }^{-1}\right)\end{array}$ \\
\hline \multirow[t]{31}{*}{ Unfed } & & & $\mathrm{D}$ & 1156 & & \\
\hline & & & $\mathrm{E}$ & 1308 & 232 & 8.31 \\
\hline & & & $\mathrm{F}$ & 1379 & 181 & 6.48 \\
\hline & & & G & 1120 & 178 & 6.38 \\
\hline & & & $\mathrm{H}$ & & 162 & 5.80 \\
\hline & & & I & 1215 & 182 & 6.52 \\
\hline & & & K & 1308 & 186 & 6.66 \\
\hline & & & $\mathrm{L}$ & 1561 & 159 & 5.70 \\
\hline & & & M & 1332 & 221 & 7.92 \\
\hline & & & $\mathrm{N}$ & 1424 & 331 & 11.86 \\
\hline & & & $\mathrm{O}$ & 1245 & 207 & 7.42 \\
\hline & & & $\mathrm{P}$ & 1292 & 228 & 8.17 \\
\hline & & & $\mathrm{Q}$ & 1404 & 294 & 10.53 \\
\hline & & & $\mathrm{R}$ & 1281 & 217 & 7.77 \\
\hline & 5 & 22 & $\mathrm{E}$ & 1482 & & \\
\hline & & & $\mathrm{F}$ & 1413 & 230 & 7.86 \\
\hline & & & G & 1515 & 297 & 10.16 \\
\hline & & & $\mathrm{H}$ & 1443 & 306 & 10.46 \\
\hline & & & K & & 178 & 6.09 \\
\hline & & & $\mathrm{L}$ & 1456 & 292 & 9.99 \\
\hline & & & M & 1410 & & \\
\hline & & & $\mathrm{O}$ & 1103 & 152 & 5.20 \\
\hline & & & $\mathrm{Q}$ & 1407 & 286 & 9.78 \\
\hline & & & $\mathrm{R}$ & 1265 & 251 & 8.58 \\
\hline & 7 & 20 & $\mathrm{~B}$ & 1254 & 191 & 7.18 \\
\hline & & & $\mathrm{C}$ & 1404 & 343 & 12.90 \\
\hline & & & $\mathrm{D}$ & 1343 & 291 & 10.95 \\
\hline & & & $\mathrm{E}$ & 1195 & 194 & 7.30 \\
\hline & & & G & 1503 & 338 & 12.71 \\
\hline & 8 & 21 & $\mathrm{~A}$ & 1305 & 266 & 9.53 \\
\hline & & & B & 1143 & & \\
\hline Tank 4 Average & & & & 1329 & 237 & 8.45 \\
\hline 5 & 4 & 21 & I & 2535 & & \\
\hline $1670 \mathrm{ppm} \mathrm{CO}_{2}$ & & & $\mathrm{~J}$ & 1846 & 318 & 7.52 \\
\hline Fed & & & $\mathrm{L}$ & 2476 & 552 & 13.05 \\
\hline & 5 & 21 & $\mathrm{E}$ & 2319 & 422 & 9.98 \\
\hline & 8 & 23 & $\mathrm{~A}$ & 2031 & 394 & 8.51 \\
\hline & & & B & 2073 & 497 & 10.73 \\
\hline & & & $\mathrm{D}$ & 2110 & 401 & 8.66 \\
\hline & 10 & 21 & $\mathrm{~A}$ & 1684 & 245 & 5.79 \\
\hline
\end{tabular}


2010 skeletal size and weight data, continued

\begin{tabular}{|c|c|c|c|c|c|c|}
\hline $\begin{array}{c}\text { Tank } \\
\text { Treatment }\end{array}$ & Tile ID & $\begin{array}{l}\text { Tile Age } \\
\text { (days) }\end{array}$ & Coralite ID & $\begin{array}{l}\text { Size } \\
(\mu \mathrm{m})\end{array}$ & $\begin{array}{c}\text { Weight } \\
(\mu \mathrm{g})\end{array}$ & $\begin{array}{c}\text { ASN Weight } \\
\left(\mu \mathrm{g} \mathrm{mm}^{-1} \text { day }^{-1}\right)\end{array}$ \\
\hline & & & $\mathrm{B}$ & 2081 & 442 & 10.45 \\
\hline & & & $\mathrm{C}$ & 1745 & 259 & 6.12 \\
\hline & & & $\mathrm{D}$ & 1718 & 269 & 6.36 \\
\hline & & & $\mathrm{E}$ & 1550 & 218 & 5.15 \\
\hline Tank 5 Average & & & & 2014 & 365 & 8.39 \\
\hline 6 & 6 & 22 & $\mathrm{~A}$ & 1397 & 308 & 10.27 \\
\hline $420 \mathrm{ppm} \mathrm{CO}_{2}$ & & & $\mathrm{AB}$ & 1331 & 276 & 9.20 \\
\hline \multirow[t]{33}{*}{ Unfed } & & & B & 1808 & 573 & 19.10 \\
\hline & & & $\mathrm{D}$ & 1575 & 460 & 15.33 \\
\hline & & & $\mathrm{E}$ & 1425 & 377 & 12.57 \\
\hline & & & $\mathrm{F}$ & 1382 & 365 & 12.17 \\
\hline & & & $\mathrm{H}$ & 1333 & 326 & 10.87 \\
\hline & & & K & 1394 & 365 & 12.17 \\
\hline & & & $\mathrm{L}$ & 1490 & & \\
\hline & & & $\mathrm{O}$ & 1413 & 427 & 14.23 \\
\hline & & & $\mathrm{S}$ & 1369 & 348 & 11.60 \\
\hline & & & $\mathrm{U}$ & 949 & 210 & 7.00 \\
\hline & & & V & 1460 & 428 & 14.27 \\
\hline & & & $\mathrm{C}$ & 1200 & 240 & 8.00 \\
\hline & & & $\mathrm{AC}$ & 1250 & 292 & 9.73 \\
\hline & & & $\mathrm{AH}$ & 1467 & 438 & 14.60 \\
\hline & & & $\mathrm{AL}$ & 1229 & & \\
\hline & & & $\mathrm{AE}$ & 1428 & 275 & 9.17 \\
\hline & & & $\mathrm{AF}$ & 1266 & 375 & 12.50 \\
\hline & 7 & 20 & $\mathrm{~A}$ & 1573 & 379 & 13.90 \\
\hline & & & B & 1372 & 269 & 9.86 \\
\hline & & & $\mathrm{C}$ & 1457 & & \\
\hline & & & $\mathrm{D}$ & 1538 & 305 & 11.18 \\
\hline & & & $\mathrm{F}$ & 1509 & 350 & 12.83 \\
\hline & & & $\mathrm{J}$ & 1566 & 374 & 13.71 \\
\hline & & & K & 1056 & & \\
\hline & & & $\mathrm{L}$ & 1133 & & \\
\hline & & & $\mathrm{N}$ & 1166 & & \\
\hline & & & $\mathrm{O}$ & 1268 & & \\
\hline & & & $\mathrm{Q}$ & 1261 & 288 & 10.56 \\
\hline & & & $\mathrm{R}$ & & 252 & 9.24 \\
\hline & & & $\mathrm{AA}$ & 1545 & 464 & 17.01 \\
\hline & & & $\mathrm{AC}$ & 1297 & 293 & 10.74 \\
\hline & & & $\mathrm{AD}$ & & 252 & 9.24 \\
\hline & & & $\mathrm{AE}$ & 1221 & & \\
\hline
\end{tabular}


2010 skeletal size and weight data, continued

\begin{tabular}{|c|c|c|c|c|c|c|}
\hline $\begin{array}{c}\text { Tank } \\
\text { Treatment }\end{array}$ & Tile ID & $\begin{array}{c}\text { Tile Age } \\
\text { (days) }\end{array}$ & Coralite ID & $\begin{array}{l}\text { Size } \\
(\mu \mathrm{m})\end{array}$ & $\begin{array}{c}\text { Weight } \\
(\mu \mathrm{g})\end{array}$ & $\begin{array}{c}\text { ASN Weight } \\
\left(\mu \mathrm{g} \mathrm{mm}^{-1} \text { day }^{-1}\right)\end{array}$ \\
\hline & & & $\mathrm{AF}$ & 1239 & & \\
\hline Tank 6 Average & & & & 1364 & 345 & 11.89 \\
\hline 7 & 3 & 20 & $\mathrm{~K}$ & 1440 & 425 & 15.52 \\
\hline $420 \mathrm{ppm} \mathrm{CO}_{2}$ & & & $\mathrm{O}$ & 1263 & 257 & 9.38 \\
\hline \multirow[t]{36}{*}{ Unfed } & & & $\mathrm{P}$ & 1577 & 451 & 16.47 \\
\hline & & & $\mathrm{T}$ & 1599 & 386 & 14.09 \\
\hline & & & $\mathrm{U}$ & 1160 & 193 & 7.05 \\
\hline & & & V & 1376 & 340 & 12.41 \\
\hline & & & $\mathrm{Y}$ & 1554 & 432 & 15.77 \\
\hline & & & $\mathrm{Z}$ & 1495 & 449 & 16.39 \\
\hline & & & $\mathrm{AB}$ & 1164 & 253 & 9.24 \\
\hline & 6 & 22 & $\mathrm{~A}$ & 1415 & 440 & 14.60 \\
\hline & & & $\mathrm{AA}$ & 1286 & 311 & 10.32 \\
\hline & & & B & 1533 & 446 & 14.80 \\
\hline & & & $\mathrm{F}$ & 1497 & 465 & 15.43 \\
\hline & & & G & 1381 & 287 & 9.53 \\
\hline & & & $\mathrm{H}$ & 1548 & & \\
\hline & & & $\mathrm{J}$ & 1461 & 407 & 13.51 \\
\hline & & & K & 1423 & 400 & 13.28 \\
\hline & & & $\mathrm{L}$ & 1345 & 309 & 10.26 \\
\hline & & & M & 1200 & 295 & 9.79 \\
\hline & & & $\mathrm{N}$ & 1583 & & \\
\hline & & & $\mathrm{P}$ & 1171 & 252 & 8.36 \\
\hline & & & $\mathrm{S}$ & 1350 & 339 & 11.25 \\
\hline & & & $\mathrm{U}$ & 1195 & 268 & 8.90 \\
\hline & & & $\mathrm{X}$ & 1241 & 295 & 9.79 \\
\hline & & & $\mathrm{Z}$ & 1460 & 464 & 15.40 \\
\hline & & & $\mathrm{D}$ & 1536 & 393 & 13.04 \\
\hline & 7 & 21 & $\mathrm{~A}$ & 1396 & 309 & 10.74 \\
\hline & & & B & 1489 & 456 & 15.86 \\
\hline & & & $\mathrm{C}$ & 1361 & 312 & 10.85 \\
\hline & & & $\mathrm{D}$ & 1601 & 464 & 16.13 \\
\hline & & & $\mathrm{E}$ & 1285 & 240 & 8.35 \\
\hline & & & $\mathrm{F}$ & 1145 & 210 & 7.30 \\
\hline & & & G & & 272 & 9.46 \\
\hline & & & $\mathrm{H}$ & 1250 & 274 & 9.53 \\
\hline & & & I & 1385 & 321 & 11.16 \\
\hline & & & $\mathrm{J}$ & 1214 & 233 & 8.10 \\
\hline & & & $\mathrm{K}$ & 1479 & 383 & 13.32 \\
\hline & & & $\mathrm{L}$ & & 263 & 9.15 \\
\hline
\end{tabular}


2010 skeletal size and weight data, continued

\begin{tabular}{|c|c|c|c|c|c|c|}
\hline $\begin{array}{c}\text { Tank } \\
\text { Treatment }\end{array}$ & Tile ID & $\begin{array}{c}\text { Tile Age } \\
\text { (days) }\end{array}$ & Coralite ID & $\begin{array}{l}\text { Size } \\
(\mu \mathbf{m})\end{array}$ & $\begin{array}{c}\text { Weight } \\
(\mu \mathrm{g})\end{array}$ & $\begin{array}{c}\text { ASN Weight } \\
\left(\mu \mathrm{g} \mathrm{mm}^{-1} \text { day }^{-1}\right)\end{array}$ \\
\hline & & & $\mathrm{M}$ & 1249 & 247 & 8.59 \\
\hline & & & $\mathrm{N}$ & & 283 & 9.84 \\
\hline & & & $\mathrm{O}$ & 1390 & & \\
\hline & & & $\mathrm{P}$ & 1060 & 461 & 16.03 \\
\hline & & & $\mathrm{Q}$ & 1579 & 391 & 13.60 \\
\hline & 10 & 22 & $\mathrm{C}$ & 1323 & 326 & 10.82 \\
\hline & & & $\mathrm{D}$ & 1061 & 224 & 7.43 \\
\hline Tank 7 Average & & & & 1369 & 339 & 11.69 \\
\hline 8 & 4 & 21 & $\mathrm{~K}$ & 1230 & & \\
\hline $1670 \mathrm{ppm} \mathrm{CO}_{2}$ & & & $\mathrm{~L}$ & 1425 & 327 & 12.19 \\
\hline \multirow[t]{29}{*}{ Unfed } & & & $\mathrm{P}$ & 1289 & & \\
\hline & & & Q & 1631 & 402 & 14.99 \\
\hline & & & $\mathrm{R}$ & 1383 & 300 & 11.18 \\
\hline & & & S & 1534 & 357 & 13.31 \\
\hline & 5 & 21 & A & 1396 & 237 & 8.83 \\
\hline & & & $\mathrm{D}$ & 1147 & 206 & 7.68 \\
\hline & & & $\mathrm{F}$ & & 224 & 8.35 \\
\hline & & & I & 1084 & 165 & 6.15 \\
\hline & & & M & 1087 & 207 & 7.72 \\
\hline & & & $\mathrm{N}$ & 1268 & & \\
\hline & & & $\mathrm{O}$ & 1526 & 328 & 12.23 \\
\hline & & & $\mathrm{P}$ & 1289 & 298 & 11.11 \\
\hline & 6 & 20 & $\mathrm{E}$ & 1448 & 386 & 15.11 \\
\hline & & & $\mathrm{F}$ & 1456 & 289 & 11.31 \\
\hline & & & G & 1304 & 172 & 6.73 \\
\hline & & & $\mathrm{H}$ & 1464 & 293 & 11.47 \\
\hline & & & I & 1165 & 197 & 7.71 \\
\hline & & & $\mathrm{K}$ & 1405 & 243 & 9.51 \\
\hline & & & $\mathrm{L}$ & 1135 & 200 & 7.83 \\
\hline & & & $\mathrm{O}$ & 1247 & 197 & 7.71 \\
\hline & 7 & 22 & A & 1303 & 224 & 7.97 \\
\hline & & & B & 1401 & 291 & 10.35 \\
\hline & & & $\mathrm{C}$ & 850 & 109 & 3.88 \\
\hline & & & $\mathrm{D}$ & 1113 & 166 & 5.91 \\
\hline & 9 & 21 & $\mathrm{C}$ & 1148 & 217 & 8.09 \\
\hline & & & $\mathrm{D}$ & 988 & 150 & 5.59 \\
\hline & & & UNNAMED & 977 & & \\
\hline & 12 & 20 & $\mathrm{~A}$ & 1508 & 343 & 13.43 \\
\hline & & & B & 1123 & & \\
\hline Tank 8 Average & & & & 1277 & 251 & 9.47 \\
\hline
\end{tabular}


2010 skeletal size and weight data, continued

\begin{tabular}{|c|c|c|c|c|c|c|}
\hline $\begin{array}{c}\text { Tank } \\
\text { Treatment }\end{array}$ & Tile ID & $\begin{array}{l}\text { Tile Age } \\
\text { (days) }\end{array}$ & Coralite ID & $\begin{array}{l}\text { Size } \\
(\mu \mathbf{m})\end{array}$ & $\begin{array}{c}\text { Weight } \\
(\mu \mathrm{g})\end{array}$ & $\begin{array}{c}\text { ASN Weight } \\
\left(\mu \mathbf{g ~ m m}^{-1} \text { day }^{-1}\right)\end{array}$ \\
\hline 9 & 4 & 21 & $\mathrm{~A}$ & 2324 & & \\
\hline $1670 \mathrm{ppm} \mathrm{CO}_{2}$ & & & $\mathrm{D}$ & 2887 & 786 & 18.07 \\
\hline \multirow[t]{12}{*}{ Fed } & & & $\mathrm{F}$ & 1728 & 263 & 6.05 \\
\hline & & & $\mathrm{K}$ & 1898 & & \\
\hline & 6 & 21 & $\mathrm{~B}$ & 2773 & 622 & 14.30 \\
\hline & & & $\mathrm{C}$ & 2010 & 452 & 10.39 \\
\hline & & & $\mathrm{D}$ & & 202 & 4.64 \\
\hline & & & $\mathrm{F}$ & 2032 & 439 & 10.09 \\
\hline & 9 & 23 & $\mathrm{~A}$ & 1706 & 296 & 6.21 \\
\hline & & & $\mathrm{B}$ & 2181 & 559 & 11.73 \\
\hline & & & $\mathrm{C}$ & 1421 & 191 & 4.01 \\
\hline & 10 & 21 & $\mathrm{~A}$ & 1743 & & \\
\hline & & & B & 2197 & 525 & 12.07 \\
\hline & & & $\mathrm{C}$ & 2027 & 444 & 10.21 \\
\hline Tank 9 Average & & & & 2071 & 434 & 9.80 \\
\hline 10 & 3 & 21 & $\mathrm{~A}$ & 2666 & 746 & 16.73 \\
\hline $420 \mathrm{ppm} \mathrm{CO}_{2}$ & & & $\mathrm{~B}$ & 2685 & 643 & 14.42 \\
\hline \multirow[t]{9}{*}{ Fed } & & & $\mathrm{C}$ & & 575 & 12.90 \\
\hline & & & $\mathrm{D}$ & 2319 & 578 & 12.96 \\
\hline & 10 & 21 & $\mathrm{~A}$ & 2131 & 524 & 11.75 \\
\hline & & & B & 1675 & 358 & 8.03 \\
\hline & & & $\mathrm{D}$ & 1731 & 348 & 7.81 \\
\hline & & & $\mathrm{E}$ & 1866 & 491 & 11.01 \\
\hline & & & $\mathrm{F}$ & 2312 & 781 & 17.52 \\
\hline & & & $\mathrm{H}$ & 1510 & 329 & 7.38 \\
\hline & & & I & 2336 & 617 & 13.84 \\
\hline Tank 10 Average & & & & 2123 & 545 & 12.21 \\
\hline 11 & 3 & 20 & $\mathrm{H}$ & 2327 & 617 & 14.04 \\
\hline $420 \mathrm{ppm} \mathrm{CO}_{2}$ & & & $\mathrm{~K}$ & & 694 & 15.79 \\
\hline \multirow[t]{10}{*}{ Fed } & & & $\mathrm{L}$ & 2672 & 830 & 18.89 \\
\hline & & & $\mathrm{P}$ & 2882 & 806 & 18.34 \\
\hline & & & Q & 2497 & 747 & 17.00 \\
\hline & & & $\mathrm{R}$ & 2079 & & \\
\hline & & & $\mathrm{U}$ & 2085 & 492 & 11.20 \\
\hline & & & $\mathrm{AP}$ & 2434 & 696 & 15.84 \\
\hline & & & $\mathrm{AQ}$ & 1735 & 412 & 9.38 \\
\hline & & & $\mathrm{AR}$ & & 474 & 10.79 \\
\hline & & & $\mathrm{E}$ & 1607 & 313 & 7.12 \\
\hline & 7 & 21 & I & 1652 & 280 & 6.07 \\
\hline Tank 11 Average & & & & 2197 & 578 & 13.13 \\
\hline
\end{tabular}


2010 skeletal size and weight data, continued

\begin{tabular}{|c|c|c|c|c|c|c|}
\hline $\begin{array}{c}\text { Tank } \\
\text { Treatment }\end{array}$ & Tile ID & $\begin{array}{c}\text { Tile Age } \\
\text { (days) }\end{array}$ & Coralite ID & $\begin{array}{l}\text { Size } \\
(\mu \mathrm{m})\end{array}$ & $\begin{array}{c}\text { Weight } \\
(\mu \mathrm{g})\end{array}$ & $\begin{array}{c}\text { ASN Weight } \\
\left(\mu \mathbf{g ~ m m}^{-1} \text { day }^{-1}\right)\end{array}$ \\
\hline 12 & 4 & 22 & $\mathrm{I}$ & 2301 & 595 & 12.87 \\
\hline $1670 \mathrm{ppm} \mathrm{CO}_{2}$ & & & $\mathrm{~J}$ & 1819 & 341 & 7.38 \\
\hline \multirow[t]{10}{*}{ Fed } & & & $\mathrm{O}$ & 2413 & 509 & 11.01 \\
\hline & & & $\mathrm{P}$ & 2297 & 484 & 10.47 \\
\hline & & & $\mathrm{Q}$ & 1847 & 360 & 7.79 \\
\hline & & & $\mathrm{R}$ & 1662 & 207 & 4.48 \\
\hline & & & $\mathrm{U}$ & & 765 & 16.55 \\
\hline & 5 & 22 & $\mathrm{E}$ & 2523 & 654 & 14.15 \\
\hline & & & G & 2519 & 565 & 12.23 \\
\hline & & & $\mathrm{I}$ & 2171 & 340 & 7.36 \\
\hline & 8 & 20 & A & 1689 & 330 & 7.85 \\
\hline & & & B & 1868 & 417 & 9.93 \\
\hline Tank 12 Average & & & & 2101 & 464 & 10.17 \\
\hline
\end{tabular}

Table A.1: Skeletal size (i.e., septa diameter), Weight (i.e., mass $\mathrm{CaCO}_{3}$ ), and Age-and SizeNormalized (ASN) weight of juvenile Favia fragum from the $2010 \mathrm{CO}_{2} \times$ Feeding experiment. ASN Weight is the total mass of $\mathrm{CaCO}_{3}$ for the sample divided by the average skeletal size for the tank and the average age of the sample. 


\section{A.2 2010 Coral Tissue Lipid Data}

\begin{tabular}{|c|c|c|c|c|c|}
\hline $\begin{array}{c}\text { Tank } \\
\text { Treatment }\end{array}$ & Sample ID & $\begin{array}{l}\text { Average Age } \\
\text { (days) }\end{array}$ & $\begin{array}{c}\text { Total Lipid } \\
(\mu \mathrm{g})\end{array}$ & $\begin{array}{c}\text { AN Lipid } \\
\left(\mu \mathbf{g ~ m m}^{-2} \text { spat }^{-1}\right)\end{array}$ & $\begin{array}{c}\text { AAN Lipid } \\
\left(\mu \mathbf{g ~ m m}^{-2} \text { day }^{-1} \text { spat }^{-1}\right)\end{array}$ \\
\hline 1 & LIP 59 & 21 & 92 & 6.29 & 0.30 \\
\hline $1670 \mathrm{ppm} \mathrm{CO}_{2}$ & LIP 60 & 21 & 88 & 6.05 & 0.29 \\
\hline \multirow[t]{2}{*}{ Unfed } & LIP 61 & 20 & 118 & 8.11 & 0.41 \\
\hline & LIP 96 & 21.3 & 145 & 9.96 & 0.47 \\
\hline Tank 1 Average & & & 111 & 7.60 & 0.37 \\
\hline 2 & LIP 74 & 22 & 416 & 12.26 & 0.56 \\
\hline $420 \mathrm{ppm} \mathrm{CO}_{2}$ & LIP76 & 21 & 389 & 11.45 & 0.55 \\
\hline Fed & LIP 98 & 21.4 & 392 & 11.54 & 0.54 \\
\hline Tank 2 Average & & & 399 & 11.75 & 0.55 \\
\hline 3 & LIP 62 & 21 & 178 & 10.95 & 0.52 \\
\hline 420 ppm $\mathrm{CO}_{2}$ & LIP 64 & 20 & 151 & 9.32 & 0.47 \\
\hline Unfed & LIP 95 & 21 & 159 & 9.78 & 0.47 \\
\hline Tank 3 Average & & & 162 & 10.02 & 0.48 \\
\hline 4 & LIP 78 & 22 & 138 & 9.94 & 0.45 \\
\hline $1670 \mathrm{ppm} \mathrm{CO}_{2}$ & LIP 79 & 21 & 243 & 17.51 & 0.83 \\
\hline Unfed & LIP 77 & 22 & 115 & 8.29 & 0.38 \\
\hline Tank 4 Average & & & 165 & 11.91 & 0.55 \\
\hline 5 & LIP 80 & 21.7 & 420 & 13.17 & 0.61 \\
\hline \multicolumn{6}{|l|}{$1670 \mathrm{ppm} \mathrm{CO} 2$} \\
\hline Tank 5 Average & & & 420 & 13.17 & 0.61 \\
\hline 6 & LIP 91 & 20.5 & 137 & 9.38 & 0.46 \\
\hline $420 \mathrm{ppm} \mathrm{CO}_{2}$ & LIP 92 & 21.5 & 154 & 10.54 & 0.49 \\
\hline \multirow[t]{2}{*}{ Unfed } & LIP 65 & 21 & 176 & 12.05 & 0.57 \\
\hline & LIP 66 & 20 & 178 & 12.19 & 0.61 \\
\hline Tank 6 Average & & & 161 & 11.04 & 0.53 \\
\hline 7 & LIP 72 & 21 & 152 & 10.29 & 0.49 \\
\hline $420 \mathrm{ppm} \mathrm{CO}_{2}$ & LIP 73 & 20.3 & 203 & 13.78 & 0.68 \\
\hline \multirow[t]{2}{*}{ Unfed } & LIP 93 & 21 & 105 & 7.13 & 0.34 \\
\hline & LIP 94 & 22 & 133 & 9.03 & 0.41 \\
\hline Tank 7 Average & & & 148 & 10.06 & 0.48 \\
\hline 8 & LIP 84 & 21 & 263 & 20.48 & 0.98 \\
\hline $\begin{array}{c}1670 \mathrm{ppm} \mathrm{CO}_{2} \\
\text { Unfed }\end{array}$ & LIP 85 & 21 & 150 & 11.70 & 0.56 \\
\hline Tank 8 Average & & & 206 & 16.09 & 0.77 \\
\hline 9 & LIP 86 & 22 & 426 & 12.64 & 0.57 \\
\hline $1670 \mathrm{ppm} \mathrm{CO}_{2}$ & LIP 87 & 21 & 377 & 11.19 & 0.53 \\
\hline Fed & LIP 100 & 21.1 & 295 & 8.74 & 0.41 \\
\hline Tank 9 Average & & & 366 & 10.86 & 0.51 \\
\hline
\end{tabular}


2010 lipid data, continued

\begin{tabular}{|c|c|c|c|c|c|}
\hline $\begin{array}{c}\text { Tank } \\
\text { Treatment }\end{array}$ & Sample ID & $\begin{array}{l}\text { Average Age } \\
\text { (days) }\end{array}$ & $\begin{array}{c}\text { Total Lipid } \\
(\mu \mathrm{g})\end{array}$ & $\begin{array}{c}\text { AN Lipid } \\
\left(\mu \mathrm{g} \mathrm{mm}^{-2} \text { spat }^{-1}\right)\end{array}$ & $\begin{array}{c}\text { AAN Lipid } \\
\left(\mu \mathbf{g ~ m m}^{-2} \text { day }^{-1} \text { spat }^{-1}\right)\end{array}$ \\
\hline 10 & LIP 99 & 21.9 & 466 & 13.15 & 0.60 \\
\hline $\begin{array}{c}420 \mathrm{ppm} \mathrm{CO}_{2} \\
\text { Fed }\end{array}$ & LIP 88 & 22 & 450 & 12.70 & 0.58 \\
\hline Tank 10 Average & & & 458 & 12.92 & 0.59 \\
\hline 11 & LIP 68 & 20 & 499 & 13.15 & 0.66 \\
\hline $\begin{array}{c}420 \mathrm{ppm} \mathrm{CO}_{2} \\
\text { Fed }\end{array}$ & LIP 97 & 22 & 478 & 12.61 & 0.57 \\
\hline Tank 11 Average & & & 488 & 12.88 & 0.62 \\
\hline 12 & LIP 69 & 21 & 336 & 9.68 & 0.46 \\
\hline $1670 \mathrm{ppm} \mathrm{CO}_{2}$ & LIP 70 & 21 & 413 & 11.90 & 0.57 \\
\hline Fed & LIP 71 & 20 & 335 & 9.67 & 0.48 \\
\hline Tank 12 Average & & & 361 & 10.42 & 0.50 \\
\hline
\end{tabular}

Table A.2: Total lipid weight, Area-Normalized (AN) lipid weight and Age- and AreaNormalized (AAN) lipid weight. AN Lipid is the total mass of lipid measured for a given sample divided by the number of specimens in that sample (10) and the circular area defined by the average skeletal size (i.e., septa diameter) for the tank (derived from Appendix A.1). AAN Lipid is AN Lipid divided by the average age of the sample. 


\section{A.3 2010 Symbiont Density Data}

\begin{tabular}{|c|c|c|c|c|c|}
\hline $\begin{array}{c}\text { Tank } \\
\text { Treatment }\end{array}$ & Sample ID & $\begin{array}{c}\text { Average Age } \\
(\text { days })\end{array}$ & $\begin{array}{c}\text { Symbionts } \\
\text { (cells) }\end{array}$ & $\begin{array}{l}\text { AN Symbionts } \\
\left(\times 10^{3} \text { cells }\right. \\
\left.\text { mm }^{-2} \text { spat }^{-1}\right)\end{array}$ & $\begin{array}{c}\text { AAN Symbionts } \\
\left(\times 10^{3} \text { cells }\right. \\
\left.\text { mm }^{-2} \text { day }^{-1} \text { spat }^{-1}\right)\end{array}$ \\
\hline 1 & ZOOX 11 & 21.0 & 71.5 & 24.54 & 1.17 \\
\hline $1670 \mathrm{ppm} \mathrm{CO}_{2}$ & ZOOX 12 & 20.0 & 42.5 & 14.58 & 0.73 \\
\hline Unfed & ZOOX 13 & 20.0 & 45.5 & 15.61 & 0.78 \\
\hline Tank 1 Average & & & 53.1 & 18.25 & 0.89 \\
\hline 2 & ZOOX 25 & 21 & 128.5 & 18.93 & 0.90 \\
\hline $420 \mathrm{ppm} \mathrm{CO}_{2}$ & ZOOX 26 & 20 & 115.1 & 16.97 & 0.85 \\
\hline \multirow[t]{2}{*}{ Fed } & ZOOX 27 & 20 & 87.9 & 12.96 & 0.65 \\
\hline & ZOOX 47 & 21 & 167.8 & 24.72 & 1.18 \\
\hline Tank 2 Average & & & 124.8 & 18.39 & 0.89 \\
\hline 3 & ZOOX 14 & 21 & 48.0 & 14.80 & 0.70 \\
\hline $420 \mathrm{ppm} \mathrm{CO}_{2}$ & ZOOX 15 & 20 & 33.3 & 10.27 & 0.51 \\
\hline \multirow[t]{2}{*}{ Unfed } & ZOOX 44 & 21 & 27.4 & 8.46 & 0.40 \\
\hline & ZOOX 45 & 21 & 25.2 & 7.78 & 0.37 \\
\hline Tank 3 Average & & & 33.5 & 10.33 & 0.50 \\
\hline 4 & ZOOX 28 & 21 & 79.6 & 28.69 & 1.37 \\
\hline $1670 \mathrm{ppm} \mathrm{CO}_{2}$ & ZOOX 29 & 20 & 62.3 & 22.45 & 1.12 \\
\hline Unfed & ZOOX 30 & 20 & 34.0 & 12.27 & 0.61 \\
\hline Tank 4 Average & & & 58.7 & 21.14 & 1.03 \\
\hline 5 & ZOOX 31 & 21.0 & 110.4 & 17.32 & 0.82 \\
\hline $1670 \mathrm{ppm} \mathrm{CO}_{2}$ & ZOOX 32 & 21.0 & 106.4 & 16.69 & 0.79 \\
\hline Fed & ZOOX 36 & 21.4 & 168.2 & 26.40 & 1.23 \\
\hline Tank 5 Average & & & 128.3 & 20.14 & 0.95 \\
\hline 6 & ZOOX 16 & 21 & 51.5 & 17.65 & 0.84 \\
\hline $420 \mathrm{ppm} \mathrm{CO}_{2}$ & ZOOX 17 & 21 & 27.1 & 9.29 & 0.44 \\
\hline \multirow[t]{2}{*}{ Unfed } & ZOOX 40b & 20 & 26.5 & 9.09 & 0.45 \\
\hline & ZOOX 41 & 21 & 56.3 & 19.29 & 0.92 \\
\hline Tank 6 Average & & & 40.4 & 13.83 & 0.66 \\
\hline 7 & ZOOX 23 & 21 & 72.3 & 24.53 & 1.17 \\
\hline $420 \mathrm{ppm} \mathrm{CO}_{2}$ & ZOOX 24 & 20 & 46.2 & 15.67 & 0.78 \\
\hline \multirow[t]{2}{*}{ Unfed } & ZOOX 42 & 20 & 53.6 & 18.19 & 0.91 \\
\hline & ZOOX 43 & 21 & 47.3 & 16.07 & 0.77 \\
\hline Tank 7 Average & & & 54.8 & 18.61 & 0.91 \\
\hline 8 & ZOOX 33 & 22 & 66.8 & 26.08 & 1.19 \\
\hline $1670 \mathrm{ppm} \mathrm{CO}_{2}$ & ZOOX 34 & 21 & 93.4 & 36.43 & 1.73 \\
\hline Unfed & ZOOX 35 & 21 & 78.3 & 30.55 & 1.45 \\
\hline
\end{tabular}


2010 symbiont data, continued

\begin{tabular}{|c|c|c|c|c|c|}
\hline $\begin{array}{c}\text { Tank } \\
\text { Treatment }\end{array}$ & Sample ID & $\begin{array}{c}\text { Average Age } \\
(\text { days })\end{array}$ & $\begin{array}{c}\text { Symbionts } \\
\text { (cells) }\end{array}$ & $\begin{array}{c}\text { AN Symbionts } \\
\left(\times 10^{3} \text { cells }\right. \\
\left.\text { mm }^{-2} \text { spat }^{-1}\right)\end{array}$ & $\begin{array}{c}\text { AAN Symbionts } \\
\left(\mathrm{x}^{1} 0^{3} \text { cells }\right. \\
\left.\mathrm{mm}^{-2} \text { day }^{-1} \text { spat }^{-1}\right)\end{array}$ \\
\hline Tank 8 Average & & & 79.5 & 31.02 & 1.46 \\
\hline 9 & ZOOX 37 & 21 & 153.3 & 22.75 & 1.08 \\
\hline \multicolumn{6}{|l|}{$1670 \mathrm{ppm} \mathrm{CO}_{2}$} \\
\hline \multicolumn{6}{|l|}{ Fed } \\
\hline Tank 9 Average & & & 153.3 & 22.75 & 1.08 \\
\hline 10 & ZOOX 38 & 21 & 173.1 & 24.45 & 1.16 \\
\hline $420 \mathrm{ppm} \mathrm{CO}_{2}$ & ZOOX 39 & 21 & 173.5 & 24.51 & 1.17 \\
\hline Fed & ZOOX 40a & 21 & 120.4 & 17.01 & 0.81 \\
\hline Tank 10 Average & & & 155.7 & 21.99 & 1.05 \\
\hline 11 & ZOOX 18 & 20 & 105.2 & 13.87 & 0.69 \\
\hline $420 \mathrm{ppm} \mathrm{CO}_{2}$ & ZOOX 19 & 20 & 97.6 & 12.87 & 0.64 \\
\hline Fed & ZOOX 46 & 20.8 & 66.6 & 8.79 & 0.42 \\
\hline Tank 11 Average & & & 89.8 & 11.84 & 0.59 \\
\hline 12 & ZOOX 20 & 21 & 99.8 & 14.40 & 0.69 \\
\hline $1670 \mathrm{ppm} \mathrm{CO}_{2}$ & ZOOX 21 & 20 & 95.5 & 13.78 & 0.69 \\
\hline Fed & ZOOX 22 & 20 & 78.2 & 11.28 & 0.56 \\
\hline Tank 12 Average & & & 91.2 & 13.15 & 0.65 \\
\hline
\end{tabular}

Table A.3: Symbiont count, Area-Normalized (AN) Symbiont density, and Area- and AgeNormalized (AAN) Symbiont density for the $2010 \mathrm{CO}_{2}$ x Feeding experiment. Symbionts is the average number of zooxanthellae cells counted in the hemacytometer grid, AN Symbionts is the total symbiont density for the sample divided by the number of specimens in that sample (5) and the circular area defined by the average skeletal size (i.e., septa diameter) for the tank (derived from Appendix A.1), and AAN Symbionts is AN Symbionts divided by the average age of the sample. 


\section{A.4 2010 Pigment Data}

\begin{tabular}{|c|c|c|c|c|c|}
\hline $\begin{array}{c}\text { Tank } \\
\text { Treatment }\end{array}$ & Sample ID & $\begin{array}{c}\text { Average Age } \\
\text { (days) }\end{array}$ & $\begin{array}{l}\text { Pigment } \\
\quad(\text { ng } \text { chl } a)\end{array}$ & $\begin{array}{l}\text { AN Pigment } \\
(\text { ng } \text { chl } a \\
\left.\text { mm }^{-2} \text { spat }^{-1}\right)\end{array}$ & $\begin{array}{c}\text { AANPigment } \\
(\mathrm{ng} \text { chl } a \\
\left.\mathrm{mm}^{-2} \mathrm{day}^{-1} \text { spat }^{-1}\right)\end{array}$ \\
\hline 1 & RNA 22 & 20.0 & 114.71 & 15.76 & 0.79 \\
\hline $1670 \mathrm{ppm} \mathrm{CO}_{2}$ & RNA 23 & 21.6 & 210.38 & 28.90 & 1.34 \\
\hline Unfed & RNA 24 & 22.0 & 214.20 & 29.43 & 1.34 \\
\hline Tank 1 Average & & & 179.76 & 24.70 & 1.15 \\
\hline 3 & RNA 19 & 22.0 & 208.26 & 25.70 & 1.17 \\
\hline $\begin{array}{c}420 \mathrm{ppm} \mathrm{CO}_{2} \\
\text { Unfed }\end{array}$ & RNA 20 & 22.0 & 268.78 & 33.17 & 1.51 \\
\hline Tank 3 Average & & & 238.52 & 29.44 & 1.34 \\
\hline 4 & RNA 5 & 22.0 & 221.48 & 31.92 & 1.45 \\
\hline $\begin{array}{c}1670 \mathrm{ppm} \mathrm{CO}_{2} \\
\text { Unfed }\end{array}$ & RNA 6 & 20.0 & 151.63 & 21.85 & 1.09 \\
\hline Tank 4 Average & & & 186.56 & 26.89 & 1.27 \\
\hline 6 & RNA 11 & 22.0 & 117.28 & 16.06 & 0.73 \\
\hline $420 \mathrm{ppm} \mathrm{CO}_{2}$ & RNA 12 & 22.0 & 162.57 & 22.26 & 1.01 \\
\hline Unfed & RNA 13 & 22.0 & 431.09 & 59.03 & 2.68 \\
\hline Tank 6 Average & & & 236.98 & 32.45 & 1.48 \\
\hline $\begin{array}{c}7 \\
420 \mathrm{ppm} \mathrm{\textrm {CO } _ { 2 }} \\
\text { Unfed }\end{array}$ & RNA 14 & 21.8 & 218.06 & 29.61 & 1.36 \\
\hline Tank 7 Average & & & 218.06 & 29.61 & 1.36 \\
\hline 8 & RNA 8 & 21.0 & 86.51 & 13.50 & 0.64 \\
\hline $1670 \mathrm{ppm} \mathrm{CO}_{2}$ & RNA 9 & 21.0 & 106.81 & 16.67 & 0.79 \\
\hline Unfed & RNA 10 & 20.0 & 109.20 & 17.04 & 0.85 \\
\hline Tank 8 Average & & & 100.84 & 15.74 & 0.76 \\
\hline
\end{tabular}

Table A.4: Pigment mass, Area-Normalized (AN) Pigment density, and Area- and AgeNormalized (AAN) Pigment density for the $2010 \mathrm{CO}_{2} \times$ Feeding experiment. Pigment is the total mass chl $a$ in the sample, AN Pigment is the total pigment mass for the sample divided by the number of specimens in that sample (5) and the circular area defined by the average skeletal size (i.e., septa diameter) for the tank (derived from Appendix A.1), and AAN Pigment is AN Pigment divided by the average age of the sample. 


\section{A.5 2010 Statistical Analyses}

\section{A.5.1}

\begin{tabular}{l|cccc}
\hline \hline Source & df & MS & $\boldsymbol{F}$ & $\boldsymbol{p}$ \\
\hline Feeding & 1 & 2.108 & 126.876 & $<0.001$ \\
$\mathrm{CO}_{2}$ & 1 & 0.01 & 0.579 & 0.469 \\
$\mathrm{CO}_{2}$ x Feeding & 1 & 0.000 & 0.004 & 0.949 \\
Error & 8 & 0.017 & & \\
\hline \hline
\end{tabular}

Results from two-way ANOVA for skeletal development (\% spat). Data were arc sin square root transformed in order to homogenize variances prior to analyses. Table reports df (degrees of freedom), and MS (mean sum of squares), F (F statistic) and p (significance level) for indicated sources.

\section{A.5.2}

\begin{tabular}{l|cccc}
\hline \hline Source & df & $\lambda$ & $\boldsymbol{F}$ & $\boldsymbol{p}$ \\
\hline Feeding & 2,7 & 0.010 & 337.628 & $<0.001$ \\
$\mathrm{CO}_{2}$ & 2,7 & 0.064 & 50.924 & $<0.001$ \\
$\mathrm{CO}_{2} \times$ Feeding & 2,7 & 0.630 & 2.055 & 0.199 \\
Tank $\left(\mathrm{CO}_{2} \times\right.$ Feeding $)$ & 16,558 & 0.953 & 0.858 & 0.619 \\
\hline \hline
\end{tabular}

Results from two-way, nested MANOVA of mean corallite diameter and weight. Dependent variables were weight and diameter, tank effect was nested within $\mathrm{CO}_{2}$ and feeding interaction. Prior to analysis, corallite weight was natural $\log$ transformed and diameter was square root transformed. Table reports df (degrees of freedom), $\lambda$ (Wilk's lambda), $F$ (F statistic) and $p$ (significance level) for indicated sources. 
A.5.3

\begin{tabular}{l|ccccccc}
\hline \hline & \multicolumn{4}{|c}{ Weight } & \multicolumn{3}{c}{ Diameter } \\
Source & df & MS & $\boldsymbol{F}$ & $\boldsymbol{p}$ & MS & $\boldsymbol{F}$ & $\boldsymbol{p}$ \\
\hline Feeding & 1 & 10.002 & 136.696 & $<0.001$ & 3893.983 & 589.073 & $<0.001$ \\
$\mathrm{CO}_{2}$ & 1 & 4.766 & 65.135 & $<0.001$ & 35.606 & 5.386 & 0.049 \\
$\mathrm{CO}_{2}$ x Feeding & 1 & 0.097 & 1.326 & 0.283 & 0.144 & 0.022 & 0.886 \\
Tank $\left(\mathrm{CO}_{2}\right.$ x Feeding $)$ & 8 & 0.073 & 0.688 & 0.702 & 6.610 & 0.741 & 0.655 \\
Error & 280 & 0.107 & & & 8.923 & & \\
\hline \hline
\end{tabular}

Univariate results on each dependent variable used in the MANOVA F-tests were declared significant at alpha $=0.0062$ determined for a Bonferroni correction on a total of eight F-tests. Table reports df (degrees of freedom), $\lambda$ (Wilk's lambda), $F$ (F statistic) and $p$ (significance level) for indicated sources.

\section{A.5.4}

\begin{tabular}{l|ccccccc}
\hline \hline & \multicolumn{4}{|c}{ Tissue Lipid Conent } & \multicolumn{3}{c}{ Symbiont Density } \\
Source & df & MS & $\boldsymbol{F}$ & $\boldsymbol{p}$ & MS & $\boldsymbol{F}$ & $\boldsymbol{p}$ \\
\hline Feeding & 1 & $2.817 \mathrm{E}-03$ & 2.279 & 0.170 & $1.201 \mathrm{E}+07$ & 0.136 & 0.722 \\
$\mathrm{CO}_{2}$ & 1 & $1.150 \mathrm{E}-04$ & 0.093 & 0.768 & $2.164 \mathrm{E}+08$ & 2.456 & 0.156 \\
$\mathrm{CO}_{2}$ x Feeding & 1 & $1.170 \mathrm{E}-04$ & 0.095 & 0.766 & $1.670 \mathrm{E}+08$ & 1.895 & 0.206 \\
Tank $\left(\mathrm{CO}_{2}\right.$ x Feeding $)$ & 8 & $1.236 \mathrm{E}-03$ & 2.870 & 0.022 & $8.811 \mathrm{E}+07$ & 4.158 & 0.003 \\
Error & 24 & $4.310 \mathrm{E}-04$ & & & $2.119 \mathrm{E}+07$ & & \\
\hline \hline
\end{tabular}

Results from two-way, nested ANOVAs for mean, area-normalized tissue lipid content and symbiont density. Lipid data were $-1 / \mathrm{x}$ transformed to homogenize the variances prior to analysis. Table reports df (degrees of freedom), MS (mean sum of squares), $F$ (F statistic) and $p$ (significance level) for indicated sources. 
A.5.5

\begin{tabular}{|c|c|c|c|c|c|}
\hline Treatment & $\begin{array}{c}\text { Skeletal } \\
\text { Development }\end{array}$ & $\begin{array}{c}\text { Skeletal Diameter } \\
\text { ANOVA (MANOVA) }\end{array}$ & $\begin{array}{c}\text { Skeletal Weight } \\
\text { ANOVA (MANOVA) }\end{array}$ & $\begin{array}{c}\text { Symbiont } \\
\text { Density }\end{array}$ & $\begin{array}{c}\text { Lipid } \\
\text { Weight }\end{array}$ \\
\hline $\begin{array}{c}\text { Ambient } \mathrm{CO}_{2} \\
\text { Fed }\end{array}$ & $11,12,45$ & $10,10,44(10,10,41)$ & $11,11,42(10,10,41)$ & $4,3,3$ & $2,3,3$ \\
\hline $\begin{array}{c}\text { Ambient } \mathrm{CO}_{2} \\
\text { Unfed }\end{array}$ & $39,36,54$ & $42,34,60(39,26,51)$ & $41,27,55(39,26,51)$ & $4,4,4$ & $4,4,3$ \\
\hline $\begin{array}{c}\text { High } \mathrm{CO}_{2} \\
\text { Fed }\end{array}$ & $14,17,17$ & $11,13,12(11,10,11)$ & $12,11,11(11,10,11)$ & $2,2,3$ & $3,3,2$ \\
\hline $\begin{array}{l}\text { High } \mathrm{CO}_{2} \\
\text { Unfed }\end{array}$ & $33,35,44$ & $30,31,39(25,25,35)$ & $26,27,37(25,25,35)$ & $3,3,3$ & $2,3,4$ \\
\hline
\end{tabular}

Sample size (n) for each statistical assessment reported in order of tank replicate $(1,2,3)$ for a given condition 


\section{Appendix B}

\section{Data for Chapter 4}

\section{B.1 2011 Skeletal Size and Weight Data}

\begin{tabular}{|c|c|c|c|c|c|c|}
\hline $\begin{array}{c}\text { Tank } \\
\text { Treatment }\end{array}$ & Tile ID & $\begin{array}{c}\text { Tile Age } \\
\text { (days) }\end{array}$ & Coralite ID & $\begin{array}{l}\text { Size } \\
(\mu \mathrm{m})\end{array}$ & $\begin{array}{c}\text { Weight } \\
(\mu \mathrm{g})\end{array}$ & $\begin{array}{c}\text { ASN Weight } \\
\left(\mu \mathbf{g ~ m m}^{-1} \text { day }^{-1}\right)\end{array}$ \\
\hline 1 & 1 & 21 & $\mathrm{~A}$ & 1008 & & \\
\hline $1670 \mathrm{ppm} \mathrm{CO}_{2}$ & & & $\mathrm{~B}$ & 1264 & 219 & 8.46 \\
\hline \multirow[t]{9}{*}{ Unfed } & & & $\mathrm{C}$ & 1105 & 210 & 8.11 \\
\hline & & & $\mathrm{D}$ & 1308 & 233 & 9.00 \\
\hline & & & $\mathrm{F}$ & 1185 & 251 & 9.69 \\
\hline & & & $\mathrm{E}$ & 1197 & 176 & 6.80 \\
\hline & & & $\mathrm{H}$ & 1430 & 300 & 11.59 \\
\hline & & & $\mathrm{J}$ & 1287 & 217 & 8.38 \\
\hline & & & $\mathrm{L}$ & 1193 & & \\
\hline & & & M & 1303 & & \\
\hline & 2 & 21 & $\mathrm{~B}$ & 1283 & & \\
\hline Tank 1 Average & & & & 1233 & 229 & 8.86 \\
\hline 2 & 3 & 24 & $\mathrm{~B}$ & 1840 & 461 & 10.54 \\
\hline $420 \mathrm{ppm} \mathrm{CO}_{2}$ & & & $\mathrm{E}$ & 1414 & 316 & 7.23 \\
\hline \multirow[t]{16}{*}{ Fed } & & & G & 2147 & 739 & 16.90 \\
\hline & & & I & 1720 & 348 & 7.96 \\
\hline & & & $\mathrm{K}$ & 1466 & 304 & 6.95 \\
\hline & 10 & 23 & $\mathrm{~A}$ & 2074 & & \\
\hline & & & $\mathrm{C}$ & 1277 & 316 & 7.54 \\
\hline & & & $\mathrm{H}$ & 1760 & 434 & 10.36 \\
\hline & & & I & 1229 & 248 & 5.92 \\
\hline & & & $\mathrm{J}$ & 1970 & 588 & 14.03 \\
\hline & 15 & 23 & $\mathrm{~F}$ & 1285 & 256 & 6.11 \\
\hline & & & G & 2125 & 574 & 13.70 \\
\hline & & & $\mathrm{P}$ & 2114 & 589 & 14.06 \\
\hline & & & $\mathrm{Q}$ & 2236 & 603 & 14.39 \\
\hline & & & $\mathrm{T}$ & 1640 & 443 & 10.57 \\
\hline & 16 & 23 & $\mathrm{~A}$ & 2255 & & \\
\hline & & & B & 2472 & 600 & 14.32 \\
\hline & & & $\mathrm{D}$ & 1769 & 390 & 9.31 \\
\hline Tank 2 Average & & & & 1822 & 451 & 10.62 \\
\hline 3 & 1 & 21 & $\mathrm{~B}$ & 1483 & 350 & 12.25 \\
\hline $1200 \mathrm{ppm} \mathrm{CO}_{2}$ & & & $\mathrm{C}$ & 1269 & 258 & 9.03 \\
\hline \multirow[t]{2}{*}{ Unfed } & & & $\mathrm{J}$ & 1350 & 340 & 11.90 \\
\hline & 2 & 21 & $\mathrm{~B}$ & 1264 & 129 & 4.52 \\
\hline
\end{tabular}


2011 skeletal size and weight data, continued

\begin{tabular}{|c|c|c|c|c|c|c|}
\hline $\begin{array}{c}\text { Tank } \\
\text { Treatment }\end{array}$ & Tile ID & $\begin{array}{l}\text { Tile Age } \\
\text { (days) }\end{array}$ & Coralite ID & $\begin{array}{l}\text { Size } \\
(\mu \mathrm{m})\end{array}$ & $\begin{array}{c}\text { Weight } \\
(\mu \mathrm{g})\end{array}$ & $\begin{array}{c}\text { ASN Weight } \\
\left(\mu \mathbf{g ~ m m}^{-1} \text { day }^{-1}\right)\end{array}$ \\
\hline & & & $\mathrm{E}$ & 1246 & 227 & 7.95 \\
\hline & 4 & 24 & $\mathrm{~B}$ & 1436 & 368 & 11.27 \\
\hline & 5 & 24 & $\mathrm{~A}$ & 1537 & 452 & 13.85 \\
\hline & 9 & 23 & $\mathrm{~A}$ & 1428 & 307 & 9.81 \\
\hline & & & B & 1351 & & \\
\hline & & & $\mathrm{C}$ & 1457 & 336 & 10.74 \\
\hline & 19 & 22 & $\mathrm{C}$ & 1138 & 187 & 6.25 \\
\hline Tank 3 Average & & & & 1360 & 295 & 9.76 \\
\hline 4 & 2 & 21 & $\mathrm{~A}$ & 1506 & 270 & 10.53 \\
\hline $2700 \mathrm{ppm} \mathrm{CO}_{2}$ & 13 & 23 & $\mathrm{C}$ & 1312 & 212 & 7.55 \\
\hline \multirow[t]{14}{*}{ Unfed } & & & $\mathrm{D}$ & 1331 & 242 & 8.62 \\
\hline & 17 & 22 & A & 1393 & 257 & 9.57 \\
\hline & & & B & 913 & 117 & 4.36 \\
\hline & & & $\mathrm{C}$ & 1268 & 162 & 6.03 \\
\hline & & & $\mathrm{D}$ & 1175 & 261 & 9.72 \\
\hline & & & $\mathrm{E}$ & 1175 & 170 & 6.33 \\
\hline & & & $\mathrm{F}$ & 1054 & & \\
\hline & & & G & 1017 & 131 & 4.88 \\
\hline & & & $\mathrm{H}$ & 1078 & 138 & 5.14 \\
\hline & & & I & 1296 & 213 & 7.93 \\
\hline & & & $\mathrm{J}$ & 1250 & 176 & 6.55 \\
\hline & & & K & 1319 & 237 & 8.83 \\
\hline & & & $\mathrm{L}$ & 1325 & 194 & 7.22 \\
\hline & & & M & 1117 & 177 & 6.59 \\
\hline Tank 4 Average & & & & 1221 & 197 & 7.32 \\
\hline 5 & 1 & 21 & $\mathrm{~A}$ & 1831 & 473 & 13.40 \\
\hline $1200 \mathrm{ppm} \mathrm{CO}_{2}$ & 2 & 21 & $\mathrm{~A}$ & 1255 & 286 & 8.10 \\
\hline \multirow[t]{10}{*}{ Fed } & 6 & 24 & $\mathrm{~B}$ & 1527 & 413 & 10.24 \\
\hline & & & $\mathrm{C}$ & 1505 & 414 & 10.26 \\
\hline & & & $\mathrm{D}$ & 1792 & & \\
\hline & & & $\mathrm{E}$ & 1801 & 518 & 12.84 \\
\hline & 15 & 23 & $\mathrm{H}$ & 1914 & 432 & 11.17 \\
\hline & & & M & 1837 & 434 & 11.23 \\
\hline & & & $\mathrm{L}$ & 1407 & 289 & 7.48 \\
\hline & & & $\mathrm{N}$ & 2020 & 615 & 15.91 \\
\hline & & & $\mathrm{O}$ & 1628 & 331 & 8.56 \\
\hline & & & $\mathrm{C}$ & 1655 & 541 & 13.99 \\
\hline Tank 5 Average & & & & 1681 & 431 & 11.20 \\
\hline 6 & 4 & 26 & $\mathrm{~A}$ & 1155 & 185 & 5.97 \\
\hline $1670 \mathrm{ppm} \mathrm{CO} 2$ & & & B & 1198 & 203 & 6.55 \\
\hline
\end{tabular}


2011 skeletal size and weight data, continued

\begin{tabular}{|c|c|c|c|c|c|c|}
\hline $\begin{array}{c}\text { Tank } \\
\text { Treatment }\end{array}$ & Tile ID & $\begin{array}{c}\text { Tile Age } \\
\text { (days) }\end{array}$ & Coralite ID & $\begin{array}{l}\text { Size } \\
(\mu \mathrm{m})\end{array}$ & $\begin{array}{c}\text { Weight } \\
(\mu \mathrm{g})\end{array}$ & $\begin{array}{c}\text { ASN Weight } \\
\left(\mu \mathrm{g} \mathrm{mm}^{-1} \text { day }^{-1}\right)\end{array}$ \\
\hline \multirow[t]{19}{*}{ Unfed } & & & $\mathrm{C}$ & 1151 & 211 & 6.81 \\
\hline & & & $\mathrm{D}$ & 1211 & 211 & 6.81 \\
\hline & & & $\mathrm{E}$ & 1247 & 190 & 6.13 \\
\hline & & & $\mathrm{F}$ & 1152 & 164 & 5.29 \\
\hline & & & $\mathrm{G}$ & 1164 & 157 & 5.07 \\
\hline & & & $\mathrm{H}$ & 1471 & & \\
\hline & & & I & 1194 & & \\
\hline & & & $\mathrm{J}$ & 1167 & 177 & 5.71 \\
\hline & & & $\mathrm{K}$ & 868 & & \\
\hline & & & $\mathrm{L}$ & 1149 & & \\
\hline & & & M & 1100 & 198 & 6.39 \\
\hline & & & $\mathrm{N}$ & 1171 & & \\
\hline & & & $\mathrm{O}$ & 1205 & & \\
\hline & & & $\mathrm{P}$ & 1242 & & \\
\hline & & & $\mathrm{Q}$ & 1068 & & \\
\hline & & & $\mathrm{R}$ & 1041 & & \\
\hline & 5 & 24 & $\mathrm{~A}$ & 1441 & 250 & 8.74 \\
\hline & & & B & 1190 & 156 & 5.45 \\
\hline & & & $\mathrm{C}$ & 1450 & 216 & 7.55 \\
\hline Tank 6 Average & & & & 1192 & 193 & 6.37 \\
\hline 7 & 2 & 21 & $\mathrm{E}$ & 1546 & 249 & 6.78 \\
\hline $1200 \mathrm{ppm} \mathrm{CO} 2$ & & & I & 1274 & 251 & 6.84 \\
\hline \multirow[t]{9}{*}{ Fed } & & & $\mathrm{J}$ & 1849 & 513 & 13.98 \\
\hline & & & K & 1767 & & \\
\hline & 3 & 21 & $\mathrm{H}$ & 1231 & & \\
\hline & & & $\mathrm{D}$ & 1758 & 285 & 7.76 \\
\hline & 6 & 25 & $\mathrm{H}$ & 1764 & 474 & 10.85 \\
\hline & & & I & 2297 & 744 & 17.03 \\
\hline & & & $\mathrm{J}$ & 2212 & 633 & 14.49 \\
\hline & & & G & 1419 & 260 & 5.95 \\
\hline & 8 & 25 & $\mathrm{~B}$ & 2110 & 525 & 12.01 \\
\hline Tank 7 Average & & & & 1748 & 437 & 10.63 \\
\hline 8 & 11 & 25 & $\mathrm{~A}$ & 1227 & 188 & 5.88 \\
\hline $2700 \mathrm{ppm} \mathrm{CO}_{2}$ & & & B & 1476 & 264 & 8.25 \\
\hline \multirow[t]{6}{*}{ Fed } & 13 & 24 & $\mathrm{Q}$ & 1453 & 252 & 8.21 \\
\hline & & & $\mathrm{R}$ & 1104 & 169 & 5.50 \\
\hline & & & $\mathrm{S}$ & 1270 & & \\
\hline & & & $\mathrm{T}$ & 1446 & 241 & 7.85 \\
\hline & & & $\mathrm{U}$ & 1242 & 144 & 4.69 \\
\hline & & & V & 1296 & 196 & 6.38 \\
\hline
\end{tabular}


2011 skeletal size and weight data, continued

\begin{tabular}{|c|c|c|c|c|c|c|}
\hline $\begin{array}{c}\text { Tank } \\
\text { Treatment }\end{array}$ & Tile ID & $\begin{array}{c}\text { Tile Age } \\
\text { (days) }\end{array}$ & Coralite ID & $\begin{array}{l}\text { Size } \\
(\mu \mathrm{m})\end{array}$ & $\begin{array}{c}\text { Weight } \\
(\mu \mathrm{g})\end{array}$ & $\begin{array}{c}\text { ASN Weight } \\
\left(\mu \mathrm{g} \mathrm{mm}^{-1} \text { day }^{-1}\right)\end{array}$ \\
\hline & 17 & 24 & $\mathrm{~A}$ & 1216 & 217 & 7.07 \\
\hline & & & B & 1201 & 192 & 6.25 \\
\hline & & & $\mathrm{C}$ & 1019 & 115 & 3.75 \\
\hline & & & $\mathrm{D}$ & 1107 & 126 & 4.10 \\
\hline & & & $\mathrm{E}$ & 1679 & 365 & 11.89 \\
\hline & & & $\mathrm{F}$ & 1359 & 237 & 7.72 \\
\hline & & & G & 1223 & 181 & 5.89 \\
\hline & & & $\mathrm{H}$ & 1385 & 260 & 8.47 \\
\hline & & & I & 1331 & 203 & 6.61 \\
\hline & & & $\mathrm{J}$ & 1252 & 196 & 6.38 \\
\hline & & & $\mathrm{K}$ & 1292 & 177 & 5.76 \\
\hline & & & $\mathrm{L}$ & 1211 & 171 & 5.57 \\
\hline & & & M & 1234 & 205 & 6.68 \\
\hline & & & $\mathrm{N}$ & 1289 & 192 & 6.25 \\
\hline & & & $\mathrm{O}$ & 1408 & 223 & 7.26 \\
\hline & & & $\mathrm{P}$ & 1053 & 111 & 3.61 \\
\hline & & & $\mathrm{R}$ & 1306 & 239 & 7.78 \\
\hline & & & $\mathrm{Q}$ & 1374 & 179 & 5.83 \\
\hline & & & $\mathrm{S}$ & 1047 & 125 & 4.07 \\
\hline & & & $\mathrm{T}$ & 1460 & 289 & 9.41 \\
\hline & & & $\mathrm{U}$ & 1243 & 192 & 6.25 \\
\hline & & & $\mathrm{V}$ & 1203 & 196 & 6.38 \\
\hline & & & $\mathrm{W}$ & 1231 & 154 & 5.02 \\
\hline & & & $\mathrm{X}$ & 1348 & 194 & 6.32 \\
\hline & & & $\mathrm{Y}$ & 1095 & 158 & 5.15 \\
\hline & & & $\mathrm{Z}$ & 1632 & 247 & 8.04 \\
\hline & & & $\mathrm{AA}$ & 1456 & 262 & 8.53 \\
\hline & & & $\mathrm{AB}$ & 1479 & 260 & 8.47 \\
\hline & & & $\mathrm{AC}$ & 1151 & 157 & 5.11 \\
\hline & & & $\mathrm{AD}$ & 1330 & 192 & 6.25 \\
\hline & & & $\mathrm{AE}$ & 1089 & 112 & 3.65 \\
\hline & & & $\mathrm{AF}$ & 1095 & 161 & 5.24 \\
\hline & & & AG & 1259 & 215 & 7.00 \\
\hline & & & $\mathrm{AH}$ & 908 & 74 & 2.41 \\
\hline & & & AI & 1469 & & \\
\hline & & & AJ & 1076 & 157 & 5.11 \\
\hline & & & $\mathrm{AK}$ & 1561 & 317 & 10.32 \\
\hline & & & $\mathrm{AL}$ & 1273 & 213 & 6.94 \\
\hline Tank 8 Average & & & & 1279 & 198 & 6.44 \\
\hline 9 & 9 & 25 & $\mathrm{~F}$ & 1693 & & \\
\hline
\end{tabular}


2011 skeletal size and weight data, continued

\begin{tabular}{|c|c|c|c|c|c|c|}
\hline $\begin{array}{c}\text { Tank } \\
\text { Treatment }\end{array}$ & Tile ID & $\begin{array}{c}\text { Tile Age } \\
\text { (days) }\end{array}$ & Coralite ID & $\begin{array}{l}\text { Size } \\
(\mu \mathrm{m})\end{array}$ & $\begin{array}{c}\text { Weight } \\
(\mu \mathrm{g})\end{array}$ & $\begin{array}{c}\text { ASN Weight } \\
\left(\mu \mathrm{g} \mathrm{mm}^{-1} \text { day }^{-1}\right)\end{array}$ \\
\hline $420 \mathrm{ppm} \mathrm{CO}_{2}$ & & & $\mathrm{G}$ & 1581 & 508 & 10.27 \\
\hline \multirow[t]{8}{*}{ Fed } & 10 & 25 & $\mathrm{~J}$ & 1770 & 671 & 13.56 \\
\hline & & & $\mathrm{K}$ & 1488 & 471 & 9.52 \\
\hline & & & $\mathrm{L}$ & 1884 & 663 & 13.40 \\
\hline & 14 & 23 & $\mathrm{C}$ & 1432 & 390 & 8.57 \\
\hline & & & $\mathrm{D}$ & 2545 & 1022 & 22.46 \\
\hline & & & $\mathrm{E}$ & 2032 & 776 & 17.05 \\
\hline & 16 & 23 & $\mathrm{~A}$ & 2747 & 1062 & 23.34 \\
\hline & & & $\mathrm{B}$ & 2613 & 970 & 21.31 \\
\hline Tank 9 Average & & & & 1979 & 726 & 15.50 \\
\hline 10 & 12 & 25 & M & 1560 & 350 & 10.32 \\
\hline $1670 \mathrm{ppm} \mathrm{CO}_{2}$ & & & $\mathrm{~N}$ & 1175 & 185 & 5.46 \\
\hline \multirow[t]{10}{*}{ Unfed } & & & $\mathrm{O}$ & 1355 & 279 & 8.23 \\
\hline & 13 & 24 & $\mathrm{~A}$ & 1407 & 228 & 7.00 \\
\hline & & & K & 1307 & 228 & 7.00 \\
\hline & & & $\mathrm{L}$ & 1457 & 315 & 9.68 \\
\hline & & & M & 1251 & 200 & 6.14 \\
\hline & 14 & 24 & $\mathrm{~N}$ & 1298 & 236 & 7.25 \\
\hline & & & $\mathrm{O}$ & 1477 & 260 & 7.99 \\
\hline & 16 & 24 & $\mathrm{~F}$ & 1420 & 240 & 7.37 \\
\hline & & & G & 1196 & 186 & 5.71 \\
\hline & & & $\mathrm{H}$ & 1370 & 264 & 8.11 \\
\hline Tank 10 Average & & & & 1356 & 248 & 7.52 \\
\hline 11 & 5 & 26 & $\mathrm{~A}$ & 2129 & 342 & 6.79 \\
\hline $2700 \mathrm{ppm} \mathrm{CO}_{2}$ & & & G & 1916 & 500 & 9.92 \\
\hline \multirow[t]{13}{*}{ Fed } & 6 & 26 & $\mathrm{~A}$ & 1742 & 527 & 10.46 \\
\hline & & & $\mathrm{D}$ & 1889 & 309 & 6.13 \\
\hline & 7 & 26 & $\mathrm{H}$ & 1628 & 378 & 7.50 \\
\hline & & & $\mathrm{L}$ & 1564 & 259 & 5.14 \\
\hline & 8 & 26 & $\mathrm{~A}$ & 1759 & 394 & 7.82 \\
\hline & & & B & 1896 & & \\
\hline & & & $\mathrm{C}$ & 1941 & 566 & 11.23 \\
\hline & & & $\mathrm{D}$ & 1993 & & \\
\hline & & & $\mathrm{E}$ & 1837 & 339 & 6.73 \\
\hline & & & G & 1836 & 433 & 8.59 \\
\hline & 13 & 25 & $\mathrm{~A}$ & 2133 & 437 & 9.02 \\
\hline & 16 & 24 & $\mathrm{~A}$ & 2475 & & \\
\hline & & & $\mathrm{D}$ & 2331 & 425 & 9.14 \\
\hline Tank 11 Average & & & & 1938 & 409 & 8.21 \\
\hline 12 & 2 & 22 & $\mathrm{D}$ & 1450 & 380 & 12.37 \\
\hline
\end{tabular}


2011 skeletal size and weight data, continued

\begin{tabular}{|c|c|c|c|c|c|c|}
\hline $\begin{array}{c}\text { Tank } \\
\text { Treatment }\end{array}$ & Tile ID & $\begin{array}{c}\text { Tile Age } \\
\text { (days) }\end{array}$ & Coralite ID & $\begin{array}{l}\text { Size } \\
(\mu \mathrm{m}) \\
\end{array}$ & $\begin{array}{c}\text { Weight } \\
(\mu \mathrm{g})\end{array}$ & $\begin{array}{c}\text { ASN Weight } \\
\left(\mu \mathrm{g} \mathrm{mm}^{-1} \text { day }^{-1}\right)\end{array}$ \\
\hline $1200 \mathrm{ppm} \mathrm{CO}_{2}$ & & & $\mathrm{E}$ & 1409 & 399 & 12.99 \\
\hline \multirow{8}{*}{ Unfed } & 3 & 21 & $\mathrm{C}$ & 1574 & 384 & 13.09 \\
\hline & 6 & 21 & $\mathrm{E}$ & 1085 & 187 & 6.38 \\
\hline & 7 & 21 & $\mathrm{~A}$ & 1281 & 260 & 8.86 \\
\hline & & & B & 1419 & 356 & 12.14 \\
\hline & 12 & 25 & $\mathrm{~F}$ & 1451 & 378 & 10.83 \\
\hline & 14 & 24 & $\mathrm{~A}$ & 1627 & 456 & 13.60 \\
\hline & 17 & 24 & $\mathrm{~N}$ & 1189 & 170 & 5.07 \\
\hline & & & $\mathrm{O}$ & 1481 & 267 & 7.97 \\
\hline Tank 12 Average & & & & 1397 & 324 & 10.33 \\
\hline 13 & 3 & 21 & $\mathrm{~A}$ & 1404 & 332 & 12.03 \\
\hline 420 ppm $\mathrm{CO}_{2}$ & 6 & 21 & $\mathrm{~A}$ & 1293 & & \\
\hline \multirow[t]{11}{*}{ Unfed } & & & $\mathrm{F}$ & 1235 & 260 & 9.42 \\
\hline & & & G & 1361 & 297 & 10.76 \\
\hline & & & $\mathrm{H}(\mathrm{I})$ & 1074 & 159 & 5.76 \\
\hline & & & $\mathrm{K}$ & 1403 & 325 & 11.77 \\
\hline & & & $\mathrm{L}$ & 1148 & 191 & 6.92 \\
\hline & & & $\mathrm{N}$ & 1154 & 199 & 7.21 \\
\hline & 9 & 21 & $\mathrm{~A}$ & 1433 & 333 & 12.06 \\
\hline & & & $\mathrm{L}$ & 1589 & 431 & 15.61 \\
\hline & & & $\mathrm{F}$ & 1253 & 259 & 9.38 \\
\hline & & & G & 1407 & 282 & 10.22 \\
\hline & & & $\mathrm{E}$ & 1337 & 260 & 9.42 \\
\hline Tank 13 Average & & & & 1314 & 277 & 10.05 \\
\hline 14 & 2 & 22 & $\mathrm{~B}$ & 1462 & 279 & 9.62 \\
\hline $2700 \mathrm{ppm} \mathrm{CO}_{2}$ & & & $\mathrm{C}$ & 1254 & & \\
\hline \multirow[t]{13}{*}{ Unfed } & & & $\mathrm{D}$ & 1321 & & \\
\hline & 7 & 21 & $\mathrm{~F}$ & 1207 & 161 & 5.82 \\
\hline & & & G & 1198 & 180 & 6.50 \\
\hline & & & $\mathrm{K}$ & 1340 & 224 & 8.09 \\
\hline & & & $\mathrm{L}$ & 1305 & 204 & 7.37 \\
\hline & & & $\mathrm{H}(\mathrm{I})$ & 1248 & 196 & 7.08 \\
\hline & 8 & 21 & $\mathrm{E}$ & 1062 & 130 & 4.70 \\
\hline & & & $\mathrm{F}$ & 1490 & 290 & 10.48 \\
\hline & & & G & 1373 & & \\
\hline & & & $\mathrm{H}$ & 1457 & 230 & 8.31 \\
\hline & & & $\mathrm{J}$ & 1322 & & \\
\hline & & & $\mathrm{K}$ & 1407 & 202 & 7.30 \\
\hline & 15 & 24 & $\mathrm{~F}$ & 1328 & 207 & 6.54 \\
\hline Tank 14 Average & & & & 1318 & 209 & 7.44 \\
\hline
\end{tabular}


2011 skeletal size and weight data, continued

\begin{tabular}{|c|c|c|c|c|c|c|}
\hline $\begin{array}{c}\text { Tank } \\
\text { Treatment }\end{array}$ & Tile ID & $\begin{array}{c}\text { Tile Age } \\
\text { (days) }\end{array}$ & Coralite ID & $\begin{array}{l}\text { Size } \\
(\mu \mathrm{m})\end{array}$ & $\begin{array}{c}\text { Weight } \\
(\mu \mathrm{g})\end{array}$ & $\begin{array}{c}\text { ASN Weight } \\
\left(\mu \mathrm{g} \mathrm{mm}^{-1} \text { day }^{-1}\right)\end{array}$ \\
\hline 15 & 4 & 21 & $\mathrm{~A}$ & 1328 & 235 & 7.77 \\
\hline $1670 \mathrm{ppm} \mathrm{CO}_{2}$ & & & B & 1496 & & \\
\hline \multirow[t]{9}{*}{ Unfed } & & & $\mathrm{F}$ & 1343 & 267 & 8.83 \\
\hline & & & $\mathrm{L}$ & 1338 & 240 & 7.94 \\
\hline & & & M & 1579 & 437 & 14.46 \\
\hline & & & $\mathrm{J}$ & 1923 & 547 & 18.10 \\
\hline & & & K & 1454 & 311 & 10.29 \\
\hline & 6 & 21 & $\mathrm{~A}$ & 1587 & 376 & 12.44 \\
\hline & & & B & & & \\
\hline & & & $\mathrm{C}$ & 1252 & & \\
\hline & & & $\mathrm{D}$ & 1095 & 193 & 6.38 \\
\hline Tank 15 Average & & & & 1439 & 326 & 10.78 \\
\hline 16 & 1 & 22 & $\mathrm{~A}$ & 1519 & 358 & 12.07 \\
\hline $1200 \mathrm{ppm} \mathrm{CO}_{2}$ & & & $\mathrm{~B}(\mathrm{C})$ & 1404 & 279 & 9.41 \\
\hline \multirow[t]{11}{*}{ Unfed } & & & $\mathrm{D}$ & 1436 & 338 & 11.40 \\
\hline & & & $\mathrm{H}$ & 1216 & 200 & 6.74 \\
\hline & & & I & 1255 & 230 & 7.76 \\
\hline & & & $\mathrm{O}$ & 1279 & 204 & 6.88 \\
\hline & & & $\mathrm{P}$ & 1494 & 355 & 11.97 \\
\hline & & & $\mathrm{L}$ & 1266 & & \\
\hline & & & $\mathrm{S}$ & 1180 & 219 & 7.39 \\
\hline & & & G & 1457 & 325 & 10.96 \\
\hline & 10 & 24 & $\mathrm{G}$ & 1235 & 289 & 8.93 \\
\hline & & & $\mathrm{D}$ & 1437 & 353 & 10.91 \\
\hline & & & $\mathrm{C}$ & 1345 & 248 & 7.67 \\
\hline Tank 16 Average & & & & 1348 & 283 & 9.34 \\
\hline 17 & $?$ & 23 & $\mathrm{H}$ & 1540 & 665 & 13.50 \\
\hline $1200 \mathrm{ppm} \mathrm{CO}_{2}$ & & & I & 1870 & & \\
\hline \multirow[t]{10}{*}{ Unfed } & & & $\mathrm{J}$ & 1717 & & \\
\hline & & & K & 1643 & 412 & 8.36 \\
\hline & 17 & 23 & $\mathrm{E}$ & 1873 & 477 & 9.68 \\
\hline & & & $\mathrm{F}$ & 2782 & 809 & 16.42 \\
\hline & & & G & 2375 & 487 & 9.89 \\
\hline & & & $\mathrm{H}$ & 2993 & 1032 & 20.95 \\
\hline & & & I & 2313 & 698 & 14.17 \\
\hline & & & $\mathrm{J}$ & 2119 & 636 & 12.91 \\
\hline & & & K & 1817 & 382 & 7.76 \\
\hline & & & $\mathrm{L}$ & 2658 & 839 & 17.03 \\
\hline Tank 17 Average & & & & 2142 & 644 & 13.07 \\
\hline 18 & 4 & 24 & $?$ & 1241 & 195 & 4.17 \\
\hline
\end{tabular}


2011 skeletal size and weight data, continued

\begin{tabular}{|c|c|c|c|c|c|c|}
\hline $\begin{array}{c}\text { Tank } \\
\text { Treatment }\end{array}$ & Tile ID & $\begin{array}{c}\text { Tile Age } \\
\text { (days) }\end{array}$ & Coralite ID & $\begin{array}{l}\text { Size } \\
(\mu \mathrm{m})\end{array}$ & $\begin{array}{c}\text { Weight } \\
(\mu \mathrm{g})\end{array}$ & $\begin{array}{c}\text { ASN Weight } \\
\left(\mu \mathrm{g} \mathrm{mm}^{-1} \text { day }^{-1}\right)\end{array}$ \\
\hline $420 \mathrm{ppm} \mathrm{CO}_{2}$ & & & $\mathrm{C}$ & 1962 & 465 & 9.94 \\
\hline \multirow[t]{19}{*}{ Fed } & & & $\mathrm{D}$ & 1528 & 352 & 7.52 \\
\hline & & & $\mathrm{E}$ & 1403 & & \\
\hline & & & $\mathrm{F}$ & 1129 & 186 & 3.98 \\
\hline & 13 & 22 & B & 2264 & 560 & 13.06 \\
\hline & & & $\mathrm{C}$ & 1825 & 367 & 8.56 \\
\hline & & & $\mathrm{F}$ & 2008 & & \\
\hline & & & G & 1919 & 455 & 10.61 \\
\hline & & & $\mathrm{H}$ & 1829 & 458 & 10.68 \\
\hline & & & I & 2051 & 598 & 13.94 \\
\hline & & & $\mathrm{J}$ & 2112 & 709 & 16.53 \\
\hline & & & K & 1815 & & \\
\hline & & & $\mathrm{L}$ & 2534 & & \\
\hline & & & M & 1841 & 416 & 9.70 \\
\hline & & & $\mathrm{U}$ & 1976 & 522 & 12.17 \\
\hline & 14 & 22 & $\mathrm{~B}$ & 2087 & & \\
\hline & & & $\mathrm{C}$ & 2759 & 932 & 21.73 \\
\hline & & & $\mathrm{F}$ & 2023 & & \\
\hline & & & G & 2369 & 576 & 13.43 \\
\hline & & & $\mathrm{H}$ & 2261 & 549 & 12.80 \\
\hline Tank 18 Average & & & & 1949 & 489 & 11.26 \\
\hline 19 & 10 & 22 & $\mathrm{~A}$ & 1373 & 299 & 9.93 \\
\hline \multirow{11}{*}{$\begin{array}{c}420 \mathrm{ppm} \mathrm{CO}_{2} \\
\text { Unfed }\end{array}$} & & & B & 1033 & 160 & 5.31 \\
\hline & & & $\mathrm{J}$ & 1471 & 496 & 16.47 \\
\hline & 15 & 21 & $\mathrm{~A}(\mathrm{~F})$ & 1352 & 269 & 9.36 \\
\hline & & & $\mathrm{E}$ & 1384 & 301 & 10.47 \\
\hline & & & $\mathrm{D}$ & 1512 & 318 & 11.06 \\
\hline & & & $\mathrm{J}$ & 1476 & 347 & 12.07 \\
\hline & & & M & 1241 & 273 & 9.50 \\
\hline & 17 & 20 & $\mathrm{~A}$ & 1395 & 220 & 8.04 \\
\hline & & & $\mathrm{D}$ & 1386 & 229 & 8.36 \\
\hline & 18 & 20 & $\mathrm{~A}$ & 1398 & 304 & 11.10 \\
\hline & & & $\mathrm{C}$ & 1406 & 256 & 9.35 \\
\hline Tank 19 Average & & & & 1369 & 289 & 10.08 \\
\hline 20 & 11 & 21 & $\mathrm{~A}$ & 1827 & 411 & 11.77 \\
\hline $2700 \mathrm{ppm} \mathrm{CO} 2$ & & & $\mathrm{~B}$ & 1482 & 305 & 8.74 \\
\hline \multirow[t]{4}{*}{ Fed } & & & $\mathrm{C}$ & 1410 & 264 & 7.56 \\
\hline & & & G & 1903 & 350 & 10.02 \\
\hline & 12 & 21 & $\mathrm{~A}$ & 1807 & 417 & 11.94 \\
\hline & & & B & 1212 & 204 & 5.84 \\
\hline
\end{tabular}


2011 skeletal size and weight data, continued

\begin{tabular}{|c|c|c|c|c|c|c|}
\hline $\begin{array}{c}\text { Tank } \\
\text { Treatment }\end{array}$ & Tile ID & $\begin{array}{c}\text { Tile Age } \\
\text { (days) }\end{array}$ & Coralite ID & $\begin{array}{l}\text { Size } \\
(\mu \mathrm{m})\end{array}$ & $\begin{array}{c}\text { Weight } \\
(\mu \mathrm{g})\end{array}$ & $\begin{array}{c}\text { ASN Weight } \\
\left(\mu \mathbf{g ~ m m}^{-1} \text { day }^{-1}\right)\end{array}$ \\
\hline & & & $\mathrm{G}$ & 1785 & 385 & 11.03 \\
\hline & & & I & 1668 & 416 & 11.91 \\
\hline & & & $\mathrm{J}$ & 1605 & 301 & 8.62 \\
\hline & & & $\mathrm{H}$ & 1338 & 211 & 6.04 \\
\hline & 15 & 21 & $\mathrm{~B}$ & 1801 & & \\
\hline & & & $\mathrm{E}$ & 1968 & 420 & 12.03 \\
\hline & & & I & 1707 & 301 & 8.62 \\
\hline & & & $\mathrm{J}$ & 1763 & & \\
\hline Tank 20 Average & & & & 1663 & 332 & 9.51 \\
\hline 21 & 13 & 21 & $\mathrm{~A}$ & 1789 & 423 & 13.93 \\
\hline \multirow{10}{*}{$\begin{array}{c}1200 \mathrm{ppm} \mathrm{CO}_{2} \\
\text { Fed }\end{array}$} & & & B & 1690 & 427 & 14.07 \\
\hline & & & $\mathrm{L}$ & 1313 & 193 & 6.36 \\
\hline & & & M & 1548 & 288 & 9.49 \\
\hline & 15 & 20 & $\mathrm{C}$ & 1333 & 222 & 7.68 \\
\hline & & & $\mathrm{D}$ & 1282 & 211 & 7.30 \\
\hline & & & G & 1224 & 193 & 6.68 \\
\hline & & & $\mathrm{H}$ & 1311 & 233 & 8.06 \\
\hline & & & I & 1412 & 225 & 7.78 \\
\hline & & & $\mathrm{J}$ & 1635 & 370 & 12.80 \\
\hline & & & $\mathrm{K}$ & 1364 & 257 & 8.89 \\
\hline Tank 21 Average & & & & 1446 & 277 & 9.37 \\
\hline \multirow{9}{*}{$\begin{array}{c}22 \\
1670 \mathrm{ppm} \mathrm{CO}_{2} \\
\text { Fed }\end{array}$} & 2 & 23 & $\mathrm{E}$ & 1692 & & \\
\hline & 10 & 21 & $\mathrm{~A}$ & 1384 & 271 & 7.96 \\
\hline & 11 & 21 & $\mathrm{C}$ & 1887 & 370 & 10.87 \\
\hline & & & $\mathrm{E}$ & 1829 & 447 & 13.13 \\
\hline & 13 & 24 & A & 1801 & 243 & 6.24 \\
\hline & & & B & 1587 & 368 & 9.46 \\
\hline & 14 & 21 & $\mathrm{D}$ & 1445 & 251 & 7.37 \\
\hline & & & $\mathrm{F}$ & 1510 & 343 & 10.07 \\
\hline & & & G & 1456 & 336 & 9.87 \\
\hline Tank 22 Average & & & & 1621 & 329 & 9.37 \\
\hline 23 & 5 & 23 & $\mathrm{~A}$ & 1547 & & \\
\hline $2700 \mathrm{ppm} \mathrm{CO}_{2}$ & 11 & 22 & $\mathrm{~B}$ & 1476 & 271 & 7.86 \\
\hline \multirow[t]{7}{*}{ Fed } & & & $\mathrm{C}$ & 898 & 305 & 8.84 \\
\hline & & & $\mathrm{D}$ & 1736 & 327 & 9.48 \\
\hline & & & $\mathrm{E}$ & 1417 & & \\
\hline & 18 & 21 & $\mathrm{~A}$ & 1656 & 330 & 10.02 \\
\hline & & & $\mathrm{B}$ & 1504 & 287 & 8.72 \\
\hline & & & $\mathrm{D}$ & 1368 & 243 & 7.38 \\
\hline & & & $\mathrm{F}$ & 1666 & 406 & 12.33 \\
\hline
\end{tabular}


2011 skeletal size and weight data, continued

\begin{tabular}{|c|c|c|c|c|c|c|}
\hline $\begin{array}{c}\text { Tank } \\
\text { Treatment }\end{array}$ & Tile ID & $\begin{array}{c}\text { Tile Age } \\
\text { (days) }\end{array}$ & Coralite ID & $\begin{array}{l}\text { Size } \\
(\mu \mathrm{m})\end{array}$ & $\begin{array}{c}\text { Weight } \\
(\mu \mathrm{g})\end{array}$ & $\begin{array}{c}\text { ASN Weight } \\
\left(\mu \mathbf{g ~ m m}^{-1} \text { day }^{-1}\right)\end{array}$ \\
\hline & & & G & 1921 & 348 & 10.57 \\
\hline & & & $\mathrm{H}$ & 1699 & 339 & 10.30 \\
\hline & & & I & 1535 & 302 & 9.17 \\
\hline & & & $\mathrm{L}$ & 1766 & 399 & 12.12 \\
\hline & & & $\mathrm{N}$ & 1762 & & \\
\hline Tank 23 Average & & & & 1568 & 323 & 9.71 \\
\hline 24 & 4 & 24 & G & 911 & 185 & 7.90 \\
\hline \multirow{9}{*}{$\begin{array}{c}420 \text { ppm } \mathrm{CO}_{2} \\
\text { Unfed }\end{array}$} & & & $\mathrm{H}$ & & 165 & 7.04 \\
\hline & 5 & 24 & A & 1007 & & \\
\hline & & & $\mathrm{E}$ & 800 & 117 & 5.00 \\
\hline & & & $\mathrm{F}$ & 701 & 131 & 5.59 \\
\hline & & & G & 1137 & 218 & 9.31 \\
\hline & 13 & 23 & A & 919 & 204 & 9.09 \\
\hline & 10 & 23 & $\mathrm{~A}$ & 1001 & 195 & 8.69 \\
\hline & & & $\mathrm{E}$ & 1170 & & \\
\hline & & & $\mathrm{F}$ & 1138 & 252 & 11.23 \\
\hline Tank 24 Average & & & & 976 & 183 & 7.98 \\
\hline
\end{tabular}

Table B.1: Skeletal size (i.e., septa diameter), Weight (i.e., mass $\mathrm{CaCO}_{3}$ ), and Age-and SizeNormalized (ASN) weight of juvenile Favia fragum from the $2011 \mathrm{CO}_{2}$ x Feeding experiment. ASN Weight is the total mass of $\mathrm{CaCO}_{3}$ for the sample divided by the average skeletal size for the tank and the average age of the sample. 


\section{B.2 2011 Coral Tissue Lipid Data}

\begin{tabular}{|c|c|c|c|c|c|}
\hline Specimen & Sample ID & & $\begin{array}{c}\text { Total Lipid } \\
(\mu \mathrm{g})\end{array}$ & $\begin{array}{c}\text { N Lipid } \\
\left(\mu \text { g larvae }^{-1}\right)\end{array}$ & \\
\hline \multirow[t]{15}{*}{ Larvae } & LIP 1 & & 695 & 34.73 & \\
\hline & LIP 2 & & 630 & 31.50 & \\
\hline & LIP 3 & & 649 & 32.43 & \\
\hline & LIP 4 & & 588 & 29.38 & \\
\hline & LIP 5 & & 585 & 29.23 & \\
\hline & LIP 6 & & 634 & 31.70 & \\
\hline & LIP 7 & & 675 & 33.73 & \\
\hline & LIP 8 & & 550 & 27.50 & \\
\hline & LIP 9 & & 594 & 29.70 & \\
\hline & LIP 10 & & 612 & 30.60 & \\
\hline & LIP 11 & & 670 & 33.48 & \\
\hline & LIP 12 & & 602 & 30.08 & \\
\hline & LIP 13 & & 595 & 29.73 & \\
\hline & LIP 14 & & 621 & 31.03 & \\
\hline & LIP 15 & & 606 & 30.28 & \\
\hline Larval Average & & & 620 & 31.00 & \\
\hline $\begin{array}{c}\text { Tank } \\
\text { Treatment }\end{array}$ & Sample ID & $\begin{array}{l}\text { Average Age } \\
\text { (days) }\end{array}$ & $\begin{array}{c}\text { Total Lipid } \\
(\mu \mathrm{g})\end{array}$ & $\begin{array}{c}\text { AN Lipid } \\
\left(\mu \mathbf{g ~ m m}^{-2} \text { spat }^{-1}\right)\end{array}$ & $\begin{array}{c}\text { AAN Lipid } \\
\left(\mu \mathrm{g} \mathrm{mm}^{-2} \text { day }^{-1} \text { spat }^{-1}\right)\end{array}$ \\
\hline 1 & LIP 70 & 22.5 & 235 & 19.64 & 0.87 \\
\hline $1670 \mathrm{ppm} \mathrm{CO}_{2}$ & LIP 71 & 22.6 & 383 & 32.03 & 1.42 \\
\hline \multirow[t]{2}{*}{ Unfed } & LIP 72 & 22 & 288 & 24.08 & 1.09 \\
\hline & LIP 73 & 22.1 & 321 & 26.84 & 1.21 \\
\hline Tank 1 Average & & & 306 & 25.65 & 1.15 \\
\hline 6 & LIP 91 & 24 & 214 & 19.13 & 0.80 \\
\hline $1670 \mathrm{ppm} \mathrm{CO}_{2}$ & LIP 92 & 23.6 & 291 & 26.07 & 1.10 \\
\hline \multirow[t]{2}{*}{ Unfed } & LIP 93 & 23 & 228 & 20.43 & 0.89 \\
\hline & & 21 & 322 & 72.12 & 3.43 \\
\hline Tank 6 Average & & & 264 & 34.44 & 1.56 \\
\hline 10 & LIP 25 & 21 & 252 & 24.92 & 1.19 \\
\hline $1670 \mathrm{ppm} \mathrm{CO}_{2}$ & LIP 109 & 24.2 & 180 & 12.43 & 0.51 \\
\hline \multirow[t]{3}{*}{ Unfed } & LIP 115 & 24.5 & 159 & 10.97 & 0.45 \\
\hline & LIP 116 & 25.1 & 149 & 10.28 & 0.41 \\
\hline & LIP 117 & 25.3 & 195 & 13.46 & 0.53 \\
\hline Tank 10 Average & & & 187 & 14.41 & 0.62 \\
\hline 13 & LIP 30 & 21.4 & 246 & 18.09 & 0.85 \\
\hline $420 \mathrm{ppm} \mathrm{CO}_{2}$ & LIP 31 & 21.2 & 270 & 19.90 & 0.94 \\
\hline \multirow[t]{3}{*}{ Unfed } & LIP 32 & 21 & 248 & 18.28 & 0.87 \\
\hline & LIP 33 & 21 & 284 & 20.93 & 1.00 \\
\hline & LIP 34 & 21 & 316 & 23.29 & 1.11 \\
\hline
\end{tabular}


2011 lipid data, continued

\begin{tabular}{|c|c|c|c|c|c|}
\hline $\begin{array}{c}\text { Tank } \\
\text { Treatment }\end{array}$ & Sample ID & $\begin{array}{l}\text { Average Age } \\
\text { (days) }\end{array}$ & $\begin{array}{c}\text { Total Lipid } \\
(\mu \mathrm{g})\end{array}$ & $\begin{array}{c}\text { AN Lipid } \\
\left(\mu \mathrm{g} \mathrm{mm}^{-2} \text { spat }^{-1}\right)\end{array}$ & $\begin{array}{c}\text { AAN Lipid } \\
\left(\mu \mathbf{g ~ m m}^{-2} \text { day }^{-1} \text { spat }^{-1}\right)\end{array}$ \\
\hline Tank 13 Average & & & 273 & 20.10 & 0.95 \\
\hline 19 & LIP 45 & 20.3 & 279 & 18.96 & 0.93 \\
\hline $420 \mathrm{ppm} \mathrm{CO}_{2}$ & LIP 46 & 21 & 270 & 18.31 & 0.87 \\
\hline \multirow[t]{2}{*}{ Unfed } & LIP 47 & 20 & 189 & 14.23 & 0.71 \\
\hline & LIP 48 & 19.9 & 250 & 16.98 & 0.85 \\
\hline Tank 19 Average & & & 247 & 17.12 & 0.84 \\
\hline 24 & LIP 16 & 21.5 & 229 & 30.54 & 1.42 \\
\hline \multicolumn{6}{|l|}{$420 \mathrm{ppm} \mathrm{CO}_{2}$} \\
\hline \multicolumn{6}{|l|}{ Unfed } \\
\hline Tank 24 Average & & & 229 & 30.54 & 1.42 \\
\hline
\end{tabular}

Table B.2: Total lipid weight, Area-Normalized (AN) lipid weight and Age- and AreaNormalized (AAN) lipid weight. AN Lipid is the total mass of lipid measured for a given sample divided by the number of specimens in that sample and the circular area defined by the average skeletal size (i.e., septa diameter) for the tank (derived from Appendix B.1). AAN Lipid is AN Lipid divided by the average age of the sample. Lipid samples typically contain 10 corallites (20 larvae) with the exception of samples LIP 20, 25, and 47 which contained 4, 7, and 9 corallites respectively. Note: only a subset of samples collected were processed, specifically unfed corals at 420 and 1670 ppm $\mathrm{CO}_{2}$ for comparison with 2012 results. 


\section{B.3 2011 Symbiont Density Data}

\begin{tabular}{|c|c|c|c|c|c|}
\hline $\begin{array}{c}\text { Tank } \\
\text { Treatment }\end{array}$ & Sample ID & $\begin{array}{c}\text { Average Age } \\
(\text { days })\end{array}$ & $\begin{array}{c}\text { Symbionts } \\
\text { (cells) }\end{array}$ & $\begin{array}{l}\text { AN Symbionts } \\
\left(\times 10^{3} \text { cells }\right. \\
\left.\text { mm }^{-2} \text { spat }^{-1}\right)\end{array}$ & $\begin{array}{c}\text { AAN Symbionts } \\
\left(\times 10^{3} \text { cells }\right. \\
\left.\text { mm }^{-2} \text { day }^{-1} \text { spat }^{-1}\right)\end{array}$ \\
\hline 1 & ZOOX 59 & 22 & 22.3 & 9.32 & 0.42 \\
\hline $1670 \mathrm{ppm} \mathrm{CO}_{2}$ & ZOOX 60 & 22 & 25.6 & 10.70 & 0.49 \\
\hline \multirow[t]{3}{*}{ Unfed } & ZOOX 61 & 22 & 31.4 & 13.14 & 0.60 \\
\hline & ZOOX 62 & 22 & 35.8 & 14.99 & 0.68 \\
\hline & ZOOX 63 & 23 & 41.4 & 17.35 & 0.75 \\
\hline Tank 1 Average & & & 31.3 & 13.10 & 0.59 \\
\hline 6 & ZOOX 89 & 24 & 16.3 & 7.28 & 0.30 \\
\hline $1670 \mathrm{ppm} \mathrm{CO}_{2}$ & ZOOX 90 & 23 & 36.9 & 16.55 & 0.72 \\
\hline \multirow[t]{3}{*}{ Unfed } & ZOOX 91 & 23 & 21.8 & 9.74 & 0.42 \\
\hline & ZOOX 92 & 23 & 28.7 & 12.85 & 0.56 \\
\hline & ZOOX 93 & 23 & 44.8 & 20.05 & 0.87 \\
\hline Tank 6 Average & & & 29.7 & 13.29 & 0.58 \\
\hline 10 & ZOOX 136 & 25 & 51.0 & 17.65 & 0.71 \\
\hline 1670 ppm $\mathrm{CO}_{2}$ & ZOOX 137 & 25 & 17.8 & 6.17 & 0.25 \\
\hline \multirow[t]{3}{*}{ Unfed } & ZOOX 138 & 24 & 20.4 & 7.07 & 0.29 \\
\hline & ZOOX 139 & 25 & 37.2 & 12.87 & 0.51 \\
\hline & ZOOX 140 & 25 & 6.8 & 2.36 & 0.09 \\
\hline Tank 10 Average & & & 26.7 & 9.22 & 0.37 \\
\hline 13 & ZOOX 15 & 21 & 58.4 & 21.51 & 1.02 \\
\hline 420 ppm $\mathrm{CO}_{2}$ & ZOOX 16 & 21 & 33.4 & 12.32 & 0.59 \\
\hline \multirow[t]{3}{*}{ Unfed } & ZOOX 17 & 22 & 25.4 & 9.35 & 0.42 \\
\hline & ZOOX 18 & 22 & 20.3 & 7.48 & 0.34 \\
\hline & ZOOX 19 & 22 & 60.6 & 22.31 & 1.01 \\
\hline Tank 13 Average & & & 39.6 & 14.60 & 0.68 \\
\hline 19 & ZOOX 32 & 22 & 35.8 & 12.17 & 0.55 \\
\hline 420 ppm $\mathrm{CO}_{2}$ & ZOOX 33 & 22 & 25.6 & 8.68 & 0.39 \\
\hline \multirow[t]{3}{*}{ Unfed } & ZOOX 34 & 22 & 14.7 & 4.99 & 0.23 \\
\hline & ZOOX 35 & 20 & 11.1 & 3.76 & 0.19 \\
\hline & ZOOX 36 & 20 & 12.8 & 4.33 & 0.22 \\
\hline Tank 19 Average & & & 20.0 & 6.79 & 0.32 \\
\hline 24 & ZOOX 69 & 24 & 23.8 & 15.92 & 0.66 \\
\hline $420 \mathrm{ppm} \mathrm{CO}_{2}$ & ZOOX 70 & 23 & 26.8 & 17.88 & 0.78 \\
\hline Unfed & ZOOX 71 & 23 & 17.0 & 11.36 & 0.49 \\
\hline Tank 24 Average & & & 22.5 & 15.05 & 0.64 \\
\hline
\end{tabular}


Table B.3: Symbiont count, Area-Normalized (AN) Symbiont density, and Area- and AgeNormalized (AAN) Symbiont density for the $2011 \mathrm{CO}_{2} \times$ Feeding experiment. Symbionts is the average number of zooxanthellae cells counted in the hemacytometer grid, AN Symbionts Lipid is the total symbiont density for the sample divided by the number of specimens in that sample (1) and the circular area defined by the average skeletal size (i.e., septa diameter) for the tank (derived from Appendix B.1), and AAN Symbionts is AN Symbionts divided by the average age of the sample. 


\section{B.4 2011 Pigment Data}

\begin{tabular}{|c|c|c|c|c|c|}
\hline $\begin{array}{c}\text { Tank } \\
\text { Treatment }\end{array}$ & Sample ID & $\begin{array}{l}\text { Average Age } \\
\text { (days) }\end{array}$ & $\begin{array}{l}\text { Pigment } \\
\quad(\text { ng } c h l a)\end{array}$ & $\begin{array}{l}\text { AN Pigment } \\
\quad(\text { ng } \text { chl a } \\
\left.\text { mm }^{-2} \text { spat }^{-1}\right)\end{array}$ & $\begin{array}{c}\text { AANPigment } \\
(\mathrm{ng} \text { chl a } \\
\left.\mathrm{mm}^{-2} \mathrm{day}^{-1} \text { spat }^{-1}\right)\end{array}$ \\
\hline 1 & RNA 1 & 21.0 & 111.62 & 18.69 & 0.89 \\
\hline $1670 \mathrm{ppm} \mathrm{CO} 2$ & RNA 40 & 22.4 & 61.06 & 10.23 & 0.46 \\
\hline Unfed & RNA 41 & 22.2 & 170.59 & 28.57 & 1.29 \\
\hline Tank 1 Average & & & 114.42 & 19.16 & 0.88 \\
\hline 6 & RNA 56 & 24.0 & 128.59 & 23.04 & 0.96 \\
\hline $1670 \mathrm{ppm} \mathrm{CO}_{2}$ & RNA 57 & 24.0 & 118.68 & 21.27 & 0.89 \\
\hline Unfed & RNA 58 & 23.0 & 129.68 & 23.24 & 1.01 \\
\hline Tank 6 Average & & & 125.65 & 22.51 & 0.95 \\
\hline 10 & RNA 7 & 21.0 & 45.68 & 6.32 & 0.30 \\
\hline $\begin{array}{c}1670 \text { ppm } \mathrm{CO}_{2} \\
\text { Unfed }\end{array}$ & RNA 75 & 24.6 & 57.24 & 7.92 & 0.32 \\
\hline Tank 10 Average & & & 51.46 & 7.12 & 0.31 \\
\hline 13 & RNA 11 & 21.4 & 121.21 & 17.86 & 0.83 \\
\hline $420 \mathrm{ppm} \mathrm{CO}_{2}$ & RNA 12 & 21.0 & 85.35 & 12.58 & 0.60 \\
\hline Unfed & RNA 13 & 21.0 & 101.22 & 14.92 & 0.71 \\
\hline Tank 13 Average & & & 102.59 & 15.12 & 0.71 \\
\hline 19 & RNA 23 & 21.0 & 81.22 & 11.04 & 0.53 \\
\hline $420 \mathrm{ppm} \mathrm{CO}_{2}$ & RNA 24 & 21.2 & 65.96 & 8.96 & 0.42 \\
\hline Unfed & RNA 25 & 21.0 & 61.14 & 8.31 & 0.40 \\
\hline Tank 19 Average & & & 69.44 & 9.44 & 0.45 \\
\hline 24 & RNA 45 & 23.0 & 104.91 & 28.05 & 1.22 \\
\hline $420 \mathrm{ppm} \mathrm{CO}_{2}$ & RNA 46 & 23.6 & 170.81 & 45.67 & 1.94 \\
\hline Unfed & RNA 47 & 23.0 & 100.12 & 26.77 & 1.16 \\
\hline Tank 24 Average & & & 125.28 & 33.49 & 1.44 \\
\hline
\end{tabular}

Table B.4: Pigment mass, Area-Normalized (AN) Pigment density, and Area- and AgeNormalized (AAN) Pigment density for the $2011 \mathrm{CO}_{2} \times$ Feeding experiment. Pigment is the total mass chl $a$ in the sample, AN Pigment is the total pigment mass for the sample divided by the number of specimens in that sample (5) and the circular area defined by the average skeletal size (i.e., septa diameter) for the tank (derived from Appendix B.1), and AAN Pigment is AN Pigment divided by the average age of the sample. 


\section{B.5 2012 Skeletal Size and Weight Data}

\begin{tabular}{|c|c|c|c|c|c|c|}
\hline $\begin{array}{c}\text { Tank } \\
\text { Treatment }\end{array}$ & Tile ID & $\begin{array}{c}\text { Tile Age } \\
\text { (days) }\end{array}$ & Coralite ID & $\begin{array}{l}\text { Size } \\
(\mu \mathbf{m})\end{array}$ & $\begin{array}{c}\text { Weight } \\
(\mu \mathrm{g})\end{array}$ & $\begin{array}{c}\text { ASN Weight } \\
\left(\mu \mathrm{g} \mathrm{mm}^{-1} \text { day }^{-1}\right)\end{array}$ \\
\hline 1 & 2 & 14 & $\mathrm{~A}$ & 1215 & 133 & 8.66 \\
\hline $420 \mathrm{ppm} \mathrm{CO}_{2}$ & 6 & 14 & $\mathrm{~A}$ & 1150 & 124 & 8.07 \\
\hline \multirow[t]{17}{*}{ High Light } & & & B & 1008 & & \\
\hline & & & $\mathrm{C}$ & 1016 & & \\
\hline & & & $\mathrm{D}$ & 1017 & & \\
\hline & 9 & 14 & $\mathrm{~A}$ & 1009 & 140 & 9.11 \\
\hline & & & B & 1152 & 150 & 9.77 \\
\hline & & & $\mathrm{C}$ & 1209 & & \\
\hline & & & $\mathrm{D}$ & 1104 & & \\
\hline & & & $\mathrm{E}$ & 1114 & & \\
\hline & 13 & 14 & $\mathrm{~A}$ & 1062 & 123 & 8.01 \\
\hline & & & B & 1272 & & \\
\hline & & & $\mathrm{C}$ & 1006 & 132 & 8.59 \\
\hline & & & $\mathrm{D}$ & 947 & 101 & 6.58 \\
\hline & 14 & 14 & $\mathrm{~A}$ & 1140 & 102 & 6.64 \\
\hline & & & B & 1210 & 179 & 11.65 \\
\hline & & & $\mathrm{C}$ & 967 & & \\
\hline & & & $\mathrm{D}$ & 1228 & & \\
\hline & & & $\mathrm{E}$ & 1019 & 104 & 6.77 \\
\hline Tank 1 Average & & & & 1097 & 129 & 8.39 \\
\hline 2 & 2 & 14 & $\mathrm{~A}$ & 1130 & & \\
\hline $1670 \mathrm{ppm} \mathrm{CO}_{2}$ & 3 & 14 & $\mathrm{~A}$ & 1128 & 96 & 6.30 \\
\hline \multirow[t]{18}{*}{ High Light } & 4 & 14 & $\mathrm{~A}$ & 1098 & & \\
\hline & 5 & 14 & $\mathrm{~A}$ & 1135 & & \\
\hline & 6 & 14 & $\mathrm{~A}$ & 1333 & 165 & 10.82 \\
\hline & 7 & 14 & $\mathrm{~A}$ & 1271 & 172 & 11.28 \\
\hline & & & B & 1371 & 136 & 8.92 \\
\hline & 8 & 14 & $\mathrm{~A}$ & 1009 & 84 & 5.51 \\
\hline & & & B & 1252 & 132 & 8.66 \\
\hline & 9 & 14 & $\mathrm{~A}$ & 896 & 61 & 4.00 \\
\hline & & & B & 1068 & 101 & 6.62 \\
\hline & 10 & 14 & $\mathrm{~A}$ & 1049 & 93 & 6.10 \\
\hline & & & B & 1280 & 167 & 10.95 \\
\hline & 11 & 14 & A & 963 & 76 & 4.98 \\
\hline & & & B & 1146 & 100 & 6.56 \\
\hline & & & $\mathrm{C}$ & 858 & 46 & 3.02 \\
\hline & & & $\mathrm{D}$ & 984 & 85 & 5.57 \\
\hline & & & $\mathrm{E}$ & 1183 & & \\
\hline & & & $\mathrm{F}$ & 842 & 67 & 4.39 \\
\hline & & & G & 1122 & 110 & 7.21 \\
\hline
\end{tabular}


2012 skeletal size and weight data, continued

\begin{tabular}{|c|c|c|c|c|c|c|}
\hline \multirow[t]{16}{*}{$\begin{array}{c}\text { Tank } \\
\text { Treatment }\end{array}$} & Tile ID & $\begin{array}{c}\text { Tile Age } \\
\text { (days) }\end{array}$ & Coralite ID & $\begin{array}{l}\text { Size } \\
(\mu \mathrm{m})\end{array}$ & $\begin{array}{c}\text { Weight } \\
(\mu \mathrm{g})\end{array}$ & $\begin{array}{c}\text { ASN Weight } \\
\left(\mu \mathrm{g} \mathrm{mm}^{-1} \text { day }^{-1}\right)\end{array}$ \\
\hline & & & $\mathrm{H}$ & 1023 & 108 & 7.08 \\
\hline & 12 & 14 & $\mathrm{~A}$ & 1232 & & \\
\hline & & & B & 1143 & & \\
\hline & & & $\mathrm{C}$ & 1114 & 115 & 7.54 \\
\hline & 13 & 14 & $\mathrm{~A}$ & 1061 & & \\
\hline & & & B & & 82 & 5.38 \\
\hline & & & $\mathrm{C}$ & 914 & 105 & 6.89 \\
\hline & & & $\mathrm{D}$ & 1173 & 122 & 8.00 \\
\hline & & & $\mathrm{E}$ & 807 & 64 & 4.20 \\
\hline & & & $\mathrm{F}$ & 919 & & \\
\hline & & & G & 1211 & & \\
\hline & 14 & 14 & $\mathrm{~A}$ & 1296 & 127 & 8.33 \\
\hline & & & B & 953 & 72 & 4.72 \\
\hline & & & $\mathrm{C}$ & 989 & 82 & 5.38 \\
\hline & & & $\mathrm{D}$ & 1081 & 99 & 6.49 \\
\hline Tank 2 Average & & & & 1089 & 103 & 6.73 \\
\hline 3 & 3 & 14 & $\mathrm{~A}$ & 1226 & 135 & 8.25 \\
\hline $1670 \mathrm{ppm} \mathrm{CO} 2$ & 4 & 14 & $\mathrm{~A}$ & 1229 & & \\
\hline \multirow[t]{22}{*}{ High Light } & & & B & 1050 & 105 & 6.42 \\
\hline & & & $\mathrm{C}$ & 1239 & & \\
\hline & 9 & 14 & $\mathrm{~A}$ & 1281 & & \\
\hline & & & $\mathrm{B}$ & & & \\
\hline & & & $\mathrm{C}$ & 1408 & & \\
\hline & & & $\mathrm{D}$ & 1209 & 120 & 7.33 \\
\hline & & & $\mathrm{E}$ & 1390 & 190 & 11.61 \\
\hline & & & $\mathrm{F}$ & 1323 & 192 & 11.73 \\
\hline & 10 & 14 & $\mathrm{~A}$ & 1062 & 70 & 4.28 \\
\hline & & & B & 926 & 65 & 3.97 \\
\hline & & & $\mathrm{C}$ & 1320 & 144 & 8.80 \\
\hline & & & $\mathrm{D}$ & 1212 & 105 & 6.42 \\
\hline & 12 & 14 & $\mathrm{~A}$ & & 124 & 7.58 \\
\hline & & & $\mathrm{B}$ & 1213 & & \\
\hline & & & $\mathrm{C}$ & 1073 & 102 & 6.23 \\
\hline & & & $\mathrm{D}$ & 1387 & 160 & 9.78 \\
\hline & 14 & 14 & $\mathrm{~A}$ & 924 & 84 & 5.13 \\
\hline & & & B & 1291 & 180 & 11.00 \\
\hline & & & $\mathrm{C}$ & 1062 & 120 & 7.33 \\
\hline & 15 & 14 & $\mathrm{~A}$ & 1157 & 133 & 8.13 \\
\hline & & & B & 1225 & & \\
\hline & & & $\mathrm{C}$ & 1106 & 156 & 9.53 \\
\hline
\end{tabular}


2012 skeletal size and weight data, continued

\begin{tabular}{|c|c|c|c|c|c|c|}
\hline $\begin{array}{c}\text { Tank } \\
\text { Treatment }\end{array}$ & Tile ID & $\begin{array}{c}\text { Tile Age } \\
\text { (days) }\end{array}$ & Coralite ID & $\begin{array}{l}\text { Size } \\
(\mu \mathrm{m})\end{array}$ & $\begin{array}{c}\text { Weight } \\
(\mu \mathrm{g})\end{array}$ & $\begin{array}{c}\text { ASN Weight } \\
\left(\mu \mathrm{g} \mathrm{mm}^{-1} \text { day }^{-1}\right)\end{array}$ \\
\hline & & & $\mathrm{D}$ & 1021 & 111 & 6.78 \\
\hline & & & $\mathrm{E}$ & 1101 & 116 & 7.09 \\
\hline & & & $\mathrm{F}$ & & & \\
\hline & & & $\mathrm{G}$ & 849 & & \\
\hline & & & $\mathrm{H}$ & 1034 & & \\
\hline & & & I & 1116 & & \\
\hline & & & $\mathrm{J}$ & 1302 & 168 & 10.27 \\
\hline & & & $\mathrm{K}$ & 1164 & 106 & 6.48 \\
\hline Tank 3 Average & & & & 1169 & 128 & 7.82 \\
\hline 4 & 2 & 14 & $\mathrm{~A}$ & 958 & & \\
\hline $420 \mathrm{ppm} \mathrm{CO}_{2}$ & 3 & 14 & $\mathrm{~A}$ & 963 & & \\
\hline \multirow[t]{24}{*}{ High Light } & & & B & 1018 & 96 & 6.92 \\
\hline & 4 & 14 & $\mathrm{~A}$ & 1229 & & \\
\hline & 7 & 14 & $\mathrm{~A}$ & 914 & 69 & 4.98 \\
\hline & & & $\mathrm{B}$ & 970 & & \\
\hline & & & $\mathrm{C}$ & 1199 & 92 & 6.63 \\
\hline & 8 & 14 & $\mathrm{~A}$ & 1127 & 113 & 8.15 \\
\hline & & & $\mathrm{B}$ & 1014 & 86 & 6.20 \\
\hline & & & $\mathrm{C}$ & 1092 & 118 & 8.51 \\
\hline & & & $\mathrm{D}$ & 1134 & 165 & 11.90 \\
\hline & & & $\mathrm{E}$ & 1053 & 99 & 7.14 \\
\hline & 9 & 14 & $\mathrm{~A}$ & 1167 & 111 & 8.01 \\
\hline & & & $\mathrm{B}$ & 928 & & \\
\hline & 10 & 14 & $\mathrm{~A}$ & 839 & & \\
\hline & 11 & 14 & $\mathrm{~A}$ & 921 & 43 & 3.10 \\
\hline & 12 & 14 & $\mathrm{~A}$ & 922 & & \\
\hline & 14 & 14 & $\mathrm{~A}$ & 883 & 78 & 5.63 \\
\hline & & & B & 892 & & \\
\hline & & & $\mathrm{C}$ & 776 & 64 & 4.62 \\
\hline & & & $\mathrm{D}$ & 990 & 76 & 5.48 \\
\hline & & & $\mathrm{E}$ & 917 & 89 & 6.42 \\
\hline & & & $\mathrm{F}$ & 1050 & 105 & 7.57 \\
\hline & & & G & 867 & 65 & 4.69 \\
\hline & & & $\mathrm{H}$ & 930 & 82 & 5.91 \\
\hline & & & I & 999 & & \\
\hline Tank 4 Average & & & & 990 & 91 & 6.58 \\
\hline 5 & 1 & 14 & $\mathrm{~A}$ & 1341 & 225 & 13.80 \\
\hline $420 \mathrm{ppm} \mathrm{CO}_{2}$ & 2 & 14 & $\mathrm{~A}$ & 1387 & 281 & 17.24 \\
\hline High Light & 4 & 14 & $\mathrm{~A}$ & 1213 & 175 & 10.74 \\
\hline & 8 & 14 & $\mathrm{~A}$ & 1480 & 326 & 20.00 \\
\hline
\end{tabular}


2012 skeletal size and weight data, continued

\begin{tabular}{|c|c|c|c|c|c|c|}
\hline $\begin{array}{c}\text { Tank } \\
\text { Treatment }\end{array}$ & Tile ID & $\begin{array}{c}\text { Tile Age } \\
\text { (days) }\end{array}$ & Coralite ID & $\begin{array}{l}\text { Size } \\
(\mu \mathrm{m})\end{array}$ & $\begin{array}{c}\text { Weight } \\
(\mu \mathrm{g})\end{array}$ & $\begin{array}{c}\text { ASN Weight } \\
\left(\mu \mathbf{g ~ m m}^{-1} \text { day }^{-1}\right)\end{array}$ \\
\hline & & & $\mathrm{B}$ & 1221 & 215 & 13.19 \\
\hline & & & $\mathrm{C}$ & 1243 & 240 & 14.72 \\
\hline & & & $\mathrm{x}$ & & 331 & 20.31 \\
\hline & 10 & 14 & $\mathrm{~A}$ & 1197 & 181 & 11.10 \\
\hline & & & $\mathrm{B}$ & 1363 & 259 & 15.89 \\
\hline & & & $\mathrm{C}$ & 1275 & & \\
\hline & 11 & 14 & $\mathrm{~A}$ & 1024 & 71 & 4.36 \\
\hline & & & $\mathrm{B}$ & 818 & & \\
\hline & & & $\mathrm{C}$ & 1045 & 70 & 4.29 \\
\hline & & & $\mathrm{D}$ & 1013 & 51 & 3.13 \\
\hline & & & $\mathrm{E}$ & 1169 & 90 & 5.52 \\
\hline & & & $\mathrm{F}$ & 1060 & 86 & 5.28 \\
\hline & 12 & 14 & $\mathrm{~A}$ & 896 & 62 & 3.80 \\
\hline & & & $\mathrm{B}$ & 1189 & 144 & 8.83 \\
\hline & & & $\mathrm{C}$ & 1114 & 110 & 6.75 \\
\hline & 14 & 14 & $\mathrm{~A}$ & 1197 & & \\
\hline & & & B & 1106 & & \\
\hline & & & $\mathrm{C}$ & 1073 & 77 & 4.72 \\
\hline & & & $\mathrm{D}$ & 1194 & & \\
\hline Tank 5 Average & & & & 1164 & 166 & 10.20 \\
\hline 6 & 3 & 14 & $\mathrm{~A}$ & 1053 & 97 & 5.79 \\
\hline 1670 ppm $\mathrm{CO}_{2}$ & 6 & 14 & $\mathrm{~A}$ & 1262 & 115 & 6.87 \\
\hline \multirow[t]{18}{*}{ High Light } & & & B & 1119 & 116 & 6.93 \\
\hline & 8 & 14 & $\mathrm{~A}$ & 1081 & 84 & 5.02 \\
\hline & & & B & 1262 & 124 & 7.41 \\
\hline & 9 & 14 & $\mathrm{~A}$ & 1202 & 146 & 8.72 \\
\hline & & & B & 1044 & 107 & 6.39 \\
\hline & 10 & 14 & $\mathrm{~A}$ & 1239 & 131 & 7.83 \\
\hline & & & B & 1266 & 156 & 9.32 \\
\hline & & & $\mathrm{C}$ & 1367 & 163 & 9.74 \\
\hline & 11 & 14 & $\mathrm{~A}$ & 1203 & 166 & 9.92 \\
\hline & & & B & 1218 & 142 & 8.48 \\
\hline & 12 & 14 & $\mathrm{~A}$ & 932 & 85 & 5.08 \\
\hline & & & B & 1091 & 118 & 7.05 \\
\hline & 13 & 14 & $\mathrm{~A}$ & 1359 & & \\
\hline & & & B & 1154 & 141 & 8.42 \\
\hline & 14 & 14 & $\mathrm{~A}$ & 1229 & & \\
\hline & & & B & 1230 & 151 & 9.02 \\
\hline & 15 & 14 & $\mathrm{~A}$ & 1245 & 160 & 9.56 \\
\hline & & & B & 1360 & 155 & 9.26 \\
\hline
\end{tabular}


2012 skeletal size and weight data, continued

\begin{tabular}{|c|c|c|c|c|c|c|}
\hline $\begin{array}{c}\text { Tank } \\
\text { Treatment }\end{array}$ & Tile ID & $\begin{array}{c}\text { Tile Age } \\
\text { (days) }\end{array}$ & Coralite ID & $\begin{array}{l}\text { Size } \\
(\mu \mathrm{m})\end{array}$ & $\begin{array}{c}\text { Weight } \\
(\mu \mathrm{g})\end{array}$ & $\begin{array}{c}\text { ASN Weight } \\
\left(\mu \mathrm{g} \mathrm{mm}^{-1} \text { day }^{-1}\right)\end{array}$ \\
\hline Tank 6 Average & & & & 1196 & 131 & 7.82 \\
\hline 7 & 3 & 14 & $\mathrm{~A}$ & 1341 & & \\
\hline $1670 \mathrm{ppm} \mathrm{CO}_{2}$ & 6 & 14 & $\mathrm{~A}$ & 1052 & 110 & 7.22 \\
\hline \multirow[t]{29}{*}{ High Light } & & & B & 953 & & \\
\hline & 7 & 14 & $\mathrm{~A}$ & 1345 & 119 & 7.81 \\
\hline & & & B & 1214 & 86 & 5.64 \\
\hline & & & $\mathrm{C}$ & 910 & 56 & 3.67 \\
\hline & & & $\mathrm{D}$ & 1186 & 177 & 11.61 \\
\hline & & & $\mathrm{E}$ & 1050 & 72 & 4.72 \\
\hline & & & $\mathrm{F}$ & 1121 & 93 & 6.10 \\
\hline & & & G & 1196 & 84 & 5.51 \\
\hline & & & $\mathrm{H}$ & 909 & 104 & 6.82 \\
\hline & & & I & 1206 & 109 & 7.15 \\
\hline & & & $\mathrm{J}$ & 1132 & & \\
\hline & 8 & 14 & $\mathrm{~A}$ & 1274 & 136 & 8.92 \\
\hline & & & B & & & \\
\hline & & & $\mathrm{C}$ & 818 & 57 & 3.74 \\
\hline & & & $\mathrm{D}$ & 1126 & 122 & 8.00 \\
\hline & & & $\mathrm{E}$ & 1168 & 118 & 7.74 \\
\hline & 12 & 14 & $\mathrm{~A}$ & 1125 & & \\
\hline & & & B & 1039 & 84 & 5.51 \\
\hline & & & $\mathrm{C}$ & 1056 & 122 & 8.00 \\
\hline & & & $\mathrm{D}$ & 1052 & & \\
\hline & 13 & 14 & $\mathrm{~A}$ & 1092 & & \\
\hline & & & B & 869 & 71 & 4.66 \\
\hline & & & $\mathrm{C}$ & 1162 & 90 & 5.91 \\
\hline & & & $\mathrm{D}$ & 947 & 73 & 4.79 \\
\hline & & & $\mathrm{E}$ & 1125 & 120 & 7.87 \\
\hline & & & $\mathrm{F}$ & 991 & 89 & 5.84 \\
\hline & & & G & 1183 & 148 & 9.71 \\
\hline & & & $\mathrm{H}$ & 715 & 61 & 4.00 \\
\hline & 14 & 14 & $\mathrm{~A}$ & 1303 & 203 & 13.32 \\
\hline Tank 7 Average & & & & 1089 & 104 & 6.85 \\
\hline \multirow{7}{*}{$\begin{array}{c}8 \\
420 \text { ppm } \mathrm{CO}_{2} \\
\text { High Light }\end{array}$} & 1 & 14 & $\mathrm{~A}$ & 870 & 111 & 6.66 \\
\hline & 3 & 14 & $\mathrm{~A}$ & 1173 & 108 & 6.48 \\
\hline & & & B & 1103 & & \\
\hline & 5 & 14 & $\mathrm{~A}$ & 1237 & 221 & 13.25 \\
\hline & & & B & 1335 & 221 & 13.25 \\
\hline & & & $\mathrm{C}$ & 1344 & 218 & 13.07 \\
\hline & 6 & 14 & $\mathrm{~A}$ & 1257 & 185 & 11.10 \\
\hline
\end{tabular}


2012 skeletal size and weight data, continued

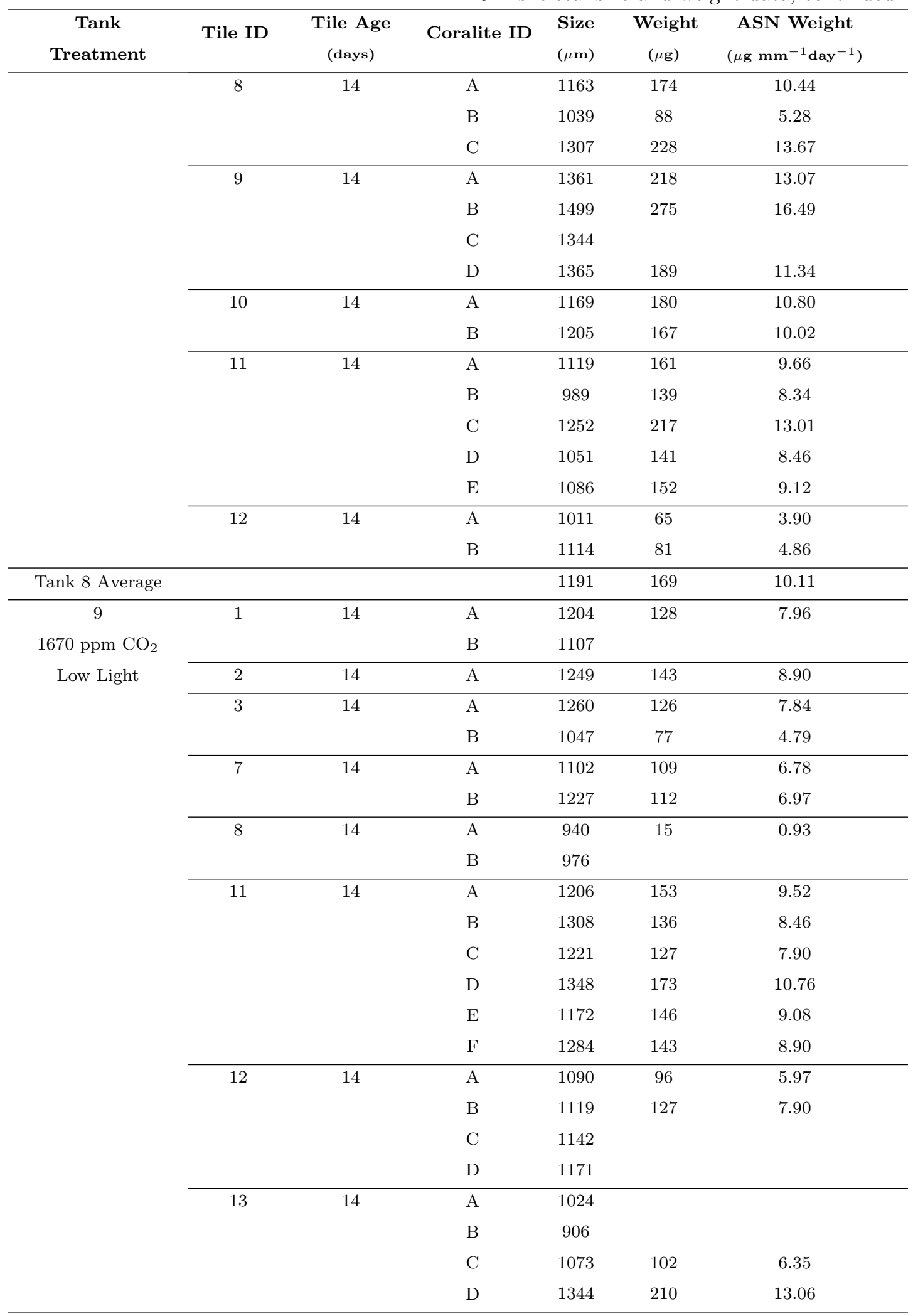


2012 skeletal size and weight data, continued

\begin{tabular}{|c|c|c|c|c|c|c|}
\hline $\begin{array}{c}\text { Tank } \\
\text { Treatment }\end{array}$ & Tile ID & $\begin{array}{c}\text { Tile Age } \\
\text { (days) }\end{array}$ & Coralite ID & $\begin{array}{l}\text { Size } \\
(\mu \mathrm{m})\end{array}$ & $\begin{array}{c}\text { Weight } \\
(\mu \mathrm{g})\end{array}$ & $\begin{array}{c}\text { ASN Weight } \\
\left(\mu \mathbf{g ~ m m}^{-1} \text { day }^{-1}\right)\end{array}$ \\
\hline & & & $\mathrm{E}$ & 941 & 58 & 3.61 \\
\hline & & & F & 1180 & 136 & 8.46 \\
\hline & & & G & 1267 & & \\
\hline & 14 & 14 & $\mathrm{~A}$ & 1108 & 107 & 6.66 \\
\hline & & & $\mathrm{B}$ & 1057 & 75 & 4.67 \\
\hline & & & $\mathrm{C}$ & & 122 & 7.59 \\
\hline & 15 & 14 & $\mathrm{~A}$ & 1039 & & \\
\hline & & & B & 1337 & 211 & 13.13 \\
\hline Tank 9 Average & & & & 1148 & 123 & 7.66 \\
\hline 11 & 2 & 14 & $\mathrm{~A}$ & 1014 & 241 & 14.29 \\
\hline $420 \mathrm{ppm} \mathrm{CO}_{2}$ & & & $\mathrm{~B}$ & 744 & 111 & 6.58 \\
\hline \multirow[t]{27}{*}{ Low Light } & & & $\mathrm{C}$ & 1107 & & \\
\hline & 3 & 14 & $\mathrm{~A}$ & 1158 & 177 & 10.49 \\
\hline & 4 & 14 & $\mathrm{~A}$ & 1242 & 191 & 11.32 \\
\hline & 5 & 14 & $\mathrm{~A}$ & 1374 & 265 & 15.71 \\
\hline & & & B & 1149 & & \\
\hline & 8 & 14 & $\mathrm{~A}$ & 1385 & 243 & 14.41 \\
\hline & & & B & 1327 & 243 & 14.41 \\
\hline & & & $\mathrm{C}$ & 1276 & & \\
\hline & 10 & 14 & $\mathrm{~A}$ & 1139 & 152 & 9.01 \\
\hline & & & $\mathrm{B}$ & 1261 & 181 & 10.73 \\
\hline & & & $\mathrm{C}$ & 1226 & 187 & 11.09 \\
\hline & & & $\mathrm{D}$ & 1219 & 178 & 10.55 \\
\hline & 13 & 14 & $\mathrm{~A}$ & 1291 & 136 & 8.06 \\
\hline & & & B & 1217 & 195 & 11.56 \\
\hline & 15 & 14 & $\mathrm{~A}$ & 1199 & 184 & 10.91 \\
\hline & & & $\mathrm{B}$ & 1263 & 180 & 10.67 \\
\hline & & & $\mathrm{C}$ & 1127 & 109 & 6.46 \\
\hline & & & $\mathrm{D}$ & 1349 & 243 & 14.41 \\
\hline & & & $\mathrm{E}$ & 1362 & 252 & 14.94 \\
\hline & & & $\mathrm{F}$ & 1165 & 146 & 8.66 \\
\hline & & & G & 1150 & 149 & 8.83 \\
\hline & & & $\mathrm{H}$ & 1149 & & \\
\hline & & & I & 1200 & & \\
\hline & & & $\mathrm{J}$ & 1226 & 178 & 10.55 \\
\hline & & & $\mathrm{K}$ & 1118 & 108 & 6.40 \\
\hline & & & $\mathrm{L}$ & 1231 & & \\
\hline & & & M & 1269 & & \\
\hline Tank 11 Average & & & & 1205 & 184 & 10.91 \\
\hline 12 & 2 & 14 & $\mathrm{~A}$ & 1284 & 158 & 9.22 \\
\hline
\end{tabular}


2012 skeletal size and weight data, continued

\begin{tabular}{|c|c|c|c|c|c|c|}
\hline $\begin{array}{c}\text { Tank } \\
\text { Treatment }\end{array}$ & Tile ID & $\begin{array}{c}\text { Tile Age } \\
\text { (days) }\end{array}$ & Coralite ID & $\begin{array}{l}\text { Size } \\
(\mu \mathrm{m})\end{array}$ & $\begin{array}{c}\text { Weight } \\
(\mu \mathrm{g})\end{array}$ & $\begin{array}{c}\text { ASN Weight } \\
\left(\mu \mathrm{g} \mathrm{mm}^{-1} \text { day }^{-1}\right)\end{array}$ \\
\hline $1670 \mathrm{ppm} \mathrm{CO}_{2}$ & 3 & 14 & $\mathrm{~A}$ & 1260 & 130 & 7.59 \\
\hline \multirow[t]{24}{*}{ Low Light } & 4 & 14 & $\mathrm{~A}$ & 1180 & 162 & 9.45 \\
\hline & & & $\mathrm{B}$ & 1113 & 86 & 5.02 \\
\hline & & & $\mathrm{C}$ & 1216 & 151 & 8.81 \\
\hline & 7 & 14 & $\mathrm{~A}$ & 1179 & 138 & 8.05 \\
\hline & & & B & 1421 & & \\
\hline & 9 & 14 & $\mathrm{~A}$ & 1144 & 129 & 7.53 \\
\hline & & & B & 1132 & 116 & 6.77 \\
\hline & 10 & 14 & $\mathrm{~A}$ & 1129 & 115 & 6.71 \\
\hline & & & B & 1269 & 163 & 9.51 \\
\hline & 11 & 14 & $\mathrm{~A}$ & 1337 & & \\
\hline & & & B & 1360 & 186 & 10.85 \\
\hline & 12 & 14 & $\mathrm{~A}$ & 1307 & 177 & 10.33 \\
\hline & & & B & 1061 & 104 & 6.07 \\
\hline & 13 & 14 & $\mathrm{~A}$ & 1042 & 78 & 4.55 \\
\hline & & & B & 1204 & 138 & 8.05 \\
\hline & & & $\mathrm{C}$ & 1155 & & \\
\hline & & & $\mathrm{D}$ & 1255 & 143 & 8.34 \\
\hline & 14 & 14 & $\mathrm{~A}$ & 1213 & 166 & 9.69 \\
\hline & & & B & 1163 & 137 & 7.99 \\
\hline & & & $\mathrm{C}$ & 1343 & 180 & 10.50 \\
\hline & 15 & 14 & $\mathrm{~A}$ & 1374 & 180 & 10.50 \\
\hline & & & B & 1210 & 168 & 9.80 \\
\hline & 16 & 14 & $\mathrm{~A}$ & 1224 & 167 & 9.75 \\
\hline & & & B & 1252 & 160 & 9.34 \\
\hline Tank 12 Average & & & & 1224 & 145 & 8.45 \\
\hline 13 & 1 & 14 & $\mathrm{~A}$ & 1085 & & \\
\hline \multirow{13}{*}{$\begin{array}{c}1670 \text { ppm } \mathrm{CO}_{2} \\
\text { Low Light }\end{array}$} & & & B & 751 & & \\
\hline & 6 & 14 & $\mathrm{~A}$ & 1172 & 129 & 8.99 \\
\hline & & & $\mathrm{B}$ & 1164 & 106 & 7.39 \\
\hline & & & $\mathrm{C}$ & 1248 & & \\
\hline & 9 & 14 & $\mathrm{~A}$ & 998 & 65 & 4.53 \\
\hline & & & B & 1192 & 82 & 5.72 \\
\hline & & & $\mathrm{C}$ & 1087 & 83 & 5.79 \\
\hline & 11 & 14 & $\mathrm{~A}$ & 934 & 62 & 4.32 \\
\hline & & & $\mathrm{B}$ & & 42 & 2.93 \\
\hline & & & $\mathrm{C}$ & 905 & 63 & 4.39 \\
\hline & 13 & 14 & $\mathrm{~A}$ & 814 & 58 & 4.04 \\
\hline & & & B & 974 & & \\
\hline & & & $\mathrm{C}$ & 885 & & \\
\hline
\end{tabular}


2012 skeletal size and weight data, continued

\begin{tabular}{|c|c|c|c|c|c|c|}
\hline $\begin{array}{c}\text { Tank } \\
\text { Treatment }\end{array}$ & Tile ID & $\begin{array}{c}\text { Tile Age } \\
\text { (days) }\end{array}$ & Coralite ID & $\begin{array}{l}\text { Size } \\
(\mu \mathrm{m})\end{array}$ & $\begin{array}{c}\text { Weight } \\
(\mu \mathrm{g})\end{array}$ & $\begin{array}{c}\text { ASN Weight } \\
\left(\mu \mathrm{g} \mathrm{mm}^{-1} \text { day }^{-1}\right)\end{array}$ \\
\hline & & & $\mathrm{D}$ & 1061 & & \\
\hline & & & $\mathrm{E}$ & 1139 & 107 & 7.46 \\
\hline & & & $\mathrm{F}$ & 1182 & 100 & 6.97 \\
\hline & & & G & 1087 & 95 & 6.62 \\
\hline & & & $\mathrm{H}$ & 850 & 75 & 5.23 \\
\hline & & & I & 944 & & \\
\hline & & & $\mathrm{J}$ & 1125 & 117 & 8.16 \\
\hline & 14 & 14 & $\mathrm{~A}$ & 1029 & 90 & 6.27 \\
\hline & & & B & 1182 & 133 & 9.27 \\
\hline & & & $\mathrm{C}$ & 861 & 46 & 3.21 \\
\hline & & & $\mathrm{D}$ & 1049 & 85 & 5.93 \\
\hline & & & $\mathrm{E}$ & 1197 & 108 & 7.53 \\
\hline & & & $\mathrm{F}$ & 788 & 58 & 4.04 \\
\hline & & & $\mathrm{H}$ & 925 & 73 & 5.09 \\
\hline & & & I & 1086 & 114 & 7.95 \\
\hline & & & $\mathrm{J}$ & 1157 & 112 & 7.81 \\
\hline & & & G & 865 & & \\
\hline Tank 13 Average & & & & 1025 & 87 & 6.07 \\
\hline 14 & 2 & 14 & $\mathrm{~A}$ & 1172 & 161 & 9.39 \\
\hline $420 \mathrm{ppm} \mathrm{CO}_{2}$ & & & B & 1176 & 161 & 9.39 \\
\hline \multirow[t]{20}{*}{ Low Light } & & & $\mathrm{C}$ & 1354 & 223 & 13.01 \\
\hline & & & $\mathrm{D}$ & 1119 & 155 & 9.04 \\
\hline & & & $\mathrm{E}$ & 1346 & 239 & 13.95 \\
\hline & 8 & 14 & $\mathrm{~A}$ & 1155 & 171 & 9.98 \\
\hline & & & B & 1267 & 176 & 10.27 \\
\hline & & & $\mathrm{C}$ & 1242 & 171 & 9.98 \\
\hline & & & D & 1577 & & \\
\hline & & & $\mathrm{E}$ & 1309 & & \\
\hline & 10 & 14 & A & 1099 & 109 & 6.36 \\
\hline & & & B & 834 & 44 & 2.57 \\
\hline & & & $\mathrm{C}$ & 1211 & & \\
\hline & 11 & 14 & A & 1238 & 217 & 12.66 \\
\hline & & & B & 1206 & 181 & 10.56 \\
\hline & & & $\mathrm{C}$ & 1259 & 173 & 10.09 \\
\hline & & & $\mathrm{D}$ & 1379 & 277 & 16.16 \\
\hline & 12 & 14 & A & 1262 & 76 & 4.43 \\
\hline & & & $\mathrm{C}$ & 1184 & 79 & 4.61 \\
\hline & & & D & 1242 & 48 & 2.80 \\
\hline & & & $\mathrm{E}$ & 849 & 27 & 1.58 \\
\hline & & & $\mathrm{F}$ & 1286 & 84 & 4.90 \\
\hline
\end{tabular}


2012 skeletal size and weight data, continued

\begin{tabular}{|c|c|c|c|c|c|c|}
\hline $\begin{array}{c}\text { Tank } \\
\text { Treatment }\end{array}$ & Tile ID & $\begin{array}{l}\text { Tile Age } \\
\text { (days) }\end{array}$ & Coralite ID & $\begin{array}{l}\text { Size } \\
(\mu \mathrm{m})\end{array}$ & $\begin{array}{c}\text { Weight } \\
(\mu \mathrm{g})\end{array}$ & $\begin{array}{c}\text { ASN Weight } \\
\left(\mu \mathrm{g} \mathrm{mm}^{-1} \text { day }^{-1}\right)\end{array}$ \\
\hline & & & G & 1392 & & \\
\hline Tank 14 Average & & & & 1224 & 146 & 8.51 \\
\hline 15 & 1 & 14 & $\mathrm{~A}$ & 1174 & 162 & 9.94 \\
\hline $420 \mathrm{ppm} \mathrm{CO}_{2}$ & & & B & 1148 & 132 & 8.10 \\
\hline \multirow[t]{24}{*}{ Low Light } & & & $\mathrm{C}$ & 1170 & 158 & 9.69 \\
\hline & 2 & 14 & $\mathrm{~A}$ & 1326 & 183 & 11.23 \\
\hline & 3 & 14 & $\mathrm{~A}$ & 1176 & 173 & 10.61 \\
\hline & 4 & 14 & $\mathrm{~A}$ & 1490 & & \\
\hline & & & B & 1361 & 226 & 13.86 \\
\hline & 5 & 14 & $\mathrm{~A}$ & 1174 & 183 & 11.23 \\
\hline & & & B & 908 & & \\
\hline & 6 & 14 & $\mathrm{~A}$ & 1223 & 138 & 8.46 \\
\hline & & & B & 1022 & & \\
\hline & 8 & 14 & $\mathrm{~A}$ & 1250 & 173 & 10.61 \\
\hline & & & B & 1269 & 172 & 10.55 \\
\hline & 9 & 14 & $\mathrm{~A}$ & 1259 & 198 & 12.15 \\
\hline & & & B & 1314 & 221 & 13.56 \\
\hline & 11 & 14 & $\mathrm{~A}$ & 1055 & 63 & 3.86 \\
\hline & & & B & 1082 & 87 & 5.34 \\
\hline & & & $\mathrm{C}$ & 929 & 95 & 5.83 \\
\hline & & & $\mathrm{D}$ & 1107 & 67 & 4.11 \\
\hline & & & $\mathrm{E}$ & 1262 & 120 & 7.36 \\
\hline & 13 & 14 & $\mathrm{~A}$ & 1138 & 140 & 8.59 \\
\hline & & & B & 1046 & 109 & 6.69 \\
\hline & & & $\mathrm{C}$ & 1118 & 148 & 9.08 \\
\hline & & & $\mathrm{D}$ & 982 & 95 & 5.83 \\
\hline & & & $\mathrm{E}$ & 1113 & 152 & 9.32 \\
\hline & & & $\mathrm{F}$ & 1182 & 183 & 11.23 \\
\hline Tank 15 Average & & & & 1164 & 147 & 9.01 \\
\hline 16 & 2 & 14 & $\mathrm{~A}$ & 1233 & 169 & 10.90 \\
\hline $1670 \mathrm{ppm} \mathrm{CO}_{2}$ & 3 & 14 & $\mathrm{~A}$ & 1166 & & \\
\hline \multirow[t]{9}{*}{ Low Light } & 4 & 14 & $\mathrm{~A}$ & 984 & & \\
\hline & 5 & 14 & $\mathrm{~A}$ & 1249 & 104 & 6.71 \\
\hline & & & B & 1244 & 142 & 9.16 \\
\hline & & & $\mathrm{C}$ & 1127 & 112 & 7.22 \\
\hline & 7 & 14 & $\mathrm{~A}$ & 1049 & 86 & 5.54 \\
\hline & & & B & 1405 & 174 & 11.22 \\
\hline & & & $\mathrm{C}$ & 1312 & 152 & 9.80 \\
\hline & 10 & 14 & $\mathrm{~A}$ & 1098 & 104 & 6.71 \\
\hline & & & B & 1314 & 165 & 10.64 \\
\hline
\end{tabular}


2012 skeletal size and weight data, continued

\begin{tabular}{|c|c|c|c|c|c|c|}
\hline $\begin{array}{c}\text { Tank } \\
\text { Treatment }\end{array}$ & Tile ID & $\begin{array}{c}\text { Tile Age } \\
\text { (days) }\end{array}$ & Coralite ID & $\begin{array}{l}\text { Size } \\
(\mu \mathbf{m})\end{array}$ & $\begin{array}{c}\text { Weight } \\
(\mu \mathrm{g})\end{array}$ & $\begin{array}{c}\text { ASN Weight } \\
\left(\mu \mathrm{g} \mathrm{mm}^{-1} \text { day }^{-1}\right)\end{array}$ \\
\hline & & & $\mathrm{C}$ & 1052 & & \\
\hline & & & $\mathrm{D}$ & 1239 & 134 & 8.64 \\
\hline & & & $\mathrm{E}$ & 1290 & 152 & 9.80 \\
\hline & & & $\mathrm{F}$ & 1080 & 91 & 5.87 \\
\hline & & & G & 1266 & 150 & 9.67 \\
\hline & 12 & 14 & $\mathrm{~A}$ & 904 & 156 & 10.06 \\
\hline & & & $\mathrm{B}$ & 889 & 107 & 6.90 \\
\hline & & & $\mathrm{C}$ & 883 & 140 & 9.03 \\
\hline & & & $\mathrm{D}$ & 964 & & \\
\hline & & & $\mathrm{E}$ & 861 & 145 & 9.35 \\
\hline & & & $\mathrm{F}$ & 854 & 109 & 7.03 \\
\hline & & & G & 1067 & 202 & 13.02 \\
\hline & 13 & 14 & $\mathrm{~A}$ & 967 & 85 & 5.48 \\
\hline & & & B & 1037 & 66 & 4.26 \\
\hline & & & $\mathrm{C}$ & 1274 & 141 & 9.09 \\
\hline Tank 16 Average & & & & 1108 & 131 & 8.46 \\
\hline
\end{tabular}

Table B.5: Skeletal size (i.e., septa diameter), Weight (i.e., mass $\mathrm{CaCO}_{3}$ ), and Age-and SizeNormalized (ASN) weight of juvenile Favia fragum from the $2012 \mathrm{CO}_{2} \mathrm{x}$ Light experiment. ASN Weight is the total mass of $\mathrm{CaCO}_{3}$ for the sample divided by the average skeletal size for the tank and the average age of the sample. 


\section{B.6 2012 Coral Tissue Lipid Data}

\begin{tabular}{|c|c|c|c|c|c|}
\hline Specimen & Sample ID & & $\begin{array}{c}\text { Total Lipid } \\
(\mu \mathrm{g})\end{array}$ & $\begin{array}{c}\text { N Lipid } \\
\left(\mu \text { g larvae }^{-1}\right)\end{array}$ & \\
\hline \multirow{18}{*}{ Larvae } & LIP 1 & & 449 & 22.45 & \\
\hline & LIP 2 & & 428 & 21.38 & \\
\hline & LIP 3 & & 424 & 21.18 & \\
\hline & LIP 5 & & 327 & 16.35 & \\
\hline & LIP 6 & & 390 & 19.48 & \\
\hline & LIP 7 & & 538 & 26.90 & \\
\hline & LIP 8 & & 382 & 19.10 & \\
\hline & LIP 9 & & 451 & 22.53 & \\
\hline & LIP 11 & & 493 & 24.63 & \\
\hline & LIP 12 & & 487 & 24.33 & \\
\hline & LIP 13 & & 412 & 20.58 & \\
\hline & LIP 14 & & 375 & 18.75 & \\
\hline & LIP 15 & & 320 & 15.98 & \\
\hline & LIP 16 & & 418 & 20.90 & \\
\hline & LIP 17 & & 427 & 21.33 & \\
\hline & LIP 18 & & 590 & 29.48 & \\
\hline & LIP 19 & & 448 & 22.40 & \\
\hline & LIP 20 & & 442 & 22.10 & \\
\hline Larval Average & & & 433 & 21.66 & \\
\hline $\begin{array}{c}\text { Tank } \\
\text { Treatment }\end{array}$ & Sample ID & $\begin{array}{l}\text { Average Age } \\
\text { (days) }\end{array}$ & $\begin{array}{c}\text { Total Lipid } \\
(\mu \mathrm{g})\end{array}$ & $\begin{array}{c}\text { AN Lipid } \\
\left(\mu \mathrm{g} \mathrm{mm}^{-2} \text { spat }^{-1}\right)\end{array}$ & $\begin{array}{c}\text { AAN Lipid } \\
\left(\mu \mathrm{g} \mathrm{mm}^{-2} \text { day }^{-1} \text { spat }^{-1}\right)\end{array}$ \\
\hline 1 & LIP 21 & 14 & 81 & 8.57 & 0.61 \\
\hline $420 \mathrm{ppm} \mathrm{CO}_{2}$ & LIP 62 & 14 & 144 & 15.18 & 1.08 \\
\hline High Light & LIP 63 & 14 & 202 & 21.32 & 1.52 \\
\hline Tank 1 Average & & & 142 & 15.02 & 1.07 \\
\hline 2 & LIP 22 & 14 & 141 & 15.13 & 1.08 \\
\hline 1670 ppm $\mathrm{CO}_{2}$ & LIP 65 & 14 & 146 & 15.62 & 1.12 \\
\hline \multirow[t]{2}{*}{ High Light } & LIP 66 & 14 & 276 & 29.62 & 2.12 \\
\hline & LIP 67 & 14 & 131 & 14.06 & 1.00 \\
\hline Tank 2 Average & & & 173 & 18.61 & 1.33 \\
\hline 3 & LIP 60 & 14 & 93 & 8.67 & 0.62 \\
\hline 1670 ppm $\mathrm{CO}_{2}$ & LIP 61 & 14 & 160 & 14.86 & 1.06 \\
\hline \multirow[t]{2}{*}{ High Light } & LIP 68 & 14 & 146 & 13.60 & 0.97 \\
\hline & LIP 69 & 14 & 135 & 12.53 & 0.90 \\
\hline Tank 3 Average & & & 133 & 12.42 & 0.89 \\
\hline 4 & LIP 57 & 14 & 73 & 9.47 & 0.68 \\
\hline $420 \mathrm{ppm} \mathrm{CO}_{2}$ & LIP 58 & 14 & 114 & 14.80 & 1.06 \\
\hline High Light & LIP 59 & 14 & 52 & 6.75 & 0.48 \\
\hline
\end{tabular}


2012 lipid data, continued

\begin{tabular}{|c|c|c|c|c|c|}
\hline $\begin{array}{c}\text { Tank } \\
\text { Treatment }\end{array}$ & Sample ID & $\begin{array}{c}\text { Average Age } \\
(\text { days })\end{array}$ & $\begin{array}{c}\text { Total Lipid } \\
(\mu \mathrm{g})\end{array}$ & $\begin{array}{c}\text { AN Lipid } \\
\left(\mu \mathrm{g} \mathrm{mm}^{-2} \text { spat }^{-1}\right)\end{array}$ & $\begin{array}{c}\text { AAN Lipid } \\
\left(\mu \mathbf{g ~ m m}^{-2} \text { day }^{-1} \text { spat }^{-1}\right)\end{array}$ \\
\hline & LIP 70 & 14 & 154 & 19.99 & 1.43 \\
\hline Tank 4 Average & & & 98 & 12.75 & 0.91 \\
\hline 5 & LIP 23 & 14 & 179 & 16.76 & 1.20 \\
\hline $420 \mathrm{ppm} \mathrm{CO}_{2}$ & LIP 54 & 14 & 166 & 15.59 & 1.11 \\
\hline \multirow[t]{2}{*}{ High Light } & LIP 55 & 14 & 157 & 14.70 & 1.05 \\
\hline & LIP 56 & 14 & 147 & 13.76 & 0.98 \\
\hline Tank 5 Average & & & 162 & 15.20 & 1.09 \\
\hline 6 & LIP 52 & 14 & 119 & 10.60 & 0.76 \\
\hline $1670 \mathrm{ppm} \mathrm{CO}_{2}$ & LIP 53 & 14 & 169 & 15.05 & 1.07 \\
\hline High Light & LIP 71 & 14 & 131 & 11.66 & 0.83 \\
\hline Tank 6 Average & & & 140 & 12.44 & 0.89 \\
\hline 7 & LIP 50 & 14 & 143 & 15.36 & 1.10 \\
\hline $\begin{array}{c}1670 \text { ppm } \mathrm{CO}_{2} \\
\text { High Light }\end{array}$ & LIP 72 & 14 & 125 & 13.38 & 0.96 \\
\hline Tank 7 Average & & & 134 & 14.37 & 1.03 \\
\hline 8 & LIP 24 & 14 & 83 & 7.45 & 0.53 \\
\hline $420 \mathrm{ppm} \mathrm{CO}_{2}$ & LIP 44 & 14 & 81 & 7.27 & 0.52 \\
\hline High Light & LIP 48 & 14 & 126 & 11.27 & 0.80 \\
\hline Tank 8 Average & & & 97 & 8.66 & 0.62 \\
\hline 9 & LIP 33 & 14 & 31 & 2.99 & 0.21 \\
\hline $1670 \mathrm{ppm} \mathrm{CO}_{2}$ & LIP 45 & 14 & 20 & 1.93 & 0.14 \\
\hline Low Light & LIP 46 & 14 & 62 & 5.99 & 0.43 \\
\hline Tank 9 Average & & & 38 & 3.64 & 0.26 \\
\hline 11 & LIP 38 & 14 & 48 & 4.17 & 0.30 \\
\hline 420 ppm $\mathrm{CO}_{2}$ & LIP 39 & 14 & 85 & 7.41 & 0.53 \\
\hline \multirow[t]{2}{*}{ Low Light } & LIP 40 & 14 & 86 & 7.50 & 0.54 \\
\hline & LIP 73 & 14 & 32 & 2.76 & 0.20 \\
\hline Tank 11 Average & & & 62 & 5.46 & 0.39 \\
\hline 12 & LIP 31 & 14 & 33 & 2.76 & 0.20 \\
\hline $1670 \mathrm{ppm} \mathrm{CO}_{2}$ & LIP 32 & 14 & 110 & 9.35 & 0.67 \\
\hline \multirow[t]{2}{*}{ Low Light } & LIP 37 & 14 & 56 & 4.72 & 0.34 \\
\hline & LIP 75 & 14 & 36 & 3.06 & 0.22 \\
\hline Tank 12 Average & & & 59 & 4.97 & 0.36 \\
\hline 13 & LIP 35 & 14 & 41 & 4.97 & 0.36 \\
\hline $1670 \mathrm{ppm} \mathrm{CO}_{2}$ & LIP 36 & 14 & 41 & 4.91 & 0.35 \\
\hline Low Light & LIP 74 & 14 & 79 & 9.58 & 0.68 \\
\hline Tank 13 Average & & & 54 & 6.49 & 0.46 \\
\hline 14 & LIP 28 & 14 & 71 & 5.99 & 0.43 \\
\hline $420 \mathrm{ppm} \mathrm{CO}_{2}$ & LIP 29 & 14 & 78 & 6.63 & 0.47 \\
\hline Low Light & LIP 30 & 14 & 39 & 3.31 & 0.24 \\
\hline
\end{tabular}


2012 lipid data, continued

\begin{tabular}{cccccc}
\hline $\begin{array}{c}\text { Tank } \\
\text { Treatment }\end{array}$ & Sample ID & $\begin{array}{c}\text { Average Age } \\
(\text { days })\end{array}$ & $\begin{array}{c}\text { Total Lipid } \\
(\mu \mathbf{g})\end{array}$ & $\begin{array}{c}\text { AN Lipid } \\
\left(\mu \mathbf{~ m m}^{-2} \mathbf{s p a t}^{-1}\right)\end{array}$ & $\begin{array}{c}\text { AAN Lipid } \\
\left(\mu \mathbf{~ m m}^{-2} \mathbf{d a y}^{-1} \mathbf{s p a t}^{-1}\right)\end{array}$ \\
\hline LIP 41 & 14 & 86 & 7.26 & 0.52 \\
\hline Tank 14 Average & & & 68 & 5.80 & 0.41 \\
\hline 15 & LIP 43 & 14 & 60 & 5.63 & 0.40 \\
Low Light & & & & & 0.40 \\
\hline Tank 15 Average & & & 60 & 5.63 & 0.61 \\
\hline 16 & LIP 25 & 14 & 83 & 8.56 & 0.64 \\
1670 ppm CO 2 & LIP 26 & 14 & 86 & 8.92 & 0.59 \\
Low Light & LIP 27 & 14 & 79 & 8.19 & 0.61 \\
\hline Tank 16 Average & & 83 & 8.56 & \\
\hline \hline
\end{tabular}

Table B.6: Reporting total lipid weight, Area-Normalized (AN) lipid weight and Age- and Area- Normalized (AAN) lipid weight. AN Lipid is the total mass of lipid measured for a given sample divided by the number of specimens in that sample and the circular area defined by the average skeletal size (i.e., septa diameter) for the sampled tank (derived from Appendix B.5). AAN Lipid is AN Lipid divided by the average age of the sample. Lipid samples typically contain 10 corallites (20 larvae). 


\section{B.7 2012 Symbiont Density Data}

\begin{tabular}{|c|c|c|c|c|c|}
\hline $\begin{array}{c}\text { Tank } \\
\text { Treatment }\end{array}$ & Sample ID & $\begin{array}{c}\text { Average Age } \\
(\text { days })\end{array}$ & $\begin{array}{c}\text { Symbionts } \\
(\text { cells })\end{array}$ & $\begin{array}{c}\text { AN Symbionts } \\
\left(\times 10^{3} \text { cells }\right. \\
\left.\text { mm }^{-2} \text { spat }^{-1}\right)\end{array}$ & $\begin{array}{c}\text { AAN Symbionts } \\
\left(\times 10^{3} \text { cells }\right. \\
\left.\text { mm }^{-2} \text { day }^{-1} \text { spat }^{-1}\right)\end{array}$ \\
\hline 1 & ZOOX 49 & 14 & 5.0 & 2.64 & 0.19 \\
\hline $420 \mathrm{ppm} \mathrm{CO}_{2}$ & ZOOX 50 & 14 & 8.2 & 4.34 & 0.31 \\
\hline \multirow[t]{3}{*}{ High Light } & ZOOX 51 & 14 & 5.3 & 2.80 & 0.20 \\
\hline & ZOOX 53 & 14 & 3.7 & 1.96 & 0.14 \\
\hline & ZOOX 72 & 14 & 8.1 & 4.26 & 0.30 \\
\hline Tank 1 Average & & & 6.1 & 3.20 & 0.23 \\
\hline 2 & ZOOX 52 & 14 & 14.7 & 7.88 & 0.56 \\
\hline $1670 \mathrm{ppm} \mathrm{CO}_{2}$ & ZOOX 55 & 14 & 13.9 & 7.48 & 0.53 \\
\hline \multirow[t]{3}{*}{ High Light } & ZOOX 56 & 14 & 23.4 & 12.54 & 0.90 \\
\hline & ZOOX 57 & 14 & 4.0 & 2.15 & 0.15 \\
\hline & ZOOX 73 & 14 & 18.6 & 9.99 & 0.71 \\
\hline Tank 2 Average & & & 14.9 & 8.01 & 0.57 \\
\hline 3 & ZOOX 1 & 14 & 13.6 & 6.35 & 0.45 \\
\hline $1670 \mathrm{ppm} \mathrm{CO}_{2}$ & ZOOX 44 & 14 & 12.3 & 5.73 & 0.41 \\
\hline \multirow[t]{3}{*}{ High Light } & ZOOX 45 & 14 & 11.4 & 5.33 & 0.38 \\
\hline & ZOOX 46 & 14 & 9.7 & 4.50 & 0.32 \\
\hline & ZOOX 54 & 15 & 12.0 & 5.59 & 0.37 \\
\hline Tank 3 Average & & & 11.8 & 5.50 & 0.39 \\
\hline 4 & ZOOX 2 & 14 & 7.3 & 4.74 & 0.34 \\
\hline $420 \mathrm{ppm} \mathrm{CO}_{2}$ & ZOOX 3 & 14 & 10.7 & 6.91 & 0.49 \\
\hline \multirow[t]{3}{*}{ High Light } & ZOOX 43 & 14 & 22.8 & 14.80 & 1.06 \\
\hline & ZOOX 47 & 14 & 9.8 & 6.33 & 0.45 \\
\hline & ZOOX 48 & 14 & 9.3 & 6.04 & 0.43 \\
\hline Tank 4 Average & & & 12.0 & 7.76 & 0.55 \\
\hline 5 & ZOOX 37 & 14 & 11.7 & 5.47 & 0.39 \\
\hline \multirow[t]{2}{*}{$420 \mathrm{ppm} \mathrm{CO}_{2}$} & ZOOX 38 & 14 & 10.9 & 5.10 & 0.36 \\
\hline & ZOOX 39 & 14 & 9.2 & 4.30 & 0.31 \\
\hline \multirow[t]{2}{*}{ High Light } & ZOOX 40 & 14 & 9.8 & 4.58 & 0.33 \\
\hline & ZOOX 41 & 14 & 12.8 & 6.01 & 0.43 \\
\hline Tank 5 Average & & & 10.8 & 5.09 & 0.36 \\
\hline 6 & ZOOX 4 & 14 & 1.3 & 0.56 & 0.04 \\
\hline $1670 \mathrm{ppm} \mathrm{CO}_{2}$ & ZOOX 5 & 14 & 16.8 & 7.46 & 0.53 \\
\hline High Light & ZOOX 6 & 14 & 14.4 & 6.41 & 0.46 \\
\hline
\end{tabular}


2012 symbiont data, continued

\begin{tabular}{|c|c|c|c|c|c|}
\hline $\begin{array}{c}\text { Tank } \\
\text { Treatment }\end{array}$ & Sample ID & $\begin{array}{c}\text { Average Age } \\
\quad(\text { days })\end{array}$ & $\begin{array}{c}\text { Symbionts } \\
\text { (cells) }\end{array}$ & $\begin{array}{c}\text { AN Symbionts } \\
\left(\times 10^{3} \text { cells }\right. \\
\left.\text { mm }^{-2} \text { spat }^{-1}\right)\end{array}$ & $\begin{array}{c}\text { AAN Symbionts } \\
\left(\times 10^{3} \text { cells }\right. \\
\left.\text { mm }^{-2} \text { day }^{-1} \text { spat }^{-1}\right)\end{array}$ \\
\hline & ZOOX 42 & 14 & 10.8 & 4.81 & 0.34 \\
\hline & ZOOX 74 & 14 & 22.0 & 9.80 & 0.70 \\
\hline Tank 6 Average & & & 13.0 & 5.81 & 0.41 \\
\hline 7 & ZOOX 27 & 14 & 22.1 & 11.85 & 0.85 \\
\hline $1670 \mathrm{ppm} \mathrm{CO}_{2}$ & ZOOX 35 & 14 & 12.5 & 6.71 & 0.48 \\
\hline \multirow[t]{3}{*}{ High Light } & ZOOX 36 & 14 & 11.0 & 5.91 & 0.42 \\
\hline & ZOOX 58 & 14 & 14.2 & 7.60 & 0.54 \\
\hline & ZOOX 59 & 14 & 7.2 & 3.86 & 0.28 \\
\hline Tank 7 Average & & & 13.4 & 7.19 & 0.51 \\
\hline 8 & ZOOX 8 & 14 & 33.4 & 14.99 & 1.07 \\
\hline $420 \mathrm{ppm} \mathrm{CO}_{2}$ & ZOOX 33 & 14 & 10.8 & 4.83 & 0.34 \\
\hline \multirow[t]{3}{*}{ High Light } & ZOOX 62 & 14 & 19.1 & 8.58 & 0.61 \\
\hline & ZOOX 63 & 14 & 11.2 & 5.00 & 0.36 \\
\hline & ZOOX 64 & 14 & 10.8 & 4.83 & 0.34 \\
\hline Tank 8 Average & & & 17.0 & 7.65 & 0.55 \\
\hline 9 & ZOOX 7 & 14 & 4.9 & 2.34 & 0.17 \\
\hline $1670 \mathrm{ppm} \mathrm{CO}_{2}$ & ZOOX 31 & 14 & 24.6 & 11.86 & 0.85 \\
\hline \multirow[t]{3}{*}{ Low Light } & ZOOX 34 & 14 & 5.4 & 2.61 & 0.19 \\
\hline & ZOOX 60 & 14 & 28.0 & 13.52 & 0.97 \\
\hline & ZOOX 61 & 14 & 5.0 & 2.39 & 0.17 \\
\hline Tank 9 Average & & & 13.6 & 6.54 & 0.47 \\
\hline 11 & ZOOX 24 & 14 & 32.5 & 14.26 & 1.02 \\
\hline $420 \mathrm{ppm} \mathrm{CO}_{2}$ & ZOOX 25 & 14 & 23.6 & 10.36 & 0.74 \\
\hline \multirow[t]{2}{*}{ Low Light } & ZOOX 26 & 14 & 15.5 & 6.78 & 0.48 \\
\hline & ZOOX 32 & 14 & 16.1 & 7.05 & 0.50 \\
\hline Tank 11 Average & & & 21.9 & 9.61 & 0.69 \\
\hline 12 & ZOOX 10 & 14 & 17.1 & 7.24 & 0.52 \\
\hline $1670 \mathrm{ppm} \mathrm{CO}_{2}$ & ZOOX 13 & 14 & 23.6 & 10.01 & 0.71 \\
\hline \multirow[t]{3}{*}{ Low Light } & ZOOX 21 & 14 & 17.9 & 7.58 & 0.54 \\
\hline & ZOOX 22 & 14 & 16.4 & 6.97 & 0.50 \\
\hline & ZOOX 23 & 14 & 6.1 & 2.57 & 0.18 \\
\hline Tank 12 Average & & & 16.2 & 6.88 & 0.49 \\
\hline 13 & ZOOX 9 & 14 & 18.1 & 10.95 & 0.78 \\
\hline $1670 \mathrm{ppm} \mathrm{CO}_{2}$ & ZOOX 12 & 14 & 30.4 & 18.44 & 1.32 \\
\hline \multirow[t]{5}{*}{ Low Light } & ZOOX 28 & 14 & 21.9 & 13.25 & 0.95 \\
\hline & ZOOX 29 & 14 & 15.5 & 9.37 & 0.67 \\
\hline & ZOOX 30 & 14 & 17.7 & 10.71 & 0.76 \\
\hline & ZOOX 65 & 14 & 4.4 & 2.65 & 0.19 \\
\hline & ZOOX 75 & 14 & 5.9 & 3.55 & 0.25 \\
\hline Tank 13 Average & & & 16.2 & 9.85 & 0.70 \\
\hline
\end{tabular}


2012 symbiont data, continued

\begin{tabular}{|c|c|c|c|c|c|}
\hline $\begin{array}{c}\text { Tank } \\
\text { Treatment }\end{array}$ & Sample ID & $\begin{array}{c}\text { Average Age } \\
\text { (days) }\end{array}$ & $\begin{array}{c}\text { Symbionts } \\
\text { (cells) }\end{array}$ & $\begin{array}{c}\text { AN Symbionts } \\
\left(\times 10^{3} \text { cells }\right. \\
\left.\text { mm }^{-2} \text { spat }^{-1}\right)\end{array}$ & $\begin{array}{c}\text { AAN Symbionts } \\
\left(\times 10^{3} \text { cells }\right. \\
\left.\text { mm }^{-2} \text { day }^{-1} \text { spat }^{-1}\right)\end{array}$ \\
\hline 14 & ZOOX 11 & 14 & 4.9 & 2.08 & 0.15 \\
\hline $420 \mathrm{ppm} \mathrm{CO}_{2}$ & ZOOX 18 & 14 & 3.6 & 1.51 & 0.11 \\
\hline \multirow[t]{4}{*}{ Low Light } & ZOOX 19 & 14 & 4.3 & 1.82 & 0.13 \\
\hline & ZOOX 20 & 14 & 13.5 & 5.73 & 0.41 \\
\hline & ZOOX 69 & 14 & 8.3 & 3.53 & 0.25 \\
\hline & ZOOX 70 & 14 & 18.9 & 8.03 & 0.57 \\
\hline Tank 14 Average & & & 8.9 & 3.78 & 0.27 \\
\hline 15 & ZOOX 14 & 14 & 32.3 & 15.14 & 1.08 \\
\hline $420 \mathrm{ppm} \mathrm{CO}_{2}$ & ZOOX 15 & 14 & 9.7 & 4.53 & 0.32 \\
\hline \multirow[t]{3}{*}{ Low Light } & ZOOX 16 & 14 & 3.1 & 1.46 & 0.10 \\
\hline & ZOOX 76 & 14 & 10.5 & 4.91 & 0.35 \\
\hline & ZOOX 77 & 14 & 6.5 & 3.05 & 0.22 \\
\hline Tank 15 Average & & & 12.4 & 5.82 & 0.42 \\
\hline 16 & ZOOX 17 & 14 & 28.4 & 14.70 & 1.05 \\
\hline $1670 \mathrm{ppm} \mathrm{CO}_{2}$ & ZOOX 66 & 14 & 19.3 & 9.98 & 0.71 \\
\hline \multirow[t]{3}{*}{ Low Light } & ZOOX 67 & 14 & 26.1 & 13.51 & 0.97 \\
\hline & ZOOX 68 & 14 & 5.3 & 2.72 & 0.19 \\
\hline & ZOOX 78 & 14 & 12.3 & 6.35 & 0.45 \\
\hline Tank 16 Average & & & 18.2 & 9.46 & 0.68 \\
\hline
\end{tabular}

Table B.7: Symbiont count, Area-Normalized (AN) Symbiont density, and Area- and AgeNormalized (AAN) Symbiont density for the $2012 \mathrm{CO}_{2} \mathrm{x}$ Light experiment. Symbionts is the average number of zooxanthellae cells counted in the hemacytometer grid, AN Symbiont Lipid is the total symbiont density for the sample divided by the number of specimens in that sample (1) and the circular area defined by the average skeletal size (i.e., septa diameter) for the tank (derived from Appendix B.5), and AAN Symbionts is AN Symbionts divided by the average age of the sample. 


\section{B.8 2012 Pigment Data}

\begin{tabular}{|c|c|c|c|c|c|}
\hline $\begin{array}{c}\text { Tank } \\
\text { Treatment }\end{array}$ & Sample ID & $\begin{array}{l}\text { Average Age } \\
\quad(\text { days })\end{array}$ & $\begin{array}{l}\text { Pigment } \\
\qquad(\text { ng } c h l a)\end{array}$ & $\begin{array}{l}\text { AN Pigment } \\
\quad(\text { ng chl a } \\
\left.\text { mm }^{-2} \text { spat }^{-1}\right)\end{array}$ & $\begin{array}{c}\text { AANPigment } \\
(\mathrm{ng} \text { chl } a \\
\left.\mathrm{mm}^{-2} \mathrm{day}^{-1} \text { spat }^{-1}\right)\end{array}$ \\
\hline 1 & RNA 29 & 14 & 65.14 & 13.78 & 0.98 \\
\hline $420 \mathrm{ppm} \mathrm{CO}_{2}$ & RNA 45 & 14 & 0.00 & 0.00 & 0.00 \\
\hline High Light & & 14 & & & \\
\hline Tank 1 Average & & & 32.57 & 6.89 & 0.49 \\
\hline 2 & RNA 28 & 14 & 52.65 & 11.30 & 0.81 \\
\hline $1670 \mathrm{ppm} \mathrm{CO}_{2}$ & RNA 30 & 14 & 0.00 & 0.00 & 0.00 \\
\hline High Light & RNA 31 & 14 & 0.00 & 0.00 & 0.00 \\
\hline Tank 2 Average & & & 17.55 & 3.77 & 0.27 \\
\hline 3 & RNA 25 & 14 & 0.00 & 0.00 & 0.00 \\
\hline $\begin{array}{c}1670 \text { ppm } \mathrm{CO}_{2} \\
\text { High Light }\end{array}$ & RNA 41 & 14 & 0.00 & 0.00 & 0.00 \\
\hline Tank 3 Average & & & 0.00 & 0.00 & 0.00 \\
\hline \multicolumn{6}{|l|}{$\begin{array}{c}420 \text { ppm } \mathrm{CO}_{2} \\
\text { High Light }\end{array}$} \\
\hline Tank 4 Average & & & 0.00 & 0.00 & 0.00 \\
\hline 5 & RNA 23 & 14 & 73.74 & 13.85 & 0.99 \\
\hline $420 \mathrm{ppm} \mathrm{CO}_{2}$ & RNA 24 & 14 & 0.00 & 0.00 & 0.00 \\
\hline & RNA 33 & 14 & 0.00 & 0.00 & 0.00 \\
\hline High Light & RNA 33 & 14 & 148.75 & 27.94 & 2.00 \\
\hline Tank 5 Average & & & 55.62 & 10.45 & 0.75 \\
\hline 6 & RNA 22 & 14 & 8.27 & 1.47 & 0.11 \\
\hline $1670 \mathrm{ppm} \mathrm{CO}_{2}$ & RNA 32 & 14 & 0.00 & 0.00 & 0.00 \\
\hline High Light & RNA 43 & 14 & 0.00 & 0.00 & 0.00 \\
\hline Tank 6 Average & & & 2.76 & 0.49 & 0.04 \\
\hline 7 & RNA 18 & 14 & 121.31 & 26.06 & 1.86 \\
\hline $1670 \mathrm{ppm} \mathrm{CO}_{2}$ & RNA 20 & 14 & 0.00 & 0.00 & 0.00 \\
\hline High Light & RNA 21 & 14 & 60.01 & 12.89 & 0.92 \\
\hline Tank 7 Average & & & 60.44 & 12.99 & 0.93 \\
\hline 8 & RNA 19 & 14 & 16.55 & 2.97 & 0.21 \\
\hline $420 \mathrm{ppm} \mathrm{CO}_{2}$ & RNA 35 & 14 & 0.00 & 0.00 & 0.00 \\
\hline High Light & RNA 36 & 14 & 0.00 & 0.00 & 0.00 \\
\hline Tank 8 Average & & & 5.52 & 0.99 & 0.07 \\
\hline
\end{tabular}


2012 pigment data, continued

\begin{tabular}{|c|c|c|c|c|c|}
\hline $\begin{array}{c}\text { Tank } \\
\text { Treatment }\end{array}$ & Sample ID & $\begin{array}{c}\text { Average Age } \\
(\text { days })\end{array}$ & $\begin{array}{l}\text { Pigment } \\
\qquad(\text { ng } c h l a)\end{array}$ & $\begin{array}{l}\text { AN Pigment } \\
\quad(\text { ng } \text { chl a } \\
\left.\text { mm }^{-2} \text { spat }^{-1}\right)\end{array}$ & $\begin{array}{c}\text { AANPigment } \\
(\mathrm{ng} \text { chl a } \\
\left.\text { mm }^{-2} \text { day }^{-1} \text { spat }^{-1}\right)\end{array}$ \\
\hline 9 & RNA 16 & 14 & 89.45 & 17.28 & 1.23 \\
\hline $1670 \mathrm{ppm} \mathrm{CO}_{2}$ & RNA 17 & 14 & 29.20 & 5.64 & 0.40 \\
\hline Low Light & RNA 34 & 14 & 0.00 & 0.00 & 0.00 \\
\hline Tank 9 Average & & & 39.55 & 7.64 & 0.55 \\
\hline 11 & RNA 3 & 14 & 94.13 & 16.51 & 1.18 \\
\hline $420 \mathrm{ppm} \mathrm{CO}_{2}$ & RNA 13 & 14 & 80.44 & 14.11 & 1.01 \\
\hline Low Light & RNA 15 & 14 & 108.16 & 18.98 & 1.36 \\
\hline Tank 11 Average & & & 94.24 & 16.53 & 1.18 \\
\hline 12 & RNA 7 & 14 & 165.45 & 28.12 & 2.01 \\
\hline $1670 \mathrm{ppm} \mathrm{CO}_{2}$ & RNA 37 & 14 & 64.56 & 10.97 & 0.78 \\
\hline Low Light & RNA 44 & 14 & 72.79 & 12.37 & 0.88 \\
\hline Tank 12 Average & & & 100.93 & 17.16 & 1.23 \\
\hline 13 & RNA 12 & 14 & 68.21 & 16.55 & 1.18 \\
\hline $1670 \mathrm{ppm} \mathrm{CO}_{2}$ & RNA 14 & 14 & 41.91 & 10.17 & 0.73 \\
\hline Low Light & RNA 46 & 14 & 28.92 & 7.02 & 0.50 \\
\hline Tank 13 Average & & & 46.35 & 11.24 & 0.80 \\
\hline 14 & RNA 4 & 14 & 158.11 & 26.86 & 1.92 \\
\hline $420 \mathrm{ppm} \mathrm{CO}_{2}$ & RNA 9 & 14 & 83.26 & 14.15 & 1.01 \\
\hline Low Light & RNA 11 & 14 & 68.48 & 11.64 & 0.83 \\
\hline Tank 14 Average & & & 103.28 & 17.55 & 1.25 \\
\hline 15 & RNA 5 & 14 & 129.87 & 24.39 & 1.74 \\
\hline $420 \mathrm{ppm} \mathrm{CO}_{2}$ & RNA 6 & 14 & 77.03 & 14.47 & 1.03 \\
\hline Low Light & RNA 38 & 14 & 36.31 & 6.82 & 0.49 \\
\hline Tank 15 Average & & & 81.07 & 15.22 & 1.09 \\
\hline 16 & RNA 8 & 14 & 50.35 & 10.45 & 0.75 \\
\hline $1670 \mathrm{ppm} \mathrm{CO}_{2}$ & RNA 39 & 14 & 43.70 & 9.07 & 0.65 \\
\hline Low Light & RNA 40 & 14 & 0.00 & 0.00 & 0.00 \\
\hline Tank 16 Average & & & 31.35 & 6.50 & 0.46 \\
\hline
\end{tabular}

Table B.8: Pigment mass, Area-Normalized (AN) Pigment density, and Area- and AgeNormalized (AAN) Pigment density for the $2012 \mathrm{CO}_{2} \times$ Light experiment. Pigment is the total mass chl $a$ in the sample, AN Pigment is the total pigment mass for the sample divided by the number of specimens in that sample (5) and the circular area defined by the average skeletal size (i.e., septa diameter) for the tank (derived from Appendix B.5), and AAN Pigment is AN Pigment divided by the average age of the sample. 


\section{B.9 Chapter 4 Statistical Analyses}

\section{B.9.1 Skeletal Size Comparison of 2011/2012 Unfed Corals}

\begin{tabular}{l|ccc|cc}
\hline \hline & & & & \multicolumn{2}{|c}{ t-test } \\
Group & N & Mean & Standard Deviation & df & $\boldsymbol{p}$ \\
\hline 2011 & 12 & 1.280 & 0.116 & 25 & $<0.001$ \\
2012 & 15 & 1.139 & 0.071 & & \\
\hline \hline
\end{tabular}

Results from t-test comparing skeletal size of 2011/2012 unfed corals. Table reports N (sample size), standard deviation of each group, df (degrees of freedom), and MS (mean sum of squares), F (F statistic) and p (significance level) for indicated sources.

\section{B.9.2 2011 Skeletal Size Analysis}

\begin{tabular}{l|cccc}
\hline \hline Source & df & MS & $\boldsymbol{F}$ & $\boldsymbol{p}$ \\
\hline Feeding & 1 & 1.321 & 41.032 & $<0.001$ \\
$\mathrm{CO}_{2}$ & 3 & 0.008 & 0.235 & 0.871 \\
$\mathrm{CO}_{2}$ x Feeding & 3 & 0.049 & 1.511 & 0.250 \\
Error & 16 & 0.032 & & \\
\hline \hline
\end{tabular}

Two-way ANOVA results for for 2011 skeletal size. Table reports df (degrees of freedom), and MS (mean sum of squares), $F$ (F statistic) and $p$ (significance level) for indicated sources.

\section{B.9.3 2011 Skeletal Weight Analysis}

\begin{tabular}{l|cccc}
\hline \hline Source & df & MS & $\boldsymbol{F}$ & $\boldsymbol{p}$ \\
\hline Feeding & 1 & 31.808 & 16.265 & $<0.001$ \\
$\mathrm{CO}_{2}$ & 3 & 8.498 & 4.346 & 0.020 \\
$\mathrm{CO}_{2}$ x Feeding & 3 & 2.510 & 1.283 & 0.314 \\
Error & 16 & 1.956 & & \\
\hline \hline
\end{tabular}

Two-way ANOVA results for 2011 age- and size-normalized skeletal weight. Table reports $\mathrm{df}$ (degrees of freedom), and MS (mean sum of squares), $F$ (F statistic) and $p$ (significance level) for indicated sources. 


\section{B.9.4 2012 Skeletal Size Analysis}

\begin{tabular}{l|cccc}
\hline \hline Source & df & MS & $\boldsymbol{F}$ & $\boldsymbol{p}$ \\
\hline Light & 1 & $5.560 \mathrm{E}-3$ & 1.099 & 0.317 \\
$\mathrm{CO}_{2}$ & 1 & $2.013 \mathrm{E}-3$ & 0.398 & 0.541 \\
$\mathrm{CO}_{2} \times$ Light & 1 & $8.611 \mathrm{E}-3$ & 1.702 & 0.219 \\
Error & 11 & $5.059 \mathrm{E}-3$ & & \\
\hline \hline
\end{tabular}

Two-way ANOVA results for 2012 skeletal size. Table reports df (degrees of freedom), and MS (mean sum of squares), $F$ (F statistic) and $p$ (significance level) for indicated sources.

\section{B.9.5 2012 Skeletal Weight Analysis}

\begin{tabular}{l|cccc}
\hline \hline Source & df & MS & $\boldsymbol{F}$ & $\boldsymbol{p}$ \\
\hline Light & 1 & 0.955 & 0.623 & 0.447 \\
$\mathrm{CO}_{2}$ & 1 & 10.260 & 6.697 & 0.025 \\
$\mathrm{CO}_{2}$ x Light & 1 & 0.083 & 0.054 & 0.820 \\
Error & 11 & 1.532 & & \\
\hline \hline
\end{tabular}

Two-way ANOVA results for 2012 age- and size-normalized skeletal weight. Table reports df (degrees of freedom), and MS (mean sum of squares), $F$ (F statistic) and $p$ (significance level) for indicated sources.

\section{B.9.6 Inter-year, (Low Light) Skeletal Weight Comparison}

\begin{tabular}{l|cccc}
\hline \hline Source & df & MS & $\boldsymbol{F}$ & $\boldsymbol{p}$ \\
\hline Year & 1 & 11.876 & 13.829 & 0.005 \\
$\mathrm{CO}_{2}$ & 1 & 16.699 & 19.445 & 0.002 \\
$\mathrm{CO}_{2}$ x Year & 1 & 0.699 & 0.814 & 0.391 \\
Error & 9 & 0.859 & & \\
\hline \hline
\end{tabular}

Two-way ANOVA results for 2010/2012 skeletal weight. Table reports df (degrees of freedom), and MS (mean sum of squares), $F$ (F statistic) and $p$ (significance level) for indicated sources. 


\section{B.9.7 Inter-year, (High Light) Skeletal Weight Comparison}

\begin{tabular}{l|cccc}
\hline \hline Source & df & MS & $\boldsymbol{F}$ & $\boldsymbol{p}$ \\
\hline Year & 1 & 0.596 & 0.376 & 0.554 \\
$\mathrm{CO}_{2}$ & 1 & 9.348 & 5.895 & 0.036 \\
$\mathrm{CO}_{2}$ x Year & 1 & 0.062 & 0.039 & 0.847 \\
Error & 10 & 1.586 & & \\
\hline \hline
\end{tabular}

Two-way ANOVA results for 2011/2012 age- and size-normalized skeletal weight. Table reports df (degrees of freedom), and MS (mean sum of squares), $F$ (F statistic) and $p$ (significance level) for indicated sources.

\section{B.9.8 2012 Total Lipid Comparison}

\begin{tabular}{l|cccc}
\hline \hline Source & df & MS & $\boldsymbol{F}$ & $\boldsymbol{p}$ \\
\hline Light & 1 & 8.118 & 28.296 & $<0.001$ \\
$\mathrm{CO}_{2}$ & 1 & $3.67 \mathrm{E}-4$ & $1.279 \mathrm{E}-3$ & 0.972 \\
$\mathrm{CO}_{2} \times$ Light & 1 & 0.069 & 0.241 & 0.633 \\
Error & 11 & 0.287 & & \\
\hline \hline
\end{tabular}

Two-way ANOVA results for 2012 age- and area-normalized total lipid. Data were -1/x transformed in order to homogenize variances prior to analyses. Table reports df (degrees of freedom), and MS (mean sum of squares), $F$ (F statistic) and $p$ (significance level) for indicated sources.

\section{B.9.9 2012 Symbiont Density Comparison}

\begin{tabular}{l|cccc}
\hline \hline Source & df & MS & $\boldsymbol{F}$ & $\boldsymbol{p}$ \\
\hline Light & 1 & $19.820 \mathrm{E} 3$ & 0.948 & 0.351 \\
$\mathrm{CO}_{2}$ & 1 & $28.450 \mathrm{E} 3$ & 1.361 & 0.268 \\
$\mathrm{CO}_{2} \times$ Light & 1 & $5.638 \mathrm{E} 3$ & 0.270 & 0.614 \\
Error & 11 & $20.899 \mathrm{E} 3$ & & \\
\hline \hline
\end{tabular}

Two-way ANOVA results for 2012 age- and area-normalized symbiont density. Table reports df (degrees of freedom), and MS (mean sum of squares), $F$ (F statistic) and $p$ (significance level) for indicated sources. 


\section{B.9.10 2012 Pigment Comparison}

\begin{tabular}{l|cccc}
\hline \hline Source & df & MS & $\boldsymbol{F}$ & $\boldsymbol{p}$ \\
\hline Light & 1 & 1.556 & 13.211 & 0.004 \\
$\mathrm{CO}_{2}$ & 1 & 0.174 & 1.474 & 0.250 \\
$\mathrm{CO}_{2} \times$ Light & 1 & 0.144 & 1.222 & 0.293 \\
Error & 11 & 0.118 & & \\
\hline \hline
\end{tabular}

Two-way ANOVA results for 2012 age- and area-normalized pigment density. Table reports df (degrees of freedom), and MS (mean sum of squares), $F$ (F statistic) and $p$ (significance level) for indicated sources.

\section{B.9.11 Inter-year, (Low Light) Total Lipid Comparison}

\begin{tabular}{l|cccc}
\hline \hline Source & df & MS & $\boldsymbol{F}$ & $\boldsymbol{p}$ \\
\hline Year & 1 & 1.841 & 5.842 & 0.039 \\
$\mathrm{CO}_{2}$ & 1 & 0.062 & 0.196 & 0.668 \\
$\mathrm{CO}_{2}$ x Year & 1 & $4.82 \mathrm{E}-4$ & $1.531 \mathrm{E}-3$ & 0.970 \\
Error & 9 & 0.315 & & \\
\hline \hline
\end{tabular}

Two-way ANOVA results for 2010/2012 age- and area-normalized total lipid. Data were -1/x transformed in order to homogenize variances prior to analyses. Table reports df (degrees of freedom), and MS (mean sum of squares), $F$ (F statistic) and $p$ (significance level) for indicated sources.

\section{B.9.12 Inter-year, (High Light) Total Lipid Comparison}

\begin{tabular}{l|cccc}
\hline \hline Source & df & MS & $\boldsymbol{F}$ & $\boldsymbol{p}$ \\
\hline Year & 1 & 0.011 & 0.103 & 0.755 \\
$\mathrm{CO}_{2}$ & 1 & 0.006 & 0.056 & 0.817 \\
$\mathrm{CO}_{2} \times$ Year & 1 & 0.038 & 0.357 & 0.564 \\
Error & 10 & 0.106 & & \\
\hline \hline
\end{tabular}

Two-way ANOVA results for 2011/2012 age- and area-normalized total lipid. Data were -1/x transformed in order to homogenize variances prior to analyses. Table reports df (degrees of freedom), and MS (mean sum of squares), $F$ (F statistic) and $p$ (significance level) for indicated sources 


\section{B.9.13 Inter-year, (Low Light) Symbiont Density Comparison}

\begin{tabular}{l|cccc}
\hline \hline Source & df & MS & $\boldsymbol{F}$ & $\boldsymbol{p}$ \\
\hline Year & 1 & $4.818 \mathrm{E} 5$ & 11.074 & 0.009 \\
$\mathrm{CO}_{2}$ & 1 & $2.561 \mathrm{E} 5$ & 5.886 & 0.038 \\
$\mathrm{CO}_{2}$ x Year & 1 & $7.792 \mathrm{E} 4$ & 1.791 & 0.214 \\
Error & 9 & $4.351 \mathrm{E} 4$ & & \\
\hline \hline
\end{tabular}

Two-way ANOVA results for 2010/2012 age- and area-normalized symbiont density. Table reports df (degrees of freedom), and MS (mean sum of squares), $F$ (F statistic) and $p$ (significance level) for indicated sources.

\section{B.9.14 Inter-year, (High Light) Symbiont Density Comparison}

\begin{tabular}{l|cccc}
\hline \hline Source & df & MS & $\boldsymbol{F}$ & $\boldsymbol{p}$ \\
\hline Year & 1 & $2.272 \mathrm{E} 4$ & 1.104 & 0.318 \\
$\mathrm{CO}_{2}$ & 1 & $1.735 \mathrm{E} 2$ & $8.430 \mathrm{E} 3$ & 0.929 \\
$\mathrm{CO}_{2} \times$ Year & 1 & $5.931 \mathrm{E} 3$ & 0.288 & 0.603 \\
Error & 10 & $2.058 \mathrm{E} 4$ & & \\
\hline \hline
\end{tabular}

Two-way ANOVA results for 2011/2012 age- and area-normalized symbiont density. Table reports df (degrees of freedom), and MS (mean sum of squares), $F$ (F statistic) and $p$ (significance level) for indicated sources.

\section{B.9.15 Inter-year, (Low Light) Pigment Comparison}

\begin{tabular}{l|cccc}
\hline \hline Source & df & MS & $\boldsymbol{F}$ & $\boldsymbol{p}$ \\
\hline Year & 1 & 0.216 & 3.753 & 0.085 \\
$\mathrm{CO}_{2}$ & 1 & 0.440 & 7.639 & 0.022 \\
$\mathrm{CO}_{2}$ x Year & 1 & 0.006 & 0.105 & 0.753 \\
Error & 9 & 0.058 & & \\
\hline \hline
\end{tabular}

Two-way ANOVA results for 2010/2012 age- and area-normalized pigment density. Table reports df (degrees of freedom), and MS (mean sum of squares), $F$ (F statistic) and $p$ (significance level) for indicated sources. 


\section{B.9.16 Inter-year, (High Light) Pigment Comparison}

\begin{tabular}{l|cccc}
\hline \hline Source & df & MS & $\boldsymbol{F}$ & $\boldsymbol{p}$ \\
\hline Year & 1 & 0.767 & 4.506 & 0.060 \\
$\mathrm{CO}_{2}$ & 1 & 0.026 & 0.150 & 0.706 \\
$\mathrm{CO}_{2}$ x Year & 1 & 0.015 & 0.090 & 0.770 \\
Error & 10 & 0.170 & & \\
\hline \hline
\end{tabular}

Two-way ANOVA results for 2011/2012 age- and area-normalized pigment density. Table reports df (degrees of freedom), and MS (mean sum of squares), $F$ (F statistic) and $p$ (significance level) for indicated sources. 


\section{Appendix C}

\section{Data for Chapter 5}

\section{C.1 Tissue Thickness of Equatorial Pacific Coral Core Samples}

\begin{tabular}{|c|c|c|c|}
\hline Coral ID & $\begin{array}{c}\text { Tissue Thicnkness } \\
\text { ( } \mathrm{mm})\end{array}$ & Coral ID & $\begin{array}{l}\text { Thicnkness } \\
(\mathrm{mm})\end{array}$ \\
\hline \multicolumn{2}{|c|}{ West Jarvis } & \multicolumn{2}{|c|}{ East Jarvis } \\
\hline Short Core A1 & 6.87 & Short Core A & 7.96 \\
\hline Short Core A2 & 8.08 & Short Core B & 6.13 \\
\hline Short Core B & 9.28 & Short Core C & 6.29 \\
\hline Short Core C & 8.00 & Short Core D & 8.83 \\
\hline Short Core E & 8.00 & Short Core E & 6.30 \\
\hline Long Core B & 13.20 & Long Core A & 7.96 \\
\hline Long Core C & 9.42 & Long Core B & 9.21 \\
\hline Long Core D & 7.39 & Long Core C & 11.28 \\
\hline \multicolumn{4}{|c|}{ West Howland } \\
\hline Short Core A & 5.24 & & \\
\hline Short Core B & 7.47 & & \\
\hline Short Core C & 5.83 & & \\
\hline Short Core D & 5.72 & & \\
\hline Short Core E & 5.71 & & \\
\hline Long Core A & 7.24 & & \\
\hline Long Core B & 5.18 & & \\
\hline Long Core F & 6.14 & & \\
\hline \multicolumn{2}{|c|}{ West Maiana } & \multicolumn{2}{|c|}{ East Maiana } \\
\hline Short Core C & 5.22 & Short Core B & 7.00 \\
\hline Short Core D & 4.63 & Short Core C & 5.66 \\
\hline Short Core E & 4.93 & Short Core D & 5.27 \\
\hline Short Core F & 5.01 & Short Core E & 5.51 \\
\hline Short Core G & 4.35 & Short Core F & 4.75 \\
\hline Long Core A & 4.94 & Long Core A & 5.23 \\
\hline Long Core B & 5.89 & & \\
\hline Long Core H & 5.06 & & \\
\hline Long Core I & 6.04 & & \\
\hline Long Core J & 4.80 & & \\
\hline
\end{tabular}

Table C.1: Tissue thickness measurements from coral core samples collected from west and east sides of central equatorial Pacific islands in September 2012. 


\section{C.2 Water Chemistry Samples from 2012 Equatorial Pacific Sea Dragon Expedition}

\begin{tabular}{|c|c|c|c|c|c|c|c|c|c|c|c|}
\hline $\begin{array}{l}\text { Date } \\
\text { Sampled }\end{array}$ & $\begin{array}{c}\text { Depth } \\
\text { (meters) }\end{array}$ & $\begin{array}{c}\text { GPS } \\
\text { (latitude) }\end{array}$ & $\begin{array}{c}\text { GPS } \\
\text { (longitude) }\end{array}$ & $\begin{array}{l}\text { Temp. } \\
\left({ }^{\circ} \mathrm{C}\right)\end{array}$ & $\begin{array}{l}\text { Sal. } \\
\text { (psu) }\end{array}$ & $\begin{array}{c}\text { Alk. } \\
\left(\mu \text { eq } \mathbf{k g}^{-1}\right)\end{array}$ & $\begin{array}{c}\text { DIC } \\
\left(\mu \mathrm{mol} \mathrm{kg}^{-1}\right)\end{array}$ & $\begin{array}{l}{\left[\mathrm{NH}_{4}{ }^{+}\right]} \\
(\mu \mathrm{M})\end{array}$ & $\begin{array}{l}\left.\mathrm{SiO}_{4}\right] \\
(\mu \mathrm{M})\end{array}$ & $\begin{array}{l}{\left[\mathrm{PO}_{4}{ }^{3-}\right.} \\
(\mu \mathrm{M})\end{array}$ & $\begin{array}{l}\left.-+\mathrm{NO}_{3}{ }^{2-}\right] \\
(\mu \mathrm{M})\end{array}$ \\
\hline \multicolumn{12}{|c|}{ Transit Hydrocasts } \\
\hline \multirow{4}{*}{ Sept-7 } & 0 & $2^{\circ} 00.36 \mathrm{~N}$ & $157^{\circ} 43.82 \mathrm{~W}$ & 28.3 & 35.3 & 2321.8 & 2021.5 & 4.0 & 2.3 & 0.3 & 3.8 \\
\hline & 150 & $2^{\circ} 00.36 \mathrm{~N}$ & $157^{\circ} 43.82 \mathrm{~W}$ & 14.2 & 34.7 & 2294.3 & 2142.0 & 2.7 & 18.9 & 1.3 & 18.4 \\
\hline & 50 & $2^{\circ} 00.36 \mathrm{~N}$ & $157^{\circ} 43.82 \mathrm{~W}$ & 28.2 & 35.3 & 2327.0 & 2017.2 & 0.1 & 2.7 & 0.1 & 2.9 \\
\hline & 100 & $2^{\circ} 00.38 \mathrm{~N}$ & $157^{\circ} 43.83 \mathrm{~W}$ & 28.0 & 35.3 & 2323.2 & 2019.0 & 3.5 & 2.6 & 0.1 & 3.4 \\
\hline \multirow{4}{*}{ Sept-8 } & 0 & $1^{\circ} 00.16 \mathrm{~S}$ & $157^{\circ} 45.02 \mathrm{~W}$ & 28.0 & 35.5 & 2339.9 & 2037.3 & 2.3 & 2.4 & 0.3 & 4.0 \\
\hline & 50 & $1^{\circ} 00.16 \mathrm{~S}$ & $157^{\circ} 45.02 \mathrm{~W}$ & 28.0 & 35.5 & 2340.6 & 2025.4 & 1.7 & 3.4 & 0.2 & 4.0 \\
\hline & 100 & $1^{\circ} 00.16 \mathrm{~S}$ & $157^{\circ} 45.02 \mathrm{~W}$ & 27.8 & 35.5 & 2331.0 & 2047.3 & 1.3 & 2.4 & 0.3 & 4.3 \\
\hline & 150 & $1^{\circ} 00.16 \mathrm{~S}$ & $157^{\circ} 45.02 \mathrm{~W}$ & 25.5 & 35.9 & 2354.7 & 2114.6 & 1.5 & 3.4 & 0.7 & 8.6 \\
\hline \multirow{4}{*}{ Sept-9 } & 150 & $0^{\circ} 00.14 \mathrm{~N}$ & $157^{\circ} 45.16 \mathrm{~W}$ & 25.1 & 35.5 & 2328.0 & 2056.0 & 1.5 & 3.2 & 0.2 & 5.9 \\
\hline & 0 & $0^{\circ} 00.03 \mathrm{~S}$ & $157^{\circ} 45.75 \mathrm{~W}$ & 27.4 & 35.5 & 2328.5 & 2036.7 & 2.4 & 2.2 & 0.1 & 4.0 \\
\hline & 100 & $0^{\circ} 00.14 \mathrm{~N}$ & $157^{\circ} 45.16 \mathrm{~W}$ & 27.2 & 35.4 & 2323.1 & 2043.0 & 3.8 & 3.0 & 0.9 & 5.7 \\
\hline & 50 & $0^{\circ} 00.14 \mathrm{~N}$ & $157^{\circ} 45.16 \mathrm{~W}$ & 27.5 & 35.5 & 2316.6 & 2042.5 & 1.2 & 2.7 & 0.1 & 4.5 \\
\hline \multirow{4}{*}{ Sept-9 } & 0 & $1^{\circ} 00.33 \mathrm{~N}$ & $157^{\circ} 44.97 \mathrm{~W}$ & 27.7 & 35.3 & 2311.7 & 2050.7 & 0.8 & 2.6 & 0.2 & 3.9 \\
\hline & 50 & $1^{\circ} 00.33 \mathrm{~N}$ & $157^{\circ} 44.97 \mathrm{~W}$ & 27.5 & 35.3 & 2313.4 & 2031.3 & 1.1 & 3.0 & 0.2 & 3.9 \\
\hline & 100 & $1^{\circ} 00.33 \mathrm{~N}$ & $157^{\circ} 44.97 \mathrm{~W}$ & 27.0 & 35.1 & 2303.1 & 2054.3 & $<0.05$ & 4.1 & 0.4 & 6.7 \\
\hline & 150 & $1^{\circ} 00.33 \mathrm{~N}$ & $157^{\circ} 44.97 \mathrm{~W}$ & 22.7 & 34.8 & 2298.3 & 2097.4 & 0.4 & 9.8 & 0.7 & 11.4 \\
\hline \multirow{4}{*}{ Sept-18 } & 0 & $1^{\circ} 33.00 \mathrm{~N}$ & $165^{\circ} 00.11 \mathrm{~W}$ & 28.9 & 35.2 & 2307.4 & 2004.4 & 6.0 & 2.1 & 0.2 & 2.4 \\
\hline & 50 & $1^{\circ} 33.00 \mathrm{~N}$ & $165^{\circ} 00.11 \mathrm{~W}$ & 28.7 & 35.2 & 2299.8 & 2005.6 & 2.5 & 1.9 & $<0.05$ & 2.0 \\
\hline & 100 & $1^{\circ} 33.00 \mathrm{~N}$ & $165^{\circ} 00.11 \mathrm{~W}$ & 27.6 & 35.3 & 2307.2 & 2036.8 & 0.2 & 2.9 & 0.2 & 5.0 \\
\hline & 150 & $1^{\circ} 33.00 \mathrm{~N}$ & $165^{\circ} 00.11 \mathrm{~W}$ & 25.1 & 35.0 & 2304.9 & 2072.1 & 1.4 & 5.4 & 0.4 & 7.9 \\
\hline
\end{tabular}


2012 Sea Dragon water chemistry, continued

\begin{tabular}{|c|c|c|c|c|c|c|c|c|c|c|c|}
\hline $\begin{array}{c}\text { Date } \\
\text { Sampled }\end{array}$ & $\begin{array}{c}\text { Depth } \\
\text { (meters) }\end{array}$ & $\begin{array}{c}\text { GPS } \\
\text { (latitude) }\end{array}$ & $\begin{array}{c}\text { GPS } \\
\text { (longitude) }\end{array}$ & $\begin{array}{c}\text { Temp. } \\
\left({ }^{\circ} \mathrm{C}\right)\end{array}$ & $\begin{array}{l}\text { Sal. } \\
\text { (psu) }\end{array}$ & $\begin{array}{c}\text { Alk. } \\
\left(\mu \text { eq } \mathrm{kg}^{-1}\right)\end{array}$ & $\begin{array}{c}\text { DIC } \\
\left(\mu \mathrm{mol} \mathrm{kg}^{-1}\right)\end{array}$ & $\begin{array}{c}{\left[\mathrm{NH}_{4}{ }^{+}\right]} \\
(\mu \mathrm{M})\end{array}$ & $\begin{array}{l}{\left[\mathrm{SiO}_{4}\right]} \\
(\mu \mathrm{M})\end{array}$ & $\begin{array}{l}{\left[\mathrm{PO}_{4}{ }^{3-}\right.} \\
(\mu \mathrm{M})\end{array}$ & $\begin{array}{l}\left.1-+\mathrm{NO}_{3}{ }^{2-}\right] \\
(\mu \mathrm{M})\end{array}$ \\
\hline \multirow{4}{*}{ Sept-20 } & 0 & $0^{\circ} 59.96 \mathrm{~N}$ & $169^{\circ} 59.47 \mathrm{~W}$ & 28.1 & 35.2 & 2305.8 & 2025.5 & 0.9 & 2.7 & 0.1 & 3.0 \\
\hline & 50 & $0^{\circ} 59.96 \mathrm{~N}$ & $169^{\circ} 59.47 \mathrm{~W}$ & 28.1 & 35.2 & 2300.3 & 2015.0 & 0.3 & 2.5 & 0.1 & 3.2 \\
\hline & 100 & $0^{\circ} 59.96 \mathrm{~N}$ & $169^{\circ} 59.47 \mathrm{~W}$ & 27.0 & 35.2 & 2302.6 & 2035.8 & 1.2 & 3.1 & 0.2 & 5.4 \\
\hline & 150 & $0^{\circ} 59.96 \mathrm{~N}$ & $169^{\circ} 59.47 \mathrm{~W}$ & 22.3 & 35.1 & 2312.8 & 2084.1 & 0.1 & 6.4 & 0.5 & 8.6 \\
\hline \multirow{3}{*}{ Sept-25 } & 50 & $0^{\circ} 59.84 \mathrm{~N}$ & $178^{\circ} 33.64 \mathrm{~W}$ & & 35.2 & 2310.2 & 1998.3 & 1.3 & 2.0 & 0.2 & 2.0 \\
\hline & 100 & $0^{\circ} 59.84 \mathrm{~N}$ & $178^{\circ} 33.64 \mathrm{~W}$ & & 35.4 & 2312.7 & 2026.7 & 0.8 & 2.9 & $<0.05$ & 4.3 \\
\hline & 150 & $0^{\circ} 59.84 \mathrm{~N}$ & $178^{\circ} 33.64 \mathrm{~W}$ & & 35.3 & 2316.4 & 2074.4 & 0.6 & 4.6 & 0.2 & 7.7 \\
\hline \multirow{3}{*}{ Oct-2 } & 0 & $1^{\circ} 00.7601 \mathrm{~N}$ & $172^{\circ} 46.4032 \mathrm{E}$ & 27.5 & 35.4 & 2321.9 & 2054.2 & $<0.05$ & 3.1 & 0.1 & 6.6 \\
\hline & 50 & $1^{\circ} 00.7601 \mathrm{~N}$ & $172^{\circ} 46.4032 \mathrm{E}$ & 29.9 & 35.3 & 2311.2 & 1996.2 & $<0.05$ & 1.8 & $<0.05$ & 0.1 \\
\hline & 150 & $1^{\circ} 00.7601 \mathrm{~N}$ & $172^{\circ} 46.4032 \mathrm{E}$ & 23.9 & 35.3 & 2318.2 & 2089.7 & 0.4 & 1.7 & $<0.05$ & $<0.05$ \\
\hline \multicolumn{12}{|c|}{ East Jarvis } \\
\hline \multirow{4}{*}{ Sept-13 } & 0 & $0^{\circ} 22.27 \mathrm{~S}$ & $159^{\circ} 56.22 \mathrm{~W}$ & 27.7 & 35.5 & 2335.5 & 2035.3 & 2.7 & 2.7 & 0.2 & 4.4 \\
\hline & 50 & $0^{\circ} 22.27 \mathrm{~S}$ & $159^{\circ} 56.22 \mathrm{~W}$ & 27.6 & 35.5 & 2325.0 & 2041.4 & 5.7 & 2.6 & 1.4 & 4.8 \\
\hline & 100 & $0^{\circ} 22.27 \mathrm{~S}$ & $159^{\circ} 56.22 \mathrm{~W}$ & 29.2 & 35.5 & 2325.1 & 2063.8 & 2.0 & 2.7 & 0.3 & 5.2 \\
\hline & 150 & $0^{\circ} 22.27 \mathrm{~S}$ & $159^{\circ} 56.22 \mathrm{~W}$ & 18.4 & 35.3 & 2325.8 & 2151.0 & 0.9 & 9.1 & 0.9 & 14.2 \\
\hline \multirow{2}{*}{ Sept-14 } & $17(\mathrm{ft})$ & $0^{\circ} 22.287 \mathrm{~S}$ & $159^{\circ} 58.935 \mathrm{~W}$ & 28.4 & 35.5 & 2319.1 & 2031.3 & 5.1 & 2.6 & 0.6 & 5.8 \\
\hline & $15(\mathrm{ft})$ & $0^{\circ} 22.436 \mathrm{~S}$ & $159^{\circ} 59.004 \mathrm{~W}$ & 28.0 & 35.5 & 2316.7 & 2024.4 & 1.1 & 2.6 & 0.2 & 4.9 \\
\hline \multicolumn{12}{|c|}{ West Jarvis } \\
\hline \multirow[t]{2}{*}{ Sept-15 } & $61(\mathrm{ft})$ & $0^{\circ} 22.134 \mathrm{~S}$ & $160^{\circ} 00.487 \mathrm{~W}$ & 27.8 & 35.6 & 2314.6 & 2043.0 & 1.1 & 7.9 & 0.3 & 5.0 \\
\hline & $39(\mathrm{ft})$ & $0^{\circ} 22.149 \mathrm{~S}$ & $160^{\circ} 00.500 \mathrm{~W}$ & 27.6 & 35.6 & 2327.0 & 2043.5 & 2.2 & 3.6 & 0.1 & 5.0 \\
\hline
\end{tabular}


2012 Sea Dragon water chemistry, continued

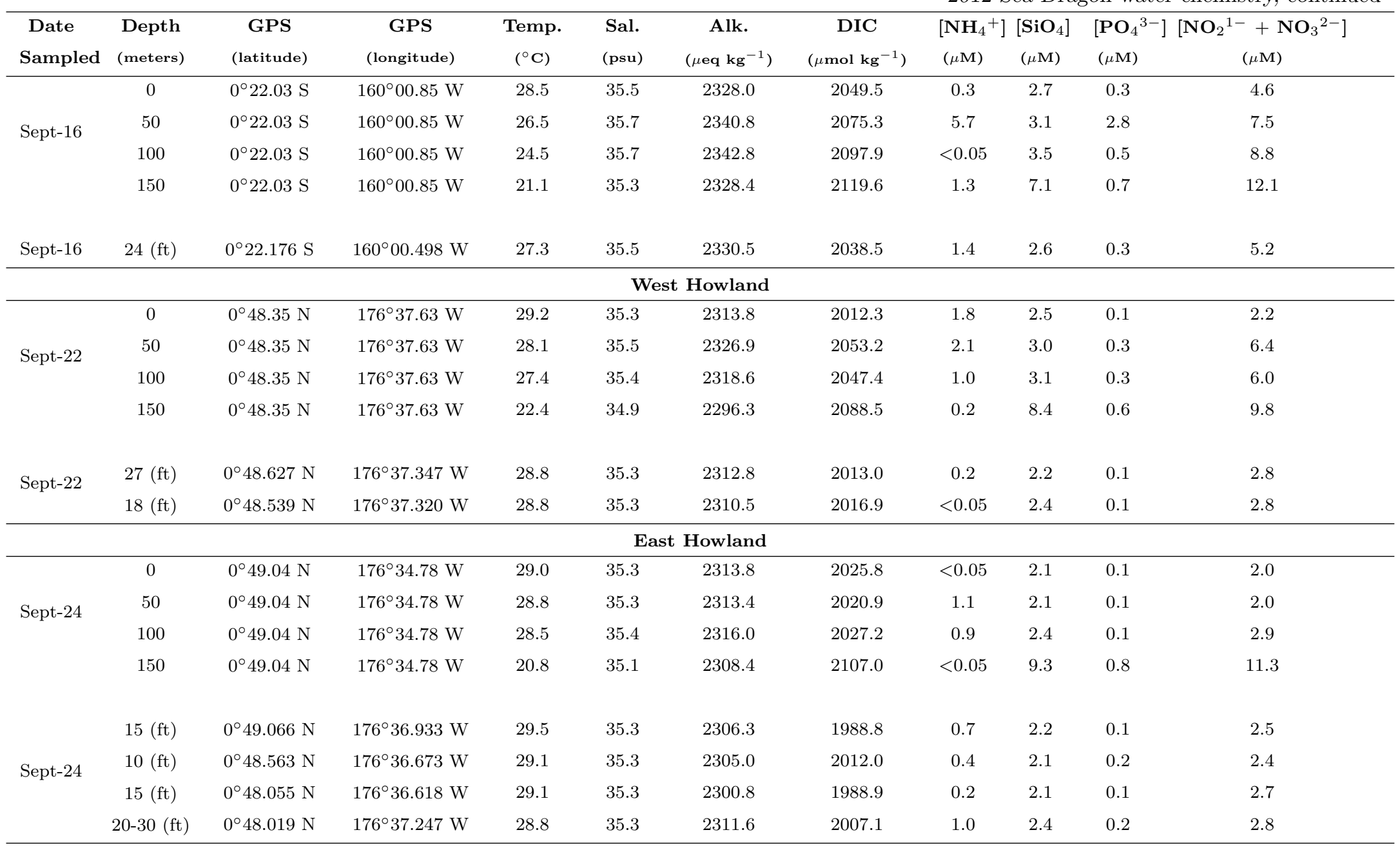


2012 Sea Dragon water chemistry, continued

\begin{tabular}{|c|c|c|c|c|c|c|c|c|c|c|c|}
\hline $\begin{array}{c}\text { Date } \\
\text { Sampled }\end{array}$ & $\begin{array}{l}\text { Depth } \\
\text { (meters) }\end{array}$ & $\begin{array}{c}\text { GPS } \\
\text { (latitude) }\end{array}$ & $\begin{array}{c}\text { GPS } \\
\text { (longitude) }\end{array}$ & $\begin{array}{c}\text { Temp. } \\
\left({ }^{\circ} \mathrm{C}\right)\end{array}$ & $\begin{array}{l}\text { Sal. } \\
\text { (psu) }\end{array}$ & $\begin{array}{c}\text { Alk. } \\
\left(\mu \text { eq } \mathbf{k g}^{-1}\right)\end{array}$ & $\begin{array}{c}\text { DIC } \\
\left(\mu \mathrm{mol} \mathrm{kg}^{-1}\right)\end{array}$ & $\begin{array}{l}{\left[\mathrm{NH}_{4}{ }^{+}\right]} \\
(\mu \mathrm{M})\end{array}$ & $\begin{array}{l}{\left[\mathrm{SiO}_{4}\right]} \\
(\mu \mathrm{M})\end{array}$ & $\begin{array}{l}{\left[\mathbf{P O}_{4}{ }^{3-}\right]} \\
(\mu \mathrm{M})\end{array}$ & $\begin{array}{c}{\left[\mathbf{N O}_{2}{ }^{1-}+\mathbf{N O}_{3}{ }^{2-}\right]} \\
(\mu \mathrm{M})\end{array}$ \\
\hline \multicolumn{12}{|c|}{ East Maiana } \\
\hline \multirow{4}{*}{ Sept-29 } & 0 & $0^{\circ} 57.1104 \mathrm{~N}$ & $173^{\circ} 06.6104 \mathrm{E}$ & 30.3 & 34.7 & 2272.7 & 1955.1 & 0.2 & 1.8 & 0.2 & $<0.05$ \\
\hline & 50 & $0^{\circ} 57.1104 \mathrm{~N}$ & $173^{\circ} 06.6104 \mathrm{E}$ & 29.9 & 35.4 & 2316.9 & 1983.3 & 3.3 & 1.6 & 0.2 & 1.0 \\
\hline & 100 & $0^{\circ} 57.1104 \mathrm{~N}$ & $173^{\circ} 06.6104 \mathrm{E}$ & 28.6 & 35.4 & 2315.6 & 2027.0 & 2.7 & 1.7 & 0.2 & 0.9 \\
\hline & 150 & $0^{\circ} 57.1104 \mathrm{~N}$ & $173^{\circ} 06.6104 \mathrm{E}$ & 22.7 & 35.3 & 2318.6 & 2094.5 & 2.5 & 1.6 & 0.2 & 0.2 \\
\hline \multirow{4}{*}{ Oct-1 } & $20-30(\mathrm{ft})$ & $0^{\circ} 57.981 \mathrm{~N}$ & $173^{\circ} 04.449 \mathrm{E}$ & 30.4 & 34.9 & 2259.6 & 1945.0 & 0.2 & 1.8 & 0.2 & $<0.05$ \\
\hline & $20-30(\mathrm{ft})$ & $0^{\circ} 55.990 \mathrm{~N}$ & $173^{\circ} 02.371 \mathrm{E}$ & 30.5 & 34.8 & 2255.9 & 1944.8 & 3.3 & 1.6 & 0.2 & 1.0 \\
\hline & $20-30(\mathrm{ft})$ & $0^{\circ} 53.991 \mathrm{~N}$ & $173^{\circ} 01.436 \mathrm{E}$ & 30.2 & 35.4 & 2267.0 & 1964.1 & 2.7 & 1.7 & 0.2 & 0.9 \\
\hline & $20-30(\mathrm{ft})$ & $0^{\circ} 51.995 \mathrm{~N}$ & $173^{\circ} 00.674 \mathrm{E}$ & 30.2 & 34.8 & 2279.0 & 1947.7 & 2.5 & 1.6 & 0.2 & 0.2 \\
\hline \multicolumn{12}{|c|}{ West Maiana } \\
\hline Sept-29 & $13(\mathrm{ft})$ & $1^{\circ} 00.428 \mathrm{~N}$ & $172^{\circ} 58.962 \mathrm{E}$ & 30.1 & 35.0 & 2271.1 & 1952.0 & $<0.05$ & 2.0 & 0.1 & 0.3 \\
\hline \multirow{2}{*}{ Sept-30 } & $6(\mathrm{ft})$ & $1^{\circ} 00.413 \mathrm{~N}$ & $172^{\circ} 58.976 \mathrm{E}$ & & 34.7 & 2055.4 & 1766.5 & 2.1 & 3.1 & 0.1 & 1.0 \\
\hline & $14(\mathrm{ft})$ & $1^{\circ} 00.443 \mathrm{~N}$ & $172^{\circ} 58.952 \mathrm{E}$ & & 34.7 & 2043.7 & 1792.5 & $<0.05$ & 3.1 & $<0.05$ & 0.5 \\
\hline \multirow{4}{*}{ Sept-30 } & 0 & $0^{\circ} 59.5656 \mathrm{~N}$ & $172^{\circ} 66.5345 \mathrm{E}$ & 30.6 & 35.0 & 2293.5 & 1963.7 & $<0.05$ & 2.6 & 0.2 & $<0.05$ \\
\hline & 50 & $0^{\circ} 59.5656 \mathrm{~N}$ & $172^{\circ} 66.5345 \mathrm{E}$ & 29.9 & 35.4 & 2311.2 & 1988.6 & 0.6 & 1.9 & 0.1 & $<0.05$ \\
\hline & 100 & $0^{\circ} 59.5656 \mathrm{~N}$ & $172^{\circ} 66.5345 \mathrm{E}$ & 29.3 & 35.4 & 2314.7 & 2010.3 & 4.0 & 3.1 & 1.0 & 2.6 \\
\hline & 150 & $0^{\circ} 59.5656 \mathrm{~N}$ & $172^{\circ} 66.5345 \mathrm{E}$ & 25.8 & 35.6 & 2328.1 & 2070.2 & 0.3 & 3.3 & 0.4 & 7.2 \\
\hline \multirow{2}{*}{ Sept-30 } & $23.9(\mathrm{ft})$ & $0^{\circ} 57.856 \mathrm{~N}$ & $172^{\circ} 57.705 \mathrm{E}$ & 30.2 & 35.1 & 2239.3 & 1936.5 & 0.2 & 2.1 & 0.1 & 0.3 \\
\hline & $18(\mathrm{ft})$ & $0^{\circ} 56.748 \mathrm{~N}$ & $172^{\circ} 56.841 \mathrm{E}$ & 29.8 & 35.3 & 2272.7 & 1983.1 & 0.2 & 2.1 & 0.1 & 0.4 \\
\hline \multirow{2}{*}{ Oct-1 } & $28(\mathrm{ft})$ & $0^{\circ} 59.121 \mathrm{~N}$ & $172^{\circ} 57.970 \mathrm{E}$ & 29.7 & 35.1 & 2206.7 & 1957.3 & $<0.05$ & 2.0 & 0.2 & 0.5 \\
\hline & $7(\mathrm{ft})$ & $0^{\circ} 57.209 \mathrm{~N}$ & $172^{\circ} 57.309 \mathrm{E}$ & 30.2 & 35.0 & 2118.6 & 1877.8 & 1.1 & 2.2 & 0.1 & 1.1 \\
\hline
\end{tabular}


Table C.2: Results from chemical analyses of seawater samples collected from and around central equatorial Pacific islands. The collection date, depth and GPS location (latitude and longitude) are given for each sample, in addition to in situ temperature, measured salinity (Sal.), Alkaliniy (Alk.), dissolved inorganic carbon (DIC) and nutrient concentrations. Water samples were collected using Niskin bottles and temperatures measured using Onset Hoboß Loggeres that were either tethered to a line or sitting in close proximity to coral sampling sites 